\title{
1994 Site Environmental Report Sandia National Laboratories Albuquerque, New Mexico
}

a. 201995

Prepared by

Sandia National Laboratories?

Albuquerque, New Mexice* 185 and Livermore, California 94550

for the United States. 8 gipartment of Energy

under Contract DE-AC04:94AL85000

Approved for public rélease; distribution on suniminted."

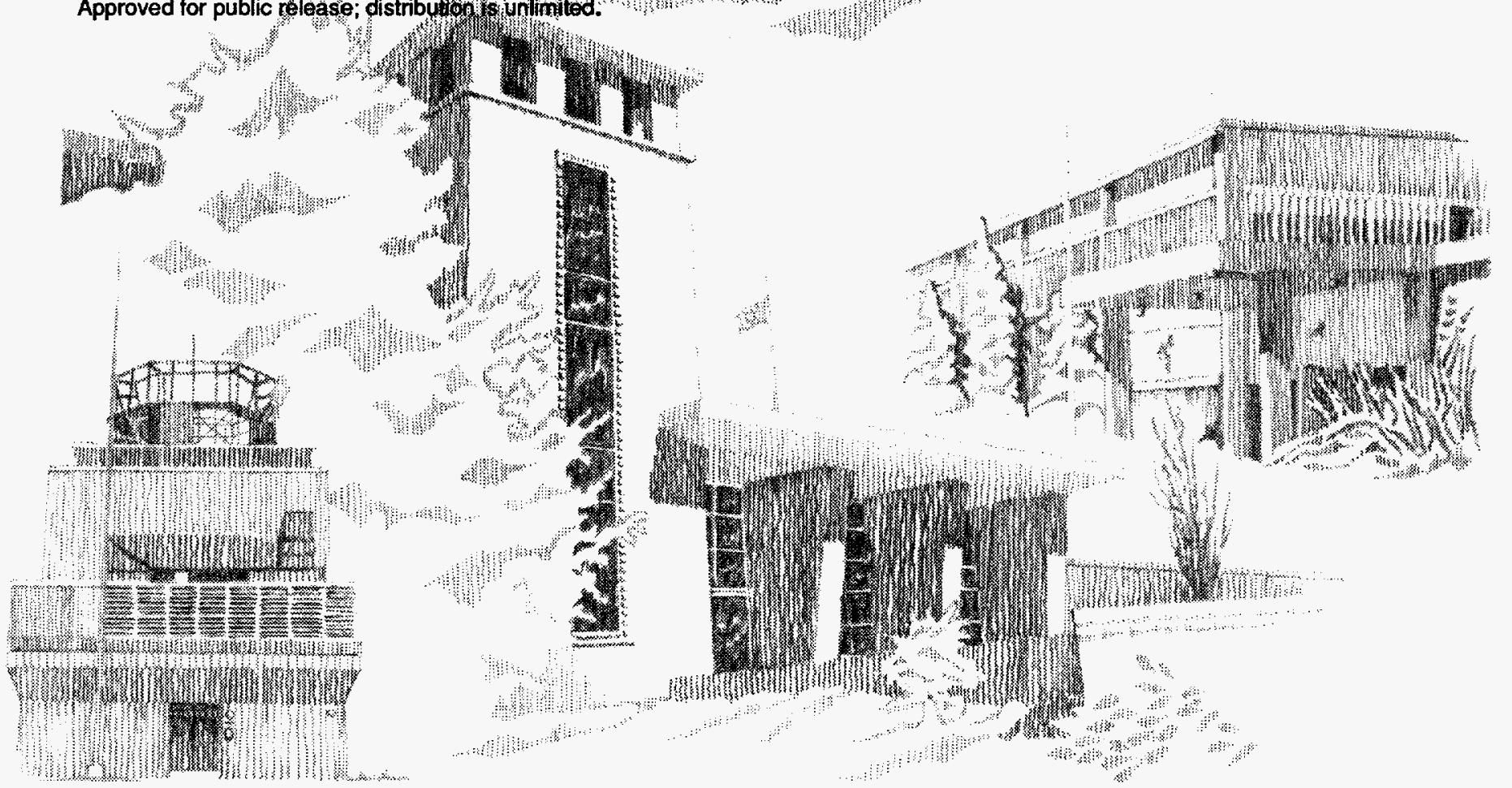


Issued by Sandia National Laboratories, operated for the United States Department of Energy by Sandia Corporation.

NOTICE: This report was prepared as an account of work sponsored by an agency of the United States Government. Neither the United States Government nor any agency thereof, nor any of their employees, nor any of their contractors, subcontractors, or their employees, makes any warranty, express or implied, or assumes any legal liability or responsibility for the accuracy, completeness, or usefulness of any information, apparatus, product, or process disclosed, or represents that its use would not infringe privately owned rights. Reference herein to any specific commercial product, process, or service by trade name, trademark, manufacturer, or otherwise, does not necessarily constitute or imply its endorsement, recommendation, or favoring by the United States Government, any agency thereof or any of their contractors or subcontractors. The views and opinions expressed herein do not necessarily state or reflect those of the United States Government, any agency thereof or any of their contractors.

Printed in the United States of America. This report has been reproduced directly from the best available copy.

Available to DOE and DOE contractors from Office of Scientific and Technical Information PO Box 62

Oak Ridge, TN 37831

Prices available from (615) 576-8401, FTS 626-8401

Available to the public from

National Technical Information Service

US Department of Commerce

5285 Port Royal Rd

Springfield, VA 22161

NTIS price codes

Printed copy: A07

Microfiche copy: A01 


\section{DISCLAIMER}

Portions of this document may be illegible in electronic image products. Images are produced from the best available original document. 
SAND95-1953

Distribution

Unlimited Release

Printed September 1995

Category UC-630

\title{
1994 SITE ENVIRONMENTAL REPORT SANDIA NATIONAL LABORATORIES ALBUQUERQUE, NEW MEXICO
}

\author{
7500 Environmental Operations Center \\ Sandia National Laboratories \\ Albuquerque, NM 87185
}

\author{
Lih-Jenn Shyr, ${ }^{*}$ Editor \\ Tami Wiggins, ${ }^{\dagger}$ Associate Editor \\ Brenda Bailey White, ${ }^{\ddagger}$ Technical Editor \\ Rebecca Sanchez, ${ }^{\ddagger}$ Technical Word Processor
}

\begin{abstract}
This 1994 report contains data from routine radiological and nonradiological environmental monitoring activities. Summaries of significant environmental compliance programs in progress, such as National Environmental Policy Act documentation, environmental permits, environmental restoration, and various waste management programs for Sandia National Laboratories in Albuquerque, New Mexico, are included. The maximum off-site dose impact from air emissions was calculated to be $1.5 \times 10^{-4}$ millirem. The total population within a 50-mile radius of Sandia National Laboratories/New Mexico received an estimated collective dose of 0.012 person-rem during 1994 from the laboratories' operations. This report is prepared for the U.S. Department of Energy in compliance with DOE Order 5400.1.
\end{abstract}

\footnotetext{
*Air Quality Department, Sandia National Laboratories
}

†Keystone Environmental \& Planning, Inc.

${ }^{\ddagger}$ Creative Computer Services

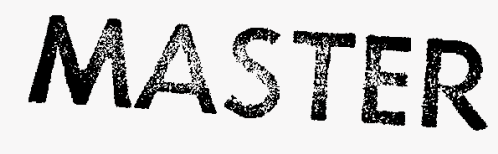




\section{CONTRIBUTORS/AUTHORS}

Author

J. Bonaguidi

T. Culp

C. Davis

R. Deola

B. Doremus

N. Durand

S. Edmund

C. Fink

F. Ghanbari

B. Hamilton

J. Jarry

A. Jones

F. Lauffer

\section{Section}

\section{3, Surface Discharge Program}

5.5, Assessment of Potential Dose to the Public

5.6, Summary of the 1994 On-Site and Off-Site Dose Impacts Appendix H, 1994 Environmental Compliance Activities at the Kauai Test Facility

\subsection{7, Pollution Prevention Program}

1.3, Climate and Meteorology

5.1, Meteorological Monitoring Program

5.2, Ambient Air Surveillance Program

Appendix A, Meteorological Data

2.1.1, CERCLA/SARA

2.1.2, RCRA, Environmental Restoration Project

2.3.2, Chemical Waste Landfill

3.1, Environmental Restoration Project

Appendix B, SNL/NM Environmental Restoration Project Sites

8.0, QA Programs

Appendix D, Sample Collection and Analysis

Appendix F, Quality Assurance Data

2.5, DOE Tiger Team Assessment Summary

3.2, UST Management

3.3, SPCC Plan

6.2, Storm Water Program

5.3, Air Emissions Radiation Monitoring

5.4, Air Quality Radiological Monitoring Results

\subsection{3, Mixed Waste}

2.4, Environmental Permits

2.1.5, Clean Water Act

2.1.6, Safe Drinking Water Act

2.4, Environmental Permits

6.1, Waste-Water Programs

Appendix D, Sample Collection and Analysis

1.4 , Geology

1.5, Hydrology

7.0, Groundwater Monitoring

Appendix D, Sample Collection and Analysis

Appendix G, Environmental Regulations and Standards 
M. Lincoln

Y. McClellan

M. du Mond

D. Moore

P. Peterson

C. Pigg

C. Roma

L.-J. Shyr

B. Suderman

B. Stone

D. Szklarz

S. Tyhurst

T. Wolff
2.1.2, RCRA, Mixed Waste Management

2.3.5, Mixed Waste Authority

3.4.2, Radioactive Waste

4.1, Surveillance Locations

4.2, Sample Collection and Analysis

4.4 Terrestrial Nonradiological Surveillance Results

2.1.4, Clean Air Act

2.3.1, Air Quality Compliance

2.4, Environmental Permits

3.6.1, Summary of Release Reporting

5.7, Air Quality Management

\subsection{1, Hazardous Waste and RCRA}

3.4.4, Special-Case Waste

2.1.8, FIFRA

2.1.2, RCRA, Hazardous Waste Management

2.3.3, LDRs and TCLPs

2.3.4, Hazardous Waste Fees

Executive Summary

4.1, Surveillance Locations

4.2, Sample Collection and Analysis

4.3, Terrestrial Radiological Surveillance Results

Appendix D, Sample Collection and Analysis

Appendix E, Minimum Detection Limits

Appendix F, Quality Assurance Data

Appendix G, Environmental Regulations and Standards

Appendix H, 1994 Environmental Compliance Activities at the Kauai Test Facility

3.4.6, Asbestos Waste

2.1.1, CERCLA/SARA

2.1.7, TSCA

3.4.5, PCB Waste

3.6.1, Summary of Release Reporting

2.1.3, NEPA

2.1.9, Endangered Species Act

2.1.10, Cultural Resources Act

2.1.11, Executive Orders

3.5, NEPA Compliance/Documentation in 1994

Appendix C, NEPA Documentation

Appendix H, 1994 Environmental ComplianceActivities at the Kauai Test Facility 


\section{ACKNOWLEDGMENTS}

This 1994 report was compiled by the staff of the Environmental Operations Center (7500) of Sandia National Laboratories/New Mexico (SNL/NM).

\section{NOTES TO THE READER}

If you have comments cr questions about this report, or need further information, contact:

Sandia National Laboratories

Media Relations Dept.

MS 0167

P.O. Box 5800

Albuquerque, NM 87185

(505) $844-4207$ or

(505) $844-2282$ 


\section{CONTENTS}

$\underline{\text { Page }}$

EXECUTIVE SUMMARY $\ldots \ldots \ldots \ldots \ldots \ldots \ldots \ldots$ ES-1

1.0 INTRODUCTION $\ldots \ldots \ldots \ldots \ldots \ldots \ldots \ldots \ldots \ldots \ldots \ldots \ldots \ldots$

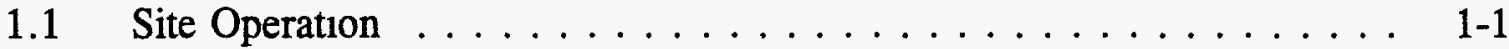

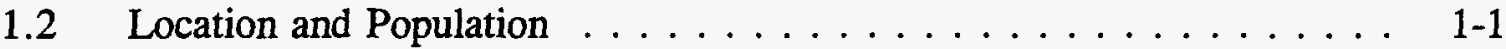

1.3 Climate and Meteorology $\ldots \ldots \ldots \ldots \ldots \ldots \ldots$. . . . . . . . . . .

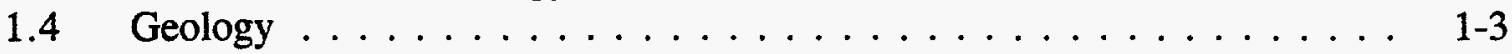

1.5 Hydrology . . . . . . . . . . . . . . . . . . 1-5

1.6 Biology . . . . . . . . . . . . . . . . 1-7

1.7 Technical Areas . . . . . . . . . . . . . . . . . . 1-7

1.8 Remote Test Areas . . . . . . . . . . . . . . . . 1-10

2.0 COMPLIANCE SUMMARY $\ldots \ldots \ldots \ldots \ldots \ldots \ldots \ldots \ldots \ldots \ldots \ldots$

2.1 Compliance Regulations $\ldots \ldots \ldots \ldots \ldots \ldots$ 2-1

2.1.1 Comprehensive Environmental Response, Compensation and Liability Act . . . . . . . . . . . . . . 2-1

2.1.2 Resource Conservation and Recovery Act . . . . . . . . 2-1

2.1.3 National Environmental Policy Act ... . . . . . 2-3

2.1 .4 Clean Air Act $\ldots \ldots \ldots \ldots \ldots \ldots \ldots . \ldots \ldots$

2.1 .5 Clean Water Act . . . . . . . . . . 2-5

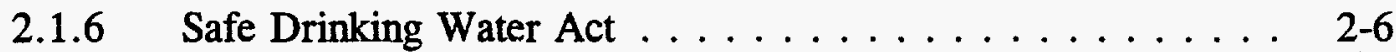

2.1.7 Toxic Substances Control Act . . . . . . . . . . 2-6

2.1.8 Federal Insecticide, Fungicide, and Rodenticide Act . . . . 2-7

2.1.9 Endangered Species Act . . . . . . . . . . . 2-7

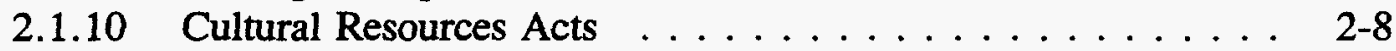

2.1 .11 Executive Orders $\ldots \ldots \ldots \ldots \ldots \ldots \ldots \ldots \ldots$ 2-8

2.21994 Audits and Appraisals $\ldots \ldots \ldots \ldots \ldots \ldots \ldots \ldots \ldots \ldots . \ldots \ldots$

2.3 Current Issues and Actions $\ldots \ldots \ldots \ldots \ldots \ldots \ldots \ldots \ldots . \ldots \ldots$

2.3.1 Air Quality Compliance $\ldots \ldots \ldots \ldots \ldots \ldots$. . . . . . . . . . . . . . . .

2.3.2 Chemical Waste Landfill . . . . . . . . . . . . . 2-10

2.3.3 Landfill Disposal Restrictions and Toxicity

2.3.4 Hazardous Waste Fees . . . . . . . . . . . . . . 2-10

2.3.5 Mixed Waste Authority . . . . . . . . . 2-11 


\section{CONTENTS}

(Continued)

Page

$2.4 \quad$ Environmental Permits . . . . . . . . . . . . . . . 2-11

2.5 U.S. Department of Energy Tiger Team Assessment

Summary .......................... 2-11

3.0 ENVIRONMENTAL PROGRAMS INFORMATION . . . . . . . . . . . . . 3-1

3.1 Environmental Restoration Project ................. 3-1

3.2 Underground Storage Tank Management . . . . . . . . . . . . . 3-2

3.3 Spill Prevention Control and Countermeasures Plan . . . . . . . . . . . 3-2

3.4 Waste Management Programs .................. 3-3

3.4.1 Hazardous Waste and the Resource Conservation and

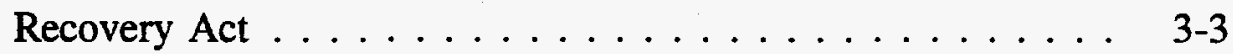

3.4 .2 Radioactive Waste ................... 3-5

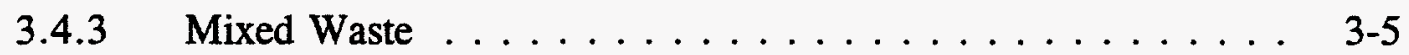

3.4.4 Special-Case Waste ..................... 3-6

3.4.5 Polychlorinated Biphenyl Waste ............. 3-7

3.4 .6 Asbestos Waste . . . . . . . . . . . . . . 3-7

3.4.7 Pollution Prevention Program ............ 3-7

3.5 National Environmental Policy Act Compliance

Activities and Documentation in $1994 \ldots \ldots \ldots$. . . . . . . . . . .

3.5.1 1994 Activities ........................ 3-10

3.5.2 NEPA Training and Outreach .................. 3-12

3.5.3 NEPA Baseline Information .............. 3-12

3.5.4 Environmental Assessment Findings of No $3-12$

3.6 Summary of 1994 Release and Environmental Incident Reports . . . . . 3-13

3.6.1 Summary of Release Reporting . . . . . . . . . . . . . . 3-13

3.6.2 Environmental Occurrence Reporting ............ 3-14

4.0 TERRESTRIAL SURVEILLANCE $\ldots \ldots \ldots \ldots \ldots \ldots \ldots \ldots$. . . . . . . . .

4.1 Surveillance Locations . . . . . . . . . . . . . . . . 4-1

4.2 Sample Collection and Analysis . . . . . . . . . . . . . . . . 4-1

4.3 Terrestrial Radiological Surveillance Results . . . . . . . . . . . . 4-6 


\section{CONTENTS}

(Continued)

$\underline{\text { Page }}$

4.3.1 Vegetation . . . . . . . . . . . . . . 4-7

4.3.2 Soil . . . . . . . . . . . . . . . 4-8

4.3.3 Surface Water . . . . . . . . . . . . . . 4-10

4.3.4 Sediment . . . . . . . . . . . . . . . . . . 4-10

4.3.5 Environmental Thermoluminescent Dosimeters . . . . . . . 4 4-10

4.4 Terrestrial Nonradiological Surveillance Results . . . . . . . . . . . 4-16

$4.4 .1 \quad$ Soil . . . . . . . . . . . . . . . . . 4-17

4.4.2 Surface Water $\ldots \ldots \ldots \ldots \ldots \ldots \ldots \ldots \ldots$ 4-21

\subsection{AIR QUALITY SURVEILLANCE AND EMISSIONS}

MONITORING

5.1 Meteorological Monitoring Program $\ldots \ldots \ldots \ldots \ldots$ 5-1

5.1.1 Meteorological Monitoring Results . . . . . . . . . 5-1

5.2 Ambient Air Surveillance Program $\ldots \ldots \ldots \ldots \ldots \ldots$ 5-7

5.2.1 Ambient Air Monitoring Results $\ldots \ldots \ldots \ldots \ldots$. . . . . .

5.2.1.1 Criteria Pollutants . . . . . . . . . . . . . . . 5-9

5.2.1.2 Particulate Matter Metals Analyses . . . . . . . 5- 5-10

5.2.1.3 Volatile Organic Compounds . . . . . . . . . 5-10

5.3 Air Emissions Radiological Monitoring $\ldots \ldots \ldots \ldots \ldots$. . . . . . .

5.3.1 Radioactive Effluent Monitoring . . . . . . . . . . 5-13

5.3 .2 Technical Area $V$ Reactors . . . . . . . . . . . . 5-13

5.3 .3 Technical Area IV Facility $\ldots \ldots \ldots \ldots \ldots \ldots$. . . . . . . .

5.4 Air Quality Radiological Monitoring Results . . . . . . . . . . . . 5 5-17

5.5 Assessment of Potential Dose to the Public . . . . . . . . . . . 5-17

5.5.1 Air Emission Sources $\ldots \ldots \ldots \ldots \ldots \ldots \ldots$. . . . . . . . .

5.5 .2 Public Receptors . . . . . . . . . . . . . . . 5-18

5.5 .3 Meteorological Data . . . . . . . . . . . . . 5-18

5.5 .4 Demographic Data . . . . . . . . . . . . . . . . 5-18

5.5.5 Results of the Dose Assessment . . . . . . . . . . . . . . 5-20

5.5.6 Population Dose at Kirtland Air Force Base . . . . . . . . 5 5-20

5.5.7 Population Dose for the 50-Mile Radius . . . . . . . . . . 5-24 
CONTENTS

(Continued)

$\underline{\text { Page }}$

5.6 Summary of the 1994 On-Site and Off-Site Dose Impacts . . . . . . . 5-24

5.7 Air Quality Management . . . . . . . . . . . . . . . . . . 5-24

5.7.1 Air Quality Regulations . . . . . . . . . . . . . 5-24

5.7.2 Airborne Emissions and Permits . . . . . . . . . 5-26

5.7.3 Criteria Pollutants Inventory . . . . . . . . . . 5-27

5.7.4 Inventory and Assessment of Hazardous Air

6.0 WATER MONITORING PROGRAMS $\ldots \ldots \ldots \ldots \ldots \ldots$ 6-1

6.1 Waste-Water Programs $\ldots \ldots \ldots \ldots \ldots \ldots \ldots \ldots$ 6-1

6.1.1 Discharges to Publicly Owned Treatment Works . . . . . . . . 6-1

6.1 .2 Summary of Monitoring Results $\ldots \ldots \ldots \ldots \ldots \ldots$ 6-2

6.2 Storm Water Program . . . . . . . . . . . . . . . . . 6 6-7

6.3 Surface Discharge Program $\ldots \ldots \ldots \ldots \ldots \ldots \ldots$ 6-7

7.0 GROUNDWATER MONITORING $\ldots \ldots \ldots \ldots \ldots \ldots \ldots \ldots$

7.1 Regulatory Requirements . . . . . . . . . . . . . . 7-1

7.2 The SNL/NM Groundwater Monitoring Well Network . . . . . . 7 7-2

7.3 Water Level Measurements . . . . . . . . . . . . 7-3

7.3.1 Production Well Pumping $\ldots \ldots \ldots \ldots \ldots \ldots$ 7-5

7.3.2 Monitor Well Hydrographs . . . . . . . . . . . 7-5

7.3.2.1 Chemical Waste Landfill . . . . . . . . . . . 7-5

7.3.2.2 Mixed Waste Landfill ... . . . . . . . . 7-9

7.3.2.3 Other Technical Area III Wells . . . . . . . . . . 7-9

7.3.2.4 South Fence Road . . . . . . . . . . . . 7-9

7.3.2.5 East of the Fault Zone . . . . . . . . . 7-13

7.3.2.6 KAFB Sanitary Lagoon . . . . . . . . . . 7-13

7.3.2.7 Tijeras Arroyo . . . . . . . . . . . 7-13

7.3.2.8 Golf Course . . . . . . . . . . . . . . 7-13

7.3.2.9 Technical Area II Water Level Measurements . . . . 7-13

7.3.3 Potentiometric Surface $\ldots \ldots \ldots \ldots \ldots \ldots$. . . . . . . 


\section{CONTENTS}

(Continued)

Page

7.4 Groundwater Quality ................... 7-17

7.4.1 Groundwater Sampling . . . . . . . . . . . . . . 7-19

7.4.2 Sampling Procedures and Methods ............. 7-19

7.4.3 Groundwater Surveillance Results . . . . . . . . . . . . . 7-20

7.4.3.1 Volatile Organic Compounds . . . . . . . . 7-20

7.4.3.2 Inorganic Compounds and Phenolics ...... 7-20

7.4 .3 .3 Metals ................... 7-21

7.4.3.4 Gamma-Emitting Radionuclide Screening . . . . . . 7-21

7.4.3.5 Isotopic Radionuclide and Tritium Analyses .................. 7-21

7.4.4 Chemical Waste Landfill Assessment Monitoring Results . . . . 7-21

7.4.4.1 Volatile Organic Compounds .......... . 7-21

7.4 .4 .2 Metals .................. 7-23

7.4.5 Mixed Waste Landfill Monitoring Results . . . . . . . . . . . 7-24

7.4.6 Liquid Waste Disposal System Monitoring Results . . . . . . 7-24

7.4.7 Technical Area II Groundwater Monitoring Results . . . . . . . 7-25

8.0 QUALITY ASSURANCE PROGRAMS . . . . . . . . . . . . . . . 8-1

8.1 Quality Assurance Policies and Responsibilities

for Environmental Programs . . . . . . . . . . . . . . . . 8 8-1

8.2 Quality Assurance of Environmental Sampling and Analysis ....................... 8-1

8.2.1 Quality Assurance for Sampling Programs . . . . . . . . . . 8-1

8.2.2 Quality Assurance for Analytical Programs .......... 8-2

8.2.3 Data Review and Validation .............. 8-4

8.3 Contractor Quality Assurance Overview . . . . . . . . . . . . . 8-4 


\section{CONTENTS}

(Concluded)

$\underline{\text { Page }}$

9.0 REFERENCES . . . . . . . . . . . . . . . . . . 9-1

APPENDIX A Meteorological Data . . . . . . . . . . . . . . . A-1

APPENDIX B Sandia National Laboratories/New Mexico Environmental

Restoration Project Sites . . . . . . . . . . . . . . B B-1

APPENDIX C National Environmental Policy Act Documentation . . . . . . . . C -1

APPENDIX D Sample Collection and Analysis $\ldots \ldots \ldots \ldots \ldots \ldots \ldots$ D-1

APPENDIX E Minimum Detection Limits $\ldots \ldots \ldots \ldots \ldots \ldots$ E-1

APPENDIX F Quality Assurance Data . . . . . . . . . . . . F

APPENDIX G Environmental Regulations and Standards . . . . . . . . . . G-1

APPENDIX H 1994 Environmental Compliance Activities at the

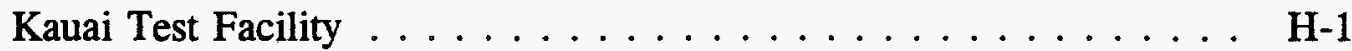




\section{FIGURES}

Page

1-1 Albuquerque Site Regional Setting . . . . . . . . . . . . . 1-2

1-2 Albuquerque Basin of North Central New Mexico . . . . . . . . . . . . . 1-4

1-3 Generalized Geology in the Vicinity of SNL/NM and KAFB . . . . . . . 1-6

1-4 Mesa Vegetation . . . . . . . . . . . . . . . . . . . . 1-8

1-5 Manzano Foothills Vegetation . . . . . . . . . . . . . . . . . 1-8

1-6 SNL/NM Technical Areas I through $\mathrm{V}$ and Remote Areas . . . . . . . . . 1-9

3-1 Process for Creating and Reviewing U.S. Department of

Energy National Environmental Policy Act Documentation . . . . . . . . . 3-11

4-1 On-Site and Perimeter Terrestrial Monitoring Locations . . . . . . . . . . . . 4-2

4-2 Off-Site Terrestrial Monitoring Locations . . . . . . . . . . . . . . . . . 4 4-3

4-3 Perimeter Soil Locations with Increasing Total Uranium Over Time . . . . . . 4 4-11

4-4 SNL/NM Soil Locations with Increasing Total Uranium Over Time . . . . . . 4-12

4-5 SNL/NM Soil Location 6 with Increasing Cesium-137 Over Time . . . . . . . 4-13

4-6 Mean Thermoluminescent Dosimeter Dose Estimate by Year . . . . . . . . 4-18

5-1 Meteorological Monitoring Station Locations . . . . . . . . . . . . . . . 5-2

5-2 Annual Wind Roses for Towers CL1, A36, and SC1 . . . . . . . . . 5-5

5-3 Day and Night Wind Frequency Distributions for Tower A36 . . . . . . . 5 5-6

5-4 Ambient Air Monitoring Station Locations, SNL/NM . . . . . . . . . . . 5-8

5-5 Summary of Atmospheric Releases of Argon-41, Tritium, Krypton-85, and Xenon-135 From SNL/NM Facilities Since $1978 \ldots \ldots$. . . 5-16

5-6 Facilities at SNL/NM Reporting Radionuclide Air Releases in 1994 . . . . . . . . . . . . . . . . . . . . . . . . . . . . . . 5-19

5-7 Off-Site and Boundary Receptor Locations Around SNL/NM . . . . . . . 5-23

6-1 SNL/NM Waste-Water Monitoring Station Locations $\ldots \ldots \ldots \ldots$. . . . . . . 6

7-1 Locations of Sandia National Laboratories and Kirtland Air Force Base Wells and Springs . . . . . . . . . . . . . . . . 7 7-4

7-2 Water Pumped from Kirtland Air Force Base Production Wells, 1994 . . . . . 7-6

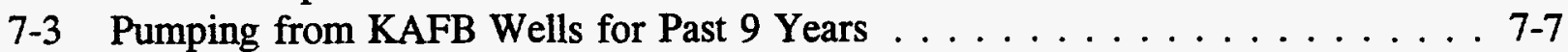

7-4 Water Pumped from Five KAFB Production Wells $\ldots \ldots \ldots \ldots \ldots . .7$. . . . . .

7-5 Hydrographs for the CWL Since $1985 \ldots \ldots \ldots \ldots \ldots \ldots \ldots$. $\ldots \ldots \ldots$

7-6 Hydrographs for the MWL Since $1989 \ldots \ldots \ldots \ldots$. . . . . . . . . 7-11

7-7 Hydrographs for Other Technical Area III Wells since $1989 \ldots \ldots \ldots \ldots$. . . . . . .

7-8 Historical Water Level Trends . . . . . . . . . . . . . . . . . . 7-14

7-9 Hydrographs for Tijeras Arroyo Wells Since $1991 \ldots \ldots \ldots \ldots$. . . . . . . . . .

7-10 Hydrographs of Golf Course Wells Since $1991 \ldots \ldots \ldots$. . . . . . . . 7-16

7-11 KAFB Potentiometric Surface Map, July $1994 \ldots \ldots \ldots \ldots$. . . . . . . . . . 


\section{TABLES}

$\underline{\text { Page }}$

2-1 1994 Audits and Appraisals . . . . . . . . . . . . . . . . . . . . . . 2-9

2-2 Summary of Environmental Permits and Registrations . . . . . . . . . . . . 2-12

2-3 Status of SNL/NM Corrective Actions . . . . . . . . . . . . . . 2-15

3-1 EPA-Permitted SNL/NM Hazardous Waste Transporters Used in Calendar Year $1994 \ldots \ldots$. . . . . . . . . . . . . . . . . . . . . . .

3-2 Waste Disposal Facilities Used by SNL/NM in Calendar Year $1994 \ldots \ldots \ldots \ldots \ldots$. . . . . . . . . . . . . . . . . . . . . . . . . . . . . .

3-3 Annual Summary of 1994 Reportable Quantity Accidental Release Reporting . . . . . . . . . . . . . . . . . . 3-14

4-1 SNL/NM Terrestrial Surveillance Locations and Sample Types . . . . . . . . . 4-4

4-2 Summary Statistics for Concentrations of Tritium in Vegetation, May $1994 \ldots \ldots \ldots \ldots \ldots \ldots \ldots$. . . . . . . . . . . . . . . . . . . . .

4-3 Summary Statistics for Concentrations of Tritium in Vegetation, August $1994 \ldots \ldots \ldots$. . . . . . . . . . . . . . . . . . . . . . . 4-8

4-4 Summary Statistics for Concentrations of Soil Radionuclides,

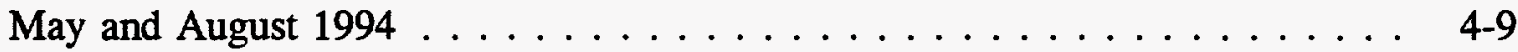

4-5 Concentrations of Surface-Water Radionuclides, May 1994 . . . . . . . . . . . 4-14

4-6 Concentrations of Surface-Water Radionuclides, August $1994 \ldots$. . . . . . . . 4-15

4-7 Concentrations of Sediment Radionuclides, May and August 1994 . . . . . . . 4-16

4-8 Summary of Thermoluminescent Dosimeter Measurements for 1994 . . . . . 4 4-17

4-9 Summary of Metal Concentrations in Soil and Sediment Samples . . . . . . . . 4-19

4-10 Metal Concentration Differences Between Off-Site and Other

Sample Groups . . . . . . . . . . . . . . . . . . . . . 4-22

5-1 Annual Summary Information from Tower A36 . . . . . . . . . . . . 5-3

5-2 Tower A36 Stability Class Frequency Distribution . . . . . . . . . . . . . 5-7

5-3 Criteria Pollutant Standards and SNL/NM Monitoring Results . . . . . . . . . . 5-9

$5-4 \quad \mathrm{PM}_{10}$ Sample Analyses Conducted in $1994 \ldots \ldots \ldots \ldots$. . . . . . . . . . . 5-10

5-5 Composited Results for the $\mathrm{PM}_{10}$ Network . . . . . . . . . . . . . . . . . . . 5-11

5-6 Results for VOCs Observed Most Frequently at SNL/NM . . . . . . . . . . 5 5-12

5-7 Summary of Radionuclide Releases for $1994 \ldots \ldots$. . . . . . . . . . . . . . 5-14

5-8 Annual Effective Dose Equivalent to Off-Site and Boundary Receptors ... . . . . . . . . . . . . . . . 5-21

5-9 Annual Effective Dose Equivalent to Kirtland Air Force Base On-Site Receptors . . . . . . . . . . . . . . . . . . . . 5 5-22 


\section{TABLES \\ (Concluded)}

$\underline{\text { Page }}$

5-10 Summary of Off-Site Dose Impacts in Comparison to the National Emission Standards for Hazardous Air Pollutants and to Natural

Background Radiation ..................... . . . . . . . . . . . . . . . . .

5-11 1994 Criteria Pollutant Inventory $\ldots \ldots \ldots \ldots \ldots \ldots \ldots \ldots \ldots$

5-12 1994 Emergency Generator Emissions Estimates . . . . . . . . . . . . . . . . 5-29

5-13 Summary of Significant Laboratory-Wide Chemical Usage . . . . . . . . . . 5-30

6-1 SNL/NM Waste-Water Discharge Permits, Sample Locations,

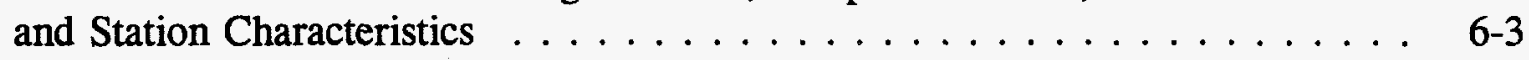

6-2 Summary of Concentration Violations $\ldots \ldots \ldots \ldots \ldots$. . . . . . . .

7-1 Groundwater Monitoring Sampling Frequency . . . . . . . . . . . . . 7-3

7-2 Summary of Groundwater Surveillance Metals Results Above MCLs . . . . . . 7-22

7-3 Summary of Chemical Waste Landfill Groundwater Sampling for VOCs . . . 7-23

7-4 Summary of Chemical Waste Landfill Groundwater Sampling for Metals . . . . 7-24

7-5 Summary of TA-II Groundwater Radionuclide Analyses . . . . . . . . . . 7-25 


\section{ABBREVIATIONS}

\section{Units}

\begin{tabular}{ll}
$\mathrm{ac}$ & acre \\
$\mathrm{cf}$ & cubic feet \\
${ }^{\circ} \mathrm{C}$ & Celsius degree \\
$\mathrm{cm}$ & centimeter \\
$\mathrm{cm} / \mathrm{yr}$ & centimeters per year \\
${ }^{\circ} \mathrm{F}$ & Fahrenheit degree \\
$\mathrm{famsl}$ & feet above mean sea level \\
$\mathrm{fbgs}$ & feet below ground surface \\
$\mathrm{fbtoc}$ & feet below top of casing \\
$\mathrm{ft}$ & foot \\
$\mathrm{ft}$ & square foot \\
$\mathrm{ft}^{3}$ & cubic foot \\
$\mathrm{g}$ & gram \\
$\mathrm{gpd}$ & gallons per day \\
$\mathrm{gal}$. & gallon \\
$\mathrm{gpm}$ & gallons per minute \\
$\mathrm{ha}$ & hectare \\
$\mathrm{hr}$ & hour \\
in. & inch \\
$\mathrm{in} . / \mathrm{yr}$ & inches per year \\
$\mathrm{J}$ & Joule \\
$\mathrm{kg}$ & kilogram \\
$\mathrm{km}$ & kilometer \\
$\mathrm{km}$ & square kilometer \\
$\mathrm{kW}$ & kilowatt \\
$\mathrm{L}$ & liter \\
$\mathrm{lb}$ & pound \\
$\mathrm{lb} / \mathrm{yr}$ & pounds per year \\
& \\
\hline
\end{tabular}

\begin{tabular}{ll}
$\mathrm{lps}$ & liters per second \\
$\mu$ & micron \\
$\mathrm{m}$ & meter \\
$\mathrm{m}^{2}$ & square meter \\
$\mathrm{MBtu} / \mathrm{hr}$ & $\begin{array}{l}\text { million British thermal } \\
\text { units per hour }\end{array}$ \\
$\mathrm{MJ}$ & megajoule \\
$\mathrm{meq} / \mathrm{L}$ & milliequivalents per liter \\
$\mathrm{m} / \mathrm{s}$ & meters per second \\
$\mu \mathrm{m} / \mathrm{m}^{3}$ & micrograms per cubic \\
$\mathrm{mg} / \mathrm{L}$ & meter \\
$\mu \mathrm{mho} / \mathrm{cm}$ & milligrams per liter \\
$\mathrm{mho}$ & micromhos per centimeter, \\
$\mathrm{mi}$ & unit of specific conductance \\
$\mathrm{mi}$ & unit of conductance \\
$\mathrm{mph}$ & mile \\
$\mathrm{min}$ & square mile \\
$\mathrm{mL}$ & miles per hour \\
$\mathrm{ppb}$ & minute \\
$\mathrm{ppm}$ & milliliter \\
$\mathrm{qt}$ & parts per billion \\
$\mathrm{s}$ & parts per million \\
$\mathrm{scf}$ & quart \\
$\mathrm{yd}$ & second \\
$\mathrm{yr}$ & standard cubic feet \\
$\%$ & square yard \\
& year \\
\hline moisture & weight percent of water \\
&
\end{tabular}




\section{ABBREVIATIONS \\ (Continued)}

Abbreviations for Referenced Nuclides and Components

$\begin{array}{llll}\mathrm{Ag} & \text { silver } & \mathrm{Kr}-88 & \text { krypton-88 } \\ \mathrm{Al} & \text { aluminum } & \mathrm{Li} & \text { lithium } \\ \mathrm{Am}-241 & \text { americium-241 } & \mathrm{LiF} & \text { lithium fluoride } \\ \mathrm{Ar} & \text { argon } & \mathrm{Mg} & \text { magnesium } \\ \mathrm{Ar}-41 & \text { argon-41 } & \mathrm{Mn} & \text { manganese } \\ \mathrm{As} & \text { arsenic } & \mathrm{Na} & \text { sodium } \\ \mathrm{Ba} & \text { barium } & \mathrm{Ni} & \text { nickel } \\ \mathrm{Be} & \text { beryllium } & \mathrm{N}-13 & \text { nitrogen-13 } \\ \mathrm{C}-13 & \text { carbon-13 } & \mathrm{N}-15 & \text { nitrogen-15 } \\ \mathrm{Ca} & \text { calcium } & \mathrm{O} & \text { oxygen } \\ \mathrm{Cd} & \text { cadmium } & \mathrm{O}-15 & \text { oxygen-15 } \\ \mathrm{Cs} & \text { cesium } & \mathrm{O}-18 & \text { oxygen-18 } \\ \mathrm{Cs}-137 & \text { cesium-137 } & \mathrm{Pb} & \text { lead } \\ \mathrm{Cr} & \text { chromium } & \mathrm{Pb}-212 & \text { lead-212 } \\ \mathrm{Co} & \text { cobalt } & \mathrm{Pu} & \text { plutonium } \\ \mathrm{Co}-60 & \text { cobalt-60 } & \mathrm{Pu}-241 & \text { plutonium-241 } \\ \mathrm{Cu} & \text { copper } & \mathrm{Po}-210 & \text { polonium-210 } \\ \mathrm{D} & \text { deuterium } & \mathrm{Ra}-226 & \text { radium-226 } \\ \mathrm{DU} & \text { depleted uranium } & \mathrm{Ra}-228 & \text { radium-228 } \\ \mathrm{I}-129 & \text { iodine-129 } & \mathrm{Rb}-88 & \text { rubidium-88 } \\ \mathrm{Fe} & \text { iron } & \mathrm{S} & \text { sulphur } \\ \mathrm{Fe}-55 & \text { iron-55 } & \mathrm{Se} & \text { selenium } \\ \mathrm{Gd} & \text { gadolinium } & \mathrm{Sr}-90 & \text { strontium-90 } \\ \mathrm{Ge} & \text { germanium } & \mathrm{Th} & \text { thorium } \\ \mathrm{H}-3 & \text { tritium } & \mathrm{U} & \text { uranium } \\ \mathrm{Hg} & \text { mercury } & \mathrm{U} & \text { total uranium } \\ \mathrm{HT} & \text { tritiated hydrogen } & \mathrm{U}-238 & \text { uranium-238 } \\ \mathrm{HTO} & \text { tritiated water vapor } & \mathrm{V} & \text { vanadium } \\ \mathrm{K} & \text { potassium } & \mathrm{Xe} & \text { xenon } \\ \mathrm{K}-40 & \text { potassium-40 } & \mathrm{Xe}-133 & \text { xenon-133 } \\ \mathrm{Kr} & \text { krypton } & \mathrm{Xe}-135 & \text { xenon-135 } \\ \mathrm{Kr}-85 & \text { krypton-85 } & \mathrm{Xe}-135 \mathrm{~m} \text { xenon-135m } \\ \mathrm{Kr}-85 \mathrm{~m} & \text { krypton-85m } & \mathrm{Zn} & \text { zinc } \\ \mathrm{Kr}-87 & \text { krypton-87 } & & \\ & & & \\ & & & \end{array}$

\section{$\underline{\text { Radioactivity Measurements }}$}

Beq $/ \mathrm{kg} \quad$ Becquerels per kilogram

$\mathrm{Beq} / \mathrm{L} \quad$ Becquerels per liter 


\section{ABBREVIATIONS \\ (Continued)}

$\mathrm{Ci}$

EDE

$\mu \mathrm{Ci}$

$\mu \mathrm{Ci} / \mathrm{MJ}$

$\mathrm{mR}$

mrem

$\mathrm{mrem} / \mathrm{yr}$

person-rem

pCi

$\mathrm{R}$

rem

Sv

Acronyms

$\mathrm{ABC} / \mathrm{AQCB}$

ACM

ACRR

ADM

ADS

AEC

AIP

AIRFA

AL/KAO

ALARA

AMPL

ANSI

AQCR

AR

AR/COC

ARAR

ARPA

AWN

BDM

BSS

BSW

BW

CA

CAA

CAAA

CAM curie (unit of radioactivity)

effective dose equivalent

microcurie

microcuries per megajoule

milliroentgen (unit of radiation exposure)

millirem (unit of radiation dose)

millirem per year

radiation dose to population (also man-rem)

picocurie

roentgen (unit of radiation exposure)

roentgen equivalent man (amount of ionizing radiation

required to produce the same biological effect as $1 \mathrm{R}$ of

high-penetration X-rays)

sievert (unit of radiation dosage, $\sim 8.38 \mathrm{R}$ )

Albuquerque/Bernalillo County Air Quality Control Board asbestos-containing material

Annular Core Research Reactor

Action Description Memorandum

Activity Data Sheet

Atomic Energy Commission

Agreement-in-Principle

American Indian Religious Freedom Act

Albuquerque/Kirtland Area Office

as low as reasonably achievable

Advanced Manufacturing Processes Laboratory

American National Standards Institute

Air Quality Control Regulation

averaged replicate

Analysis Request/Chain of Custody Form

applicable or relevant and appropriate requirements

Archaeological Resources Protection Act

acid waste neutralization

Braddock, Dunn, and McDonald

Burn Site Spring

Burn Site Well

background well

Corrective Action

Clean Air Act

Clean Air Act Amendments

continuous air monitor 


\section{ABBREVIATIONS \\ (Continued)}

\section{Acronyms}

\begin{tabular}{|c|c|}
\hline CAN & Clean Air Network \\
\hline CB2 & Chemical Waste Landfill (TA-3) background well \#CWL-BW2 \\
\hline CDX & countermeasures demonstration experiment \\
\hline CEQ & Council on Environmental Quality \\
\hline CERCLA & $\begin{array}{l}\text { Comprehensive Environmental Response, Compensation and } \\
\text { Liability Act }\end{array}$ \\
\hline CERF & Civil Engineer Research Facility \\
\hline CFC & chlorofluorocarbon \\
\hline CFR & Code of Federal Regulations \\
\hline $\mathrm{CO}$ & carbon monoxide \\
\hline $\mathrm{CO}_{2}$ & carbon dioxide \\
\hline CPMS & Criteria Pollutant Monitoring Station \\
\hline $\mathrm{CV}$ & coefficient of variation \\
\hline CWA & Clean Water Act \\
\hline CWL & Chemical Waste Landfill \\
\hline CWL-MW & Chemical Waste Landfill-Monitoring Well \\
\hline CX & categorial exclusion \\
\hline CY & calendar year \\
\hline CYS & Coyote Spring \\
\hline $\mathrm{DA}$ & decision amount \\
\hline DCG & derived concentration guide \\
\hline DNA & Defense Nuclear Agency \\
\hline DOC & U.S. Department of Commerce \\
\hline DOD & U.S. Department of Defense \\
\hline DOE & U.S. Department of Energy \\
\hline $\mathrm{DOE} / \mathrm{AL}$ & U.S. Department of Energy/Albuquerque \\
\hline DOE/ALO & U.S. Department of Energy/Albuquerque Operations Office \\
\hline DOE/EPD & U.S. Department of Energy/Environmental Protection Division \\
\hline DOE/HQ & U.S. Department of Energy/Headquarters \\
\hline $\mathrm{DOE} / \mathrm{KAO}$ & U.S. Department of Energy/Kirtland Area Office \\
\hline $\mathrm{DOE} / \mathrm{NV}$ & U.S. Department of Energy/Nevada Operations Office \\
\hline DOT & U.S. Department of Transportation \\
\hline DP & Discharge Plan \\
\hline DSTP & Draft Site Treatment Plan \\
\hline DQO & data quality objective \\
\hline EA & Environmental Assessment \\
\hline EB1 & Equipment Blank \#1 \\
\hline EB2 & Equipment Blank \#2 \\
\hline EBB & bailer equipment blank \\
\hline EBP1 & pump equipment blank \#1 \\
\hline EBP2 & pump equipment blank \#2 \\
\hline
\end{tabular}




\section{ABBREVIATIONS \\ (Continued)}

\section{Acronyms}

$\begin{array}{ll}\text { ECF } & \text { Explosives Components Facility } \\ \text { ECL } & \text { Environmental Checklist } \\ \text { EDE } & \text { effective dose equivalent } \\ \text { EG\&G } & \text { Edgerton, Germeshausen \& Grier Corporation } \\ \text { EIS } & \text { Environmental Impact Statement } \\ \text { EIS/EIR } & \text { Environmental Impact Statement/Environmental Impact Review } \\ \text { EIS/ODIS } & \begin{array}{l}\text { Effluent Information System/Onsite Discharge Information } \\ \text { System }\end{array} \\ \text { EMP } & \text { Environmental Monitoring Plan } \\ \text { ENCOTEC } & \text { Environmental Control Technology Corporation } \\ \text { ENVC } & \text { Environmental Operations Center } \\ \text { EO } & \text { Executive Order } \\ \text { EOC } & \text { Environmental Operations Center } \\ \text { EOD } & \text { explosive ordnance disposal } \\ \text { EORC } & \text { Environmental Operations Records Center } \\ \text { EPA } & \text { U.S. Environmental Protection Agency } \\ \text { EPCRA } & \text { Emergency Planning and Community Right-to-Know Act } \\ \text { EPD } & \text { Environmental Programs Departments } \\ \text { ER } & \text { Environmental Restoration } \\ \text { ESA } & \text { Endangered Species Act } \\ \text { ES\&H } & \text { Environment, Safety, and Health } \\ \text { FFCA } & \text { Federal Facility Compliance Act } \\ \text { FIFRA } & \text { Federal Insecticide, Fungicide, and Rodenticide Act } \\ \text { FONSI } & \text { Finding of No Significant Impact } \\ \text { FR } & \text { Federal Register } \\ \text { FY } & \text { fiscal year } \\ \text { GC } & \text { gas chromatography } \\ \text { GCS } & \text { Golf Course South Well } \\ \text { GFAA } & \text { graphite furnace atomic absorption } \\ \text { GSM } & \text { Greystone Manor Well } \\ \text { HAP } & \text { hazardous air pollutant } \\ \text { HBL } & \text { Hubbell Spring } \\ \text { HC } & \text { hydrocarbon } \\ \text { HCF } & \text { Hot Cell Facility } \\ \text { HCFC } & \text { hydrochlorofluorocarbon } \\ \text { HE } & \text { high explosives } \\ \text { HEPA } & \text { high-efficiency particulates in air } \\ \text { HERMES } & \text { High-Energy Radiation Megavolt Electron Source } \\ \text { HF } & \text { hydrofluoric acid } \\ \text { HIIIA } & \text { HERMES-III Accelerator } \\ & \end{array}$




\section{ABBREVIATIONS \\ (Continued)}

Acronyms

HIL

$\mathrm{HNO}_{3}$

$\mathrm{H}_{2} \mathrm{~S}$

HSWA

HWDMS

HWMF

IC

ICP

ID

IDP

IEEE

IRP

IT

IT/AS

ITRI

JT

K10

KAFB

KPMG

KTF

KUMSC

LANL

LATA

LCD

LCS

LDR

LECS

LF1

LF2

LIHE

LIWG

LLW

LMF

LWDS

MAC

MAP

MCA

MB1

MCL
EOD Hill Well duplicate sample

nitric acid

hydrogen sulfide

Hazardous and Solid Waste Amendments

Hazardous Waste Data Management System

Hazardous Waste Management Facility

Industrial Classification

inductively coupled plasma (method)

identification

Integrated Demonstration Program

Institute of Electrical and Electronics Engineers

Installation Restoration Program (KAFB)

International Technology Corporation

International Technology Corporation, Analytical Services

Inhalation Toxicology Research Institute

Just-in-Time

Kirtland Air Force Base Well \#KAFB10

Kirtland Air Force Base

Klenvled, Peat, Marwick, Goerdler Limited Liability

Partnership

Kauai Test Facility

Kirtland Underground Munitions Storage Complex

Los Alamos National Laboratory

Los Alamos Technical Associates

laboratory control duplicate

laboratory control samples

Land Disposal Restriction

Liquid Effluent Control System

Landfill Well \#LF/DM-01 (KAFB IRP Site)

Landfill Well \#LF/DM-02 (KAFB IRP Site)

light initiated high explosives

Line Implementation Working Group

low-level radioactive waste

Large-Scale Melt Facility

Liquid Waste Disposal System

maximum allowable concentration

Mitigation Action Plan

multichannel analyzer

Mixed Waste Landfill (TA-3) background well \#MWL-BW1 (SNL/NM

ER Site)

maximum contaminant level 


\section{ABBREVIATIONS \\ (Continued)}

Acronyms

MCLG

MEI

MDA

MDL

MDL

MinNet

MO

MOU

MS

MSDS

MSL

MTF

MVJ

MVK

MVX

MW

MWL

$\mathrm{N}$

NA

NAEP

$\mathrm{NaF}$

NBS

NC

NAAQS

NCC

NCP

ND

NE

NEPA

NESHAP

NFA

NG

NGTF

NHPA

NIOSH

NIST

NM

NM

maximum contaminant level goals

maximum exposed individual

minimum detectable activity

Microelectronics Development Laboratory

minimum detection level

Waste Minimization Network

mobile office

Memorandum of Understanding

mass spectrometry

Material Safety Data Sheet

Melting and Solidification Laboratory

memo-to-file

Tree Farm well \#MVMW-J (NMED Mountain View Monitoring Well)

Tree Farm well \#MVMW-K (NMED Mountain View Monitoring Well)

Tree Farm well \#MVMW-K duplicate sample

mixed waste

Mixed Waste Landfill

normal

not analyzed, not applicable, or not available

National Association of Environmental Professionals

sodium fluoride

National Bureau of Standards

not calculated or calculable

National Ambient Air Quality Standards

National Climatic Centers

National Oil and Hazardous Substances Pollution Contingency

Plan

analyte not detected at the MDL indicated

MCL not established

National Environmental Policy Act

National Emission Standards for Hazardous Air Pollutants

No Further Action

Neutron Generator

Neutron Generator Test Facility

National Historic Preservation Act

National Institute for Occupational Safety and Health

National Institute of Standards (formerly NBS)

New Mexico

parameter not measured this quarter 


\section{ABBREVIATIONS \\ (Continued)}

\section{Acronyms}

$\begin{array}{ll}\text { NMAQS } & \text { New Mexico Air Quality Standards } \\ \text { NMED } & \text { New Mexico Environment Department } \\ \text { NMEIB } & \text { New Mexico Environmental Improvement Board } \\ \text { NMHWMR } & \text { New Mexico Hazardous Waste Management Regulations } \\ \text { NMWQA } & \text { New Mexico Water Quality Authority } \\ \text { NMWQCC } & \text { New Mexico Water Quality Control Commission } \\ \text { NMWQR } & \text { New Mexico Water Quality Regulations } \\ \text { NO } & \text { nitrogen dioxide } \\ \text { NO } & \text { nitrogen oxides } \\ \text { NOAA } & \text { National Oceanographic and Atmospheric Administration } \\ \text { NOD } & \text { Notice of Deficiency } \\ \text { NOI } & \text { Notice of Intent (to Discharge) } \\ \text { NON } & \text { Notification of Noncompliance } \\ \text { NOV } & \text { Notice of Violation } \\ \text { NP } & \text { not performed } \\ \text { NPDES } & \text { National Pollutant Discharge Elimination System } \\ \text { NPL } & \text { National Priorities List } \\ \text { NPN } & \text { nitrate-plus-nitrite } \\ \text { NRC } & \text { National Response Center } \\ \text { NRC } & \text { U.S. Nuclear Regulatory Commission } \\ \text { NSPS } & \text { New Source Performance Standards } \\ \text { NS } & \text { not sampled during this quarter } \\ \text { NTS } & \text { Nevada Test Site } \\ \text { NTU } & \text { nephelometric turbidity unit } \\ \text { NW3 } & \text { Northwest TA-3 Well } \\ \text { O } & \text { ozone } \\ \text { ODS } & \text { ozone-depleting substance } \\ \text { OEL } & \text { Occupational Exposure Limit } \\ \text { OSHA } & \text { Occupational Safety and Health Administration } \\ \text { OSI } & \text { on-site investigation } \\ \text { OU } & \text { operable unit } \\ \text { PA } & \text { Preliminary Assessment } \\ \text { PA/SI } & \text { Preliminary Assessment/Site Inspection } \\ \text { PBFA-II } & \text { Particle Beam Fusion Accelerator-II } \\ \text { PCB } & \text { polychlorinated biphenyl } \\ \text { PDL } & \text { Process Development Laboratory } \\ \text { PDWR } & \text { Primary Drinking Water Regulations } \\ \text { PEIS } & \text { Programmatic Environmental Impact Statement } \\ \text { pH } & \\ \text { PM } & \text { particulate matter } \\ & \end{array}$




\section{ABBREVIATIONS \\ (Continued)}

Acronyms

$\begin{array}{ll}\text { PM }_{10} & \begin{array}{l}\text { respirable particulate matter (diameter equal to or less } \\ \text { than 10 microns) }\end{array} \\ \text { PMRF } & \text { Pacific Missile Range Facility } \\ \text { POM } & \text { point of measure } \\ \text { POTW } & \text { publicly-owned treatment works } \\ \text { PP } & \text { pollution prevention } \\ \text { PSD } & \text { Prevention of Significant Deterioration } \\ \text { PSTP } & \text { Proposed Site Treatment Plan } \\ \text { PWA } & \text { Process Waste Assessment } \\ \text { QA } & \text { quality assurance } \\ \text { QAP } & \text { Quality Assessment Program } \\ \text { QC } & \text { quality control } \\ \text { R\&D } & \text { research and development } \\ \text { RAM } & \text { radiological air monitor } \\ \text { RCRA } & \text { Resource Conservation and Recovery Act } \\ \text { RFA } & \text { RCRA Facility Assessment } \\ \text { RH } & \text { relative humidity } \\ \text { RLA } & \text { Recircling Linear Accelerator } \\ \text { RMAL } & \text { Rocky Mountain Analytical Laboratory } \\ \text { RMMA } & \text { Radioactive Material Management Area } \\ \text { RMSEL } & \text { Robotic Manufacturing Science and Engineering Laboratory } \\ \text { RMWMF } & \text { Radioactive and Mixed Waste Management Facility } \\ \text { ROD } & \text { Record of Decision } \\ \text { RPD } & \text { relative percent difference } \\ \text { RQ } & \text { reportable quantity } \\ \text { RSI } & \text { RCRA Site Investigation } \\ \text { SARA } & \text { Superfund Amendments and Reauthorization Act } \\ \text { SASN } & \text { silver acetylide-silver nitrate } \\ \text { SC } & \text { special-case (waste) } \\ \text { SC } & \text { specific conductance, in micromhos per centimeter } \\ \text { SC-COM } & \text { special case - commercially held, U.S. Department of Energy-owned } \\ & \text { materials } \\ \text { SC-GTCC } & \text { special case - U.S. Department of Energy comparable } \\ \text { greater-than-Class-C (waste) } \\ \text { SCH } & \text { Schoolhouse Well (SNL/NM ER Site) } \\ \text { SC-HLI } & \text { special case - high-level, incidental (waste) } \\ \text { SC-PAL } & \text { special case - performance assessment limiting (waste) } \\ \text { SC-TRU } & \text { special case - noncertifiable, nontransportable TRU (waste) } \\ \text { SC-US } & \text { special case - uncertified or uncharacterized (waste) } \\ \text { SDF } & \text { Strategic Defense Facility } \\ \text { SDI } & \text { Strategic Defense Initiative } \\ \text { SDIO } & \text { Strategic Defense Initiative Organization } \\ & \end{array}$




\section{ABBREVIATIONS \\ (Continued)}

Acronyms

SDWA

SFR

SIC

SIMS+

SMERF

SMO

SNL

SNL/CA

SNL/NM

$\mathrm{SO}_{2}$

SOP

SPCC

SPR-III

SSM

STAR

STARS

STF

STL

SU

SVOC

SW3

SWHC

SWMU

TA

TAL

TCA

TCE

TCL

TCLP

TCS

TDS

TEVES

TJE

TJX

TLD

TNMHC

TOC

TOF

TOX

TPH
Safe Drinking Water Act

South Fence Road

Standard Industrial Classification

Sandia Issues Management System

Smoke Emission Reduction Facility

Sample Management Office

Sandia National Laboratories

Sandia National Laboratories/California

Sandia National Laboratories/New Mexico

sulfur dioxide

Standard Operating Procedure

Spill Prevention Control and Countermeasures

Sandia Pulsed Reactor-III

Sol se Mete Spring

stability array (decks) or Sample Tracking Analytical Results

(database)

Strategic Targeting System

Simulated Test Facility

Simulation Technology Laboratory

standard units

semivolatile organic compound

Southwest TA-3 Well

Site-Wide Hydrogeologic Characterization Project

Solid Waste Management Unit

Technical Area

target analyte list

1,1,1-trichloroethane

trichloroethylene

target compound list

toxicity characteristic leaching procedure

Technical Support Center

total dissolved solids

Thermal Enhanced (soil) Vapor Extraction System

Tijeras East Well (KAFB IRP Site)

Tijeras East Well duplicate

thermoluminescent dosimeter

total non-methane hydrocarbon

total organic carbon

Time of Flight

total organic halogen

total petroleum hydrocarbons 


\section{ABBREVIATIONS \\ (Concluded)}

Acronyms

TRI

toxic release inventory

TRU

transuranic

TRUPACT

transuranic package transporter

TSCA

TSDF

TSP

TSS

TTCE

TTF

TTO

TTR

USAF

USC

USEC

Toxic Substances Control Act

treatment, storage, and disposal facility

total suspended particulates

total suspended solids

tetrachloroethane

Thermal Treatment Facility

total toxic organics

Tonopah Test Range

U.S. Air Force

United States Code

USGS

U.S. Enrichment Corporation

USNRC

U.S. Geological Survey

UST

VCM

VOC

WAC

WIPP

U.S. Nuclear Regulatory Commission

underground storage tank

voluntary corrective measure

volatile organic compound

WIPPWAC

WMin

waste acceptance criteria

Waste Isolation Pilot Plant

Waste Isolation Pilot Program Waste Acceptance Criteria

waste minimization

WMin/PP

Waste Minimization/Pollution Prevention

WMOA

Waste Minimization Opportunities Assessment 


\section{Approximate Conversion Factors For Selected Si (Metric) Units}

\begin{tabular}{|l|c|l|}
\hline \multicolumn{1}{|c|}{ Multiply SI (Metric) Unit } & By & \multicolumn{1}{c|}{$\begin{array}{c}\text { To Obtain U.S. } \\
\text { Customary Unit }\end{array}$} \\
\hline Cubic Meters $\left(\mathrm{m}^{3}\right)$ & 35 & Cubic feet $\left(\mathrm{ft}^{3}\right)$ \\
\hline Centimeters $(\mathrm{cm})$ & 0.39 & Inches (in.) \\
\hline Meters $(\mathrm{m})$ & 3.3 & Feet $(\mathrm{ft})$ \\
\hline Kilometers $(\mathrm{km})$ & 0.62 & Miles (mi) \\
\hline Square kilometers $\left(\mathrm{km}^{2}\right)$ & 0.39 & Square miles $\left(\mathrm{mi}^{2}\right)$ \\
\hline Hectares (ha) & 2.5 & Acres \\
\hline Liters $(\mathrm{L})$ & 0.26 & Gallons (gal.) \\
\hline Grams $(\mathrm{g})$ & 0.035 & Ounces (oz) \\
\hline Kilograms $(\mathrm{kg})$ & 2.2 & Pounds (lb) \\
\hline Micrograms per gram $(\mu \mathrm{g} / \mathrm{g})$ & 1 & Parts per million $(\mathrm{ppm})$ \\
\hline Milligrams per liter $(\mathrm{mg} / \mathrm{L})$ & 1 & Parts per million $(\mathrm{ppm})$ \\
\hline Celsius $\left({ }^{\circ} \mathrm{C}\right)$ & ${ }^{\circ} \mathrm{C} 9 / 5+32$ & Fahrenheit $\left({ }^{\circ} \mathrm{F}\right)$ \\
\hline
\end{tabular}




\section{EXECUTIVE SUMMARY}

As required by U.S. Department of Energy (DOE) Order 5400.1, this site environmental report has been prepared for Sandia National Laboratories/New Mexico (SNL/NM) to summarize environmental data that characterize site environmental management performance, confirm compliance with federal, state, and local environmental standards and requirements, and highlight major programs and efforts.

SNL/NM is located southeast of Albuquerque, NM, on Kirtland Air Force Base (KAFB). SNL/NM conducts research and development activities in the areas of weapon systems, nuclear reactor safety, energy sources, waste management, and environmental cleanup technologies. Some of these activities have the potential to release hazardous materials to the environment. Historically, these releases have been relatively low compared to other DOE activities.

To ensure that SNL/NM operations will not impose undue risk to the public, various environmental management and monitoring programs have been implemented. Major categories of environmental activities include environmental impact studies, pollution prevention, environmental monitoring, waste management, and environmental restoration. In calendar year 1994 (CY94), two new monitoring programs were established. One is the ambient air monitoring program, which was designed to monitor both radioactive and hazardous materials in the surrounding air. The other program is the meteorological monitoring program, which provides data for characterizing transport and diffusion of air pollutants.

The following paragraphs present major accomplishments of various environmental programs and results of monitoring activities.

Environmental Assessment-In CY94, SNL/NM initiated the preparation of 15 Environmental Assessments for proposed research activities. Findings of no significant impact (FONSIs) were issued for the neutron generator/switch tube prototyping relocation and for the construction of occupancy of the Robotic Manufacturing Science and Engineering Laboratory.

Pollution Prevention-Major activities accomplished in CY94 included the development of a corporate pollution prevention plan, the formation of Pollution Prevention and Reduction teams and an affirmative procurement team, and the organization of the first SNL/NM Earth Day Festival cosponsored by DOE and KAFB.

Waste Management-During 1994, a total of 691,693 kilograms $(\mathrm{kg})$ of waste was managed by SNL/NM's Waste Operations Department. It included 86,369 kg of Resource Conservation and Recovery Act (RCRA) regulated hazardous waste and 605,324 kg of solid and recycled materials. The volume of RCRA hazardous waste processed in 1994 decreased from that reported for 1993; however, the quantity of solid and recycled material increased. The volume was mainly influenced by Environmental Restoration (ER) Project remediation activities and recycling operations. 
SNL/NM has a RCRA-permitted storage facility managed by the Waste Operations Department. On July 22, 1994, DOE/KAO transmitted a notification to the NMED of planned physical modifications at the Hazardous Waste Management Facility (HWMF). The Thermal Treatment Facility (TTF) was issued a treatment permit in November 1994 by NMED. The TTF did not treat any residual explosive waste in 1994. A safety assessment for the Radioactive and Mixed Waste Management Facility (RMWMF) was submitted to DOE for review on March 25, 1994. The RMWMF is scheduled to be operational in 1996.

A 1994 NMED audit of the SNL HWMF and generator locations throughout SNL/NM facilities found 10 alleged violations and resulted in a proposed penalty of $\$ 9,240.00$. Corrective actions began during the audit, and all of the compliance issues have been resolved. DOE conducted two appraisals during 1994. DOE/EPD evaluated the Radioactive Material Management Area (RMMA) program in place at SNL/NM, and DOE/EH-24 (Office of Environmental Audit) evaluated the waste management and environmental protection programs and the ER Project. Both evaluations identified strengths and areas for further improvements.

ER Project-The assessment and remediation of potential release sites identified by the ER Project at SNL/NM are being monitored by the U.S. Environmental Protection Agency (EPA) as provided for by the Hazardous and Solid Waste Amendments of 1984 (HSWA) module of the RCRA Part B operating permit. During 1994, assessment efforts continued at several sites and areas, including the Chemical Waste Landfill (CWL), the Mixed Waste Landfill (MWL), Technical Area II (TA-II), the Liquid Waste Disposal System (LWDS), Kauai Test Facility, and Tijeras Arroyo. Voluntary Corrective Measures have been completed at several ER sites, and several more are planned for 1995.

Terrestrial Surveillance-The objectives of radiological and stable metal surveillance activities are to detect any potential releases and/or migration of contaminated material related to on-site operations to off-site (community) locations and also to determine potential impacts of siterelated activities to the off-site population and the surrounding environment. Radiological and nonradiological surveillance sampling took place at off-site, perimeter, and on-site locations.

Most on-site radiological samples collected in CY94 did not show an elevated concentration compared to community samples. A few sites with elevated uranium and tritium concentrations were associated with known contamination and are within controlled areas. Trends observed at several locations will be further investigated.

Nonradiological soil sampling showed that, except for titanium, the concentration means for most of the metals were not significantly different for on-site and off-site locations. The overall results from the sampling program have been consistent for four sampling periods over the last two years. This consistency suggests that the sampling and analysis are not providing anomalous results and that any significant trends in deposition of metals by SNL/NM activities in the future would be detected. Surface-water sampling does not indicate that metal concentrations increase significantly in river water as the Rio Grande flows through Albuquerque.

Air Monitoring-The meteorological monitoring program and the ambient air surveillance program at SNL/NM began in January 1994. The main objective of the meteorological monitoring program, which includes a nine-tower meteorological monitoring network, is to provide representative data for meteorology at SNL/NM. The objective of the ambient air surveillance program is to establish baseline concentration levels for pollutants of concern, 
show compliance with the National Ambient Air Quality Standards (NAAQS) and local ambient air standards, and evaluated effects of laboratory emissions on the public and the environment. The network includes one criteria pollutant monitoring station (CPMS), seven particulate matter (PM) monitoring stations, and four volatile organic compound (VOC) monitoring locations. The CPMS system showed no exceedances or violations in 1994. PM analysis showed metals characteristic of local soil composition. VOC sampling detected slightly higher concentrations of VOCs at the CPMS location, which is near a busy intersection and the motor pool where vehicle maintenance is performed.

Radioactive effluent air monitoring indicated that small quantities of tritium, nitrogen-13, oxygen-15, and argon-41 emissions were released to the atmosphere as a result of SNL/NM operations in 1994. The National Emission Standards for Hazardous Air Pollutants (NESHAP) maximum exposed individual was determined to be located at the U.S. Air Force (USAF) Kirtland Underground Munitions Storage Complex facility. The effective dose equivalent calculated for this location is 0.00053 millirem per year (mrem/yr) or 0.0053 percent of the 10 mrem/yr dose limit specified in NESHAP and in DOE orders. The total population dose for the 50-mile radius surrounding SNL/NM was calculated to be 0.012 person-rem from SNL/NM operations, whereas the population received more than 57,000 person-rem from natural background.

Water Monitoring-In June 1994, SNL/NM activated the TA-V Liquid Effluent Control System (LECS) to retain process waste water for radiological screening prior to disposal into the sanitary sewer. Results of sampling of this system indicate the waste-water discharges from the LECS are below regulatory limits.

SNL/NM has six waste-water discharge permits from the City of Albuquerque. In 1994, five violations of two City permits were determined by 24-hour composite sampling. Oil and grease concentrations exceeded the Permit 2069A-2 limit by 65 milligrams per liter (mg/L). Permit 2069H-2 limits were exceeded for oil and grease by $35 \mathrm{mg} / \mathrm{L}$, nickel by $25.3 \mathrm{mg} / \mathrm{L}$, and lead by $0.48 \mathrm{mg} / \mathrm{L}$ and $0.76 \mathrm{mg} / \mathrm{L}$. The two oil and grease violations were addressed by resampling, which showed that concentrations were within permit limits. To address the nickel violation, test kits were ordered for testing of nickel and copper at the center test point between the lead and lag columns to prevent future excursions. Though evaluated lead levels had never been detected in any previous sampling events, it was conservatively assumed that a sink which bypassed the copper recovery system contributed to the two lead violations, and the sink was removed. Response from EPA has not yet been received on the NPDES individual permit application by SNL/NM industrial discharges; however, the storm-water pollution prevention plan is scheduled for implementation by December 1996. SNL/NM has also submitted two Notices of Intent to Discharge (NOIs) for construction storm-water discharges. There were no violations in surface-water discharges in CY94.

Groundwater Monitoring-Groundwater monitoring activities reported are those associated with the SNL/NM ER Project and the Groundwater Protection Program. The Groundwater Surveillance Task, also referred to as "basewide groundwater monitoring," is the monitoring activity associated with the Groundwater Protection Program. Basewide groundwater monitoring samples were collected during three sampling events in 1994. Water level 
elevations in monitoring wells in the SNL/NM area were measured monthly to infer groundwater flow patterns in the region. Water level data are used to define long-term trends in groundwater quantity at KAFB.

CWL groundwater monitoring was performed at nine wells surrounding the landfill, including two background wells. Four of the nine wells were added in August 1994. Water levels at the CWL have decreased at an average rate of 0.85 foot per year (ft/yr). All VOCs detected were below MCLs. Two metals were found to exceed maximum allowable concentration (MAC) limits.

MWL groundwater monitoring was performed at five monitoring wells in the vicinity of the landfill, including one background monitoring well and one monitoring well located inside the landfill. Generally, water levels at the MWL are declining at an average rate of $0.85 \mathrm{ft} / \mathrm{yr}$. No contaminants above regulatory limits were detected.

LWDS groundwater monitoring was performed at two monitoring wells, one adjacent to the LWDS lagoons, and the other adjacent to the location of the buried LWDS waste line immediately outside TA-IV. Trichloroethylene was detected in the LWDS drainfield monitoring well; a likely source for this contamination lies inside TA-V, approximately 250 feet south of the drainfield. 


\subsection{INTRODUCTION}

As required in U.S. Department of Energy (DOE) Order 5400.1, this site environmental report has been prepared for Sandia National Laboratories/New Mexico (SNL/NM) to summarize environmental data that characterize site environmental management performance, confirm compliance with federal, state, and local environmental standards and requirements, and highlight significant programs and efforts (DOE 1988a). This report represents a key component of the DOE's effort to keep the public informed about environmental conditions at SNL/NM. The report contains summary information about the radiological and nonradiological conditions of the site environment and identifies trends with regard to effluent releases and environmental conditions.

\subsection{SITE OPERATION}

SNL/NM is managed and operated by Sandia Corporation, a prime contractor of the DOE. Sandia Corporation is a wholly owned subsidiary of Lockheed Martin Corporation. SNL/NM's mission includes national security, energy, environmental science and technology, and the fields of fundamental science, which underpin these missions.

Projects include the weaponization of nuclear explosives and the designing of arming, fusing, and firing systems used in nuclear bombs and warheads, nuclear reactor safety studies for the U.S. Nuclear Regulatory Commission (USNRC), development of safe transport and storage systems for special nuclear materials including plutonium $(\mathrm{Pu})$ and uranium $(\mathrm{U})$, radioactive waste disposal techniques and site studies, pulsed power research, thermonuclear fusion research, solar energy research, environmental technologies research, and fossil fuel and geothermal energy research. Safety, reliability, and survivability of weapon systems receive primary emphasis.

\subsection{LOCATION AND POPULATION}

SNL/NM is located in Bernalillo County at the foot of the Manzano Mountains adjacent to Albuquerque, NM (Figure 1-1). At their nearest points, SNL/NM facilities are 2.5 miles (mi) south of Interstate 40 and approximately $6.5 \mathrm{mi}$ east of downtown Albuquerque. The facilities are surrounded by Kirtland Air Force Base (KAFB) East, with co-use agreements on some U.S. Air Force (USAF) property. An area of the Manzano Mountains east of KAFB has been withdrawn from the U.S. Forest Service for the exclusive use of the Air Force and the DOE.

The laboratory consists of five technical areas and several remote test areas situated in the eastern half of the 118-square-mile $\left(\mathrm{mi}^{2}\right) \mathrm{KAFB}$ military reservation. KAFB is located on two broad mesas bisected by the Tijeras Arroyo, an east-west canyon. These mesas are bound by the Manzano Mountains (Cibola National Forest) to the east and the Rio Grande to the west. Elevations in the area range from 4,921 feet (ft) at the Rio Grande to $10,678 \mathrm{ft}$ at Sandia Crest, which is in the Sandia Mountains adjacent to Albuquerque. KAFB is at a mean elevation of $5384 \mathrm{ft}$. 


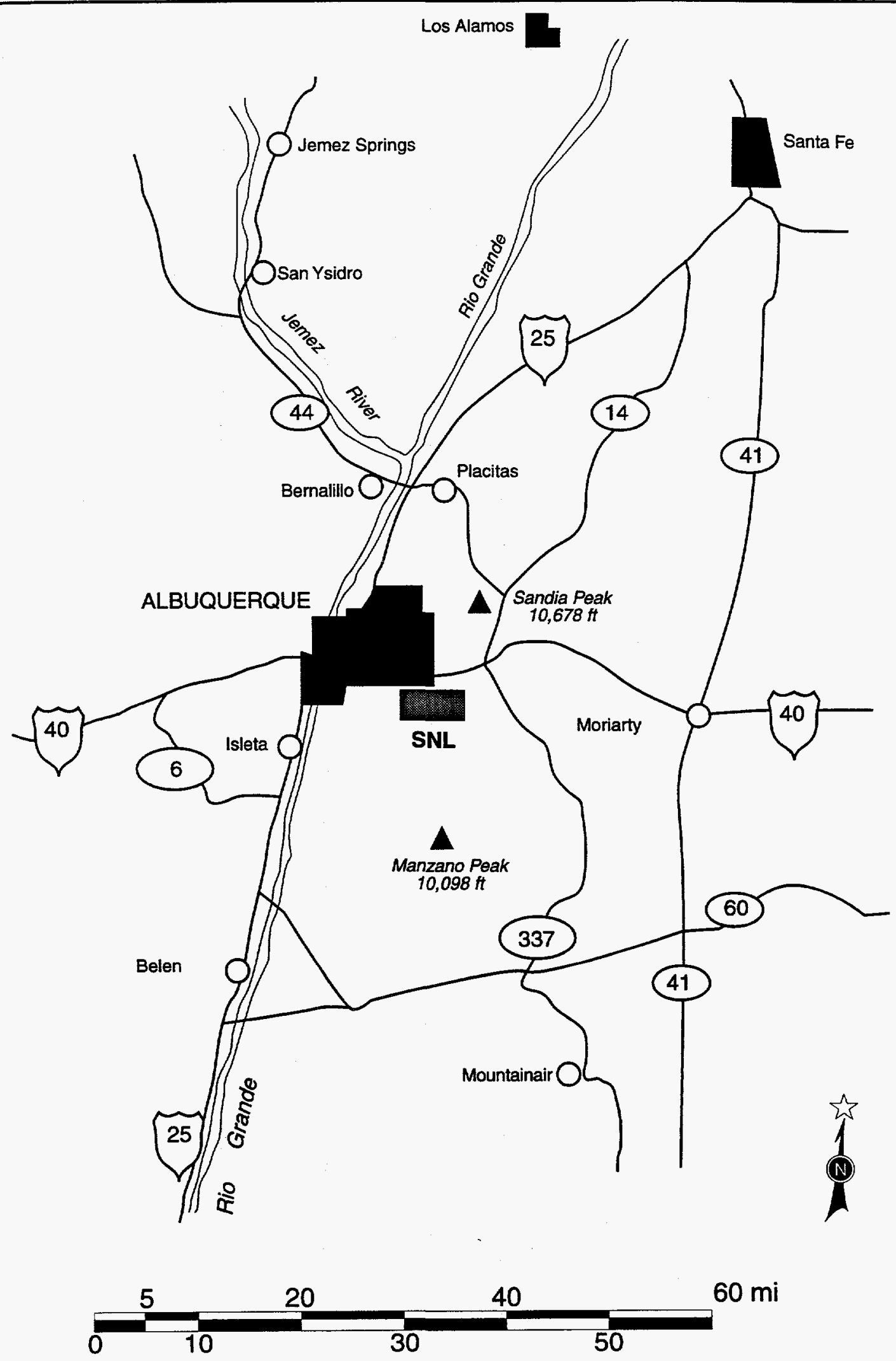

Figure 1-1. Albuquerque Site Regional Setting 
The largest population center in Bernalillo County, and also the closest population center to KAFB, is Albuquerque, located slightly north of the base. The 1990 census figures show an Albuquerque population of 384,736 . The Isleta Indian Pueblo, which borders KAFB on the south, is the next nearest population center with a 1990 census of 2953 . An estimated total population of 578,313 people live within a 50-mi radius of KAFB (DOC 1992). This includes permanent residents of KAFB living in the KAFB housing areas.

\subsection{CLIMATE AND METEOROLOGY}

The Albuquerque-Belen Basin is characterized by low precipitation, wide temperature extremes, frequent, drying winds, heavy rain showers, usually short in duration and often with erosive effects, and erratic, seasonal distribution of precipitation. Albuquerque air temperatures are characteristic of high-altitude, dry continental climates. Daytime temperatures during the winter average approximately 50 degrees Fahrenheit $\left({ }^{\circ} \mathrm{F}\right)$, and summer daytime temperatures generally are less than or equal to $90^{\circ} \mathrm{F}$, except in July, when the maximum reaches $93^{\circ} \mathrm{F}$ (see Appendix A, Table A-1). The average annual precipitation is 8.2 inches (in.); half of this precipitation occurs from July through September in the form of brief thundershowers. Winter months are typically dry with less than 2.0 in. of precipitation normally recorded. The average annual relative humidity is approximately 43 percent (see Appendix A, Table A-1). Strong winds, often accompanied by blowing dust, occur mostly in late winter and early spring.

SNL/NM land stretches to the eastern edge of the basin, toward the Sandia and Manzano mountains. Two topographic features, mountains and canyons, influence local wind patterns across the laboratories. The atmospheric state variables of temperature, relative humidity, and rainfall do not vary dramatically across a climatic regime; topographically induced wind flows vary within the same climatic regime. Canyons tend to channel or funnel wind, whereas mountains create upslope-downslope diurnal wind flows. These topographically induced wind flows can be enhanced or negated by synoptic weather systems that move across the regime.

Appendix A includes annual climatic and wind information for meteorological towers located across SNL/NM. Section 5.1 contains a description of SNL/NM's meteorological monitoring program.

\subsection{GEOLOGY}

The Albuquerque Basin trends north-south within the Rio Grande Rift Zone (Figure 1-2). The uplifted fault blocks of the Sandia and Manzano mountains comprise the eastern basin boundary. The west side of the basin is bounded by the Nacimiento Uplift, the Lucero Uplift, and the Ladron Mountains. During the Miocene and Pliocene, the basin filled with as much as $12,000 \mathrm{ft}$ of sediments eroded from the surrounding highlands. This sediment sequence, the Santa Fe Group, thins toward the edge of the basin where it is truncated at the bounding uplifts. Santa Fe Group sediments are overlain in places by Pliocene Ortiz gravel and Rio Grande fluvial deposits and are interbedded with Tertiary and Quaternary basalts and pyroclastics. Basin-fill alluvial fans of the Santa Fe Group consist of channel, debris flow, 


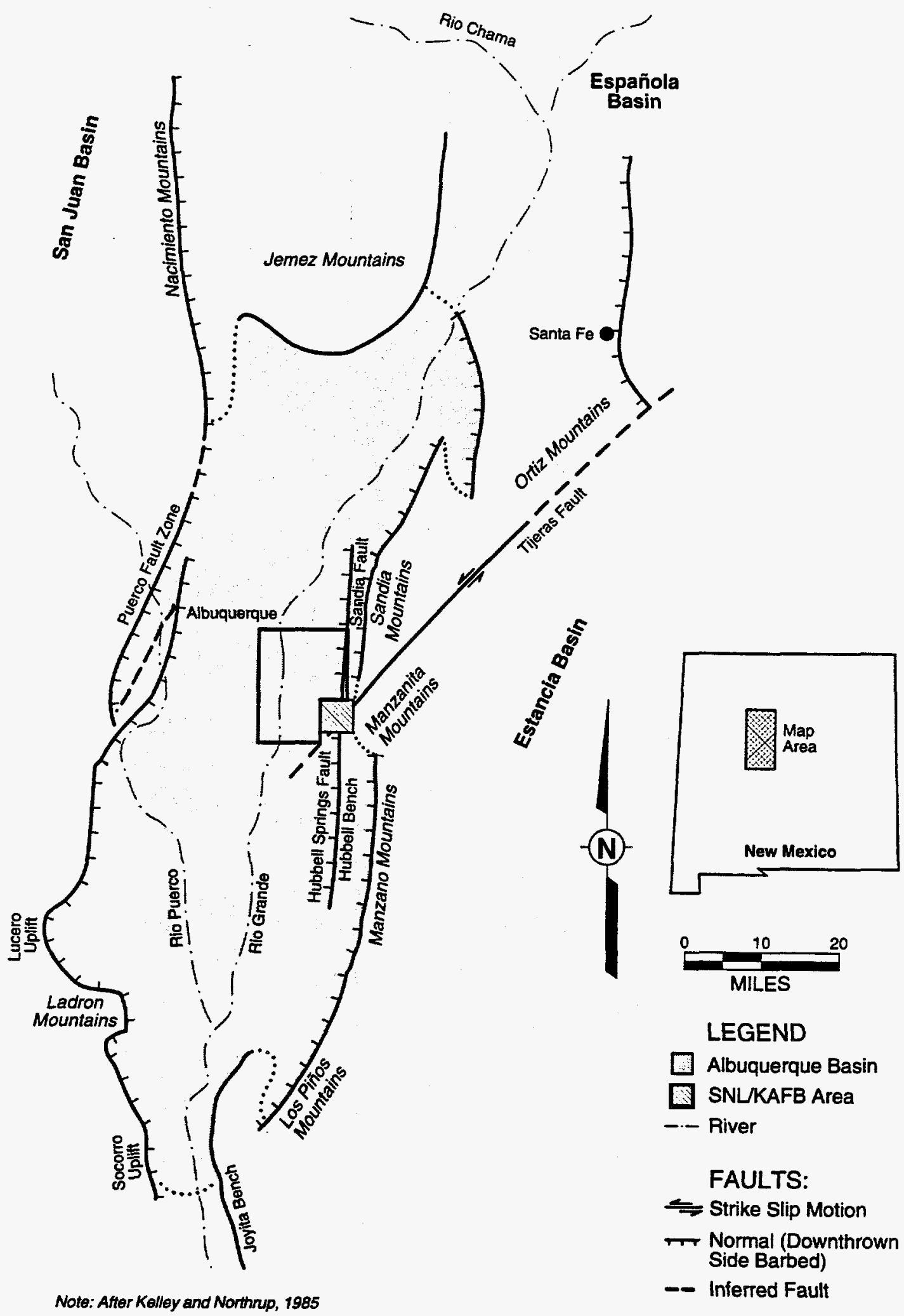

Figure 1-2. Albuquerque Basin of North Central New Mexico (Kelley and Northrup 1975) 
floodplain, and interlayered eolian deposits. Grain sizes range from clay to boulders with moderately well-developed stratification and some graded bedding. Bed thickness varies from inches to feet and most of the bedding is probably lenticular with limited areal extent, although buried channels can extend downdip (westward) for long distances.

The geology underiying the eastern section of KAFB includes major faulting (Figure 1-3). The younger (Tertiary age) Hubbell Springs and Sandia faults are north/south-trending, down-tothe-west, en echelon faults (Lozinsky et al. 1991; Woodward 1982; Kelley and Northrop 1975). The Hubbell Springs fault extends northward from Socorro County, NM, to the southern portion of KAFB. The Sandia fault is probably the primary boundary between the Sandia Mountains uplift and the main Albuquerque basin, and may actually be an extension of the Hubbell Springs fault (Kelly 1977). The Tijeras fault is a scissors-type fault of Precambrian origin with left-lateral offset that appears to be downthrown to the southeast near the Four Hills area of KAFB as a result of Cenozoic movement (Kelley and Northrop 1975) and is assumed to be the boundary between the Sandia and Manzano uplifts. The Tijeras, Sandia, and Hubbell Springs faults probably converge near the Chemical Waste Landfill (CWL) at SNL/NM Technical Area III (TA-III).

\subsection{HYDROLOGY}

The fault complex separates the regional aquifer system into a deeper zone west of the faults and a relatively shallower zone east of the faults. The depth to groundwater underlying SNL/NM facilities varies from approximately 50 to $100 \mathrm{ft}$ east of the faults and from approximately 380 to $500 \mathrm{ft}$ west of the faults. The hydrogeology east of the faults is poorly understood because there are few wells and the geology between the faults and the canyons of the Manzanita Mountains is complex. Most of the water supply and the majority of the monitoring wells east of the faults are located in fractured bedrock with modest yields. Groundwater typically flows out of the canyons and westward toward the fault complex. Titus (1963), in describing flow across the Ojuelos fault in Valencia County, concludes, "As water moves across the fault into the more permeable rocks of the Santa Fe, it cascades abruptly to the lower level within a short distance." On KAFB, a change in the water surface elevation of over $700 \mathrm{ft}$ in a 2-mi distance (from Explosive Ordnance Disposal [EOD] Hill west to the $\mathrm{CWL}$ ) resulted in a hydraulic gradient of approximately 0.07 . West of the faults, the hydraulic gradient decreases to approximately 0.005 , and the depth to bedrock increases rapidly. The apparent direction of groundwater flow is generally westward (toward the Rio Grande) but trends more northward near the KAFB pumping wells. Although the impact of the KAFB wells (and nearby City of Albuquerque wells) is shown by the fluctuations in monitoring-well water levels at the KAFB Sanitary Lagoons, the radial extent of the cone of depression is undetermined at this time.

The major surface-hydrologic feature in central New Mexico is the Rio Grande, which flows north to south through Albuquerque and lies approximately $6 \mathrm{mi}$ west of KAFB. Rio Grande water is primarily used for irrigation of agricultural crops. There are no continuously running streams on SNL/NM property, although there are two perennial springs (Coyote and Sol se Mete) on KAFB and one (Hubbell Springs) on Isleta Pueblo, south of KAFB. The two 


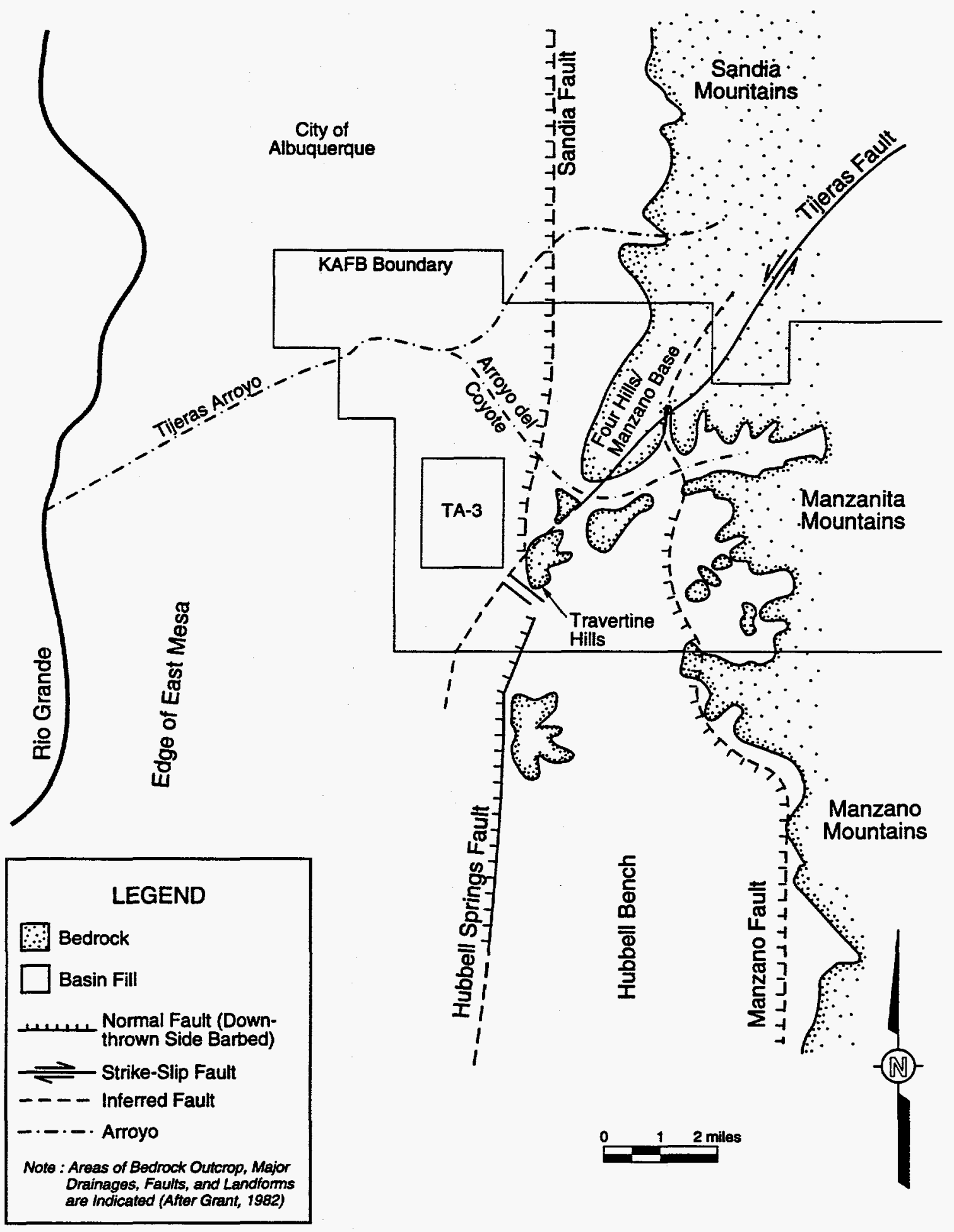

Figure 1-3. Generalized Geology in the Vicinity of SNL/NM and KAFB. Areas of bedrock outcrop, major drainages, faults, and landforms are indicated (Grant 1982). 
primary surface channels at SNL/NM are Tijeras Arroyo and the smaller Arroyo del Coyote (Figure 1-3). Arroyo del Coyote joins Tijeras Arroyo approximately $1 \mathrm{mi}$ west of the Tijeras Arroyo Golf Course; both flow intermittently during heavy summer thundershowers. Tijeras Arroyo (above the confluence with Arroyo del Coyote) drains approximately $80 \mathrm{mi}^{2}$; Arroyo del Coyote (above the confluence with Tijeras Arroyo) drains approximately $27 \mathrm{mi}^{2}$ (U.S. Army Corps of Engineers 1979). Neither drainage is a significant flood hazard, and any impact on groundwater resources from flooding would likely be minimal. All active SNL/NM facilities are located outside the 500-yr floodplain described by the U.S. Army Corps of Engineers (1979) for both arroyos. The extent of infiltration (and potential groundwater recharge) in the primary surface channels is currently unknown.

\subsection{BIOLOGY}

The semidesert Southwest climate produces low surface-water availability, resulting in many species of drought-resistant flora such as grasses and cacti (ERDA 1977). Figure 1-4 shows the mesa vegetation on KAFB, consisting of grasses and shrubs. Figure 1-5 shows juniper trees and cacti at the higher elevations bordering the mountains east of KAFB. Russian thistle (tumbleweeds) proliferate in mechanically disturbed areas. The City of Albuquerque, adjacent to KAFB, has flora typically found in urban environments. The wildlife communities at KAFB are typical of the equivalent woodland and grassland habitat types in central New Mexico (IT and Consensus Planning 1993).

\subsection{TECHNICAL AREAS}

SNL/NM consists of five technical areas and several additional test areas (Figure 1-6). Each area has its own distinctive operations. The following paragraphs describe the activities in each area and summarize potential sources for radioactive and nonradioactive effluent releases.

TA-I operations are dedicated primarily to three activities: the design, research, and development of weapons systems; limited production of weapon system components; and energy programs. TA-I facilities include the main library and offices, laboratories, and shops used by administrative and technical staff. Potential sources for nonradioactive effluents include the paint shops, process development laboratory, emergency diesel generator plant, solvent spray booth, foundry, and steam plant. Small quantities of radioactive materials are used and stored in several facilities within TA-I.

TA-II is used to test explosive components and to develop techniques for measuring fractures in geologic strata. Microcurie $(\mu \mathrm{Ci})$ amounts of tritium may be released each year from testing. Also located in TA-II are a low-level radioactive waste (LLW) disposal site that has been inactive over 20 years, a small radioactive material decontamination and storage facility (Building 906), and a storage facility designed to temporarily hold polychlorinated-biphenylcontaminated materials to be transported to an EPA-licensed disposal facility. The Explosive Components Facility (ECF) will integrate many TA-II activities and some remote testing activities currently performed in other test areas. 


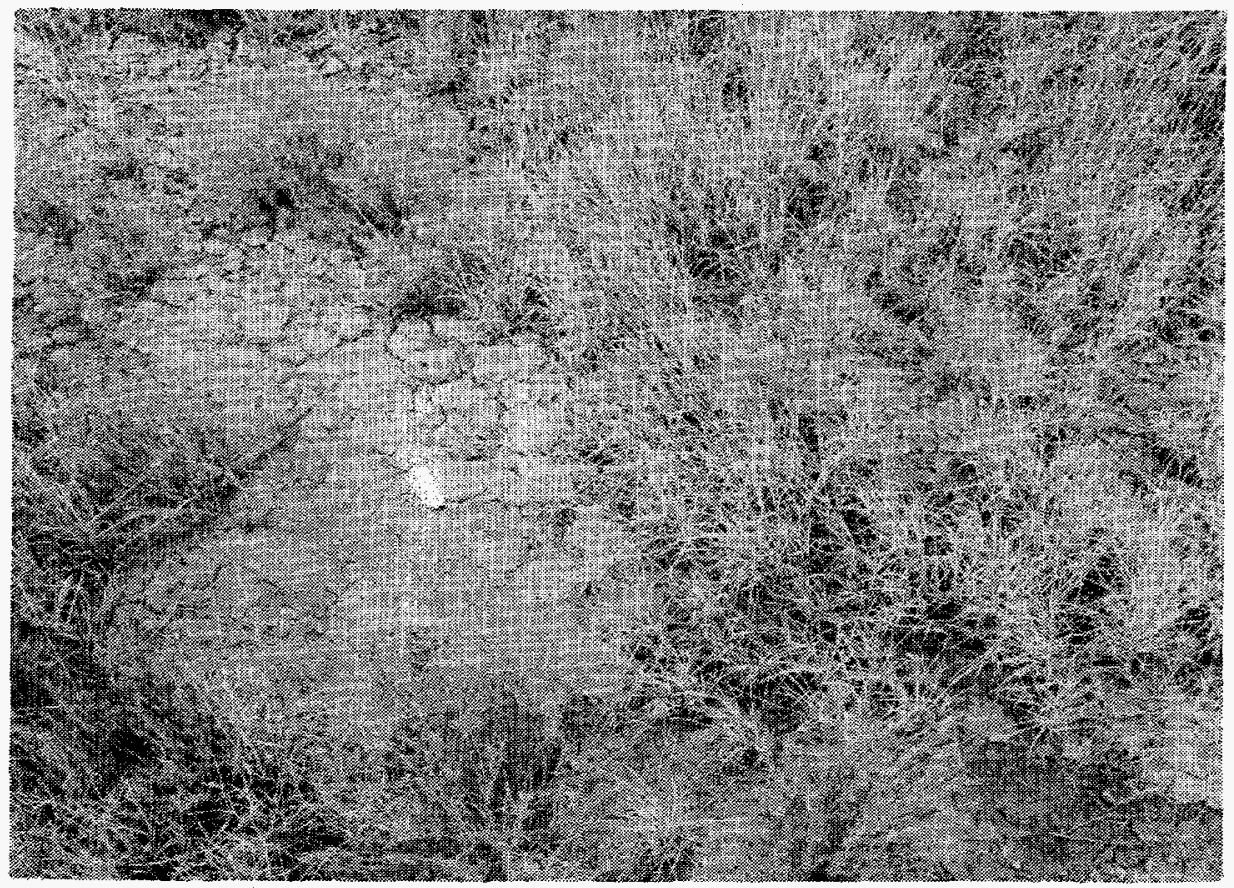

Figure 1-4. Mesa Vegetation

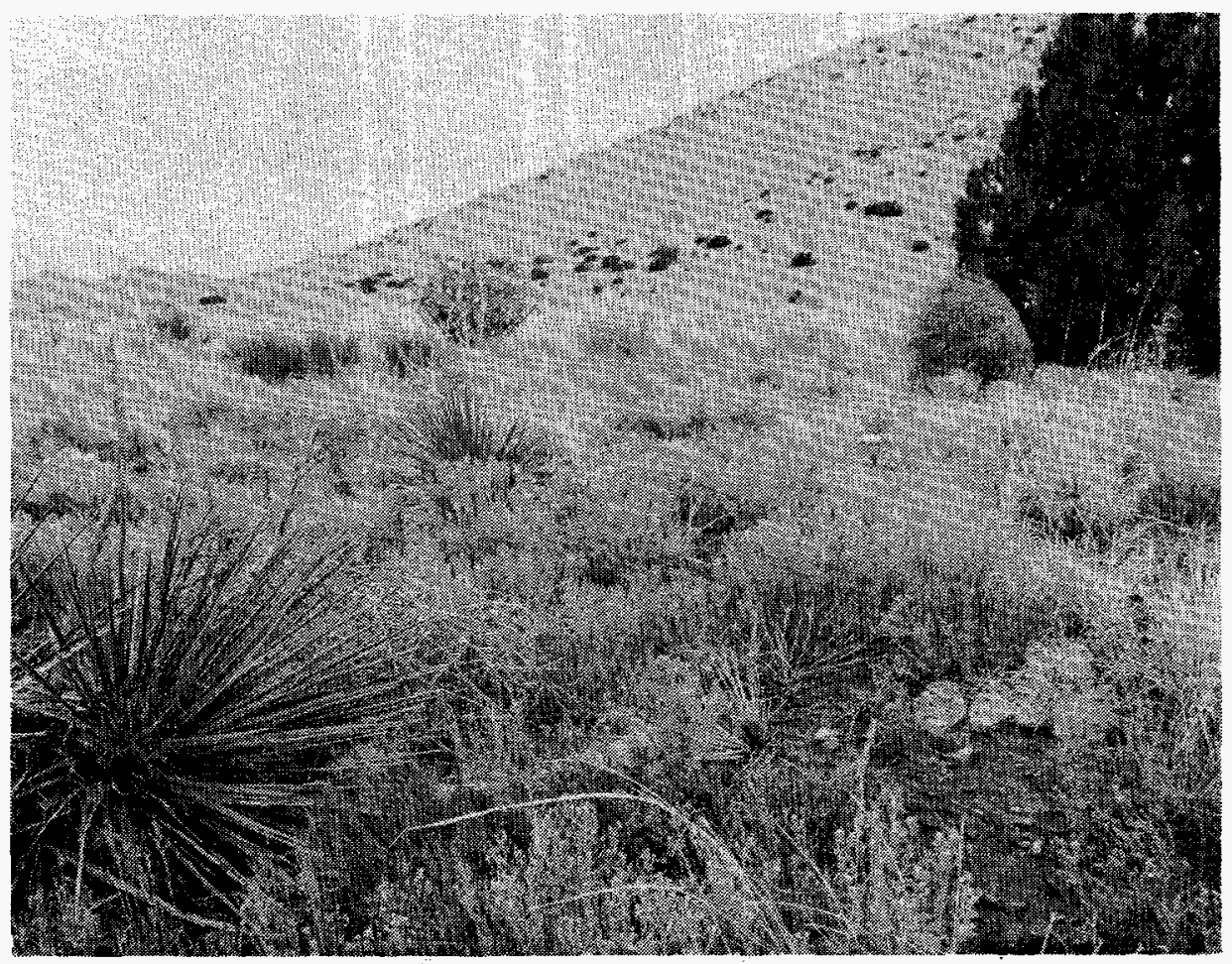

Figure 1-5. Manzano Foothills Vegetation 


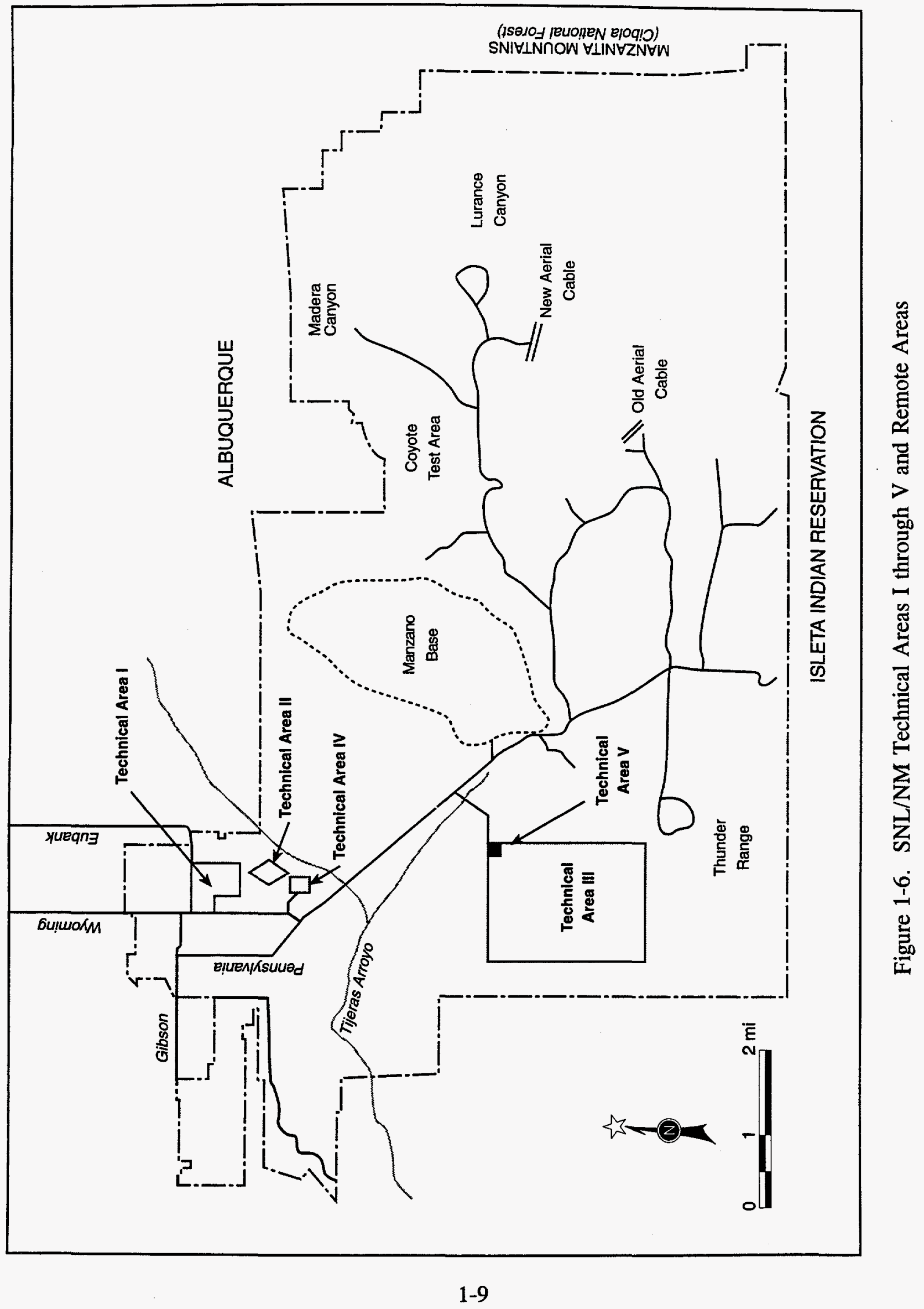


TA-III is adjacent to and south of TA-V, $5 \mathrm{mi}$ south of TA-I. TA-III facilities include extensive environmental test facilities (such as sled tracks, centrifuges, and a radiant heat facility). No radioactive effluents are released through normal operations in the area with the exception of small quantities of depleted uranium (DU) associated with sled track testing. Other facilities in TA-III include a paper incinerator, inactive chemical waste, mixed waste, and LLW landfills, the Large-Scale Melt Facility (LMF), the Melting and Solidification Laboratory (MSL), and the Solar Tower Facility. The inactive CWL; closed in 1985, was used for storage of chemical waste from 1985 to 1988 (SNL 1992a). The mixed waste landfill (MWL) in TA-III was closed in 1988 and consists of two adjoining fenced areas that occupy 0.6 hectares (SNL 1989). One area used for LLW disposal consists of seven shallow trenches. The second area was used for disposal of classified LLW in 37 pits. LLW consisted primarily of tritium-contaminated materials. Three additional pits located in the classified waste disposal area were used exclusively for natural and DU waste disposal. The Radioactive and Mixed Waste Management Facility (RMWMF) serves as a central processing facility for packaging and storage of low-level and mixed waste. Sources in TA-III arise from disposal operations involving low-level, mixed, classified, and unclassified radioactive wastes.

TA-IV consists of several inertial-confinement fusion research and pulsed-power research facilities. One large accelerator, the Particle Beam Fusion Accelerator-II (PBFA-II), was completed in 1985. A large accelerator facility, the Simulation Technology Laboratory (STL), houses seven pulsed-power accelerators: High Energy Radiation Megavolt Electron Source-III (HERMES-III), Recircling Linear Accelerator (RLA), Troll, Simulated Test Facility (STF), Speed, Hydramite, and Proto II. Several of these accelerators were transferred from TA-V. Another accelerator facility, Saturn, and a major research facility, the Strategic Defense Facility (SDF), are also part of TA-IV facilities. Gaseous tritium effluents, primarily tritiated water, are released from fusion research efforts. Radioactive emissions from the SDF are short-lived radionuclides, primarily nitrogen-13 and oxygen- 15 .

TA-V contains two research reactors facilities, an intense gamma irradiation facility (using cobalt-60 and cesium-137), and a hot cell facility.

The two research reactor facilities in TA-V are small and quite dissimilar: the Sandia Pulsed Reactor-III (SPR-III) is an unreflected, unmoderated assembly of enriched uranium; the Annular Core Research Reactor (ACRR) consists of an annular core of 226 fuel elements in an open water tank. Both the SPR and ACRR air exhaust systems are equipped with particulate effluent samplers. The ACRR also has a continuous gaseous effluent monitor. The airborne releases are air activation products from reactor operations primarily composed of argon-41.

\subsection{REMOTE TEST AREAS}

SNL/NM also has test areas outside the five technical areas. These test areas are located south of TA-III and in canyons on the west side of the Manzano Mountains. Coyote Canyon and Thunder Range are two examples of such areas. In these remote test areas, wild animals, including snakes, deer, coyotes, and owls, are often present. 
DU was infrequently spread over limited areas during explosive testing in some of these remote test areas. The test areas were surveyed following each test, and contaminated materials were collected and disposed of in accordance with DOE requirements. Environmental monitoring is done as necessary. Operations in these areas are administratively controlled to avoid exposure to uranium. 


\subsection{COMPLIANCE SUMMARY}

\subsection{COMPLIANCE REGULATIONS}

Sandia National Laboratories (SNL) strives to comply with environmental and other requirements established by federal and state statutes and regulations, executive orders, and U.S. Department of Energy (DOE) orders. The following paragraphs summarize the status of Sandia National Laboratories/New Mexico (SNL/NM) in complying with major environmental statutes.

\subsubsection{Comprehensive Environmental Response, Compensation and Liability Act (CERCLA)}

CERCLA and the Superfund Amendments and Reauthorization Act (SARA) define certain assessment activities and reporting requirements for inactive waste sites for all federal facilities. As required, CERCLA Section 103(c) (DOE 1989a) notifications were provided to the U.S. Environmental Protection Agency (EPA). Based on the Preliminary Assessment/Site Inspection (PA/SI) performed in 1988 as required by SARA 120(c), the EPA has determined that none of the SNL/NM inactive waste sites qualifies for the EPA list of high-priority cleanups (i.e., none of the sites are on EPA's National Priorities List [NPL]). With respect to the SNL/NM inactive waste sites on Kirtland Air Force Base (KAFB), no other CERCLA or SARA activities are required. On October 1, 1992, SNL/NM submitted a National Pollutant Discharge Elimination System (NPDES) permit application for its storm-water discharges.

There were two reportable quantity (RQ) chemical releases in 1994. Transformer oil leaked from an oil storage system and escaped from the system's secondary containment. The second $\mathrm{RQ}$ was lead released during a scheduled rocket motor firing. Although it was not "accidental," this release was reportable under CERCLA.

\subsubsection{Resource Conservation and Recovery Act (RCRA)}

The RCRA requires a comprehensive program for managing hazardous wastes from generation of those wastes to their ultimate disposal. RCRA goals are to reduce the volume and toxicity of wastes and to minimize the amount of waste requiring land disposal. RCRA addresses the generation, storage, treatment, recycling, transport, and disposal of hazardous, mixed, and nonhazardous solid waste in several ways. Chemical hazardous waste and underground storage tanks (USTs) for hazardous substances are regulated by RCRA. RCRA also requires documented waste minimization programs. Land disposal restrictions (LDRs) and treatment standards for chemical waste are required by RCRA. Radioactive mixed waste is dually regulated by RCRA and the Atomic Energy Act.

RCRA, Environmental Restoration (ER) Project - The potential release sites identified by the ER Project for facilities at SNL/NM are being evaluated and corrected as required by RCRA 3004(u). Corrective actions (CAs) for releases from Solid Waste Management Units (SWMUs) are a part of the Hazardous and Solid Waste Amendments (HSWA) module, RCRA Part B permit, issued August 26, 1993. 
SNL/NM has an inactive Chemical Waste Landfill (CWL) that was issued an interim status in 1985. A closure plan was developed for this site following the requirements described in RCRA, Title 40, Code of Federal Regulations, Part 265 (40 CFR 265). Due to the discovery of trichloroethylene (TCE) at concentrations slightly above the EPA's drinking water standard in groundwater 500 feet beneath the site, a corrective action plan for remediation of the TCE, a volatile organic compound (VOC), was incorporated into the closure plan, entitled The Chemical Waste Landfill Final Closure Plan and Postclosure Permit Application (SNL 1992a). This plan was approved by the New Mexico Environment Department (NMED) in May 1993.

In January 1990, the State of New Mexico adopted the federal UST regulations (40 CFR 280). The state regulations use the age of the USTs rather than depth to groundwater as the basis for determining removal or replacement actions. At present, 40 tanks have been removed, and 24 USTs remain to be addressed.

RCRA, Hazardous Waste Management - SNL/NM is a large-quantity generator and has a permitted storage facility managed by the Waste Operations Department. On May 12, 1994, DOE/KAO transmitted a Class 1 permit modification of the RCRA storage permit for the Hazardous Waste Management Facility (HWMF) primarily to NMED. The modification was for receipt of off-site SNL-generated waste.

The Thermal Treatment Facility (TTF) was issued a treatment permit in November 1994 by NMED. The permit allows thermal treatment of residual explosives generated at SNL/NM and primarily addresses treatment of D003 waste contaminated with D001, D011, F003, and F005.

NMED performs annual RCRA audits of the SNL HWMF and generator locations throughout SNL/NM facilities. The NMED 1994 audit included NMED enforcement bureau personnel. NMED personnel spent five days auditing $\mathbf{5 0 0}$ generators' sites in all five technical areas. A Compliance Order was issued on October 7, 1994, listing 17 alleged violations. The types of violations included open containers of hazardous waste, labeling errors, incomplete training, incomplete inspection data, and incomplete LDR forms. Negotiations between NMED and SNL in December 1994 resulted in the suspension of five of the initial violations. A civil penalty of $\$ 9,240.00$ was proposed in January 1995 . Corrective actions began immediately during the audit, and all of the compliance issues have been resolved.

RCRA. Mixed Waste Management - The State of New Mexico was granted regulatory authority for MW under RCRA on July 25, 1990. In August 1990, SNL/NM submitted a RCRA Part A permit application for MW to the NMED.

In October 1992, SNL/NM devised a permitting strategy that called for a phased submittal of the Part B permit application (i.e., a Part B permit application and two major amendments at specified intervals) for storage and treatment units. The strategy was submitted to NMED in the form of a Letter Agreement. The Part B permit application (the first portion of the phased submittal) was submitted to NMED on schedule November 8, 1992. The first amendment was submitted to NMED on schedule August 26, 1993. The second amendment was submitted to 
NMED on January 31,1995 . If further waste treatment units are required to meet RCRA LDRs, a third amendment will be considered for submittal to permit these treatment units.

In addition, the SNL/NM Part A permit application was revised to correct errors in the August 1990 Part A permit application, consolidate some storage units, add eight treatment processes, and assure comprehensive coverage of all $\mathrm{MW}$ expected to be managed at SNL/NM. Plans call for permitting nine MW storage units and, initially, four treatment processes. The remaining units included on the Part A permit application will be closed under interim status or administratively withdrawn.

On December 30, 1992, the EPA, Region VI, issued a "Notification of Noncompliance and Necessity for Conference in Regard to the Land Disposal Restrictions for the United States Department of Energy, Sandia National Laboratories." The Notification of Noncompliance (NON) began the process toward full compliance with the LDRs at SNL/NM through a Federal Facilities Compliance Agreement. The DOE and SNL/NM took all the necessary steps to comply with the NON, beginning with a conference with EPA and NMED on April 26, 1993.

In October 1992, the Federal Facility Compliance Act (FFCA) was enacted, amending RCRA. SNL/NM began compiling the MW inventory that was required within 180 days of enactment.

The process of negotiating a Federal Facilities Compliance Agreement was cancelled by EPA on June 11,1993 , and replaced by a process developed by DOE for implementation of the October 1992 FFCA. As part of the requirements of the FFC Act, SNL/NM submitted its MW inventory for the preliminary report required within 180 days of enactment and updated this inventory in November 1993 for the Final Mixed Waste Inventory Report (DOE 1993a). Also, as part of compliance with the FFCA, the Conceptual Site Treatment Plan (Phase I) for SNL/NM MW (SNL 1993a) was submitted to NMED in October 1993 and the subsequent Draft Site Treatment Plan (DSTP) (Phase II) in August 1994.

The DSTP addressed treatment plans for MW covered by the final phase of the Mixed Waste Inventory Report (i.e., through December 1992). Additional inventory through September 1994 is addressed in the Proposed Site Treatment Plan (PSTP) (Phase III) which was drafted and submitted for DOE Headquarters review in December 1994. The PSTP identifies preferred treatment options in accordance with the DOE/AL Mixed Waste Treatment Plan (April 1994) and the DOE Options Analysis Team recommendations. The SNL/NM plan is heavily based on the use of Mobile Treatment Units being designed and built at other DOE/AL sites. The PSTP was submitted by DOE to NMED in March 1995 . It will be the basis of a Compliance Order to be issued before October 6, 1995.

\subsubsection{National Environmental Policy Act (NEPA)}

Several DOE policy directives and other NEPA initiatives issued over the last several years have increased the emphasis on NEPA compliance at SNL/NM. These directives and initiatives include: 
- The Secretary of Energy's NEPA Notice (SEN-15-90) of February 5, 1990.

- DOE's 1992 NEPA rule (10 CFR 1021).

- The revised DOE NEPA Order 5440.1E (DOE 1992a).

- The June 1994 Secretary's Policy Statement on the National Environmental Policy Act (DOE 1994a).

DOE's commitment to infusing environmental values into DOE decision making and disclosing federal activities through the NEPA process has resulted in an increase in the number of NEPA documents being written to address SNL/NM's proposed actions. During 1994, SNL/NM NEPA compliance activities focused on several items.

- Fulfilling commitments made in the Final Action Plan to Tiger Team (SNL 1992b).

- Developing baseline information.

- Developing the NEPA program.

In 1994, NEPA compliance activities increased. Policies and procedures were further developed to ensure environmental values are considered as part of the review of SNL/NM proposed actions.

Findings of no significant impact (FONSIs) were issued after the satisfactory completion of three environmental assessments.

- Neutron Generator/Switch Tube (NG) Prototyping Relocation (DOE/EA-0885); FONSI issued April 8, 1994 (DOE 1994b).

- Construction and Occupancy of the Robotic Manufacturing Science and Engineering Laboratory (RMSEL) (DOE/EA-0879); FONSI issued April 13, 1994 (DOE 1994c).

- General-Purpose Heat Source Safety Verification Testing (DOE/EA-1025); FONSI issued February 15, 1995 (DOE 1995).

The NEPA program was responsible for the publication of six technical reports in 1994: two papers were written on the NEPA program and four reports contained baseline information.

Section 3.5 contains more detailed information about the NEPA program.

\subsubsection{Clean Air Act (CAA)}

For air quality compliance, SNL/NM is regulated by the 1990 Clean Air Act Amendments (CAAA), ambient air quality standards, and local regulations such as Air Quality Control Regulations (AQCR) for Albuquerque and Bernalillo County. SNL/NM also periodically applies for open-burn permits (AQCR \#3), as well as soil disturbance permits (AQCR \#8), for 
the control of airborne particulates. Other regulations such as AQCR \#5 for visible air contaminants, AQCR \#11 for volatile organic compounds, and AQCR \#15 through \#18 for emission standards of nitrogen dioxide $\left(\mathrm{NO}_{2}\right)$, sulfur dioxide $\left(\mathrm{SO}_{2}\right)$, and particulate matter (PM) from oil- and gas-burning equipment also apply to SNL/NM on a source-specific basis.

Titles III, V, and VI of the CAAA contain other compliance mandates. Title V of the CAAA requires existing major sources/facilities to obtain operating permits as promulgated in $40 \mathrm{CFR}$ 70 and AQCR \#41. Title VI protects the stratospheric ozone by limiting the use of Class I and Class II ozone-depleting substances (ODSs) as promulgated in 40 CFR 82 and AQCR \#37. SNL/NM also complies with AQCR \#31 and the 40 CFR 61 National Emission Standards for Hazardous Air Pollutants (NESHAP) for radionuclide air emissions (Subpart H), beryllium (Be) air emissions (Subpart C), and asbestos emissions (Subpart M).

An inventory of hazardous chemical usage was conducted early in 1995 for calendar year 1994 (CY94). The inventoried chemicals included radionuclides, ODSs, and the SARA, Section 313, Toxic Chemical List. A Toxic Release Inventory (TRI), NESHAP notification for radionuclides, and associated annual reports will be submitted to the EPA through DOE. To date, the 1994 emissions are in compliance with applicable standards.

\subsubsection{Clean Water Act (CWA)}

The CWA sets forth goals to control pollutants discharged to U.S. surface waters. The CWA also provides for the NPDES permit program and the Spill Prevention Control and Countermeasures (SPCC) Plan. The EPA and NMED are both responsible for compliance with the CWA. EPA, Region VI, administers the NPDES permit for SNL/NM, whereas NMED administers surface and near-surface discharge regulations and RCRA groundwatermonitoring regulations. Sanitary sewer regulations are based on federal pretreatment standards and are promulgated by the City of Albuquerque.

SNL/NM has six waste-water discharge permits from the City of Albuquerque for sanitary sewer discharges and has resolved past minor violations of the permits with the City. In 1994, five violations of two City permits were determined by 24-hour composite sampling. Oil and grease concentrations exceeded the Permit 2069A-2 limit by 65 milligrams per liter (mg/L). Permit 2069H-2 limits were exceeded for oil and grease by $35 \mathrm{mg} / \mathrm{L}$, nickel (Ni) by 25.3 $\mathrm{mg} / \mathrm{L}$, and lead $(\mathrm{Pb})$ by $0.48 \mathrm{mg} / \mathrm{L}$ and $0.76 \mathrm{mg} / \mathrm{L}$. The two oil and grease violations were addressed by resampling, which showed that concentrations were within permit limits. To address the $\mathrm{Ni}$ violation, $\mathrm{Ni}$ test kits were ordered for testing of $\mathrm{Ni}$ and copper $(\mathrm{Cu})$ at the center test point between the $\mathrm{Pb}$ and lag columns so that decisions can be made concerning the effluent before a possible excursion can occur. Though elevated $\mathrm{Pb}$ levels had never been detected in any previous sampling events, it was conservatively assumed that a sink which bypassed the $\mathrm{Cu}$ recovery system contributed to the two $\mathrm{Pb}$ violations, and the sink was removed. DOE received environmental awards from the City of Albuquerque for five of the waste-water discharge permits held jointly with SNL/NM for disposal of waste-water into the City sewer system. 
Two surface impoundments have an NMED-approved discharge plan and there are 67 septic tanks at SNL/NM (SNL 1995a), nine of which remain active. NMED has ruled that several categories of low-volume and/or clean waste-water surface discharges require no discharge plans.

On October 1, 1992, SNL/NM submitted an NPDES individual permit application for its industrial discharges. Response from EPA has not yet been received; however, the stormwater pollution prevention plan is scheduled for implementation by December 1996. SNL/NM has also submitted two Notices of Intent to Discharge (NOIs) for construction storm-water discharges. One NOI was submitted on January 24, 1994, for construction of the Technology Support Center, and the other was submitted on September 19, 1994, for construction of the RMSEL.

In 1994, SNL/NM reported 15 environmental occurrences to DOE. Of these 15 occurrences, six were releases of an oil or nonhazardous petroleum product. There were six releases of potable water onto the ground, one discovery of a hazardous chemical release in a groundwater monitoring well, and one release of acid. There was one reportable occurrence that violated the New Mexico Hazardous Waste Management Regulations. Of the 15 reportable occurrences, 13 were liquid releases. Of these 13 liquid releases, 3 were between 5 and 100 gallons (gal.) and 10 were over 100 gal.

\subsubsection{Safe Drinking Water Act (SDWA)}

The SDWA is the legislative vehicle designed to protect human health by regulating the discharge of nontoxic and toxic pollutants into both groundwater and surface water sources by residential, municipal, and industrial sources. The goal of the Act is to preserve the quality of the nation's groundwater for agricultural and drinking water use.

Individual states are given responsibility by EPA for developing programs and procedures necessary to ensure that the quality of the groundwater meets the standards set by EPA. States set standards for the allowable concentrations of pollutants in surface discharges and requirements for pre-notifying, monitoring, and reporting discharges.

Individual states can elect to accept primacy of the regulations only if the state's regulations are stricter than the federal standards. Since New Mexico's regulations must be no less stringent than those set by the EPA, the SDWA standards still apply to SNL/NM.

\subsubsection{Toxic Substances Control Act (TSCA)}

The TSCA, administered by the EPA, regulates the manufacture, distribution, use, handling, and disposal of certain toxic chemicals and materials, including polychlorinated biphenyls (PCBs) and asbestos. It also requires testing and regulation of all new chemical substances, as well as regulation of some currently existing substances known or suspected to have harmful health and environmental effects. At SNL/NM, compliance with TSCA primarily involves regulation of $\mathrm{PCBs}$ and asbestos. 
All electrical distribution equipment found to contain greater than or equal to 50 parts per million (ppm) PCBs is being scheduled for removal and disposal. The time required to remove this equipment is estimated to be 3 to 5 years (yr). As of December 31, 1994, there were 9 nonelectrical distribution items and 40 electrical distribution items remaining in service that have PCB concentrations over $50 \mathrm{ppm}$. Five of the items are greater than or equal to 500 $\mathrm{ppm}$. This is a $27 \%$ decrease in the number of items containing greater than or equal to 50 ppm PCBs at SNL/NM. During 1994, approximately 5400 kilograms of PCB waste were shipped from SNL/NM for disposal during 1994.

The SNL/NM PCB program generates an annual report by July 1 , as required by TSCA, regarding all activity within the program for the past calendar year (Szklarz 1995). The PCB program at SNL/NM is on an overall decreasing activity trend as the total number of PCBcontaining items at SNL/NM approaches zero.

The Non-Facilities Asbestos program at SNL/NM handles collection, packaging, storage, and disposal for all nonfacilities asbestos waste (e.g., gloves, fume hoods, and ovens) under the requirements set forth by TSCA. The Facilities Asbestos program focuses mainly on structure abatement and includes primarily floor tiles and insulation. Approximately 1858 kilograms $(\mathrm{kg})$ of non-facilities and $14,545 \mathrm{~kg}$ of facilities asbestos waste were disposed of in 1994 .

\subsubsection{Federal Insecticide, Fungicide, and Rodenticide Act (FIFRA)}

EPA-registered pesticides are applied at SNL facilities. These pesticides are applied by an EPA-certified applicator. SNL/NM retains records of the quantities and types of pesticides that are used as well as Material Safety Data Sheets (MSDSs) for each pesticide.

\subsubsection{Endangered Species Act (ESA)}

The ESA provides for protection of threatened and endangered species of flora and fauna. Where applicable, this act requires consultations with the U.S. Fish and Wildlife Service on listed or proposed species and critical habitats. Consultations are also required with the New Mexico Game and Fish Department and the New Mexico Department of National Resources to satisfy state procedures for fauna and flora protection.

Several surveys for threatened, endangered, and sensitive species and habitats were also conducted in 1994 to help fulfill the policy objectives of NEPA and provide information on the environmental consequences that must be addressed in the NEPA process. The surveys look not only for the presence of species but also for their critical habitat. There are no federallisted threatened or endangered species known to occur within KAFB. There are, however, New Mexico-listed endangered plants that occur within KAFB. 


\subsubsection{Cultural Resources Acts}

Cultural resources management at SNL/NM is required under acts such as the National Historic Preservation Act (NHPA), the Archaeological Resources Protection Act (ARPA), and the American Indian Religious Freedom Act (AIRFA). Several surveys for cultural resources were conducted in 1994 to help fulfill the policy objectives of NEPA and provide information on the environmental consequences that must be addressed in the NEPA process. SNL/NM integrates cultural resources management into the NEPA program. It is DOE's policy that NEPA review is required for all DOE actions potentially affecting the environment; thus, even actions that are classified as categorical exclusions are reviewed for impacts on cultural resources, among other things. (See Section 3.5 for further information on NEPA activities).

\subsubsection{Executive Orders (EOs)}

Executive Orders 11988, Floodplain Management, and 11990, Protection of Wetlands, apply to NEPA-related activities and require evaluation of the potential effects of actions taken in floodplains and wetlands. These executive orders are coordinated with other NEPA review requirements at SNL/NM and both are addressed in NEPA documents where relevant to proposed actions.

\subsection{AUDITS AND APPRAISALS}

SNL/NM operations are routinely subjected to audits by external regulatory agencies as well as inspections by internal organizations. Table $2-1$ lists the external appraisals conducted in 1994. One internal independent audit was performed in 1994; the Environmental Programmatic and Compliance Appraisal began on October 10 and was completed on November 4 (SNL 1994a).

\subsection{CURRENT ISSUES AND ACTIONS}

SNL/NM strives to achieve full regulatory compliance with environmental requirements. Ongoing self-assesments of compliance status continue to identify compliance issues. Resolution of these issues is coordinated with regulatory agencies to ensure that they are addressed.

\subsubsection{Air Quality Compliance}

AQCR \#41, Operating Permits - AQCR \#41 is the implementation of the CAAA, Title V, State Operating Permit Program, in Albuquerque/Bernalillo County. AQCR \#41, with an effective date of March 13,1995, requires all existing major sources to apply for an operating permit by January 31,1996 . A major source is defined as a facility which emits or has the potential to emit 100 or more tons per year of any criteria pollutant or 10 tons or more per year of any hazardous air pollutant (HAP), or 25 tons or more per year of any combination of HAPs. 
Table 2-1. 1994 Audits and Appraisals

\begin{tabular}{|c|c|c|c|}
\hline Appraising Agency & Title & Begin & End \\
\hline $\begin{array}{l}\text { U.S. Department of } \\
\text { Energy/Albuquerque } \\
\text { (DOE/AL), Health } \\
\text { Protection Division }\end{array}$ & $\begin{array}{l}\text { Investigation of Air Quality } \\
\text { Concern at the BDM Buena } \\
\text { Vista Building, Sandia National } \\
\text { Laboratories/New Mexico } \\
\text { (SNL/NM) }\end{array}$ & $02 / 02 / 94$ & $03 / 22 / 94$ \\
\hline $\begin{array}{l}\text { DOE/AL, Environmental } \\
\text { Protection Division }\end{array}$ & Waste Moratorium, SNL/NM & $04 / 25 / 94$ & $05 / 06 / 94$ \\
\hline $\begin{array}{l}\text { New Mexico Environment } \\
\text { Department }\end{array}$ & $\begin{array}{l}\text { Hazardous Waste Management, } \\
\text { SNL/NM }\end{array}$ & $05 / 03 / 94$ & $05 / 03 / 94$ \\
\hline $\begin{array}{l}\text { U.S. Department of } \\
\text { Energy/Nevada Operations } \\
\text { Office, Waste } \\
\text { Management Division }\end{array}$ & $\begin{array}{l}\text { Technical Audit (Low-Level } \\
\text { Waste) of Sandia National } \\
\text { Laboratories, SNL/NM }\end{array}$ & $10 / 03 / 94$ & $10 / 07 / 94$ \\
\hline $\begin{array}{l}\text { Klenvled, Peat, Marwick, } \\
\text { Goerdler (KPMG) }\end{array}$ & $\begin{array}{l}\text { Fiscal Year } 1994 \text { Waste } \\
\text { Management Funds, SNL/NM }\end{array}$ & $11 / 07 / 94$ & $12 / 09 / 94$ \\
\hline $\begin{array}{l}\text { U.S. Department of } \\
\text { Energy/Headquarters, } \\
\text { Office of Environmental } \\
\text { Audit }\end{array}$ & $\begin{array}{l}\text { Draft Routine Environmental } \\
\text { Audit of the SNL/NM, } \\
\text { Albuquerque, NM }\end{array}$ & $12 / 05 / 94$ & $12 / 16 / 94$ \\
\hline
\end{tabular}

Based on the actual releases from the steam plant (Building 605) and the inventory of all standby generators and boilers, SNL/NM is a major source under Title V of the CAAA for nitrogen oxides $\left(\mathrm{NO}_{\mathrm{x}}\right)$. A strategy is being developed for compliance with the State Operating Permit Program regulation in AQCR \#41. Under AQCR \#41, SNL/NM must submit an application for the required operating permit by January 31, 1996.

AQCR \#37 (40 CFR 82). Stratospheric Ozone Protection - AQCR \#37 requires recovery and recycling of ODSs. It also requires certification for the recovery and recycling equipment used and personnel who perform the tasks. A DOE EH-24 audit conducted late in CY94 revealed that SNL/NM did not have an adequate corporate-wide plan to address ODS management. Procedures are being written and revised by the line organization to address any potential noncompliance issues. In addition to the certification program, all associated recordkeeping will be improved. 
AQCR \#20, Permit Revision for Emergency Diesel Generators (Building 862) - The current permit (\#150) for the emergency generators in Building 862 does not adequately address the operational needs of the generator plant. The monthly allowable operating hours per generator (4 hours [hr]) do not allow for emergencies beyond routine maintenance of the generators. A request to the City of Albuquerque Air Pollution Control Division for the modification of Permit \#150 has been made through the DOE office. A proposal of 480 hours per year for all of the generators was submitted to the City on February 16, 1995. In addition, other standby generators outside Building 862 will be reviewed for the AQCR \#41 application.

AQCR \#24, Variance for SMERF Testing in Compliance with AQCR \#5 - The Smoke Emission Reduction Facility (SMERF) had problems in complying with the opacity standard (AQCR \#5) for visibility. The facility was designed to reduce the impact to air quality in the area from burn tests of small objects (the smaller objects had been tested in the open-burn fire pool in the past). The City has granted SNL/NM a 1-yr variance that expires August 9, 1995, to resolve the visibility issue.

\subsubsection{Chemical Waste Landfill}

The annual groundwater monitoring report for the CWL was submitted to state and federal regulators on March 1, 1994. The March 1, 1995, report is in progress.

\subsubsection{Landfill Disposal Restrictions and Toxicity Characteristic Leaching Procedures (TCLPs)}

In 1984, Congress amended RCRA by imposing a schedule for restrictions on the land disposal of hazardous waste. These restrictions are referred to collectively as LDRs. On May 8, 1990, the final LDRs were implemented, forbidding the land disposal of hazardous waste that does not meet prescribed treatment standards. However, due to a nationwide absence of mixed waste (MW) treatment and disposal facilities, the EPA granted a National Capacity Variance that delays the implementation of most LDRs for MW. Analytical procedures and the associated regulatory changes have increased the volume and complexity of RCRA-regulated waste generated by SNL/NM.

\subsubsection{Hazardous Waste Fees}

During the first quarter of CY92, the NMED held public meetings concerning setting fees to provide for oversight of hazardous waste programs. The fees were to be payable to NMED, and were to be based on the volume of generated hazardous waste and the number of hazardous waste management units at a facility. The fees were adopted in 1993 and were imposed in CY94. The total fee for SNL/NM in CY94 was $\$ 35,000.00$. 


\subsubsection{Mixed Waste Authority}

The State of New Mexico was granted regulatory authority for MW under RCRA on July 25 , 1990. As stated in Section 2.1.2, in August 1990, SNL/NM submitted a RCRA Part A permit application to NMED for the storage and limited treatment of $\mathrm{MW}$ ( $\mathrm{pH}$ neutralization, compaction, solidification, and shredding/baling). In October 1992, a permitting strategy in the form of a Letter Agreement was sent to NMED for submitting the SNL/NM MW Part B permit application. The Part B permit application was submitted to NMED on November 8, 1992, and the first amendment was submitted August 26, 1993. An updated SNL/NM MW Part A permit application was also submitted in August 1993. A second amendment was sent to NMED in January 1995.

\subsection{ENVIRONMENTAL PERMITS}

As part of its commitment to full compliance with all applicable environmental laws and regulations, SNL/NM holds several environmental permits. Table 2-2 lists the current environmental permits and registrations issued to SNL/NM and those that are under review by various agencies. Besides these environmental permits, notifications were given to the City of Albuquerque regarding asbestos removals (NESHAP, Subpart M). Also, several projects were evaluated for applicability of NESHAP, Subpart $H$, to facilities in TA-I and TA-III.

\subsection{U.S. DEPARTMENT OF ENERGY TIGER TEAM ASSESSMENT SUMMARY}

DOE established teams of Environment, Safety, and Health (ES\&H) experts ("Tiger Teams") to inspect the various DOE laboratories for compliance with federal, state, and local environmental and safety regulations, permit agreements, DOE orders, best management practices, and internal laboratory requirements. A DOE Tiger Team assessment of the ES\&H operations at SNL/NM was conducted from April 15 through May 24, 1991.

The Tiger Team audit identified 382 environmentally related findings concerning issues such as waste characterization and management, training, and compliance issues for off-site treatment, storage, and disposal facilities (TSDFs); radioactive and mixed waste storage, characterization, and tracking; and other potential noncompliances with DOE orders. Additionally, there were findings concerning groundwater monitoring, sampling, well/borehole closure, UST management, and ER activities. Other deficiencies noted were in air quality monitoring, surface-water protection, groundwater protection, waste minimization, records management, radiological release control, and NEPA activities.

In response to the Tiger Team findings, DOE and SNL prepared an action plan. The draft action plan provided a formal written response to each of the findings cited in the Tiger Team report and presented plans, schedules, and estimated costs for correcting the identified deficiencies. The Final Action Plan to Tiger Team was approved on February 28, 1992 (SNL 1992b). The Consolidated Final Action Plan to Tiger Team (1992c), which combines the SNL/NM and SNL/California findings, was approved on October 1, 1992, and is the plan currently followed by SNL/NM. 
Table 2-2. Summary of Environmental Permits and Registrations

Permit Type and/or Facility Name Location/Building Permit Number Issue Date Expiration Date Regulatory Agency

1. Waste-Water Discharge Permits

General

General

General

$\stackrel{N}{N}$

Microelectronics Development Laboratory (MDL)

Advanced Manufacturing Process Laboratory

General

General
WW001 station manhole at Tijeras Arroyo, south of TA-IV

WW004 station manhole, 2069 D-3 TA-I/Bldg. 841 SE

WW006 station manhole, east of KAFB sanitary

Lagoons

WW007 station manhole TA-I/Bldg. 858

WW009 station manhole,

WW008 station manhole at Tijeras Arroyo, south of TA-II

WW011 station manhole, north of TA-III (includes TA-III, TA-V, and Coyote Test Area sewer lines)

$2069 \mathrm{~K}$
2069 A-2 $\quad$ (NA) $\quad 02 / 01 / 97 \quad$ City of Albuquerque

Permit terminated City of Albuquerque by the City

2069 F-2 $\quad$ (NA) 02/01/97 City of Albuquerque

2069 G-2 (NA) Permit extended City of Albuquerque by the City

$2069 \mathrm{H}-2 \quad$ (NA) $\quad 02 / 01 / 97 \quad$ City of Albuquerque

TA-I/BIdg. 878

$2069 \mathrm{I}-2 \quad$ (NA) $\quad 02 / 01 / 97 \quad$ City of Albuquerque

(NA)

Permit extended by the City 
Table 2-2. Summary of Environmental Permits and Registrations (Continued)

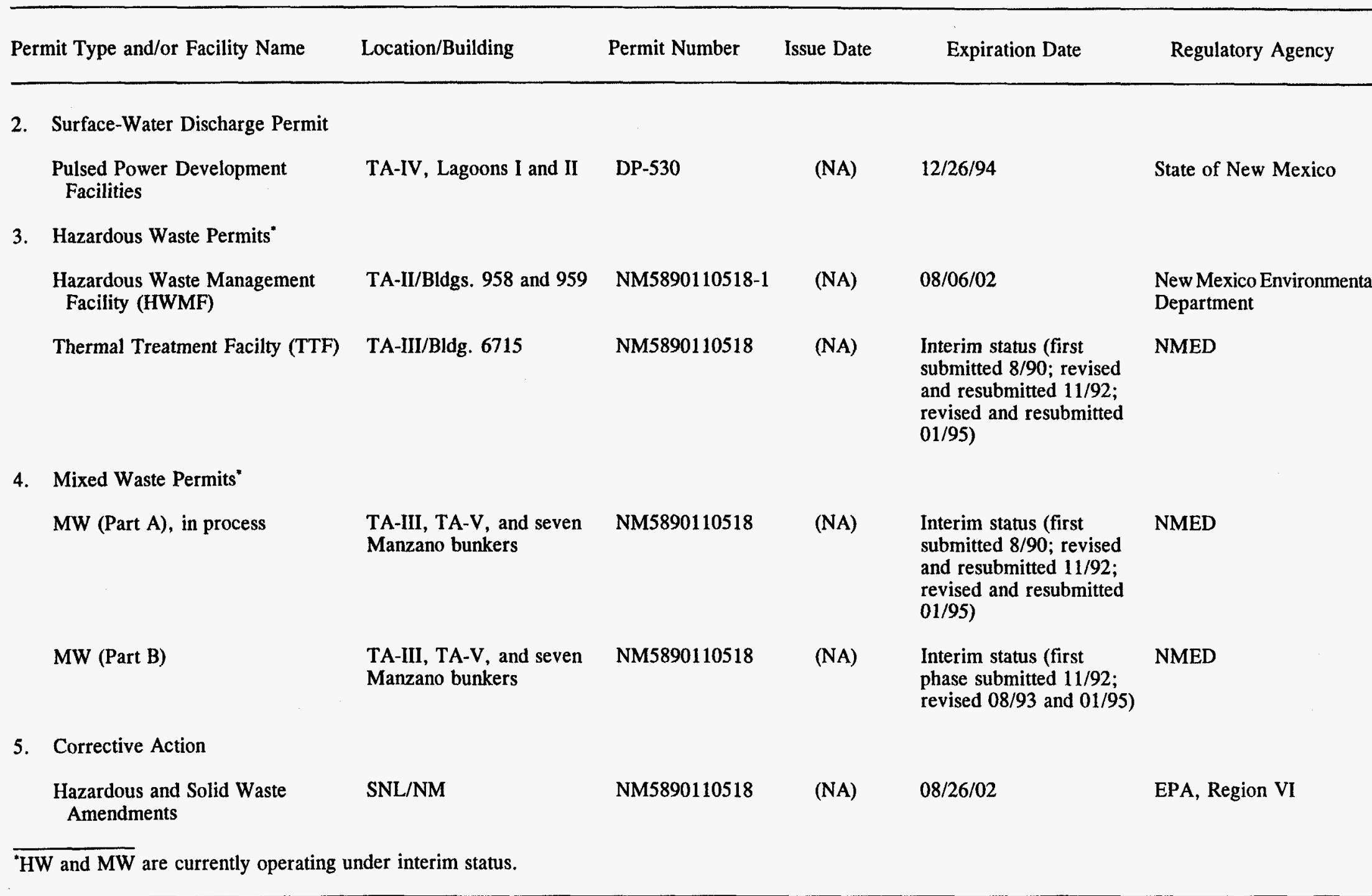


6. 1994 Open Burn Permits

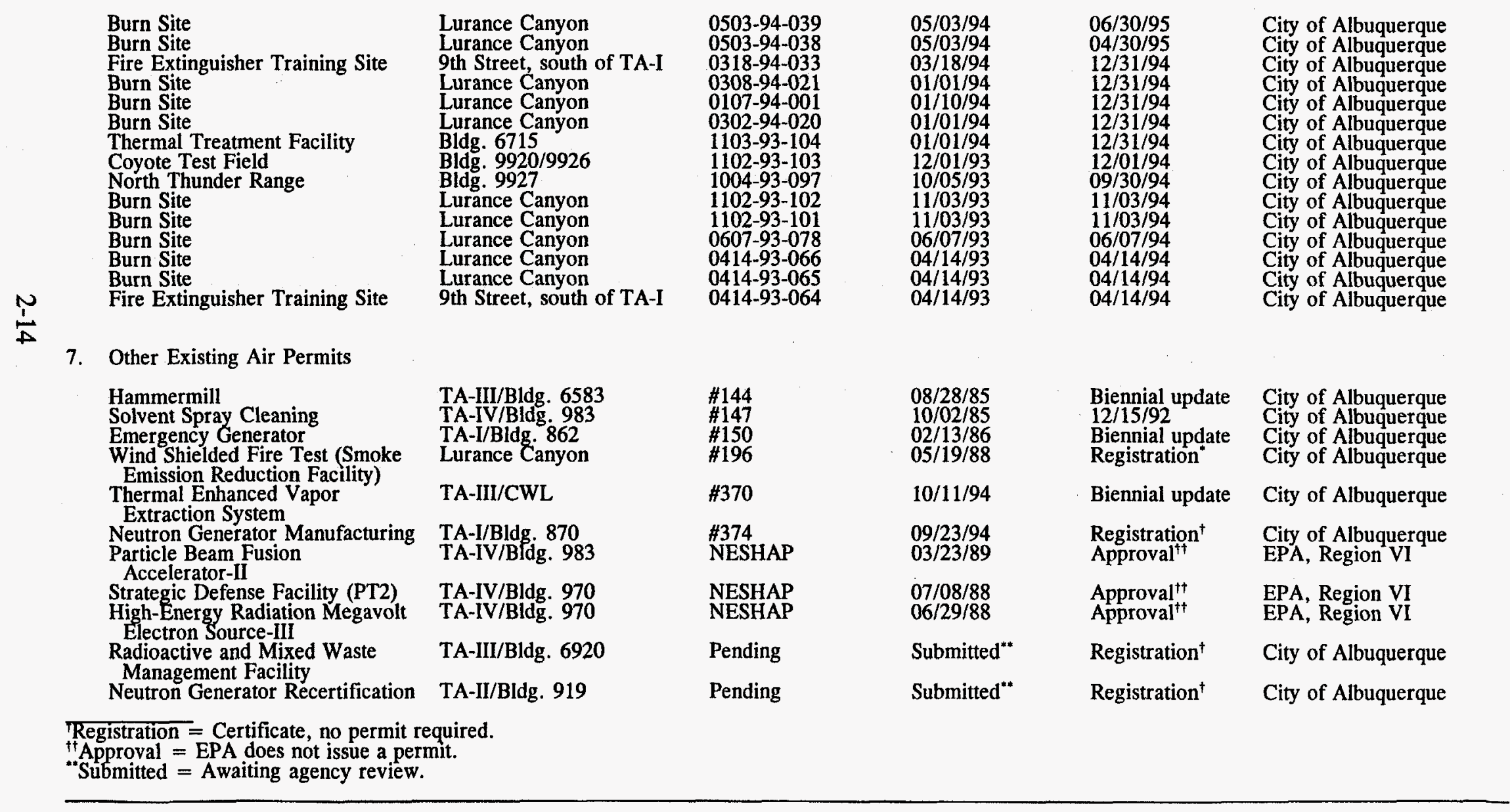


The status of corrective actions (CAs) is monitored and tracked in the Sandia Issues Management System (SIMS+) database, managed by the Appraisal Management Department. CA status may be "open," meaning that work continues on one or more tasks of the CA, "completed," meaning that all tasks have been completed by SNL/NM, or "closed," meaning that all completed tasks have been verified by DOE (or in some cases, by SNL/NM).

Completion of a CA by SNL/NM requires accomplishing the necessary activities to ensure that the deficiencies identified in the corresponding finding have been satisfactorily addressed. This may or may not require satisfying each individual milestone contained in the final action plan; however, any deviations from the final action plan undergo a quality review to ensure that the finding has been appropriately addressed (SNL 1992c). This includes a quality review of the evidence submitted by owners. DOE/Albuquerque has delegated authority to SNL to close out Priority 2, 3, and 4 CAs, whereas DOE/Headquarters still retains closure authority for Priority 1 findings.

Table 2-3 summarizes the status of CAs for each year since the Tiger Team assessment. Activities to complete several CAs have been postponed pending implementation of 10 CFR 835 which will address and complete these CAs at a later date. All other CAs are addressed on a regular basis.

Table 2-3. Status of SNL/NM Corrective Actions

\begin{tabular}{ccc}
\hline Year & Completed & Closed \\
\hline 1991 & 0 & 0 \\
1992 & 50 & 3 \\
1993 & 43 & 29 \\
1994 & $\underline{42}$ & $\underline{60}$ \\
Total & 135 & 92 \\
\hline
\end{tabular}




\subsection{ENVIRONMENTAL PROGRAMS INFORMATION}

It is the policy of the U.S. Department of Energy (DOE) and Sandia National Laboratories/New Mexico (SNL/NM) to conduct operations in an environmentally responsible manner and in compliance with applicable environmental standards. SNL/NM maintains a variety of environmental programs to implement these laws and regulations and enhance the quality of the environment. This chapter describes SNL/NM activities conducted in 1994 to remediate sites contaminated in the past, to manage hazardous, radioactive, mixed, and other wastes, to comply with environmental protection requirements, and to respond to releases and environmental incidents. Other environmental programs at SNL/NM are terrestrial surveillance, air quality surveillance and emissions monitoring, water monitoring, and groundwater monitoring. These programs are addressed in detail in following chapters.

\subsection{ENVIRONMENTAL RESTORATION PROJECT}

The Environmental Restoration (ER) Project is a phased DOE project to identify, assess, and remediate past spill, release, or disposal sites at all DOE facilities including SNL/NM.

The initial identification of sites at the Albuquerque location was completed in 1987. The installation assessment report identified 117 sites that would require further evaluation (DOE 1987). Since completion of the installation assessment report, additional sites have been identified and the number of potential release sites at Albuquerque now totals 183 (SNL 1994b). Many of these sites are being, or will be, proposed to the DOE and U.S. Environmental Protection Agency (EPA) for No Further Action (NFA) status based on the determination that they are not contaminated due to past activities.

The potential release sites identified in the installation assessment report and subsequent evaluations are grouped together within geographic and event-related boundaries. These groups of release sites are called Operable Units (OUs) for budget development and project tracking purposes. Appendix B lists the ER Project sites and identifies the specific potential release sites that are assigned within an individual $O U$.

The assessment and remediation of potential release sites identified by the ER Project at SNL/NM are being monitored by the EPA as provided for by the Hazardous and Solid Waste Amendments of 1984 (HSWA) module of the Resource Conservation and Recovery Act (RCRA) Part B Operating Permit. Section 3004(u) of RCRA requires investigation of all past and present Solid Waste Management Units (SWMUs) with a potential for release of hazardous waste or hazardous constituent(s). During 1994, assessment efforts continued at the following sites and areas: the Chemical Waste Landfill (CWL); the Mixed Waste Landfill (MWL); Technical Area I (TA-I), TA-II, TA-III, and TA-V; septic tanks and drainfields; the Liquid Waste Disposal System (LWDS); former storage tank sites; Tijeras Arroyo; Central Coyote Field; Kauai Test Facility; Tonopah Test Range; Southwest Test Areas; Foothills Test Area; Canyons Test Area; Salton Sea; and remote facilities. Voluntary Corrective Measures (VCMs) have been completed at several ER sites, and several more VCMs are planned for fiscal year 1995 (FY95). 


\subsection{UNDERGROUND STORAGE TANK (UST) MANAGEMENT}

USTs at SNL/NM are managed in accordance with State of New Mexico regulations. The New Mexico UST regulatory program has been approved by the EPA, Region VI, in accordance with Title 40, Code of Federal Regulations, Part 281 (40 CFR 281). The number of active USTs at SNL/NM decreased from seven to five in 1993, and activities to address these two inactive tanks continued in 1994.

UST 6587-2 was permanently closed by removal in December 1993 and no soil contamination was found beneath the tank. A release was detected under the fuel dispensing island. On February 16, 17, 21, and 22, 1994, IT Corporation conducted an on-site investigation (OSI) to assess the soil conditions beneath the UST dispenser. Five soil borings were completed during the OSI. The first soil boring (referred to as the central boring) was located at the point of highest known contamination. Perimeter borings were located approximately 39 feet (ft) to the southwest, northwest, southeast, and northeast. Soil samples were taken every $5 \mathrm{ft}$ throughout the entire depth of the central boring and every $10 \mathrm{ft}$ throughout the perimeter borings. Each sample was field screened for aromatic hydrocarbon vapor concentrations. Indication of contamination by petroleum compounds above the New Mexico Environmental Improvement Board (NMEIB) UST regulation limit of 100 parts per million (ppm) was found only in the central boring. The two deepest samples from each borehole were submitted for laboratory analysis. Complete analytical results are in the March 1994 OSI report for UST 6587 (IT 1994a).

UST 970-1, a 1000-gallon (gal.) diesel tank, was taken out of service in December 1993 and removed in December 1994. No indication of any leak or any contamination was observed. One soil sample was taken in close proximity to the tank and a second soil sample was taken from under the piping. Petroleum hydrocarbons were not detected in either sample.

\subsection{SPILL PREVENTION CONTROL AND COUNTERMEASURES (SPCC) PLAN}

Spill control activities at SNL/NM are managed using several orchestrated plans and programs. SPCC plans for SNL/NM (Fink and Park 1992), the Tonopah Test Range, and SNL/California (SNL/CA) are augmented at SNL/NM by the Oil Spill Contingency Plan (Fink and Park 1993a) and the Hazardous and Radioactive Materials SPCC Plan (Fink and Park 1993b).

Oil-spill control activities at SNL/NM are coordinated using the SPCC Plan (CDM 1990, 1993). This plan was prepared in accordance with 40 CFR 112. The 3-year (yr) rewrite, required by 40 CFR 112, was completed in 1992 and approved by the DOE (CDM 1993). The next 3 -yr revision is in progress at this time. 
Activities for 1994 included the following:

- Annual revision of the SPCC Plan (CDM 1990, 1993).

- Annual revision of the Oil Spill Contingency Plan (required by 40 CFR 112) (Fink and Park 1993a).

- Annual inspection of the regulated facilities for SNL/NM.

\subsection{WASTE MANAGEMENT PROGRAMS}

Waste management is the safe and effective management of active and standby facilities and the treatment, storage, and disposal of radioactive, hazardous, and mixed wastes. The following sections include summary descriptions of major waste management programs and activities.

\subsubsection{Hazardous Waste and the Resource Conservation and Recovery Act}

Chemical wastes generated by SNL/NM research and development (R\&D) activities are collected from generator locations, segregated according to U.S. Department of Transportation (DOT) hazard class, and transported to the RCRA-permitted Hazardous Waste Management Facility (HWMF) for storage. At the HWMF, the wastes are consolidated and packaged according to DOT and EPA requirements. Packaged wastes are transported by EPA-permitted carriers to EPA-permitted treatment, storage, and disposal facilities (TSDFs) or recyclers for final disposition.

All RCRA-regulated wastes generated by SNL/NM (except mixed waste [MW]) are transported off-site for recycling or disposal at EPA-permitted TSDFs.

Table 3-1 lists the EPA-permitted commercial carriers used to transport SNL/NM hazardous waste during 1994. Table 3-2 lists the permitted TSDFs, recyclers, and waste treatment methods employed at each facility.

During calendar year 1994 (CY94), a total of 691,693 kilograms (kg) of waste was managed by SNL/NM's Waste Operations Department. It included 86,369 $\mathrm{kg}$ of RCRA-regulated hazardous waste and $605,324 \mathrm{~kg}$ of solid and recycled materials. In CY94, a total of 29,780 items were collected from SNL/NM generators, packaged into 4,224 containers, and sent to TSDFs and recyclers. The volume of RCRA hazardous waste processed in CY94 decreased from that reported in CY93; however, the quantity of solid and recycled material increased. The volume was influenced by the KAFB solid waste landfill closure, ER Project remediation activities, and recycling operations.

SNL/NM's Thermal Treatment Facility (TTF) was issued a treatment permit in November 1994 by NMED. The TTF was constructed to thermally treat residual explosives generated at SNL/NM. In CY94, the TTF did not treat any residual explosive waste. 
Table 3-1. EPA-Permitted, SNL/NM Hazardous Waste Transporters Used in Calendar Year 1994

1. Rinchem Company, Inc.

2. Safety-Kleen Corp.

3. Sandia National Laboratories

4. USPCI/Wills Trucking
5. Custom Environmental Transport

6. Chem Waste

7. Hittman Transport

8. Evergreen

Note: Identification of these companies is not necessarily an endorsement of their services by SNL/NM.

Table 3-2. Waste Disposal Facilities Used by SNL/NM in Calendar Year 1994

Disposal Facility

Treatment

1. USPCI (Grassy Mountain, UT)

2. ENSCO, Inc.

3. Rollins Env. Svcs., Inc. (LA)

4. Rollins Env. Svcs., Inc. (TX)

5. Inmetco

6. MERECO

7. BDT, Inc.

8. Kirtland Landfill

9. Kirtland Explosive Ordnance Disposal (EOD) Range

10. Safety-Kleen

11. Kinsbursky Bros.

12. Evergreen

13. Englehard

14. ECDC

15. NSSI

16. Lighting Resources, Inc.

17. SALESCO
Stabilization, Encapsulation, and Landfill

Incineration

Incineration

Incineration

Metals Recycling

Metals Recycling

Hydrolysis of Reactive Metals

Non-RCRA/Nonenvironmentally Hazardous

Trash

Open Detonation/Open Burn

Solvent Recycling

Metal Recycling

Oil Recycling

Precious Metal Recycling

Non-RCRA Solid Waste

Treatment of Reactives

Fluorescent Light Recyclers

Ballast and Capacitor (PCB/Non-PCB) Recyclers

Note: Identification of these companies is not necessarily an endorsement of their services by SNL/NM. 


\subsubsection{Radioactive Waste}

On-site disposal of low-level radioactive waste (LLW) at SNL/NM was terminated in December 1988 as a result of a DOE order. Presently, all newly generated LLW and MW are stored temporarily aboveground at generator sites, in the TA-V High Bay Waste Storage Facility (Building 6596), or in transportation containers at the inactive TA-III disposal site. During 1994, 1886 cubic feet $\left(\mathrm{ft}^{3}\right)$ of LLW and $59 \mathrm{ft}^{3}$ of MW were accepted at the TA-III storage site. This waste consisted of material primarily contaminated with fission products, uranium, or tritium.

The Radioactive and Mixed Waste Management Facility (RMWMF) was completed in 1990. Due to changes in regulations during construction, some facility upgrades are required before operations can begin. This 6000 -square-foot $\left(\mathrm{ft}^{2}\right)$ facility will serve as a centralized packaging and storage facility for LLW and LLW-MW that meet the facility waste acceptance criteria (WAC). An environmental assessment (EA) was prepared for the RMWMF and submitted to DOE in 1990; an approval of a finding of no significant impact (FONSI) was received in April 1993. A Safety Assessment for the RMWMF also was submitted to DOE for review on March 25, 1994 (Seylar 1994). The RMWMF is scheduled to be operational in 1996.

SNL/NM does not currently generate transuranic (TRU) waste. Ultimately, the TRU waste generated at SNL/NM in the past (approximately 1 cubic meter) will be disposed of at the Waste Isolation Pilot Plant (WIPP). Currently, this TRU waste is packaged and stored at generator-controlled locations.

\subsubsection{Mixed Waste}

In January 1995, SNL/NM submitted a revised MW Part A and Part B permit application to the New Mexico Environment Department (NMED). During 1994, the following activities were in place to meet RCRA regulatory and statutory requirements for the management of MWs at SNL/NM:

- Sampling and analysis of MW as necessary to determine its regulatory status (Title 40, Code of Federal Regulations, Part 261 [40 CFR 261]).

- Inventory of MW generation and MW in storage as required by the Federal Facility Compliance Act.

- MW generator training (40 CFR 262 and 265).

In May 1994, NMED inspected the hazardous waste (including MW) management activities at SNL/NM. Four findings were detected: (1) failure to perform a hazardous waste determination, (2) exceeded allowable capacity of hazardous waste in storage at satellite accumulation area, (3) failure to provide required decontamination equipment, and (4) failure to mark containers with accumulation start dates. Some fines were assessed and paid. 
DOE conducted the two appraisals during 1994. DOE/EPD evaluated the Radioactive Material Management Area (RMMA) program in place at SNL/NM, and DOE/EH-24 evaluated the waste management (WM) and environment protection (EP) programs and the ER Project. Both evaluations identified observations for improvements.

There were five findings as a result of the DOE/EPD's RMMA audit, all of which have been corrected. The findings were (1) inadequate procedure for control of radioactive contamination at the Environmental Laboratory Building, (2) lack of a current list of MW generators, (3) lack of training for some generators, (4) improper use of "critical levels" in the ES\&H Program Document, Control of RMMAs, and (5) improper use of DOE Order 5400.5 (DOE 1990a) limits for unrestricted release. The DOE/EH-24 audit noted seven findings consisting of failures on the part of (1) SNL/NM, DOE/Kirtland Area Office (DOE/KAO), and DOE/Albuquerque (DOE/AL) to implement programs fully for the minimization of waste and pollution prevention and for the management of lead in accordance with DOE objective; (2) SNL/NM and DOE/KAO to implement all elements of an environmental as low as reasonably achievable (ALARA) program as required by DOE Order 5400.4 (DOE 1989a); (3) DOE/AL, $\mathrm{DOE} / \mathrm{KAO}$, and SNL/NM to develop and document programs, plans, and procedures fully as required by DOE Order 5400.1 (DOE 1988a) and DOE Order 5480.19 (1990b); (4) SNL/NM to have a complete and comprehensive set of formal procedures for managing and implementing the site's Ozone-Depleting Substance Management Plan for Real Property (ODS Management Plan) and the requirements of 40 CFR 82; (5) SNL/NM to fully implement an environmental training program that ensures personnel have been adequately trained; (6) SNL/NM, DOE/AL, and DOE/KAO to integrate effective mechanisms to evaluate, track, and, where needed, improve environmental programs; and (7) SNL/NM, DOE/AL, and DOE/KAO to have sufficient procedures and resources in place to ensure that all potentially significant environmental risks of projects and other actions are identified and assessed.

\subsubsection{Special-Case Waste}

In 1993, SNL/NM completed a site-wide inventory of waste including six categories of specialcase (SC) waste.

- DOE comparable greater-than-Class-C (SC-GTCC)

- Performance assessment limiting (SC-PAL)

- Uncertified or uncharacterized (SC-US)

- Noncertifiable, nontransportable TRU (SC-TRU)

- High-level, incidental (SC-HLI)

- Commercially held, DOE-owned materials (SC-COM)

No special-case waste was identified during the 1993 inventory and none has been identified since then. 


\subsubsection{Polychlorinated Biphenyl Waste}

SNL/NM continues the process of phasing out equipment containing polychlorinated biphenyls (PCBs) at the quickest rate possible. All equipment with PCBs greater than or equal to 50 $\mathrm{ppm}$ is being scheduled for replacement and disposal. As of December 31, 1994, there were 49 pieces of equipment with PCB content greater than or equal to $50 \mathrm{ppm}$ remaining in service at SNL/NM. Of the 49 pieces, five were greater than or equal to $500 \mathrm{ppm}$ PCBs.

In 1994, approximately $5400 \mathrm{~kg}$ of SNL/NM PCB-contaminated material was disposed of at off-site permitted facilities.

\subsubsection{Asbestos Waste}

Asbestos waste at SNL/NM is defined as equipment with asbestos-containing material (ACM) and asbestos waste from facilities asbestos abatement projects. The SNL/NM Waste Operations Department oversees the storage, transportation, and disposal of facilities and nonfacilities asbestos waste and equipment containing asbestos in friable form (i.e., the asbestos fibers can easily be liberated to the environment). Approximately $1,858 \mathrm{~kg}$ of nonfacilities and $14,545 \mathrm{~kg}$ of facilities asbestos waste were disposed of in 1994 .

In instances where equipment has $\mathrm{ACM}$ in nonfriable form and the equipment is still useful to $\mathrm{SNL} / \mathrm{NM}$, the items will remain in service or they will be picked up for property reapplication.

If the asbestos in ACM is in friable form, creating a health hazard, either the equipment will be properly disposed of or the asbestos will be abated from the equipment. Proper disposal consists of transporting the material to a landfill permitted to accept friable asbestos waste. The abatement option is exercised when the ACM is easily removed from an item and/or when the item is of such size that the landfill option is not a practical alternative.

\subsubsection{Pollution Prevention Program}

A formal waste-minimization and pollution-prevention (WMin/PP) awareness program was initiated in 1989 to comply with EPA regulations, DOE Orders 5400.1, 5400.3, and 5820.2A (DOE 1988a, 1988b, and 1989b), and Executive Order (EO) 12856. The latter is an important signal of the fundamental change in federal-agency environmental accountability and mandates a strong federal pollution prevention program. The SNL/NM pollution prevention program addresses waste reduction activities for all media (air, water, and solid) for nonhazardous, hazardous, mixed, and radioactive wastes and aims to foster a cradle-to-grave philosophy to conserve resources and make pollution prevention part of everyday activities.

Accomplishments in 1994 include the following:

- SNL Pollution Prevention Plan-The SNL Pollution Prevention Plan (SNL 1994c) documents the pollution prevention program for all SNL sites. The plan is a reference tool and provides programmatic guidance; it specifies strategies, activities, 
and methods employed to reduce the quantity and toxicity of waste generated at SNL. The plan was approved and signed by the Director of ES\&H, Facilities and Security Center (SNL/CA), the Director of the Environmental Operations Center (SNL/NM), the Vice-President of Laboratories Services, and the Line Implementation Working Group (LIWG) Chair.

- Pollution Prevention Team-The Pollution Prevention Team, which was formed in early CY94, is composed of two line managers as co-chairs, Pollution Prevention Site Coordinators, and staff members from line organizations. The goal of the team is to be the corporate champion for pollution prevention and to motivate, help, and enable all Sandians to incorporate pollution prevention in all activities.

- Pollution Reduction Team-The Pollution Reduction Team was formed to help the line organizations reduce waste. The team's responsibilities include promoting pollution prevention, gathering process information, evaluating processes for pollution prevention opportunities, identifying alternatives, and championing implementation of these alternatives.

- Affirmative Procurement Team-The Affirmative Procurement Team was established to develop and improve procurement to both maximize reuse and recycling and emphasize the purchase of post-consumer products. Team members are from various organizations including the pollution prevention programs at SNL/NM and SNL/CA, Lab News, Just-in-Time purchasing, construction, reapplication, and general stores at $\mathrm{SNL} / \mathrm{CA}$.

- Earth Day Festival-The First SNL/NM Earth Day Festival, held on April 22, 1994, was attended by approximately 3000 people and was coordinated with DOE and Kirtland Air Force Base (KAFB). The festival theme was "Pollution Prevention: Today's Gift for Tomorrow." There were animals (including a graffiti-erasing baboon), food, bluegrass music, and 35 displays about protecting the environment. Electrical power for the live music and public address system came from the sun via a photovoltaic trailer. During the 3-hour (hr) festival, 900 lunches were served. In the first 45 minutes (min), 800 tree saplings were given away. Over 30 volunteers were involved in festival planning and execution. For the customer focus, process management, and results-oriented process, the Earth Day Festival received a Silver Sandia President's Quality Award, the top level awarded in 1994.

\subsection{NATIONAL ENVIRONMENTAL POLICY ACT (NEPA) COMPLIANCE ACTIVITIES AND DOCUMENTATION IN 1994}

The NEPA, the nation's most comprehensive legislative and public policy statement for environmental protection, applies to all agencies of the federal government.

The Secretary of Energy's February 5, 1990, NEPA Notice (SEN-15-90), with directives intended to bring DOE into full compliance with NEPA, set in motion events that led to a 
major increase in commitment to the principles and practices underlying NEPA. New compliance and guidance procedures are being developed by both DOE and SNL/NM. These new requirements have greatly increased NEPA compliance activities.

On April 24, 1992, DOE published its NEPA regulations in the form of a final rule entitled "National Environmental Policy Act Implementing Procedures" (10 CFR 1021). This rule revoked DOE's former NEPA guidelines of December 15, 1987. In the rule, DOE promulgated its own requirements, incorporating NEPA-implementing regulations published by the Council on Environmental Quality (CEQ) as 40 CFR 1500 through 1508. The CEQ, created by the Executive Office of the President under the authority of NEPA, establishes NEPA regulations used by all federal agencies.

Supplemental Directive DOE/AL 5440.1D was issued on March 19, 1992 (DOE 1992b). DOE Order 5440.1E (DOE 1992a), issued on November 10, 1992, establishes responsibilities and procedures to implement NEPA in conformance with the new DOE NEPA regulations.

Several EOs are coordinated with NEPA review requirements and apply to NEPA-related activities. For example, EO 11988, Flood Plain Management, and EO 11990, Protection of Wetlands, contain specific requirements for federal agencies. Both are addressed in NEPA documents where relevant to proposed actions.

Compliance with environmental laws concerning cultural resources, such as the National Historic Preservation Act (NHPA), helps fulfill the policy objectives of NEPA and provides information on the environmental consequences that must be addressed in the NEPA process. Section 106 of the NHPA directs federal agencies to take into account the effects of their actions on properties listed on or eligible for the National Register of Historic Places. In support of NEPA documentation, several archaeological surveys have been completed for SNL/NM.

The Endangered Species Act provides for protection of threatened and endangered species of flora and fauna. Where applicable, this act requires consultations with the U.S. Fish and Wildlife Service on (1) listed or proposed threatened and endangered species and critical habitats, and (2) other sensitive species. Consultations are also required with the New Mexico Game and Fish Department and the New Mexico Department of Natural Resources to satisfy state procedures for fauna and flora protection.

At SNL/NM, the Risk Management \& NEPA Department administers the NEPA program. The program's responsibilities include the following activities:

- Consulting and training line organization personnel in NEPA compliance.

- Coordinating NEPA document preparation. 
- Maintaining a corporate NEPA document file.

- Reviewing and assuring the quality of NEPA documents before their submittal to the DOE.

Although only DOE has authority to decide the appropriate level of NEPA documentation, SNL/NM assists DOE by drafting the documentation for DOE approval. NEPA documents serve as vehicles for assessing potential environmental impacts of proposed federal actions and for disclosing federal activities. The process for creating and reviewing DOE NEPA documents is shown in Figure 3-1. The SNL/NM Risk Management \& NEPA Department can provide details for the EA and EIS review process.

\subsubsection{Activities}

SNL/NM provided information, including baseline data, for two programmatic EISs that are being prepared by DOE/Headquarters.

1. The DOE Nuclear Weapons Complex Reconfiguration Programmatic Environmental Impact Statement (PEIS) (DOE 1993b). This PEIS is one of DOE's most important undertakings to be handled in a NEPA document.

2. The Implementation Plan for Environmental Restoration and Waste Management Programmatic Environmental Impact Statement (DOE 1994d).

Two papers were published by the NEPA program staff in 1994 .

1. Use of Comprehensive NEPA Documents to Reduce Program Risk (NAEP 1994).

2. Integrating Pollution Prevention/Waste Minimization into the National Environmental Policy Act Process (NAEP 1994).

Several surveys for threatened, endangered, and sensitive species and habitats were conducted in 1994 to help fulfill the policy objectives of NEPA and provide information on the environmental consequences that must be addressed in the NEPA process. No federal-listed threatened or endangered species occur within Kirtland Air Force Base (KAFB); however, New Mexico-listed endangered plants occur within KAFB.

In 1994, 182 proposed actions were assigned NEPA identification (ID) numbers. Supplemental Directive DOE/AL 5440.1D requires that every action proposed by DOE/AL be assigned a NEPA ID number to facilitate NEPA compliance tracking of that action at all stages of its development and implementation (DOE 1992b). The NEPA ID number is assigned at the earliest appropriate stage, generally at the time the action is determined to warrant preparation of a NEPA Environmental Checklist (DOE 1992a). Of the 182 actions assigned identification numbers, 171 actions were submitted to DOE for review and determination. 


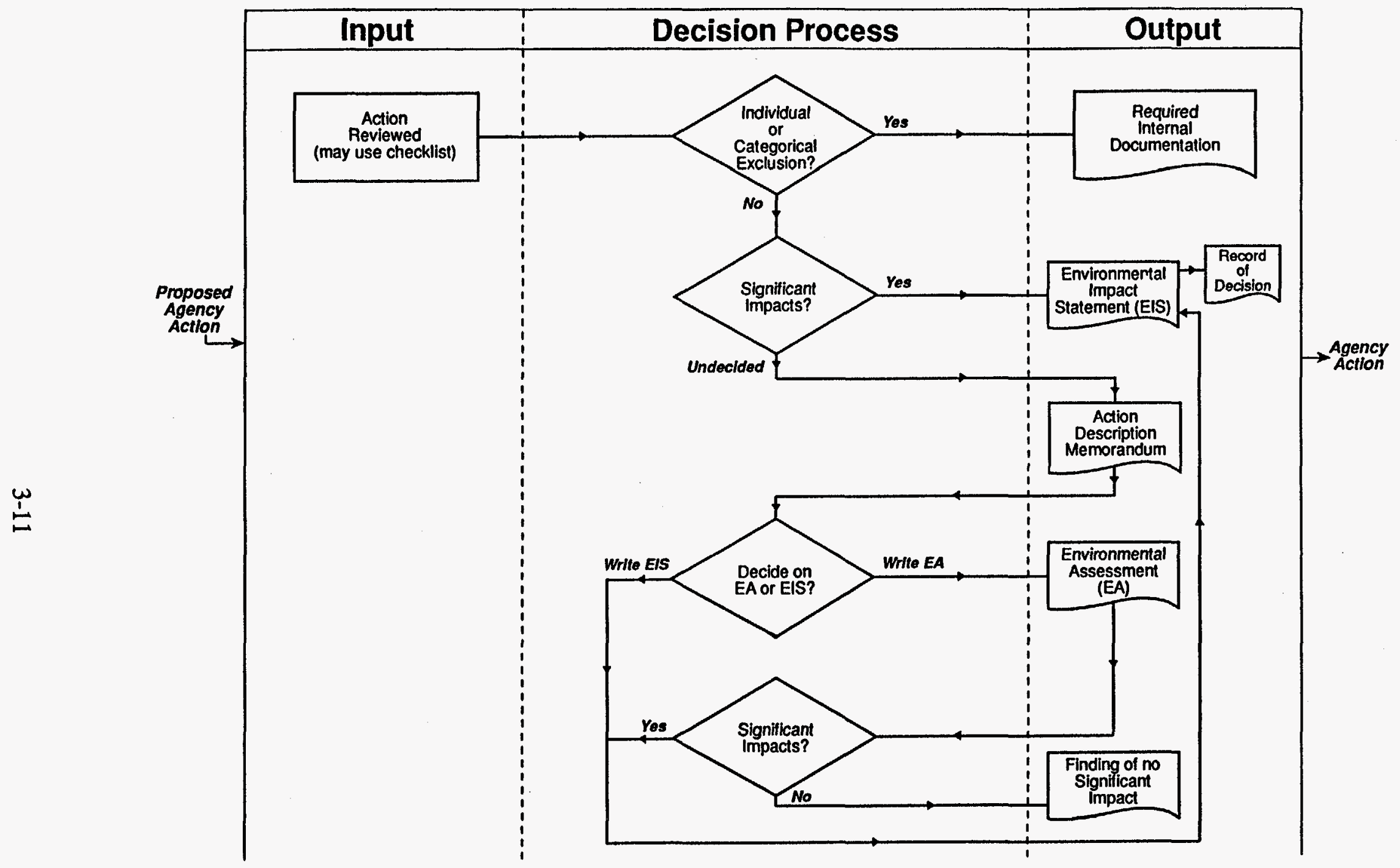

Figure 3-1. Process for Creating and Reviewing U.S. Department of Energy National Environmental Policy Act Documentation 


\subsubsection{NEPA Training and Outreach}

Professional non-SNL trainers and SNL NEPA specialists train Sandians on NEPA processes to enhance efficiency and effectiveness in complying with NEPA. SNL/NM's ES\&H Division, which publishes the ES\&H Training Catalog (SNL 1993b), offers four courses: NEPA Awareness, NEPA Executive Overview, NEPA Writing, and NEPA Implementation. The first three courses were conducted during 1994.

A 1-day in-house NEPA Executive Overview course being developed jointly by the NEPA program and the Training Department will be offered later in 1995. This course will focus on making NEPA an integral part of the regular recurring planning and management process and will replace the current NEPA Executive Overview course.

\subsubsection{NEPA Baseline Information}

Information gathering to characterize the existing environment on lands used by SNL/NM continued in 1994. The term "environmental baseline" refers to the existing physical, biological, and socioeconomic environment before it is altered ("significantly" or not) by the "proposed action" in the NEPA context. The baseline is a compendium of information that provides a framework for describing the "affected environment" as required for EISs and other NEPA-related "environmental documents."

Four baseline reports were published in 1994 through the Risk Management and NEPA Department.

1. Biological Surveys for the Sandia National Laboratories Coyote Canyon Complex Kirtland Air Force Base, Albuquerque, New Mexico (Sullivan and Knight 1994)

2. Biological Investigations of the Sandia National Laboratories Sol se Mete Aerial Cable Facility (Sullivan 1994)

3. Noise and Vibration Investigations of the Sandia National Laboratories Sol se Mete Aerial Cable Facility (Matise et al. 1994)

4. Air Quality Investigations of the Sandia National Laboratories Sol se Mete Aerial Cable Facility (Gutman and Silver 1994)

\subsubsection{Environmental Assessment Findings of No Significant Impact}

FONSIs were issued after the satisfactory completion of three EAs. The FONSI for the EA for the neutron generator/switch tube prototyping relocation was issued on April 8, 1994 (DOE 1994b). The FONSI for the EA for the Construction and Occupancy of the Robotic Manufacturing Science and Engineering Laboratory was issued on April 13, 1994 (DOE 1994c). The FONSI for the EA for General-Purpose Heat Source Safety Verification and Testing was issued on February 15, 1995 (DOE 1995). 
During 1994 there were 15 EAs under development for DOE facilities at SNL/NM for proposed actions involving SNL/NM research activities (see Table C-1 of Appendix C).

\subsection{SUMMARY OF 1994 RELEASE AND ENVIRONMENTAL INCIDENT REPORTS}

This section contains summary information about nonroutine releases of pollutants or hazardous substances. This information may be used to evaluate facility operations, waste handling programs, and emergency response programs.

\subsubsection{Summary of Release Reporting}

The following four release reporting documents are required by organizations other than SNL.

\section{Reportable Quantity (RQ) Accidental Release Reporting}

2. The Radioactive Effluent Information System/Onsite Discharge Information System (EIS/ODIS) Annual Report

3. The National Emission Standards for Hazardous Air Pollutants (NESHAP) for Radionuclides from DOE Facilities (Subpart H) Annual Report

4. Emergency Planning and Communtity Right-to-Know Act (EPCRA), Section 313, Toxic Release Inventory (TRI)

Reportable Quantity Reporting - RQ release reporting is required by the Comprehensive Environmental Response, Compensation and Liability Act (CERCLA) and SARA, Title III. CERCLA requires that any release to the environment in any 24-hr period of any pollutant or hazardous substance in a quantity greater than or equal to the RQ be reported immediately to the National Response Center (NRC) at telephone number (800) 424-8802; however, if the release is "federally permitted" under CERCLA Section 101(10)(H), it is exempted from CERCLA reporting. This reporting exemption also applies to any "federally permitted" release under SARA, Title III.

Table 3-3 contains the annual summary of RQ release reporting for SNL/NM. In 1994, two releases exceeding the $R Q$ were reported.

EIS/ODIS Reporting - DOE Order 5400.1 requires that data about radioactive effluent and on-site discharge from the previous year for all planned and unplanned releases must be reported to the Waste Information System Branch of Edgerton, Germeshausen \& Grier Corp. (EG\&G), Idaho, Inc., by April 1 each year (DOE 1988a). The EIS/ODIS report for 1994, submitted on February 24, 1995, covered all routine and nonroutine releases from SNL/NM operations. 
Table 3-3. Annual Summary of 1994 Reportable Quantity (RQ) Accidental Release Reporting

\begin{tabular}{llcccccc}
\hline $\begin{array}{c}\text { Event } \\
\text { Date }\end{array}$ & $\begin{array}{c}\text { SNL/NM } \\
\text { Location }\end{array}$ & $\begin{array}{c}\text { Hazardous } \\
\text { Material }\end{array}$ & $\begin{array}{c}\text { Quantity } \\
(\mathrm{lb})\end{array}$ & $\begin{array}{c}\text { RQ } \\
(\mathrm{lb})\end{array}$ & $\begin{array}{c}\text { Released } \\
\text { To }\end{array}$ & $\begin{array}{c}\text { NRC } \\
\text { Number }\end{array}$ & $\begin{array}{c}\text { Report } \\
\text { Date }\end{array}$ \\
\hline $06 / 01 / 94$ & $\begin{array}{l}\text { Technical } \\
\text { Area IV }\end{array}$ & Oil & $\begin{array}{c}1,000 \\
\text { gal. }\end{array}$ & Varies & Ground & 241925 & $06 / 01 / 94$ \\
$01 / 19 / 94$ & $\begin{array}{l}\text { Technical } \\
\text { Area III }\end{array}$ & $\begin{array}{c}\text { Lead } \\
\text { Acetate }\end{array}$ & 14.92 & 1.0 & Air & 217588 & $01 / 19 / 94$ \\
& & & & & & \\
\hline
\end{tabular}

NESHAP Reporting - The NESHAP standards of 40 CFR 61, Subpart $H$, for radionuclides require that an annual report from each DOE site must be submitted to the EPA by June 30 each year. The report includes the calculated effective dose equivalent (in mrem/yr) for both the maximum exposed individual and the local population.

Section 5.5 presents detailed results of the dose assessment for the public due to SNL/NM operations in 1994.

Toxic Release Inventory Reporting - The TRI report is required by EPCRA (40 CFR 372) for facilities that have a Standard Industrial Classification [SIC] code from 20 through 39 and that use listed toxic chemicals in quantities greater than 10,000 pounds per year (lb/yr) for any of the listed chemicals. Although most SNL/NM operations are not categorized within SIC codes 20 through 39, EO 12856, Federal Compliance with Right-to-Know Laws and Pollution Prevention Requirements, requires federal facilities meeting reporting thresholds to submit TRI reports under EPCRA. SNL/NM has been filing the TRI reports with DOE and the EPA since 1991 (for reporting year CY90). SNL/NM filed the CY94 TRI in June 1995.

\subsubsection{Environmental Occurrence Reporting}

In 1994, there were 15 environmental occurrences that because of their volume and/or ingredients were reported to DOE as required by DOE Order 5000.3B, Occurrence Reporting and Processing of Operations Information (DOE 1993c).

Of the 15 occurrences, six were releases of an oil or nonhazardous petroleum product. There were six releases of potable water onto the ground surface and one discovery of a hazardous chemical release in a groundwater monitoring well. There was also one release of acid (a pH excursion) at the Microelectronics Development Laboratory (MDL), Building 858, that lasted for approximately $70 \mathrm{~min}(10 \mathrm{~min}$ beyond the permit limit of $60 \mathrm{~min}$ ). There was one reportable occurrence that violated the New Mexico Hazardous Waste Management 
Regulations. This occurrence was compromised of eight violations: four related to waste storage operations, three in complying with daily operations procedures, and one related to an omission on a form required for shipment of waste to a disposal site.

Of the total 15 reportable occurrences, 13 were liquid releases. Of the 13 liquid releases, 3 were between 5 gal. and 100 gal., and 10 were over 100 gal. 


\subsection{TERRESTRIAL SURVEILLANCE}

Sandia National Laboratories/New Mexico (SNL/NM) has performed environmental radiological surveillance activities since February 1959. Calendar year 1993 (CY93) marked the first year that stable metal surveillance activities were conducted. The objectives of the radiological and stable metal surveillance activities are to detect any potential releases and/or migration of contaminated material related to on-site operations to off-site (community) locations and also to determine potential impacts (if any) of site-related activities to the off-site population and the surrounding environment. These surveillance activities also confirm the effectiveness of environmental release-control systems in place at the various technical areas (TAs).

\subsection{SURVEILLANCE LOCATIONS}

The Environmental Surveillance program staff collected soil, arroyo sediment, surface water, and vegetation samples in May and August of 1994. The sampling stations are located in three distinct areas: on the SNL/NM site, at the site perimeter, and in the surrounding community. On-site locations are near areas of known contamination or potential sources of contamination, or are in areas where contamination, if present, would be expected to accumulate. The perimeter locations are used to monitor the SNL/NM boundaries for any migration of potential site-related contamination to off-site receptors. The community locations are off-site and unrelated to SNL/NM activities. Data collected at off-site locations serve as a reference for comparison with samples collected from SNL/NM perimeter and on-site locations. Thermoluminescent dosimeters (TLDs) are used to measure ambient levels of gamma radiation. TLDs are also located on-site, around the perimeter, and off-site.

Most terrestrial surveillance locations remain essentially the same from year to year (Figures 4-1 and 4-2). Table 4-1 lists the SNL/NM terrestrial surveillance locations, specifies the types of samples collected at each location, and indicates which locations contain TLD stations. There are a total of 65 fixed sampling locations: 33 on-site (at SNL/NM), 16 distributed around the site perimeter, and 16 off-site in and around Albuquerque within a 50-mile (mi) radius of SNL/NM. New monitoring locations are added as necessary to monitor new facilities and operations, or to supplement existing data.

\subsection{SAMPLE COLLECTION AND ANALYSIS}

Environmental samples were collected and analyzed in accordance with the Quality Assurance Project Plan and operating procedures for terrestrial surveillance (SNL 1993c, 1994d). Native vegetation (grasses unless otherwise noted), soil, sediment, and surface-water samples were collected biannually: once early in the growing season (May) and once toward the end of the growing season (August). TLDs were exchanged every calendar quarter. Surface-water samples were collected by grab sampling. Total surface water (unfiltered), filtered water, and 


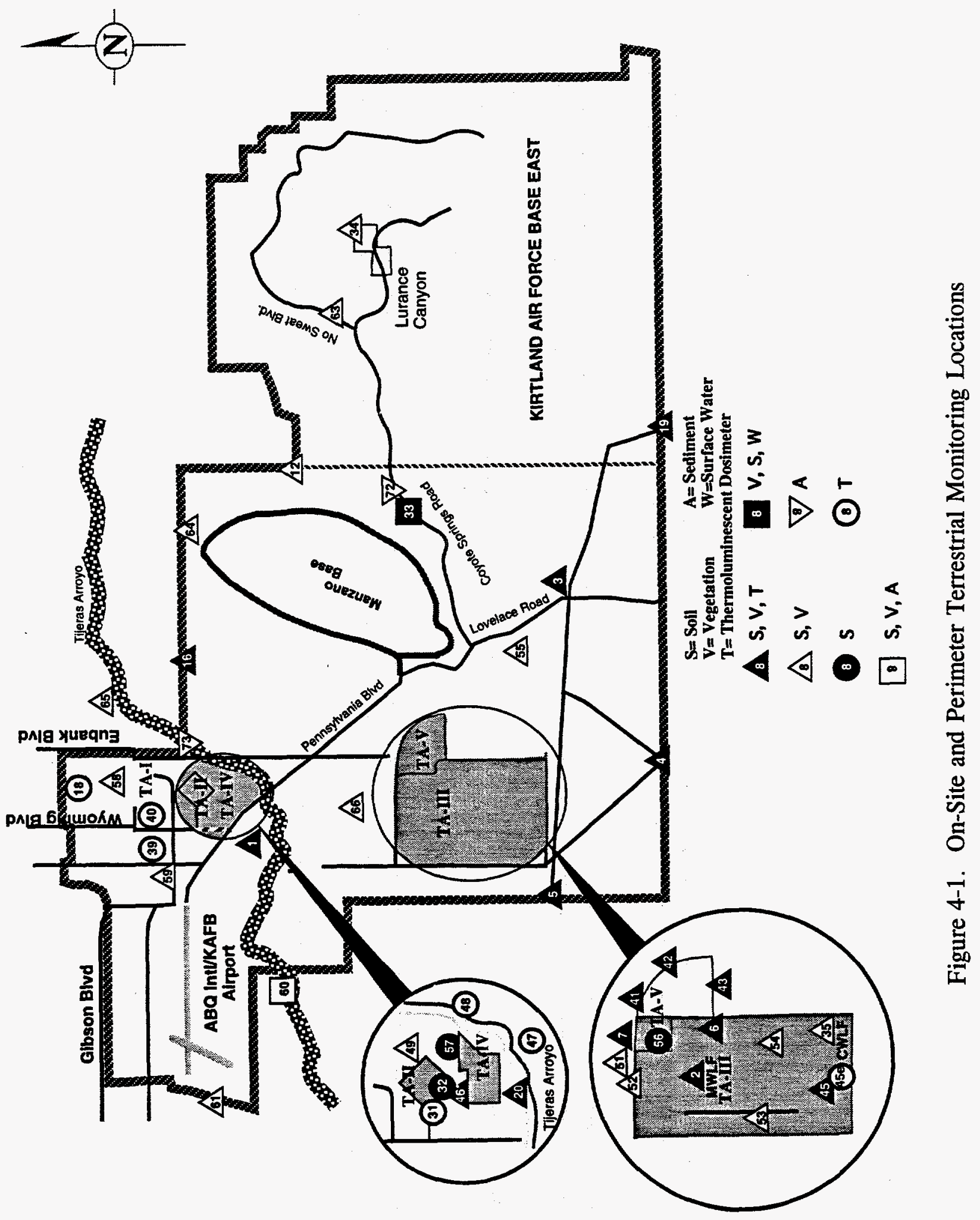




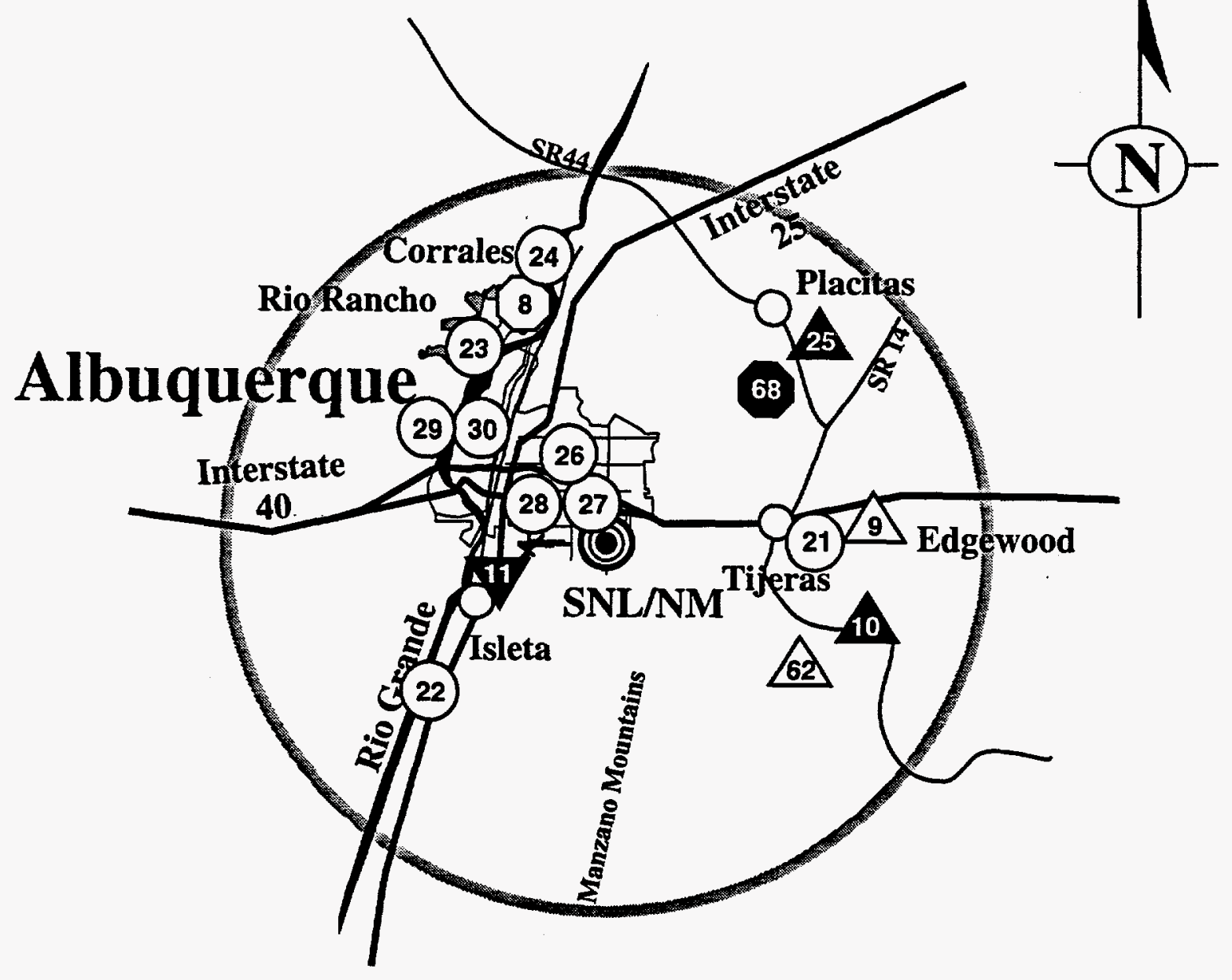

$\begin{array}{lc}\text { S= Soil } & \text { A= Sediment } \\ \text { V= Vegetation } & \text { W=Surface Water } \\ T=\text { Thermoluminescent Dosimeter }\end{array}$
$8 \mathrm{~S}, \mathrm{~V}, \mathrm{~T}$
(8) $V, S, W, A$
S $S, V$
8 A,W
(8) $\mathrm{T}$
$8 \mathrm{~V}, \mathrm{~S}, \mathrm{~W}, \mathrm{AT}$

Figure 4-2. Off-Site Terrestrial Monitoring Locations 
Table 4-1. SNL/NM Terrestrial Surveillance Locations and Sample Types

\begin{tabular}{|c|c|c|c|c|}
\hline $\begin{array}{l}\text { Location } \\
\text { Number }\end{array}$ & & $\begin{array}{l}\text { Sampling } \\
\text { Location }\end{array}$ & $\begin{array}{l}\text { Location } \\
\text { Type }^{*}\end{array}$ & $\begin{array}{l}\text { Sample } \\
\text { Type }^{\dagger}\end{array}$ \\
\hline 1 & \multicolumn{2}{|c|}{ Pennsylvania Avenue } & $S$ & $\mathrm{~V}, \mathrm{~S}, \mathrm{~T}$ \\
\hline $2 \mathrm{NW}$ & \multicolumn{2}{|c|}{ Mixed Waste Landfill } & $\mathrm{S}$ & $\mathrm{V}, \mathrm{S}, \mathrm{T}$ \\
\hline $2 \mathrm{NE}^{\ddagger}$ & \multicolumn{2}{|c|}{ Mixed Waste Landfill } & $\mathrm{S}$ & $\mathrm{V}, \mathrm{S}$ \\
\hline $2 \mathrm{SE}$ & \multicolumn{2}{|c|}{ Mixed Waste Landfill } & $\mathrm{s}$ & $\mathrm{V}, \mathrm{S}$ \\
\hline $2 \mathrm{SW}$ & \multicolumn{2}{|c|}{ Mixed Waste Landfill } & $\mathrm{S}$ & V,S \\
\hline 3 & \multicolumn{2}{|c|}{ Coyote Canyon Control } & $\mathrm{S}$ & $\mathrm{V}, \mathrm{S}, \mathrm{T}$ \\
\hline 4 & \multicolumn{2}{|c|}{ Isleta Reservation Gate } & $\mathbf{P}$ & $\mathrm{V}, \mathrm{S}, \mathrm{T}$ \\
\hline 5 & \multicolumn{2}{|c|}{ McCormick Gate } & $\mathbf{P}$ & $\mathrm{V}, \mathrm{S}, \mathrm{T}$ \\
\hline 6 & \multicolumn{2}{|c|}{ Technical Area III, East of Water Tower } & $\mathbf{S}$ & $\mathrm{V}, \mathrm{S}, \mathrm{T}$ \\
\hline $7^{\ddagger}$ & \multicolumn{2}{|c|}{ North of Technical Area V, Arroyo } & s & $\mathrm{V}, \mathrm{S}, \mathrm{T}$ \\
\hline 8 & \multicolumn{2}{|c|}{ Corrales Bridge (upgradient of Rio Grande) } & $\mathrm{C}$ & $\mathrm{V}, \mathrm{S}, \mathrm{W}, \mathrm{A}$ \\
\hline 9 & \multicolumn{2}{|c|}{ Sedillo Hill, I-40, East of Albuquerque } & $\mathrm{C}$ & $\mathrm{V}, \mathrm{S}$ \\
\hline 10 & \multicolumn{2}{|c|}{ Oak Flats } & $\mathrm{C}$ & $\mathrm{V}, \mathrm{S}, \mathrm{T}$ \\
\hline $11^{\ddagger}$ & \multicolumn{2}{|c|}{ Isleta Pueblo, Rio Grande (downgradient) } & $\mathrm{C}$ & V,S,T,W,A \\
\hline 12 & \multicolumn{2}{|c|}{ NE Perimeter } & $\mathbf{P}$ & $\mathrm{V}, \mathrm{S}$ \\
\hline 16 & \multicolumn{2}{|c|}{ Four Hills } & $\mathrm{p}$ & V,S,T \\
\hline 18 & \multicolumn{2}{|c|}{ North Perimeter Road } & $\mathbf{P}$ & $\mathrm{T}$ \\
\hline 19 & \multicolumn{2}{|c|}{ Seismic Center Gate } & $\mathbf{P}$ & $\mathrm{V}, \mathrm{S}, \mathrm{T}$ \\
\hline 20 & \multicolumn{2}{|c|}{ Technical Area IV, SW } & $S$ & $\mathrm{~V}, \mathrm{~S}, \mathrm{~T}$ \\
\hline 21 & \multicolumn{2}{|c|}{ Bernalillo Fire Station 10, Tijeras } & $\mathrm{C}$ & $\mathrm{T}$ \\
\hline 22 & \multicolumn{2}{|c|}{ Los Lunas Fire Station } & $\mathrm{C}$ & $\mathrm{T}$ \\
\hline 23 & \multicolumn{2}{|c|}{ Rio Rancho Fire Station, 19th Avenue } & $\mathrm{C}$ & $\mathrm{T}$ \\
\hline 24 & \multicolumn{2}{|c|}{ Corrales Fire Station } & $\mathrm{C}$ & $\mathbf{T}$ \\
\hline 25 & \multicolumn{2}{|c|}{ Placitas Fire Station } & $\mathrm{C}$ & $\mathrm{V}, \mathrm{S}, \mathrm{T}$ \\
\hline 26 & \multicolumn{2}{|c|}{ Albuquerque Fire Station 9, Menaul NE } & $\mathrm{C}$ & $\mathbf{T}$ \\
\hline 27 & \multicolumn{2}{|c|}{ Albuquerque Fire Station 11, Southern SE } & $\mathrm{C}$ & $\mathbf{T}$ \\
\hline 28 & \multicolumn{2}{|c|}{ Albuquerque Fire Station 2, High SE } & $\mathrm{C}$ & $\mathrm{T}$ \\
\hline 29 & \multicolumn{2}{|c|}{ Albuquerque Fire Station 7,47 th NW } & $\mathrm{C}$ & $\mathrm{T}$ \\
\hline \multicolumn{5}{|c|}{$\begin{array}{l}\text { Note: } \mathrm{NW}=\text { northwest; } \mathrm{NE}=\text { northeast; } \mathrm{SE}=\text { southeast; } \mathrm{SW}=\text { southwest. } \\
\text { "Location types: } \mathrm{S}=\text { on-site } \mathrm{SNL} / \mathrm{NM} ; \mathrm{P}=\text { perimeter of } \mathrm{SNL} / \mathrm{NM} \text {; and } \mathrm{C}=\text { community (off-site). } \\
\text { 'Sample types: } \mathrm{V}=\text { vegetation, } \mathrm{S}=\text { soil, } \mathrm{W}=\text { surface water, } \mathrm{A}=\text { sediment, and } \mathrm{T}=\mathrm{TLD} \text { (thermoluminescent } \\
\text { dosimeter). }\end{array}$} \\
\hline \multicolumn{2}{|c|}{ 'Replicate sampling sites } & $\left\{\begin{array}{l}\mathrm{S} \text { and } \mathrm{V}: 2 \mathrm{NE}, 7,11 \text {, and } 53 . \\
\mathrm{W}: 11 . \\
\mathrm{A}: 11 \text { and } 73 .\end{array}\right.$ & & \\
\hline
\end{tabular}


Table 4-1 SNL/NM Terrestrial Surveillance Locations and Sample Types (Continued)

Location

Number
Sampling

Location

\section{Location \\ Type $^{*}$}

Sample

Type $^{\dagger}$

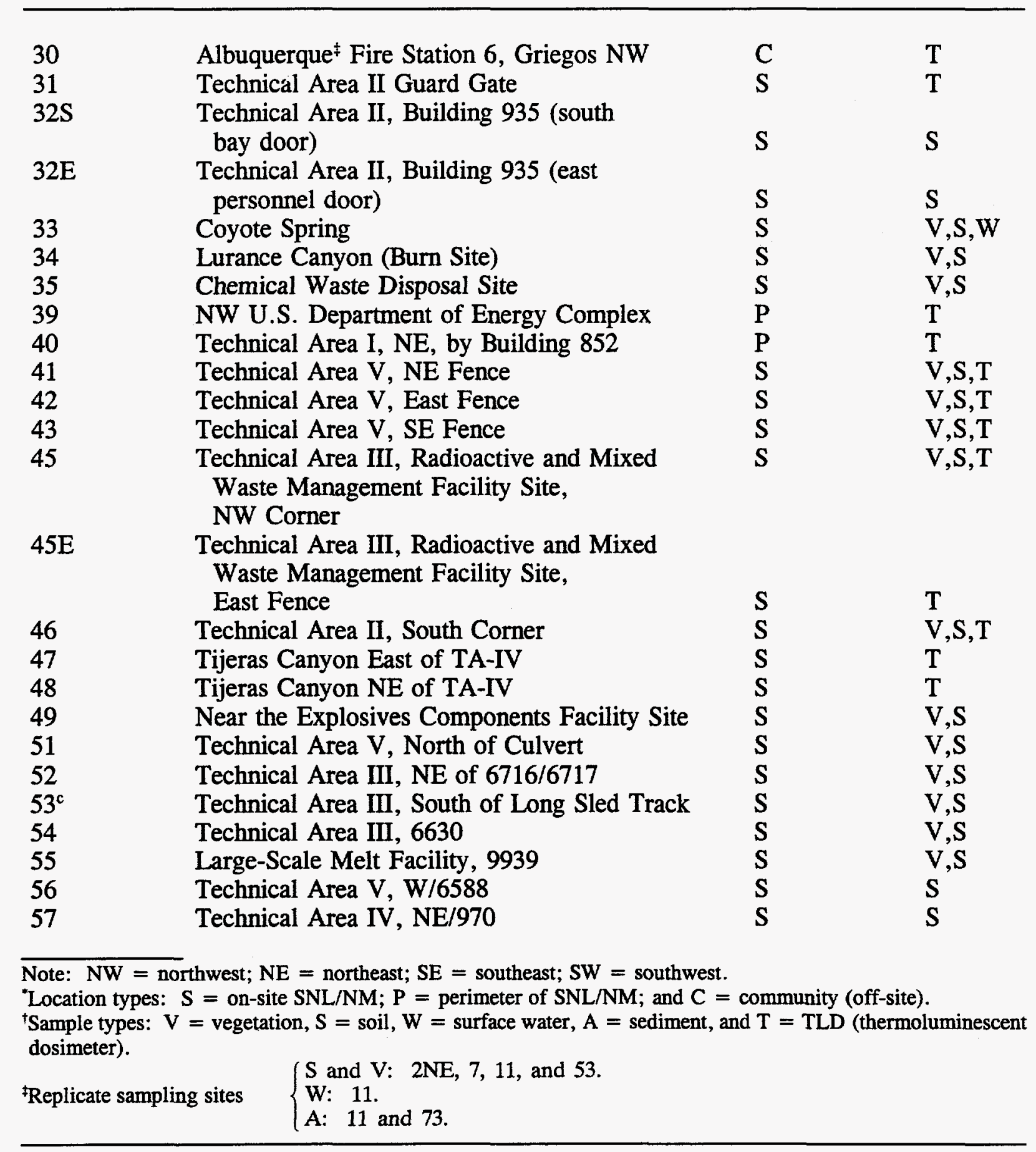


Table 4-1. SNL/NM Terrestrial Surveillance Locations and Sample Types (Concluded)

\begin{tabular}{llll}
$\begin{array}{l}\text { Location } \\
\text { Number }\end{array}$ & \multicolumn{1}{c}{$\begin{array}{c}\text { Sampling } \\
\text { Location }\end{array}$} & $\begin{array}{c}\text { Location } \\
\text { Type }^{*}\end{array}$ & $\begin{array}{c}\text { Sample } \\
\text { Type }^{\dagger}\end{array}$ \\
\hline 58 & North Base Housing & P & V,S \\
59 & Zia Park/SE & P & V,S \\
60 & Tijeras Arroyo (downgradient) & P & V,S,A \\
61 & Albuquerque International Sunport (west end) & P & V,S \\
62 & East Resident & C & V,S \\
63 & No Sweat Boulevard & P & V,S \\
64 & North Manzano & P & V,S \\
65 & Sandia Research Park & P & V,S \\
66 & Kirtland Underground Munitions Storage & S & V,S \\
& Complex & C & W,A \\
68 & Las Huertas & S & A \\
72 & Coyote Arroyo & P & A \\
$73^{\ddagger}$ & Tijeras Arroyo (upgradient) & & \\
\hline
\end{tabular}

Note: $\mathrm{NW}=$ northwest $\mathrm{NE}=$ northeast; $\mathrm{SE}=$ southeast; $\mathrm{SW}=$ southwest.

'Location types: $S=$ on-site SNL/NM; P = perimeter of SNL/NM; and C = community (off-site).

'Sample types: $\mathrm{V}=$ vegetation, $\mathrm{S}=$ soil, $\mathrm{W}=$ surface water, $\mathrm{A}=$ sediment, and $\mathrm{T}=\mathrm{TLD}$ (thermoluminescent dosimeter).

${ }^{\mathrm{t}}$ Replicate sampling sites $\quad\left\{\begin{array}{l}\mathrm{S} \text { and } \mathrm{V}: 2 \mathrm{NE}, 7,11 \text {, and } 53 . \\ \mathrm{W}: 11 . \\ \mathrm{A}: 11 \text { and } 73 .\end{array}\right.$

suspended solids ( $>0.45$ micron $[\mu \mathrm{m}]$ ) were analyzed. Appendix D describes sample collection and analytical procedures. Appendix $\mathrm{E}$ lists minimum detection limits for each type of radionuclide analysis.

Soil, sediment, and vegetation samples were analyzed for tritium (H-3) and by gamma spectroscopy analysis; soil and sediment were also analyzed for total uranium $\left(\mathrm{U}_{\mathrm{to}}\right)$. Gross alpha, beta, and gamma spectroscopy analyses, and uranium (U) and H-3 analyses, were performed on surface-water samples. Soil and sediment samples were analyzed for 20 elements by the inductively coupled plasma (ICP) method.

\subsection{TERRESTRIAL RADIOLOGICAL SURVEILLANCE RESULTS}

To meet the sampling objective of the terrestrial surveillance program, data were analyzed using the following strategy. For vegetation and soil data, each individual perimeter and 
SNL/NM sampling location was compared to the mean of the off-site data to identify locations with concentrations higher than the background levels (off-site). If the concentration at a location exceeds two standard deviations of the mean of the off-site data in May and August, the location is further investigated by examining the data trend in past years. Trend analysis was performed using data collected in the past four years, during which time the same analytical laboratory was used. For surface water taken from the Rio Grande and sediments taken from Tijeras Arroyo, upgradient and downgradient data were compared to determine SNL/NM's contributions. The following subsections present the conclusions and major findings of these analyses; analyses details are described in 1994 Environmental Surveillance Data Analysis (Shyr and Skipper 1995). The data for all individual sample locations are reported in Data from Terrestrial Surveillance in CY94 (Shyr and McClellan 1995).

\subsubsection{Vegetation}

Tables 4-2 and 4-3 present the summary statistics for $\mathrm{H}-3$ concentrations in vegetation samples taken in May and August of 1994, respectively. H-3 concentrations at SNL/NM locations are skewed toward small values as indicated by the small median compared to the mean. The large mean for the perimeter location in May was due to the large value of 16 picocuries per gram ( $\mathrm{pCi} / \mathrm{g}$ ) at location 63 . The value of $16 \mathrm{pCi} / \mathrm{g}$ could be a measurement error because it was two to three orders of magnitude higher than the data collected at the same location in past years. If this value is excluded, the mean drops to -0.04 , which is close to the mean for offsite locations.

Table 4-2. Summary Statistics for Concentrations of Tritium in Vegetation, May 1994

\begin{tabular}{llcccccc} 
& & & \multicolumn{5}{c}{ Raw Data } \\
\cline { 7 - 8 } Radionuclide & $\begin{array}{c}\text { Location } \\
\text { Type }\end{array}$ & \begin{tabular}{c} 
Sample \\
\cline { 5 - 7 }
\end{tabular} & Size & Median & Mean & $\begin{array}{c}\text { Standard } \\
\text { Deviation }\end{array}$ & Range \\
\hline \multirow{2}{*}{ Tritium (pCi/mL) } & SNL/NM & 24 & 0.05 & 0.50 & 1.60 & -0.13 to 7.50 \\
& Perimeter & 12 & -0.05 & 1.30 & 4.63 & -0.16 to 16.00 \\
& & & $-0.06^{*}$ & $-0.04^{*}$ & $0.10^{*}$ & -0.16 to $0.10^{*}$ \\
& Off-Site & 6 & -0.02 & -0.02 & 0.03 & -0.07 to 0.02
\end{tabular}

"Perimeter summary statistics calculated without location 63 which had tritium equal to 16 picocuries per milliliter ( $\mathrm{pCi} / \mathrm{mL}$ ). 
Table 4-3. Summary Statistics for Concentrations of Tritium in Vegetation, August 1994

\begin{tabular}{|c|c|c|c|c|c|c|}
\hline \multirow[b]{2}{*}{ Radionuclide } & \multirow[b]{2}{*}{$\begin{array}{l}\text { Location } \\
\text { Type }\end{array}$} & \multirow[b]{2}{*}{$\begin{array}{c}\text { Sample } \\
\text { Size }\end{array}$} & \multicolumn{4}{|c|}{ Raw Data } \\
\hline & & & Median & Mean & $\begin{array}{l}\text { Standard } \\
\text { Deviation }\end{array}$ & Range \\
\hline \multirow[t]{3}{*}{ Tritium (pCi/mL) } & SNL/NM & 24 & 0.07 & 0.44 & 1.09 & -0.11 to 5.00 \\
\hline & Perimeter & 12 & 0.09 & 0.09 & 0.05 & 0.02 to 0.19 \\
\hline & Off-Site & 6 & 0.03 & 0.02 & 0.05 & -0.03 to 0.09 \\
\hline
\end{tabular}

Note: $\mathrm{pCi} / \mathrm{mL}=$ picocuries per milliliter.

Perimeter locations 58 and 65 showed elevated H-3 concentrations in May and August when compared to the mean of the off-site data (Shyr and Skipper 1995); however, no trend (increasing or decreasing) was detected in the past four years. SNL/NM locations $2 \mathrm{NE}, 2 \mathrm{NW}$, 2SE, 2SW, 35, and 45 had elevated H-3 concentrations when compared to the off-site locations. These SNL/NM locations are associated with identified ER Project sites in controlled areas. Based on the data collected during the past four years, no trend was detected (Shyr and Skipper 1995).

\subsubsection{Soil}

Table 4-4 presents the summary statistics for $\mathrm{U}_{\text {tot }}$, cesium (Cs-137), and $\mathrm{H}-3$ concentrations in soil samples taken in May and August of 1994. Concentrations of H-3 at SNL/NM locations are still skewed toward small values as indicated by the small median compared to the mean. The value of 1800 picocuries per milliliter $(\mathrm{pCi} / \mathrm{mL})$ for the soil sample taken from location 32E has an impact on the statistics for SNL/NM locations as indicated by the adjusted statistics by excluding the value. Location $32 \mathrm{E}$ is within a controlled area and has shown an elevated $\mathrm{H}-3$ concentration in past years. Specific investigations are underway and the results will be made available to the public in a later report.

Perimeter locations 12 and 64 showed elevated Cs-137 concentrations in May and August when compared to the mean of the off-site locations (Shyr and Skipper 1995); however, there was no trend (increasing or decreasing) detected in the past four years. SNL/NM locations 2NE, $2 \mathrm{NW}, 2 \mathrm{SE}, 2 \mathrm{SW}, 32 \mathrm{E}, 32 \mathrm{~S}$, and 53 had elevated $\mathrm{H}-3$ concentrations when compared to off-site locations. These SNL/NM locations are associated with identified ER sites in controlled areas. Although H-3 concentrations are elevated at these locations, no trend was detected based on the data from the past four years (Shyr and Skipper 1995). 
Table 4-4. Summary Statistics for Concentrations of Soil Radionuclides, May and August 1994

\begin{tabular}{|c|c|c|c|c|c|c|}
\hline \multirow[b]{2}{*}{ Radionuclide } & \multirow[b]{2}{*}{$\begin{array}{l}\text { Location } \\
\text { Type }\end{array}$} & \multirow[b]{2}{*}{$\begin{array}{c}\text { Sample } \\
\text { Size }\end{array}$} & \multicolumn{4}{|c|}{ Raw Data } \\
\hline & & & Median & Mean & $\begin{array}{c}\text { Standar } \\
\text { Deviatio }\end{array}$ & Range \\
\hline \multicolumn{7}{|l|}{$\underline{\text { May }}$} \\
\hline Uranium, total $(\mu \mathrm{g} / \mathrm{g})$ & $\begin{array}{l}\text { SNL } \\
\text { Perimeter } \\
\text { Off-Site }\end{array}$ & $\begin{array}{c}28 \\
12 \\
6\end{array}$ & $\begin{array}{l}1.10 \\
1.40 \\
1.80\end{array}$ & $\begin{array}{l}1.25 \\
1.35 \\
1.98\end{array}$ & $\begin{array}{l}0.31 \\
0.33 \\
0.69\end{array}$ & $\begin{array}{l}0.80 \text { to } 1.80 \\
0.80 \text { to } 1.80 \\
1.20 \text { to } 3.00\end{array}$ \\
\hline Cesium-137 (pCi/g) & $\begin{array}{l}\text { SNL } \\
\text { Perimeter } \\
\text { Off-Site }\end{array}$ & $\begin{array}{c}28 \\
12 \\
6\end{array}$ & $\begin{array}{l}0.18 \\
0.30 \\
0.20\end{array}$ & $\begin{array}{l}0.29 \\
0.45 \\
0.25\end{array}$ & $\begin{array}{l}0.27 \\
0.48 \\
0.21\end{array}$ & $\begin{array}{r}0.00 \text { to } 1.00 \\
-0.02 \text { to } 1.50 \\
0.02 \text { to } 0.58\end{array}$ \\
\hline Tritium (pCi/mL) & $\begin{array}{l}\text { SNL } \\
\text { Perimeter } \\
\text { Off-Site }\end{array}$ & $\begin{array}{c}28 \\
12 \\
6\end{array}$ & $\begin{array}{l}0.17 \\
0.13 \\
0.08\end{array}$ & $\begin{array}{l}7.67 \\
0.14 \\
0.11\end{array}$ & $\begin{array}{r}27.03 \\
0.11 \\
0.15\end{array}$ & $\begin{array}{c}-0.05 \text { to } 140.00 \\
0.01 \text { to } 0.32 \\
-0.01 \text { to } 0.39\end{array}$ \\
\hline \multicolumn{7}{|l|}{ August } \\
\hline Uranium, total $(\mu \mathrm{g} / \mathrm{g})$ & $\begin{array}{l}\text { SNL } \\
\text { Perimeter } \\
\text { Off-Site }\end{array}$ & $\begin{array}{c}28 \\
12 \\
6\end{array}$ & $\begin{array}{l}2.10 \\
2.35 \\
1.60\end{array}$ & $\begin{array}{l}2.21 \\
2.29 \\
1.65\end{array}$ & $\begin{array}{l}0.60 \\
0.98 \\
0.23\end{array}$ & $\begin{array}{l}1.20 \text { to } 3.80 \\
0.93 \text { to } 4.80 \\
1.30 \text { to } 2.00\end{array}$ \\
\hline Cesium-137 (pCi/g) & $\begin{array}{l}\text { SNL } \\
\text { Perimeter } \\
\text { Off-Site }\end{array}$ & $\begin{array}{c}24 \\
9 \\
6\end{array}$ & $\begin{array}{l}0.18 \\
0.24 \\
0.25\end{array}$ & $\begin{array}{l}0.31 \\
0.56 \\
0.34\end{array}$ & $\begin{array}{l}0.38 \\
0.62 \\
0.34\end{array}$ & $\begin{array}{l}-0.03 \text { to } 1.80 \\
0.02 \text { to } 1.70 \\
0.05 \text { to } 0.96\end{array}$ \\
\hline Tritium (pCi/mL) & $\begin{array}{l}\text { SNL } \\
\text { Perimeter } \\
\text { Off-Site }\end{array}$ & $\begin{array}{c}28 \\
12 \\
6\end{array}$ & $\begin{array}{l}0.15 \\
0.14^{*} \\
0.08 \\
0.14\end{array}$ & $\begin{array}{c}69.89 \\
5.81^{*} \\
0.18 \\
0.13\end{array}$ & $\begin{array}{c}339.71 \\
21.26^{*} \\
0.20 \\
0.06\end{array}$ & $\begin{array}{c}-0.02 \text { to } 1,800.00 \\
-0.02 \text { to } 110.00^{*} \\
0.00 \text { to } 0.67 \\
0.05 \text { to } 0.19\end{array}$ \\
\hline
\end{tabular}

Note: $\mu \mathrm{g} / \mathrm{g}=$ micrograms per gram; $\mathrm{pCi} / \mathrm{g}=$ picocuries per gram; $\mathrm{pCi} / \mathrm{mL}=$ picocuries per milliliter.

*SNL/NM summary statistics calculated without location $32 \mathrm{E}$ which had tritium equal to $1,800 \mathrm{pCi} / \mathrm{mL}$. 
Locations showing an increasing trend in radionuclide soil concentrations included perimeter locations 58 and 64 in U concentration (Figure 4-3); SNL/NM locations 1, 20, 32S, 42, 43, 46, and 66 in U concentration (Figure 4-4); and SNL/NM location 6 in Cs-137 concentration (Figure 4-5). As indicated in Figures 4-3 and 4-4, the data taken in August 1994 may have some impact on the trend. If the values for August 1994 are excluded, the only statistically significant trends are for locations 20,42 , and 66 . The trend will be investigated further next year by including data beyond the past four years.

\subsubsection{Surface Water}

Tables 4-5 and 4-6 summarize the data for surface water taken from three off-site locations and one SNL/NM location in May and August of 1994. Location 8 is on the Rio Grande upgradient of SNL/NM and Albuquerque; location 11 is downgradient. The 1994 data, along with the past three years' data, were used to determine whether there was a statistically significant difference between upgradient and downgradient radionuclide concentrations. The results showed there was no statistically significant difference (Shyr and Skipper 1995). Because the radionuclide concentrations for the SNL/NM location seem higher than those from off-site locations, trend analysis was performed on the SNL/NM location based on the past four years' data; no trend was detected (Shyr and Skipper 1995).

\subsubsection{Sediment}

Table 4-7 summarizes the data for sediment samples taken from the Rio Grande, Las Huertas, and arroyos in May and August of 1994. Location 73 is in Tijeras Arroyo where it enters SNL/NM; location 60 is downgradient of SNL/NM. The 1994 data and the past three years' data were used to test whether there was any statistically significant difference between upgradient and downgradient radionuclide concentrations. The results showed no statistically significant difference between Tijeras Arroyo upgradient and downgradient locations for $\mathrm{H}-3$, U, and Cs-137 (Shyr and Skipper 1995). Location 8 is on the Rio Grande upgradient of SNL/NM and Albuquerque; location 11 is downgradient. No statistically significant difference was detected between locations 8 and 11 for $\mathrm{H}-3, \mathrm{U}$, and Cs-137 based on the past four years' data. Radionuclide concentrations in the sediments taken from location 72 showed no trend in the past four years.

\subsubsection{Environmental Thermoluminescent Dosimeters}

Table 4-8 summarizes the annual TLD dose equivalent estimates for the on-site, perimeter, and off-site locations (listed in Table 4-1). These estimates include natural background levels and facility contributions (if any). Because the mean, the standard deviation, and the range were similar for SNL/NM, perimeter, and off-site locations, individual sites were not compared to the mean of the off-site locations as in the approach used for the soil and sediment samples. Instead, the means of three location groups were compared to detect any differences using a one-way analysis of variance (Shyr and Skipper 1995). No statistically significant difference was detected among SNL/NM, perimeter, and off-site locations. 


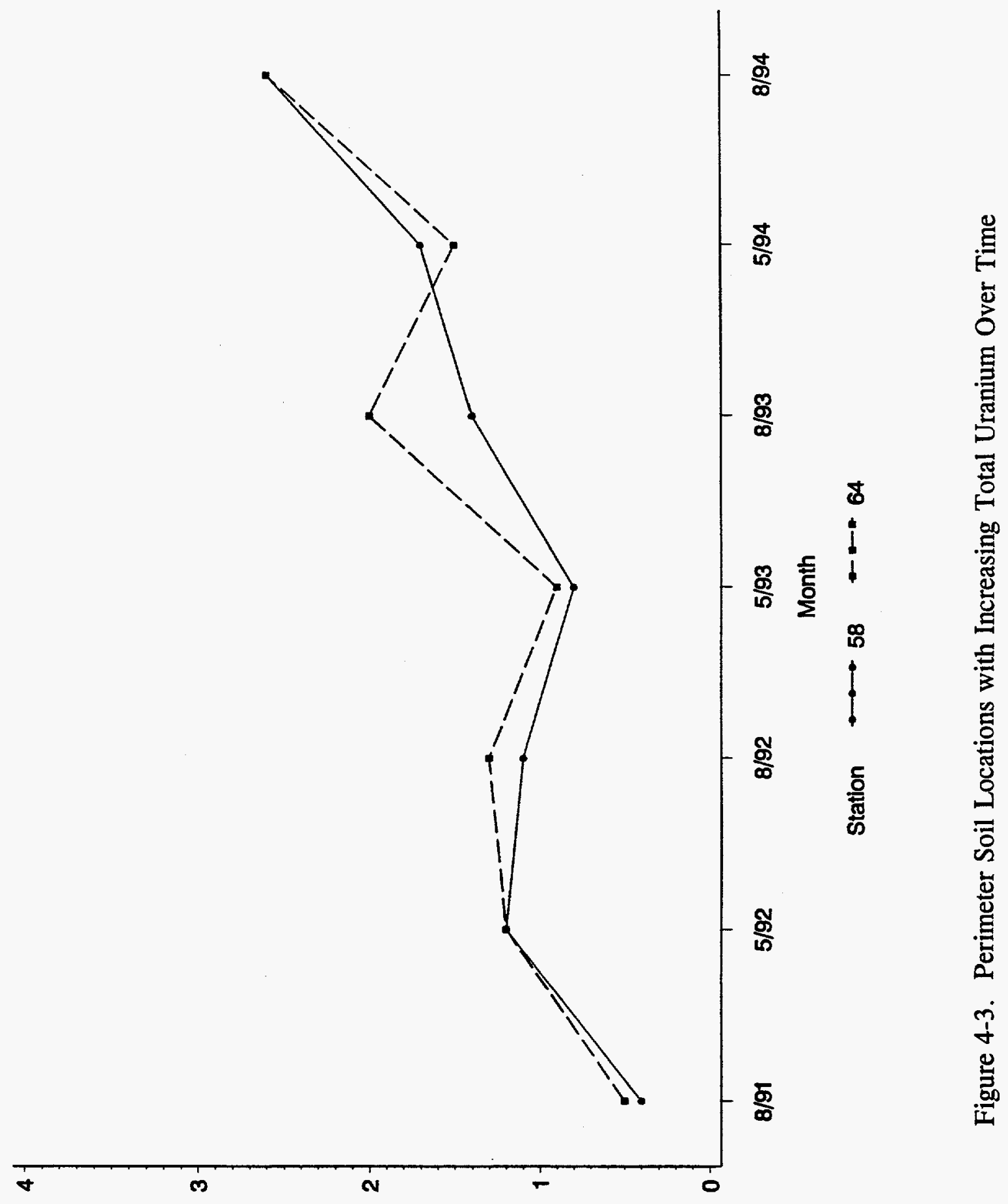

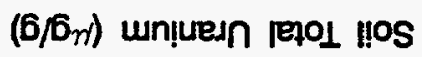




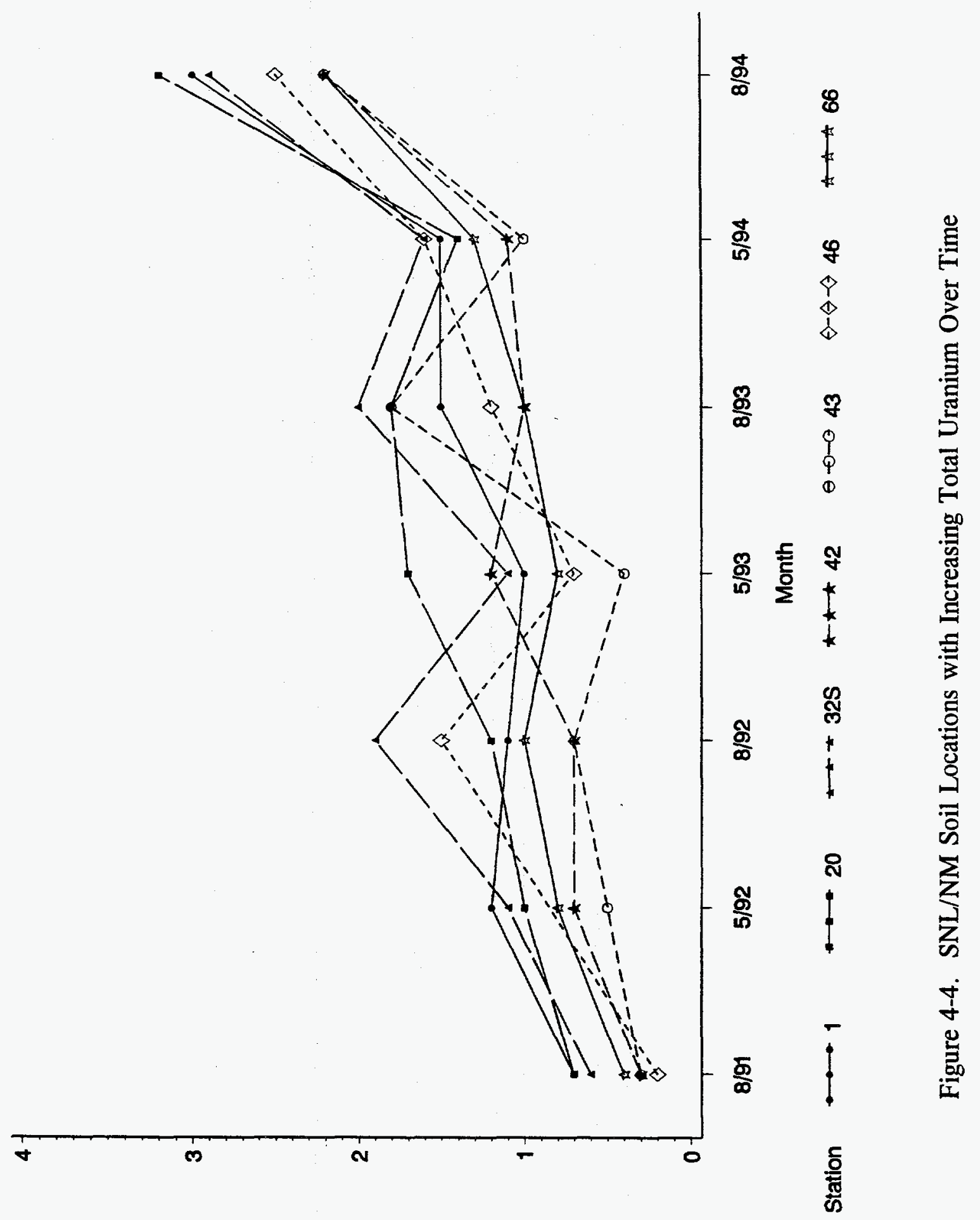

$(6 / 6 n)$ wn!uredn rełol 


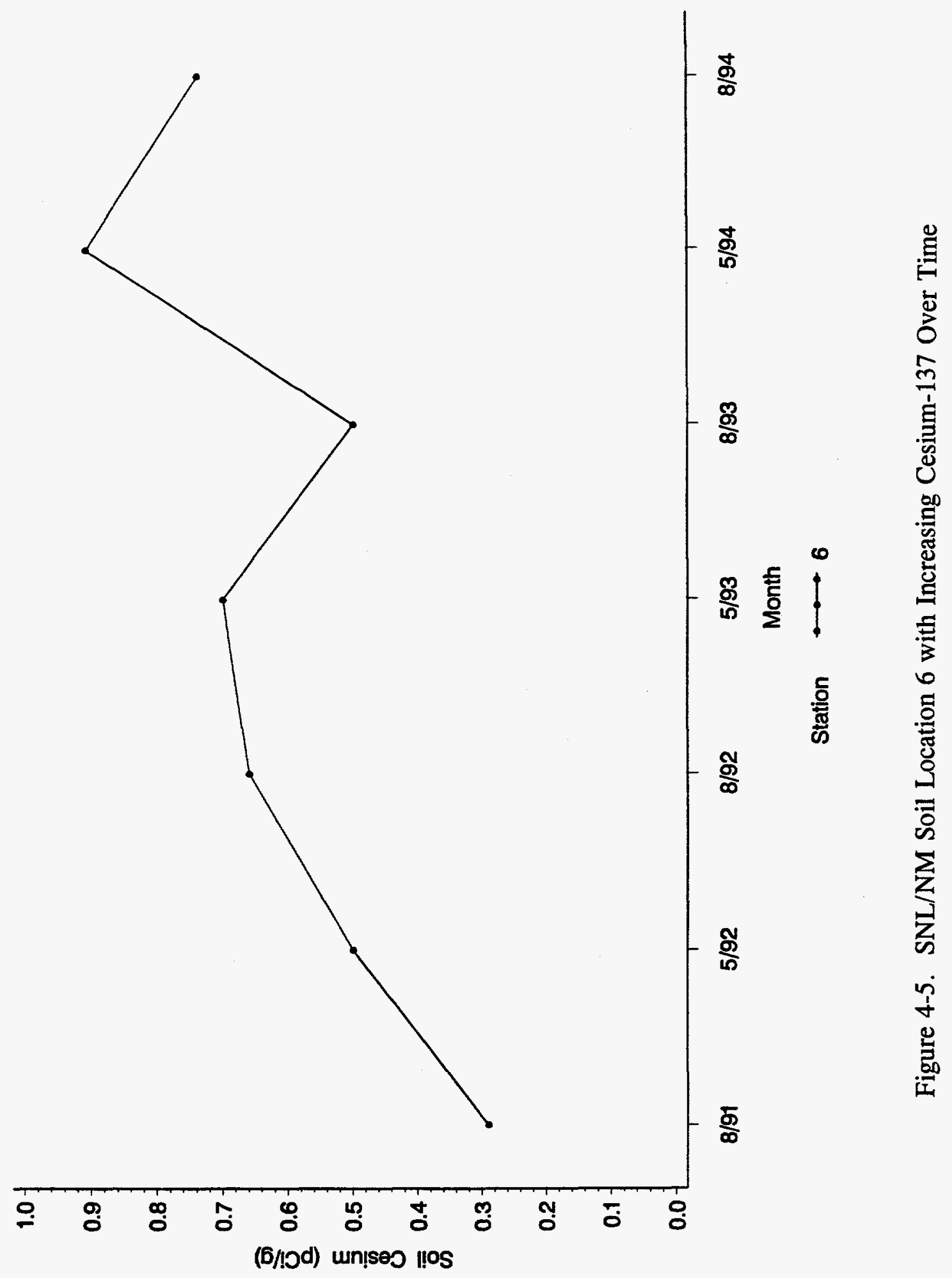


Table 4-5. Concentrations of Surface-Water Radionuclides, May 1994

Analysis

(units)

Location Type (number)

Total Filtered

Suspended

Water Water Solids

Gross Alpha
$(\mathrm{pCi} / \mathrm{L})$

Gross Beta

$(\mathrm{pCi} / \mathrm{L})$

Uranium, total $(\mathrm{mg} / \mathrm{L})$ $(\mathrm{pCi} / \mathrm{mL})$
River upgradient (8)

River downgradient (11)

On-site (33)

Stream (68)

River upgradient (8)

River downgradient (11)

On-site (33)

Stream (68)

River upgradient (8)

River downgradient (11)

On-site (33)

Stream (68)

River upgradient (8)

River downgradient (11)

On-site (33)

Stream (68)

$\begin{array}{rr}2 & \\ 8 & \\ 12 & 13 \\ 1 & \end{array}$

\section{1}

2

13

$-0.67$

2

$-0.33$

$-0.67$

$\begin{array}{rrc}5 & 4 & 2 \\ 13 & 3 & 3.67 \\ 32 & 15 & -0.67 \\ 4 & 3 & 0\end{array}$

$1.9 \times 10^{-3} 1.6 \times 10^{-3}$

$2 \times 10^{-6}$

$2.3 \times 10^{-3} \quad 1.6 \times 10^{-3}$

$3.3 \times 10^{-6}$

$6.8 \times 10^{-3} 5.4 \times 10^{-3}$

$3.3 \times 10^{-6}$

$1.2 \times 10^{-3} 1.3 \times 10^{-3}$

$2.6 \times 10^{-6}$

$\begin{array}{lll}0.09 & -0.02 & \text { NA } \\ 0.04 & 0.10 & \text { NA } \\ 0.06 & 0.02 & \text { NA } \\ 0.22 & 0.20 & \text { NA }\end{array}$

$\overline{\text { Note: }} \mathrm{pC} i / \mathrm{L}=$ picocuries per liter; $\mathrm{mg} / \mathrm{L}=$ milligrams per liter; $\mathrm{pCi} / \mathrm{mL}=$ picocuries per milliliter; NA = filters were not analyzed for tritium.

In addition to the analysis of the 1994 data, TLD data from the past 12 years were analyzed to detect any trend (Shyr and Skipper 1995). TLD measurements from SNL/NM, perimeter, and off-site locations were consistent over the past 12 years, although SNL/NM sites were approximately 10 percent higher than perimeter and off-site locations during the period from 1986 through 1989 (Figure 4-6). No trend was detected in any group over the past 12 years.

During March and April 1993, Edgerton, Germeshausen \& Grier Corporation (EG\&G) Energy Measurements Group performed an aerial radiological survey of SNL/NM and the surrounding area. The survey measured the terrestrial gamma radiation to determine the levels of natural and man-made radiation. The helicopter used in this survey was outfitted with two detector pods and flown at approximately 150 feet (ft) above the survey area. 
Table 4-6. Concentrations of Surface-Water Radionuclides, August 1994

\begin{tabular}{llccc}
$\begin{array}{l}\text { Analysis } \\
\text { (units) }\end{array}$ & Location Type (number) & $\begin{array}{c}\text { Total } \\
\text { Water }\end{array}$ & $\begin{array}{c}\text { Filtered } \\
\text { Water }\end{array}$ & $\begin{array}{c}\text { Suspended } \\
\text { Solids }\end{array}$ \\
\hline & & & & \\
Gross Alpha & River upgradient (8) & 15 & 4 & 32 \\
(pCi/L) & River downgradient (11) & 15 & 3 & 26.67 \\
& On-site (33) & 4 & 6 & -1.33 \\
& Stream (68) & 3 & 1 & 1.33 \\
Gross Beta & River upgradient (8) & 22 & 6 & 43.33 \\
(pCi/L) & River downgradient (11) & 22 & 7 & 40 \\
& On-site (33) & 16 & 37 & -1.33 \\
& Stream (68) & 3 & 3 & 2.67 \\
Uranium, total & River upgradient (8) & 0.0029 & 0.0028 & 0.004 \\
(mg/L) & River downgradient (11) & 0.0026 & 0.0026 & 0.0053 \\
& On-site (33) & 0.0065 & 0.0057 & 0.00013 \\
& Stream (68) & 0.0010 & 0.0011 & 0.00023 \\
Tritium & River upgradient (8) & 0.03 & 0.19 & NA \\
(pCi/mL) & River downgradient (11) & 0.26 & 0.02 & NA \\
& On-site (33) & 0.04 & 0.00 & NA \\
& Stream (68) & 0.02 & 0.02 & NA
\end{tabular}

Note: $\mathrm{pCi} / \mathrm{L}=$ picocuries per liter; $\mathrm{mg} / \mathrm{L}=$ milligrams per liter; $\mathrm{pCi} / \mathrm{mL}=$ picocuries per milliliter; NA = filters were not analyzed for tritium.

This survey showed that the level of natural gamma radiation was the same as that measured in 1981 using a similar technique (EG\&G 1994). The only two man-made sources at SNL/NM that showed an elevated gross count rate were the Mixed Waste Landfill (MWL) and the storage and salvage yard in TA-III. Isotope Cs-137 and cobalt-60 (Co-60) were identified at the MWL and the storage and salvage yard, respectively. Cs-137 was identified in the 1981 survey at the same location but not Co-60. Isotopes, besides Cs-137, that might have contributed to the higher gross count rate at the MWL could not be identifed because of their low gamma energies caused by attenuation to and scattering before reaching the detectors (EG\&G 1994). 
Table 4-7. Concentrations of Sediment Radionuclides, May and August 1994

\begin{tabular}{|c|c|c|c|c|}
\hline \multirow[b]{2}{*}{ Sediment Type } & \multirow[b]{2}{*}{ Location Type (number) } & \multicolumn{3}{|c|}{ Concentrations } \\
\hline & & $\begin{array}{l}\text { Total Uranium } \\
(\mu \mathrm{g} / \mathrm{g})\end{array}$ & $\begin{array}{c}\text { Tritium } \\
\text { (pCi/mL) }\end{array}$ & $\begin{array}{l}\text { Cesium-137 } \\
\text { (pCi/g) }\end{array}$ \\
\hline
\end{tabular}

$\underline{\text { May }}$

$\begin{array}{llrrr}\text { Arroyo } & \text { Upgradient (73) } & 1.7 & 0.12 & 0.05 \\ & \text { On-Site (72) } & 1.9 & 0.06 & -0.02 \\ & \text { Downgradient (60) } & 1.4 & 0.02 & 0.01 \\ & & & & \\ \text { River/ } & \text { Stream (68) } & 2.2 & -0.04 & 0.07 \\ \text { Stream } & \text { Upgradient (8) } & 1.8 & -0.06 & 0.01 \\ & \text { Downgradient (11) } & 2.5 & 0.03 & 0.27\end{array}$

$\underline{\text { August }}$

Arroyo

Upgradient (73)

1.4

0.18

0.00

On-Site (72)

1.7

$-0.01$

0.06

Downgradient (60)

1.1

0.15

$-0.02$

River/

Stream (68)

Upgradient (8)

2.0

0.13

0.10

Stream

Downgradient (11)

1.5

0.07

0.14

1.8

0.19

0.37

Note: $\mu \mathrm{g} / \mathrm{g}=$ micrograms per gram; $\mathrm{pCi} / \mathrm{mL}=$ picocuries per milliliter; $\mathrm{pCi} / \mathrm{g}=$ picocuries per gram.

\subsection{TERRESTRIAL NONRADIOLOGICAL SURVEILLANCE RESULTS}

Beginning in 1993, the terrestrial surveillance program scope was broadened to include sample analysis for total metals in soil. For the purpose of statistical analysis, the on-site samples were divided into three groups. Group 1 consists of samples from contiguous TA-I, TA-II, and TA-IV. Group 2 consists of samples from contiguous TA-III and TA-V. Group 3 consists of samples from the following outlying areas: Coyote Canyon Control, Coyote Spring, Lurance Canyon, Kirtland Underground Munitions Storage Complex (KUMSC), and Coyote Arroyo. The samples are analyzed for the following metals: aluminum, barium $(\mathrm{Ba})$, beryllium, cadmium (Cd), calcium (Ca), chromium $(\mathrm{Cr})$, cobalt $(\mathrm{Co})$, copper $(\mathrm{Cu})$, iron $(\mathrm{Fe})$, lead $(\mathrm{Pb})$, magnesium (Mg), manganese (Mn), nickel (Ni), potassium, strontium (Sr), titanium (Ti), 
Table 4-8. Summary of Thermoluminescent Dosimeter Measurements for 1994

\begin{tabular}{lcccc} 
& & \multicolumn{3}{c}{$\begin{array}{c}\text { Annual External Dose Equivalent } \\
\text { (mrem/yr) }\end{array}$} \\
\cline { 3 - 5 } Location & $\begin{array}{c}\text { Number of } \\
\text { Locations }\end{array}$ & Mean & $\begin{array}{c}\text { Standard } \\
\text { Deviation }\end{array}$ & Range \\
\hline SNL/NM (S) & 15 & 102.5 & 6.9 & 93.1 to 119.2 \\
Perimeter (P) & 7 & 101.0 & 9.5 & 92.0 to 117.3 \\
Community (C) & 12 & 99.6 & 9.1 & 87.4 to 117.4
\end{tabular}

Note: $\mathrm{mrem} / \mathrm{yr}=$ millirem per year.

vanadium (V), and zinc ( $\mathrm{Zn})$. Comparison of on-site, perimeter, and off-site samples will provide data to determine whether SNL/NM activities have contributed to the deposition of metals in the past. If SNL/NM activities do contribute to metal deposition, then a comparison of samples from the same sites over time will also provide data for monitoring SNL/NM's contribution to the increase in metals. Four sets of comparable samples have been obtained and analyzed thus far.

Beginning in 1994, samples of surface water taken in May and August from four locations were analyzed for metals. Location 8 is on the Rio Grande at the Corrales Bridge, north of Albuquerque. Location 11 is on the Rio Grande at Isleta Pueblo, south of Albuquerque. Comparison of monitoring results from these samples will provide data to determine whether metals are added to the river water as the Rio Grande flows past Albuquerque and SNL/NM. Location 68 is at Las Huertas, northeast of Albuquerque in the Sandia Mountains, and Location 33 is at Coyote Spring on SNL/NM. To distinguish between dissolved metals and metals in suspended material, the water was filtered. The filtered water, unfiltered water, and material on the filter were analyzed. The following subsections present summary statistics and findings. The data for all individual sample locations are reported in Data from Terrestrial Surveillance in CY94 (Shyr and McClellan 1995).

\subsubsection{Soil}

Table 4-9 summarizes the results of statistical comparisons of soil and sediment samples. Statistical comparisons of the sample means were done using a t-test of the sample means at the 95 percent confidence level (two-tailed, assuming unequal sample variances). Except for $\mathrm{Ti}$, the concentration means for most of the metals was not significantly higher for the on-site groups or perimeter samples than for the off-site samples. This was the case for both the May and August samples and corresponded to the 1993 results. The mean concentration of Ti was 


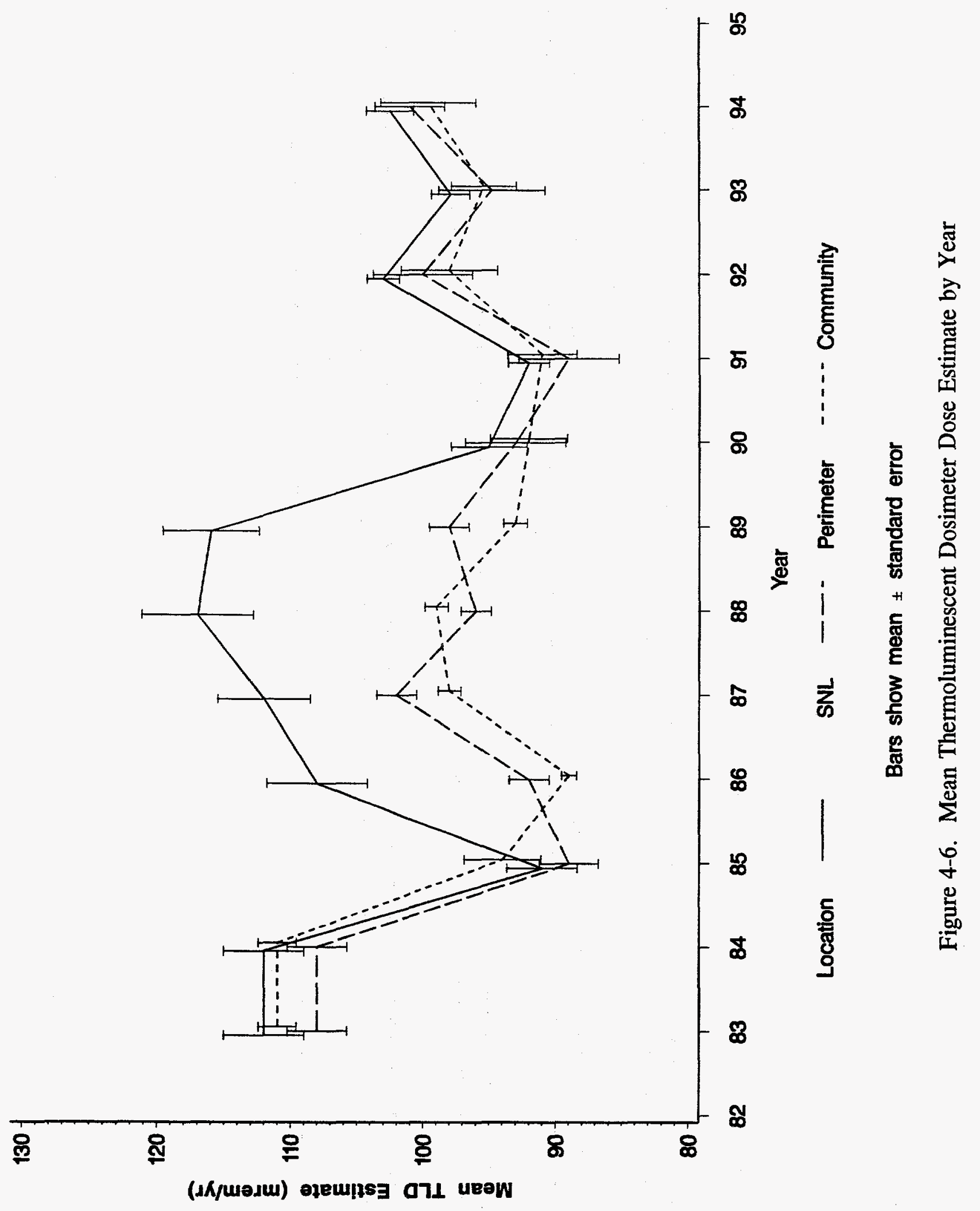


Table 4-9. Summary of Metal Concentrations in Soil and Sediment Samples

\begin{tabular}{|c|c|c|c|c|c|c|}
\hline \multirow[b]{2}{*}{ Metal } & \multirow[b]{2}{*}{ Month } & \multicolumn{5}{|c|}{ Metal Concentration Mean (ppm) } \\
\hline & & Group 1 & Group 2 & Group 3 & Perimeter & Off-Site \\
\hline \multirow[t]{2}{*}{ Aluminum } & May & 9,886 & 14,726 & 13,517 & 10,538 & 10,273 \\
\hline & August & 8,271 & 7,896 & 8,700 & 7,828 & 9,692 \\
\hline \multirow[t]{2}{*}{ Barium } & May & 110 & 85 & 129 & 118 & 221 \\
\hline & August & 113 & 82 & 101 & 105 & 184 \\
\hline \multirow[t]{2}{*}{ Beryllium } & May & 0.53 & 0.53 & 0.57 & 0.72 & 0.60 \\
\hline & August & 0.51 & 0.50 & 0.64 & 0.53 & 0.65 \\
\hline \multirow[t]{2}{*}{ Cadmium } & May & 0.54 & 0.50 & 0.50 & 0.51 & 0.70 \\
\hline & August & 0.89 & 0.61 & 0.56 & 0.52 & 0.58 \\
\hline \multirow{2}{*}{ Calcium } & May & 31,857 & 9,365 & 34,600 & 26,608 & 49,133 \\
\hline & August & 33,286 & 10,530 & 34,200 & 30,750 & 39,262 \\
\hline \multirow[t]{2}{*}{ Chromium } & May & 28.6 & 27.8 & 30.0 & 28.5 & 28.3 \\
\hline & August & 23.3 & 20.9 & 24.2 & 25.3 & 21.3 \\
\hline \multirow[t]{2}{*}{ Cobalt } & May & 4.83 & 3.32 & 5.13 & 4.98 & 4.92 \\
\hline & August & 5.04 & 3.32 & 4.66 & 4.79 & 5.64 \\
\hline \multirow[t]{2}{*}{ Copper } & May & 14.9 & 7.4 & 10.5 & 10.2 & 10.3 \\
\hline & August & 10.3 & 7.3 & 10.4 & 9.2 & 15.5 \\
\hline \multirow[t]{2}{*}{ Iron } & May & 14,571 & 10,396 & 14,333 & 13,500 & 12,033 \\
\hline & August & 11,929 & 8,383 & 10,060 & 9,483 & 11,254 \\
\hline \multirow[t]{2}{*}{ Lead } & May & 721 & 8.4 & 7.1 & 28.0 & 8.9 \\
\hline & August & 149 & 9.9 & 14.0 & 82.3 & 22.5 \\
\hline \multirow[t]{2}{*}{ Magnesium } & May & 3,543 & 2,570 & 3,850 & 3,962 & 3,787 \\
\hline & August & 3,429 & 2,239 & 3,480 & 3,428 & 3,808 \\
\hline \multirow[t]{2}{*}{ Manganese } & May & 226 & 165 & 275 & 257 & 337 \\
\hline & August & 219 & 154 & 254 & 244 & 325 \\
\hline
\end{tabular}


Table 4-9. Summary of Metal Concentrations in Soil and Sediment Samples (Concluded)

\begin{tabular}{|c|c|c|c|c|c|c|}
\hline \multirow[b]{2}{*}{ Metal } & \multirow[b]{2}{*}{ Month } & \multicolumn{5}{|c|}{ Metal Concentration Mean (ppm) } \\
\hline & & Group 1 & Group 2 & Group 3 & Perimeter & Off-Site \\
\hline \multirow[t]{2}{*}{ Nickel } & May & 8.14 & 6.91 & 11.00 & 8.54 & 9.87 \\
\hline & August & 8.43 & 7.04 & 10.80 & 7.78 & 10.62 \\
\hline \multirow[t]{2}{*}{ Potassium } & May & 2,343 & 2,430 & 3,233 & 2,454 & 2,213 \\
\hline & August & 2,206 & 1,909 & 2,210 & 1,983 & 2,046 \\
\hline \multirow[t]{2}{*}{ Silica } & May & 273 & 72 & 175 & 98 & 125 \\
\hline & August & 76 & 129 & 178 & 128 & 139 \\
\hline \multirow[t]{2}{*}{ Silver } & May & 0.571 & 0.504 & 0.517 & 0.531 & 0.513 \\
\hline & August & 0.500 & 0.500 & 0.500 & 0.506 & 0.500 \\
\hline \multirow[t]{2}{*}{ Strontium } & May & 56.1 & 26.3 & 63.0 & 57.2 & 94.1 \\
\hline & August & 62.7 & 25.4 & 62.8 & 55.6 & 85.6 \\
\hline \multirow[t]{2}{*}{ Titanium } & May & $804 *$ & $290 *$ & $530^{*}$ & $515^{*}$ & 185 \\
\hline & August & $466^{*}$ & $157^{*}$ & $244^{*}$ & $326^{*}$ & 114 \\
\hline \multirow[t]{2}{*}{ Vanadium } & May & 31.0 & 20.8 & 27.7 & 27.4 & 22.3 \\
\hline & August & 24.4 & 14.5 & 16.4 & 19.0 & 21.8 \\
\hline \multirow[t]{2}{*}{ Zinc } & May & 36.7 & 32.4 & 38.3 & 37.5 & 36.7 \\
\hline & August & 39.0 & 29.4 & 37.6 & 33.6 & 47.4 \\
\hline
\end{tabular}


significantly higher in the on-site and perimeter samples than in the off-site samples for both May and August. This was also the case in 1993. The relatively high concentration of Ti appears to be centered at Group 1 (TA-I, TA-II, and TA-IV) and diminishes as the distance from this area increases.

A salient feature of the data summary in Table 4-9 is the high mean concentration of $\mathrm{Pb}(721$ parts per million [ppm] and $149 \mathrm{ppm}$ for May and August, respectively) for Group 1. This high concentration of $\mathrm{Pb}$ is not statistically significant because the standard deviation for the Group 1 samples is large. The high $\mathrm{Pb}$ concentration comes from one sampling site, Site 20, which is in the vicinity of the KAFB skeet shooting range (in the direction of shotgun firing). The same result for $\mathrm{Pb}$ was obtained from the 1993 samples.

Samples from the three on-site groups and the perimeter have been consistently lower in $\mathrm{Ba}$ than the off-site samples. The higher $\mathrm{Ba}$ concentration in the off-site samples seems to be general, i.e., not attributable to one or two community sites. Samples from Groups 1 and 2 tend to be lower in Co than off-site samples. The difference is statistically significant for Group 2. Group 2 samples are also lower in $\mathrm{Cu}, \mathrm{Pb}, \mathrm{Mg}, \mathrm{Mn}, \mathrm{Ni}, \mathrm{Sr}$, and $\mathrm{Zn}$ as compared to off-site samples. In most cases, these differences are statistically significant. These results are also consistent with those obtained in 1993.

The overall results from the sampling program have been consistent for the four sampling periods. This consistency would tend to indicate that the sampling and analysis are not providing anomalous results and that any significant trends in deposition of metals by SNL/NM activities in the future would be detected. Deposition of metals by community activities near community sampling sites would also be detected. Over the past 2 years, no metals have shown a trend of changing concentration in any of the four sampling groups.

Table 4-10 shows the significant differences in metal concentrations between the off-site and the other four sampling groups, with all of the samples from the four sampling periods taken into account. The Ti concentration is higher in Groups 1 and 3 and the perimeter samples than in the off-site samples. The off-site samples are higher in $\mathrm{Ba}$ and $\mathrm{Mn}$ than samples from the other four groups. The off-site samples are high in $\mathrm{Cr}, \mathrm{Ni}$, and $\mathrm{Sr}$ relative to samples from other groups. Samples from Group 2 are low in $\mathrm{Ba}, \mathrm{Cr}, \mathrm{Co}, \mathrm{Cu}, \mathrm{Fe}, \mathrm{Pb}, \mathrm{Mg}, \mathrm{Mn}, \mathrm{Ni}, \mathrm{Sr}$, $\mathrm{V}$, and $\mathrm{Zn}$.

\subsubsection{Surface Water}

Comparison of analyses of water samples from Locations 8 and 11 does not indicate that metal concentrations increase significantly in river water as the Rio Grande flows through Albuquerque. For both sampling periods, there was a slight increase in sediment loading between locations 8 and 11 , but the ratios of the various metal concentrations remained constant, indicating no selective metal contamination. As expected, the spring water from SNL/NM Location 33 is lower in suspended material and higher in the dissolved hard water metals, $\mathrm{Ca}$ and $\mathrm{Mg}$, than river water. Metals which would be of concern, such as $\mathrm{Cr}$ and $\mathrm{Cd}$, are at or below quantifiable levels. 
Table 4-10. Metal Concentration Differences Between Off-Site and Other Sample Groups

\begin{tabular}{|c|c|c|c|c|c|}
\hline Metal & Group 1 & Group 2 & Group 3 & Perimeter & Off-Site \\
\hline Barium & $108-$ & 84- & $105-$ & $117-$ & 183 \\
\hline Chromium & 21.6- & $21.4-$ & & & 25.8 \\
\hline Cobalt & & $3.23-$ & & & 4.71 \\
\hline Copper & & $7.2-$ & & & 10.8 \\
\hline Iron & & 9,150 & & & 11,389 \\
\hline Lead & & 8.8- & & & 15.8 \\
\hline Magnesium & & $2,454-$ & & & \\
\hline Manganese & $221-$ & $154-$ & $252-$ & $252-$ & 306 \\
\hline Nickel & $7.86-$ & 7.09 & & $7.92-$ & 9.46 \\
\hline Strontium & $57-$ & $30-$ & & $53-$ & 80 \\
\hline Titanium & $589+$ & $15.9-$ & $364+$ & $436+$ & 201 \\
\hline Vanadium & & $32-$ & & & 22.3 \\
\hline Zinc & & & & & 43 \\
\hline $\begin{array}{ll}\text { Note: } & \text { - me } \\
& \text { grea }\end{array}$ & $\begin{array}{l}\text { ation is } \\
\text { site samp }\end{array}$ & than the & samples. & means the & tration is \\
\hline
\end{tabular}




\subsection{AIR QUALITY SURVEILLANCE AND EMISSIONS MONITORING}

\subsection{METEOROLOGICAL MONITORING PROGRAM}

The meteorological monitoring program at Sandia National Laboratories/New Mexico (SNL/NM) commenced operations on January 3, 1994. This program is integral to compliance with Title 40, Code of Federal Regulations, Part 61 (40 CFR 61), U.S. Department of Energy (DOE) Orders 5400.1 (DOE 1988a), 5400.5 (DOE 1990a), and 5500.3 (DOE 1991a), and DOE guidelines outlined in DOE/EH-0173T (DOE 1991b). The program will also generate data consistent with program guidelines for regulatory modeling applications. The meteorological monitoring program is one of the two programs that constitutes the Clean Air Network (CAN).

The main objective of the program is to provide data representative of the meteorology at SNL/NM. The program includes a nine-tower meteorological monitoring network which consists of six 10-meter (m) towers, two 60-m towers, and one 50-m tower. All towers are instrumented at the 3- and 10-m levels. Instrumentation has also been installed at the top of the taller towers. Figure 5-1 shows the tower locations and names.

The meteorological variables measured at all tower levels include wind speed and direction, the standard deviation of the horizontal wind speed (sigma theta), and temperature. Relative humidity is measured at all towers at the 3-m level. There are also two atmospheric pressure sensors and three rain gauges in the meteorological network: barometric pressure is measured at towers $\mathrm{A} 21$ and $\mathrm{A} 36$, and rain gauges are located at $\mathrm{SC1}, \mathrm{A} 36$, and $\mathrm{A} 21$ (Figure 5-1).

\subsubsection{Meteorological Monitoring Results}

Due to its central geographic position and the availability of data at all three of its instrument levels, the A36 60-m meteorological tower has been designated as the official tower to describe general meteorology at SNL/NM. The A15 tower, although closer to the most populous part of SNL/NM, shows microscale urbanization effects not seen at the rest of the meteorological tower sites.

Table 5-1 lists the annual summary developed with information from tower A36. Appendix A, Tables A-2 through A-8, presents climatic data from seven other CAN towers for comparison. Data from a ninth tower at the CWL was not included for 1994 due to reconfiguration of the tower area which resulted in its data being nonrepresentative.

In general, the annual statistics for each of the towers are similar; however, these statistics do not show the daily variability that is present across the network. A random comparison of six of nine towers for 2 months showed that the daily statistics could vary 2.8 meters per second $(\mathrm{m} / \mathrm{s})$ in average wind speed for the same day and up to $7.2 \mathrm{~m} / \mathrm{s}$ for the maximum wind recorded for the same day (for the same 2 months), and minimum or maximum temperatures could differ from 1.5 degrees Celsius $\left({ }^{\circ} \mathrm{C}\right)$ to $4.3^{\circ} \mathrm{C}$. Maximum wind speeds across SNL/NM can be extremely variable during the thunderstorm season. The maximum wind speed recorded 


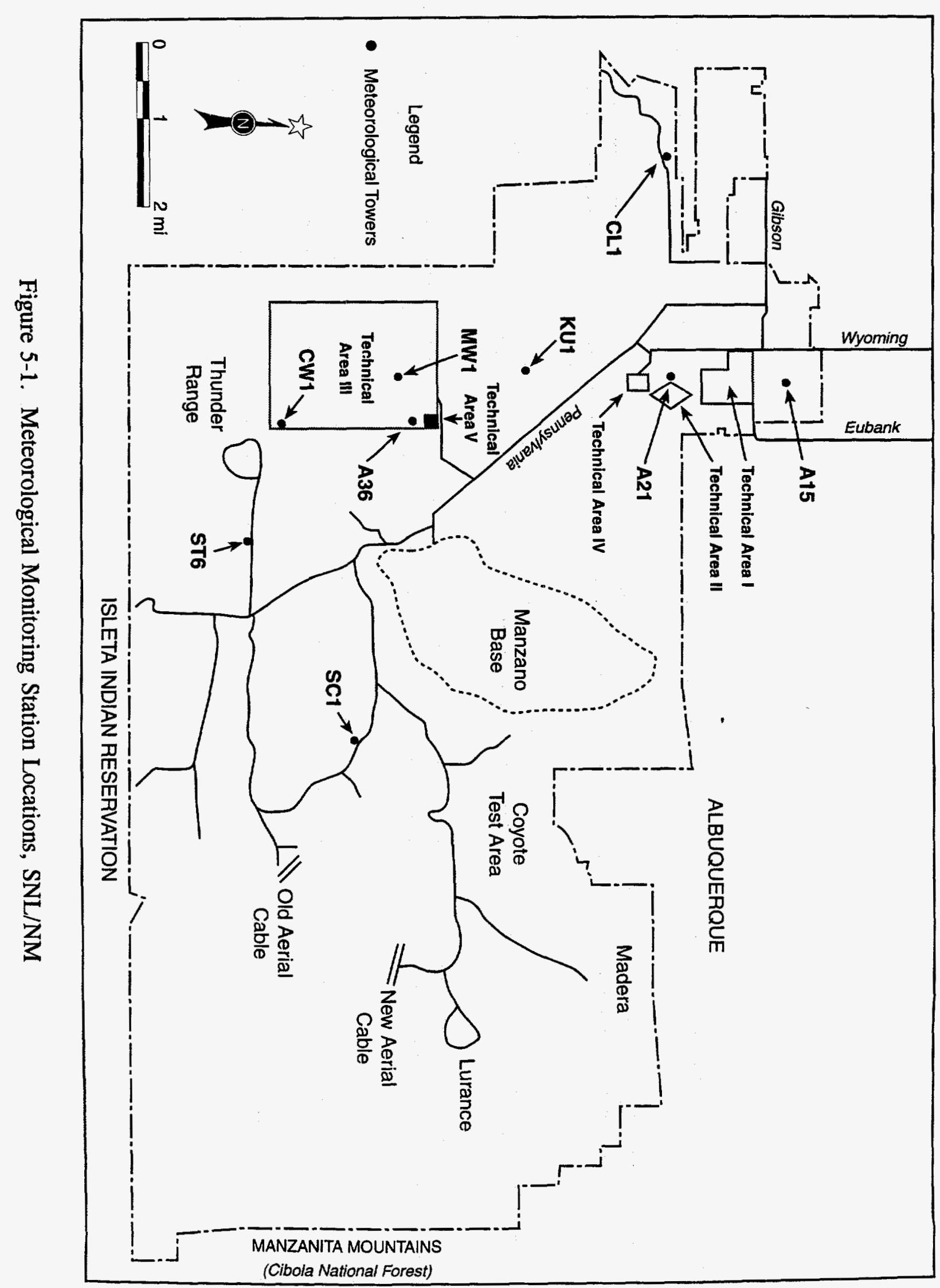


Table 5-1. Annual Summary Information from Tower A36

\begin{tabular}{|c|c|c|c|c|c|c|c|c|c|}
\hline Month* & $\begin{array}{c}\text { Average } \\
\text { Temperature } \\
\left({ }^{\circ} \mathrm{C}\right)\end{array}$ & $\begin{array}{c}\text { Maximum } \\
\text { Temperature } \\
\left({ }^{\circ} \mathrm{C}\right)\end{array}$ & $\begin{array}{c}\text { Minimum } \\
\text { Temperature } \\
\left({ }^{\circ} \mathrm{C}\right)\end{array}$ & $\begin{array}{c}\text { Average } \\
\text { RH } \\
(\%)\end{array}$ & $\begin{array}{l}\text { Average } \\
\text { Wind } \\
(\mathrm{m} / \mathrm{s})\end{array}$ & $\begin{array}{c}\text { Maximum } \\
\text { Wind } \\
(\mathrm{m} / \mathrm{s})\end{array}$ & $\begin{array}{l}\text { Average } \\
\text { Rain } \\
(\mathrm{cm})\end{array}$ & $\begin{array}{c}\text { Maximum } \\
24-\mathrm{hr} \\
(\mathrm{cm})\end{array}$ & $\begin{array}{l}\text { Pressure } \\
(\mathrm{mb})\end{array}$ \\
\hline January & 3.6 & 19.8 & -10.0 & 36.1 & 3.4 & 22.1 & 0.03 & 0.03 & 839.8 \\
\hline February & 4.6 & 19.3 & -11.2 & 40.2 & 3.4 & 22.1 & 0.66 & 0.51 & 836.7 \\
\hline March & 9.7 & 23.4 & -4.4 & 43.2 & 4.0 & 25.3 & 1.55 & 0.43 & 835.8 \\
\hline April & 13.5 & 27.8 & -2.6 & 31.5 & 4.2 & 21.3 & 0.15 & 0.13 & 833.0 \\
\hline May (99.9) & 18.6 & 33.1 & 7.2 & 37.4 & 4.4 & 25.3 & 7.21 & 1.65 & 832.6 \\
\hline June (98.3) & 26.1 & 39.3 & 13.6 & 24.4 & 3.6 & 22.9 & 1.12 & 0.97 & 832.1 \\
\hline July (97.4) & 25.7 & 36.6 & 15.6 & 32.7 & 4.1 & 26.9 & 2.46 & 0.94 & 833.4 \\
\hline August & 24.6 & 35.5 & 15.0 & 46.8 & 3.4 & 27.7 & 11.56 & 3.48 & 835.3 \\
\hline September & 20.6 & 30.5 & 8.4 & 46.0 & 3.1 & 18.1 & 3.43 & 1.32 & 836.7 \\
\hline October & 13.3 & 28.1 & 1.6 & 46.7 & 3.7 & 24.5 & 4.39 & 1.45 & 835.0 \\
\hline November & 6.7 & 21.3 & -7.6 & 51.2 & 3.6 & 19.7 & 3.78 & 1.88 & 836.8 \\
\hline December & 4.7 & 14.8 & -6.9 & 56.1 & 2.7 & 15.7 & 2.08 & 1.07 & 839.4 \\
\hline \multicolumn{10}{|l|}{ Annual } \\
\hline Averages & 14.3 & & & 41.0 & 3.6 & & 38.43 & & 835.5 \\
\hline \multicolumn{10}{|l|}{ Annual } \\
\hline Extremes & & 39.3 & -11.2 & & & 27.7 & & 3.48 & \\
\hline
\end{tabular}


during a severe thunderstorm was $50.9 \mathrm{~m} / \mathrm{s}$ at ST6 (Appendix A, Table A-4) while wind gusts between 22 and $27 \mathrm{~m} / \mathrm{s}$ were common throughout the rest of the network.

Temperature extremes for 1994 ranged from $-12.5^{\circ} \mathrm{C}$ to $39.7^{\circ} \mathrm{C}$ across the network. Precipitation was greater than the climatic normal for the area, ranging from 34.77 centimeters (cm) to $38.43 \mathrm{~cm}$. The maximum variability in rainfall between stations (when all three stations accumulated precipitation) occurred when a $1.65-\mathrm{cm}$ difference was recorded during a summer thunderstorm.

Figure 5-2 portrays annual wind roses for three locations across SNL/NM. A wind rose is a graphical presentation of wind speed and direction frequency distribution. Wind direction is the true bearing when facing the wind (the direction from which the wind is blowing). As shown in the figures, wind directions and speeds vary across SNL/NM. The annual wind frequency distribution for TA-I shows a different pattern, with the greatest direction frequency from the east and east-northeast. The annual frequency distribution data mask the diurnal pattern of wind flow common through many areas of SNL/NM. Figure 5-3 shows the day and night wind frequency distributions for A36.

In general, areas closer to the mountains or canyons experience greater frequency of winds coming from the easterly directions (northeast through southeast) at night. Daytime wind patterns are not as pronounced but generally flow toward the mountains or channel into the canyons. In most areas, the nighttime wind direction frequency produces the maximum annual direction frequency.

A comparison of A15 tower wind-speed data with the rest of the network (Appendix A, Tables A-2 through A-8) reveals the effects of buildings on wind speed. For the 7 months of data recorded at the A15 tower, the average wind speed at the site was consistently the lowest speed across the network. The greatest frequency of calm conditions were recorded at this site, but the highest monthly maximum winds were also found there (coming down Tijeras Canyon) except for the severe thunderstorm wind at ST6 in August.

Pasquill-Gifford stability classes are calculated for use in atmospheric dispersion estimates. Stability classes for tower data were calculated using the sigma theta technique (EPA 1987), which categorizes the stability class as a function of standard deviation of horizontal wind direction and mean horizontal wind speed. Stability classes range from extremely unstable (A) to moderately stable (F). These classes are used in regulatory modeling to estimate how much a plume will spread over time and space. In general, the more stable the atmosphere is, the less potential for plume spread, creating higher plume concentrations. Table 5-2 shows the percentage occurrence of stability classes at A36. When wind speeds are greater than $6.0 \mathrm{~m} / \mathrm{s}$, the stability class defaults to $D$ regardless of the sigma theta value. The wind speed distribution is the major cause of the high percentage of D stability classes. 

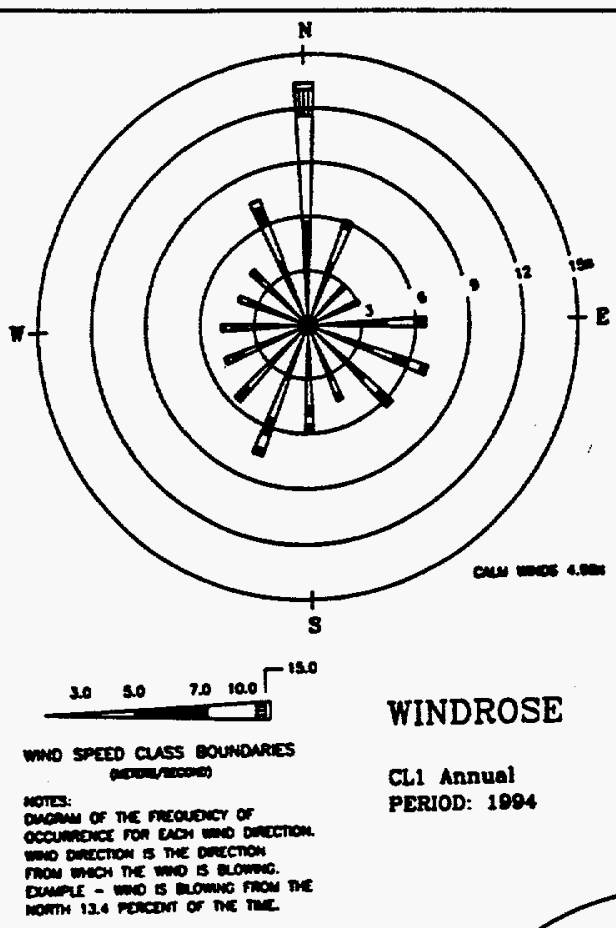

WINDROSE

Chl Annual

PDRJOD: 1094
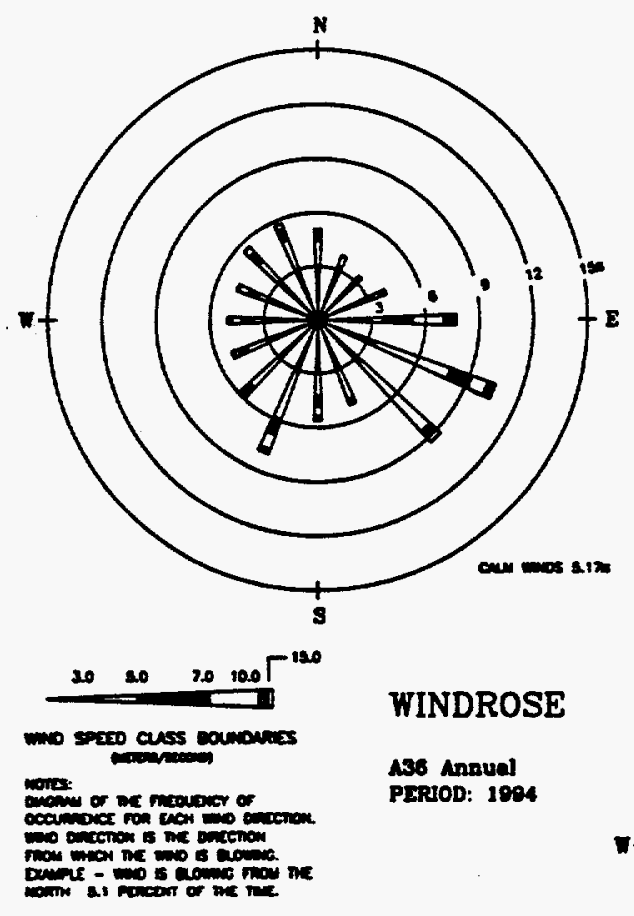

WINDROSE

As6 Ansual

PERIOD: 1004
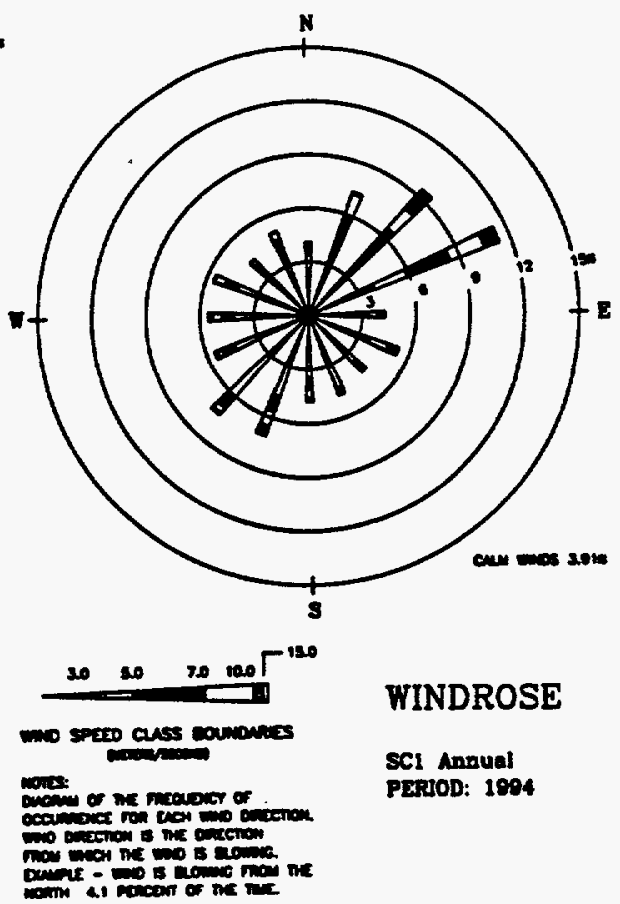

WINDROSE

SCI Annual

PERIOD: 1904

Figure 5-2. Annual Wind Roses for Towers CL1, A36, and SC1 

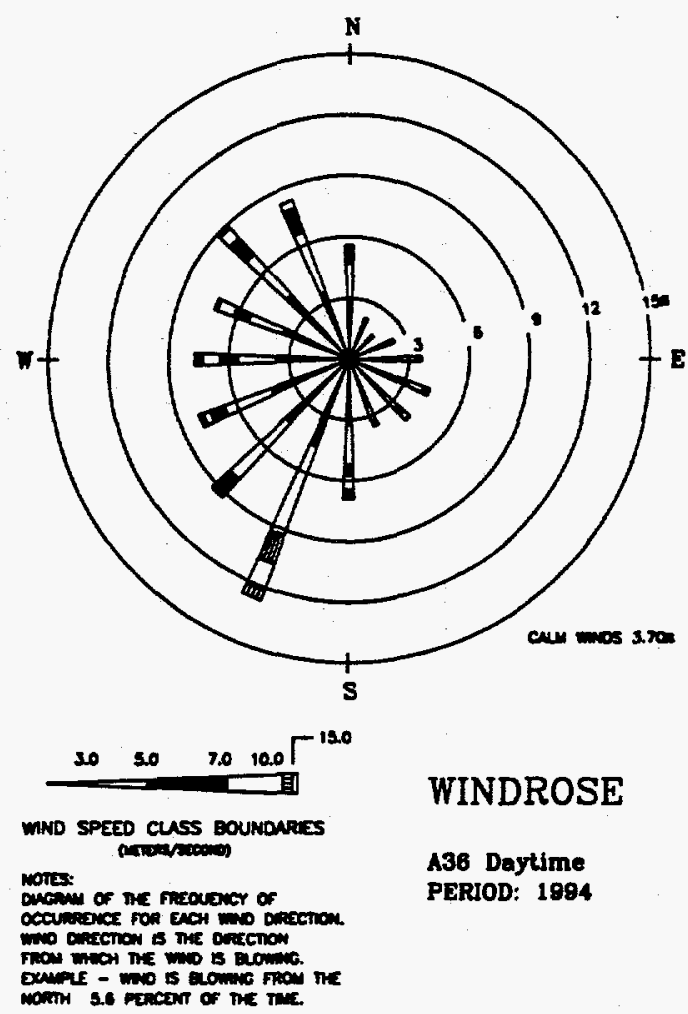

WINDROSE

A36 Daytime

PERIOD: 1994

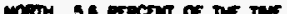
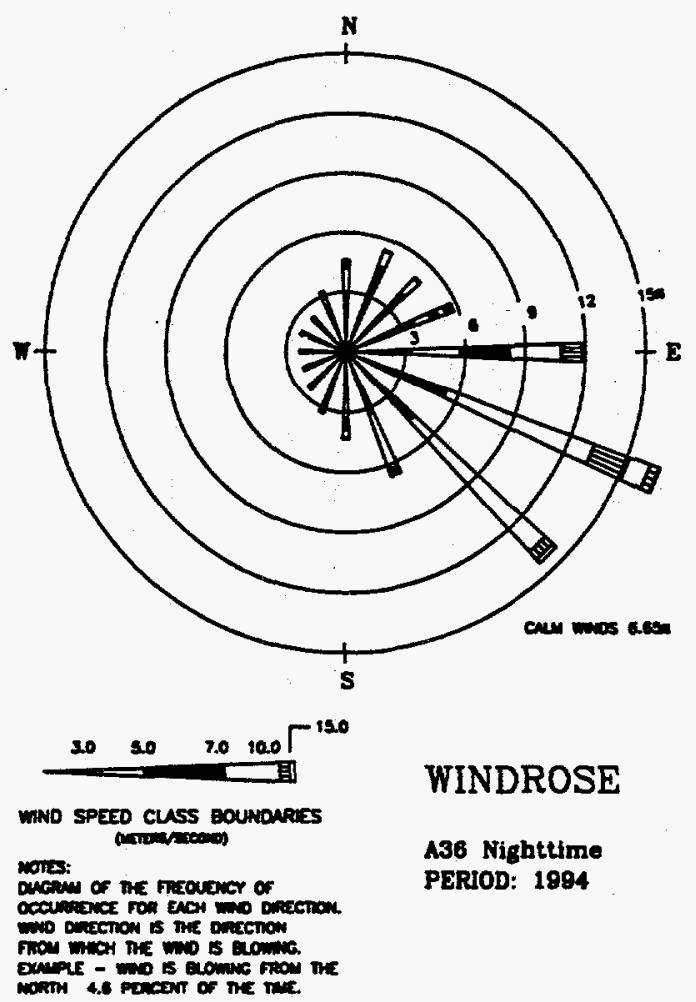

WINDROSE

A36 Nighttime

PERIOD: 1994

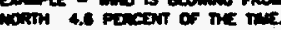

Figure 5-3. Day and Night Wind Frequency Distributions for Tower A36 
Table 5-2. Tower A36 Stability Class Frequency Distribution

Stability Class

Percent Occurrence

$\begin{array}{lr}\text { A } & 13.4 \\ \text { B } & 9.0 \\ \text { C } & 9.3 \\ \text { D } & 41.3 \\ \text { E } & 17.5 \\ \text { F } & 9.4\end{array}$

Appendix A, Table A-9, lists stability classes for the rest of the network towers. The stability classes were summarized from annual stability array (STAR) decks for each tower. Appendix A, Table A-10, includes the STAR deck for A36.

\subsection{AMBIENT AIR SURVEILLANCE PROGRAM}

The current ambient air surveillance program at SNL/NM commenced operations January 3, 1994. The ambient air surveillance program is one of two programs that constitute the CAN. This program is integral to compliance with 40 CFR 50, National Ambient Air Quality Standards (NAAQS), DOE Orders 5400.1 (DOE 1988a) and 5400.5 (DOE 1990a), and DOE guidelines outlined in DOE/EH-0173T (DOE 1991b). The program also follows 40 CFR 58 to ensure that data meet the requirements dictated for state monitoring programs.

The main objective of SNL/NM's ambient air surveillance program is collection of data to establish background concentration levels for pollutants of concern, show compliance with the NAAQS and local ambient air quality standards, and evaluate effects of laboratory emissions on the public and environment. The network includes one Criteria Pollutant Monitoring Station (CPMS), seven particulate matter (PM) monitoring stations, and four volatile organic compound (VOC) monitoring locations. An eighth PM monitor is collocated at the PVPM site. Figure 5-4 shows ambient air monitoring station locations.

The CPMS is used to perform continuous monitoring of sulfur dioxide $\left(\mathrm{SO}_{2}\right)$, carbon monoxide $(\mathrm{CO})$, nitrous oxides $\left(\mathrm{NO}_{\mathrm{x}}\right)$, and ozone $\left(\mathrm{O}_{3}\right)$. The $\mathrm{PM}$ monitors collect data on matter with a diameter equal to or less than 10 microns $\left(\mathrm{PM}_{10}\right)$. The $\mathrm{PM}_{10}$ sampling schedule is consistent with the national air sampling program. The frequency of sampling for the particulate network is a 24-hour (hr) sample, starting and ending at midnight, every sixth day. VOCs are sampled once a month for a 24 -hr period. 


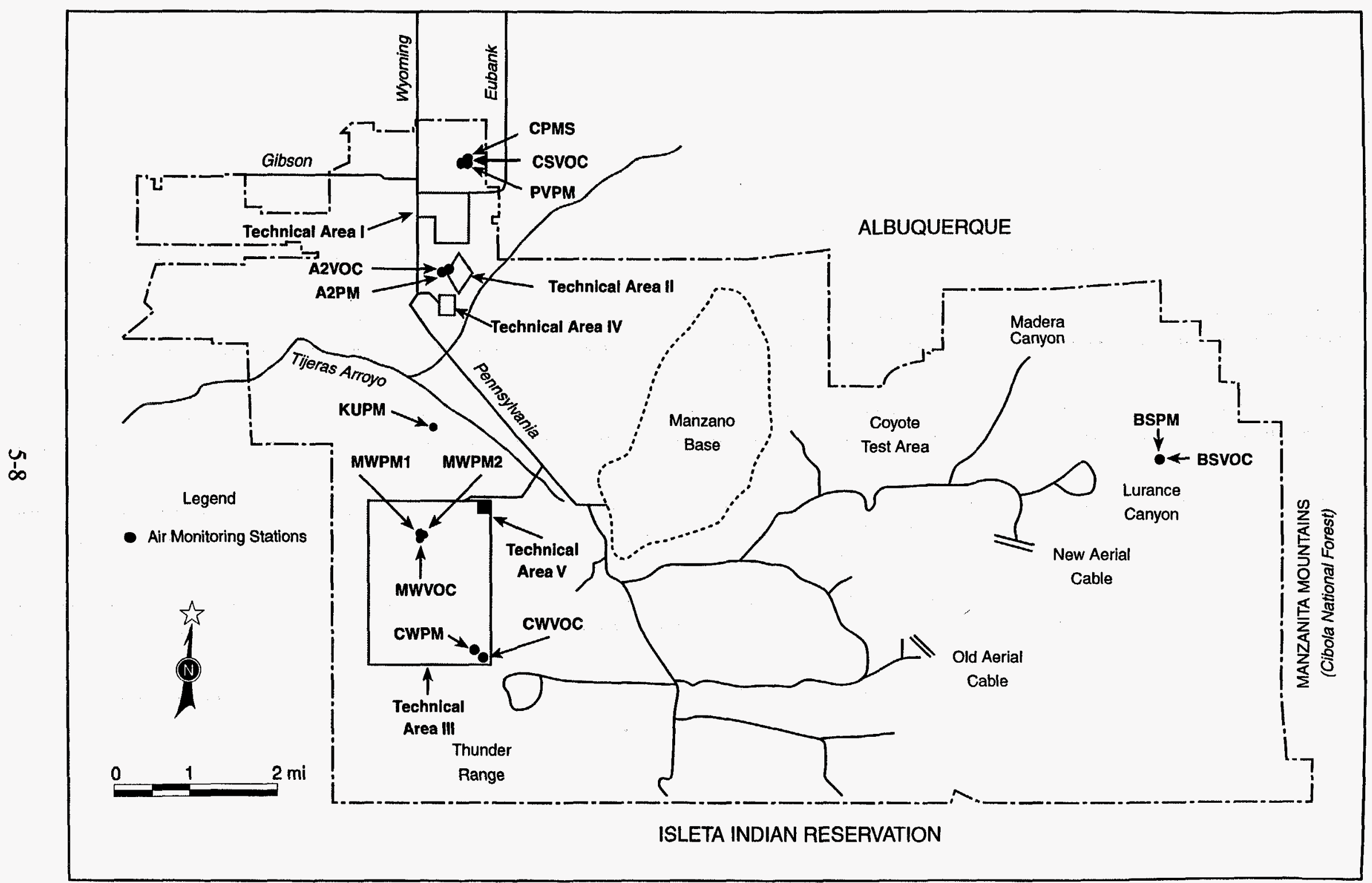

Figure 5-4. Ambient Air Monitoring Station Locations, SNL/NM 


\subsubsection{Ambient Air Monitoring Results}

5.2.1.1 Criteria Pollutants - The automated CPMS system compiles gaseous criteria pollutant information in hourly averages. Data recovery for 1994 was 91 percent. Table 5-3 lists the local, state, and federal air quality standards and monitored results. Annual standards cannot be violated, but short-term standards may be exceeded once a year. No standards were exceeded or violated in 1994.

Table 5-3. Criteria Pollutant Standards and SNL/NM Monitoring Results

\begin{tabular}{|c|c|c|c|c|c|c|}
\hline Pollutant & $\begin{array}{l}\text { Averaging } \\
\text { Time }\end{array}$ & Unit & $\begin{array}{c}\text { ABC } \\
\text { AAQS }^{*}\end{array}$ & $\mathrm{NMAQS}^{\dagger}$ & $\mathrm{NAAQS}^{\ddagger}$ & $\begin{array}{c}\text { Measured } \\
\text { Concentrations }\end{array}$ \\
\hline $\begin{array}{l}\text { Carbon } \\
\text { Monoxide }\end{array}$ & $\begin{array}{l}1 \text { hour } \\
8 \text { hours } \\
\text { Annual }\end{array}$ & $\begin{array}{l}\text { ppm } \\
\text { ppm } \\
\text { ppm }\end{array}$ & $\begin{array}{r}13 \\
4\end{array}$ & $\begin{array}{r}13.1 \\
8.7\end{array}$ & $\begin{array}{r}35 \\
9\end{array}$ & $\begin{array}{l}9.0 \\
4.3 \\
1.4\end{array}$ \\
\hline $\begin{array}{l}\text { Nitrogen } \\
\text { Dioxide }\end{array}$ & $\begin{array}{l}24 \text { hours } \\
\text { Annual }\end{array}$ & $\begin{array}{l}\text { ppm } \\
\text { ppm }\end{array}$ & $\begin{array}{l}0.062^{\S} \\
0.052^{\S}\end{array}$ & $\begin{array}{l}0.10 \\
0.05\end{array}$ & & $\begin{array}{l}0.041 \\
0.016\end{array}$ \\
\hline Nitrogen Oxides & Annual & ppm & & & 0.053 & 0.027 \\
\hline $\begin{array}{l}\text { Sulfur } \\
\text { Dioxide }\end{array}$ & $\begin{array}{c}3 \text { hours } \\
24 \text { hours } \\
\text { Annual }\end{array}$ & $\begin{array}{l}\text { ppm } \\
\text { ppm } \\
\text { ppm }\end{array}$ & $\begin{array}{l}0.032 \\
0.004\end{array}$ & $\begin{array}{l}0.10 \\
0.02\end{array}$ & $\begin{array}{l}0.50 \\
0.14^{\S} \\
0.03^{\S}\end{array}$ & $\begin{array}{l}0.0083 \\
0.002 \\
0.0003\end{array}$ \\
\hline $\begin{array}{l}\text { Ozone (photo } \\
\text { chemical } \\
\text { oxidants) }\end{array}$ & 1 hour & ppm & $(0.01)$ & $(0.06)$ & 0.12 & 0.096 \\
\hline $\mathrm{PM}_{10}$ & $\begin{array}{c}24 \text { hours } \\
\text { Annual }\end{array}$ & $\begin{array}{l}\mu \mathrm{g} / \mathrm{m}^{3} \\
\mu \mathrm{g} / \mathrm{m}^{3}\end{array}$ & $\begin{array}{r}150 \\
60\end{array}$ & $\begin{array}{r}150 \\
60\end{array}$ & $\begin{array}{r}150 \\
50\end{array}$ & $\begin{array}{l}66.00 \\
15.92\end{array}$ \\
\hline $\begin{array}{l}\text { Total Suspended } \\
\text { Particulates }\end{array}$ & $\begin{array}{l}7 \text { days } \\
30 \text { days }\end{array}$ & $\begin{array}{l}\mu \mathrm{g} / \mathrm{m}^{3} \\
\mu \mathrm{g} / \mathrm{m}^{3}\end{array}$ & & $\begin{array}{r}110 \\
90\end{array}$ & & $\begin{array}{l}\text { NA } \\
\text { NA }\end{array}$ \\
\hline $\begin{array}{l}\text { Lead } \\
\text { (heavy metals) }\end{array}$ & $\begin{array}{l}30 \text { days } \\
\text { Any quarter }\end{array}$ & $\begin{array}{l}\mu \mathrm{g} / \mathrm{m}^{3} \\
\mu \mathrm{g} / \mathrm{m}^{3}\end{array}$ & 3 & (10) & 1.5 & $\begin{array}{l}0.0843 \\
0.0667\end{array}$ \\
\hline \multicolumn{7}{|c|}{ 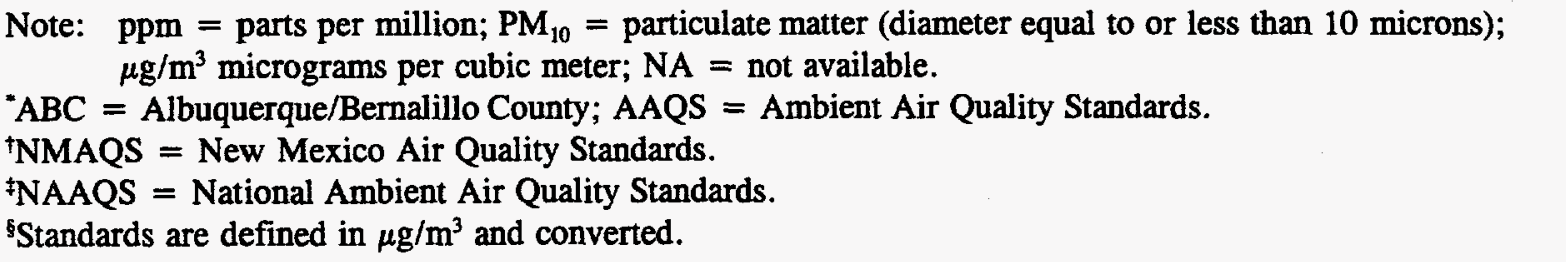 } \\
\hline
\end{tabular}

$\mathrm{PM}_{10}$ concentrations were low except for a few sampling days in July when hot, dry weather aided the production of airborne dust. A comparision of PM monitoring locations showed the highest 24-hr particulate loading occurred at the CPMS and CWPM stations. 
5.2.1.2 Particulate Matter Metals Analysis - The $\mathrm{PM}_{10}$ filters were grouped into monthly composites for the analyses listed in Table 5-4. Monthly composites varied from four to six filters per month throughout 1994, dependent upon the sampling schedule.

Table 5-4. $\mathrm{PM}_{10}$ Sample Analyses Conducted in 1994

\begin{tabular}{|c|c|c|c|c|c|c|}
\hline Site & $\begin{array}{l}\text { ICP } \\
\text { Metals }\end{array}$ & $\begin{array}{c}\text { Total } \\
\text { Uranium }\end{array}$ & $\begin{array}{c}\text { Gamma } \\
\text { Spec. }\end{array}$ & $\begin{array}{l}\text { Gross } \\
\text { Alpha }\end{array}$ & $\begin{array}{c}\text { Gross } \\
\text { Beta }\end{array}$ & Lead \\
\hline PVPM1 & $\mathrm{X}$ & & $\mathrm{X}$ & $\mathrm{X}$ & $\mathrm{X}$ & \\
\hline PVPM2 & $\mathrm{X}$ & & $X$ & $\mathrm{X}$ & $\mathrm{X}$ & \\
\hline CPMS & & & & & & $\mathrm{X}$ \\
\hline $\mathrm{A} 2 \mathrm{PM}$ & $\mathrm{X}$ & & $X$ & $X$ & $\mathrm{X}$ & \\
\hline KUPM & $\mathrm{X}$ & $\mathrm{X}$ & $\mathrm{X}$ & $\mathrm{X}$ & $\mathbf{X}$ & \\
\hline MWPME & $\mathbf{X}$ & $\mathrm{x}$ & $\mathbf{X}$ & $\mathrm{x}$ & $X$ & \\
\hline MWPMW & $\mathrm{X}$ & $\mathrm{X}$ & $\mathrm{X}$ & $\mathrm{X}$ & $\mathrm{X}$ & \\
\hline CWPM & $\mathrm{X}$ & & $\mathrm{X}$ & $\mathrm{X}$ & $\mathrm{X}$ & \\
\hline
\end{tabular}

Appendix A, Table A-11, lists the site-specific range and average of the analytical results for the $\mathrm{PM}_{10}$ particulate analysis. Table 5-5 contains the composited results for the site. Minor components included in filter composition (such as iron and potassium) were not subtracted from the samples. Generally, the analytical results showed metals characteristic of local soil composition.

5.2.1.3 Volatile Organic Compounds - VOC sampling commenced in March 1994. Data recovery for the whole VOC program was 97.5 percent; only one of 40 samples taken was invalidated due to leakage in shipping. The one invalid canister came from the TA-II sampling site. The samples were analyzed for 25 species of VOCs and total non-methane hydrocarbon (TNMHC). Appendix A, Table A-12, lists the site-specific range and average of the analytical results. Table 5-6 contains a composite of the eight most frequently found compounds. Generally, slightly higher concentrations of VOCs were recorded at the CPMS site, as shown by comparing the minimum concentrations found at each site listed in Appendix A. These higher concentrations were expected because the CPMS site is near a busy intersection and across the street from the motor pool where vehicle maintenance is performed. The VOCs observed at SNL/NM are products (or byproducts) of fossil fuels or found in cleaning solvents. 
Table 5-5. Composited Results for the $\mathrm{PM}_{10}$ Network

\begin{tabular}{|c|c|c|c|c|}
\hline & Minimum & Maximum & Average & $\begin{array}{l}\text { Standard } \\
\text { Deviation }\end{array}$ \\
\hline \multicolumn{5}{|l|}{ Analyte $\left(\mu \mathrm{g} / \mathrm{m}^{3}\right)$} \\
\hline Arsenic & 0.002 & 0.036 & 0.015 & 0.0125 \\
\hline Barium & 0.005 & 0.728 & 0.178 & 0.1863 \\
\hline Beryllium & 0.000 & 0.042 & 0.002 & 0.0046 \\
\hline Cadmium & 0.000 & 0.010 & 0.003 & 0.0024 \\
\hline Chromium & 0.000 & 0.307 & 0.065 & 0.0956 \\
\hline Cobalt & 0.000 & 0.012 & 0.002 & 0.0026 \\
\hline Copper & 0.008 & 0.157 & 0.036 & 0.0279 \\
\hline Iron & 0.088 & 2.448 & 0.817 & 0.6570 \\
\hline Lead & 0.001 & 0.289 & 0.025 & 0.0362 \\
\hline Manganese & 0.003 & 0.105 & 0.034 & 0.0296 \\
\hline Molybdenum & 0.000 & 0.080 & 0.016 & 0.0253 \\
\hline Nickel & 0.001 & 0.036 & 0.012 & 0.0117 \\
\hline Potassium & 0.416 & 30.743 & 11.962 & 10.6046 \\
\hline Selenium & 0.002 & 0.040 & 0.016 & 0.0124 \\
\hline Silver & 0.000 & 0.006 & 0.002 & 0.0017 \\
\hline Thallium & 0.004 & 0.519 & 0.119 & 0.1529 \\
\hline Vanadium & 0.000 & 0.025 & 0.003 & 0.0032 \\
\hline Zinc & 0.006 & 0.510 & 0.082 & 0.0939 \\
\hline \multicolumn{5}{|c|}{ Analyte $\left(\mathrm{pCi} / \mathrm{m}^{3}\right)$} \\
\hline Gross Alpha & 0.000 & 0.047 & 0.011 & 0.0109 \\
\hline Gross Beta & 0.005 & 0.172 & 0.049 & 0.0465 \\
\hline Beryllium-7 & 0.028 & 2.006 & 0.240 & 0.3197 \\
\hline Potassium-40 & -0.010 & 1.244 & 0.062 & 0.1792 \\
\hline Uranium, total & 0.000 & 0.005 & 0.002 & 0.0015 \\
\hline
\end{tabular}


Table 5-6. Results (in ppbv) for VOCs Observed Most Frequently at Sandia National Laboratories/New Mexico

\begin{tabular}{|c|c|c|c|c|c|c|c|c|c|c|c|c|}
\hline \multirow{3}{*}{$\begin{array}{l}\text { Compound } \\
\text { Chloromethane }\end{array}$} & \multicolumn{3}{|c|}{$\operatorname{CPMS}(10)^{\circ}$} & \multicolumn{3}{|c|}{ TA-11 $(9)^{*}$} & \multicolumn{3}{|c|}{$\operatorname{MWL}(10)^{*}$} & \multicolumn{3}{|c|}{ CWL (10)* } \\
\hline & \multicolumn{2}{|c|}{ Range } & \multirow{2}{*}{$\begin{array}{l}\text { Average } \\
0.46\end{array}$} & \multicolumn{2}{|c|}{ Range } & \multirow{2}{*}{$\begin{array}{c}\overline{\text { Average }} \\
0.58\end{array}$} & \multicolumn{2}{|c|}{ Range } & \multirow{2}{*}{$\begin{array}{l}\text { Average } \\
0.77\end{array}$} & \multicolumn{2}{|c|}{ Range } & \multirow{2}{*}{$\begin{array}{l}\text { Average } \\
0.43\end{array}$} \\
\hline & 0.20 & 0.90 & & 0.30 & 1.70 & & 0.10 & 3.00 & & 0.10 & 1.30 & \\
\hline Dichlorodifluoromethane & 0.30 & 1.10 & 0.60 & 0.07 & 1.20 & 0.56 & 0.10 & 1.10 & 0.54 & 0.30 & 0.90 & 0.52 \\
\hline n-Butane & 0.80 & 3.10 & 1.57 & 0.30 & 2.00 & 0.78 & 0.20 & 0.60 & 0.39 & 0.20 & 0.90 & 0.37 \\
\hline Isopentane & 1.10 & 7.50 & 2.70 & 0.50 & 16.60 & 3.03 & 0.30 & 12.60 & 2.00 & 0.10 & 0.80 & 0.41 \\
\hline Acetone & 0.50 & 7.90 & 2.33 & 0.40 & 3.50 & 1.25 & 0.20 & 27.60 & 6.11 & 0.40 & 6.00 & 2.26 \\
\hline Trichlorofluoromethane & 0.10 & 0.40 & 0.22 & 0.05 & 0.40 & 0.20 & 0.08 & 0.40 & 0.21 & 0.07 & 0.40 & 0.18 \\
\hline Benzene & 0.40 & 2.00 & 0.78 & 0.20 & 0.70 & 0.37 & 0.10 & 0.40 & 0.25 & 0.10 & 0.40 & 0.25 \\
\hline Toluene & 0.50 & 1.60 & 0.97 & 0.20 & 1.00 & 0.48 & 0.20 & 1.20 & 0.39 & 0.10 & 0.40 & 0.25 \\
\hline $\begin{array}{l}\text { Total non-methane } \\
\text { hydrocarbon (TNMHC) }\end{array}$ & 9.80 & $752^{\dagger}$ & 95.45 & 3.60 & 24.20 & 9.99 & 2.40 & 26.60 & 9.79 & 1.30 & 11.30 & 5.04 \\
\hline $\begin{array}{l}\text { Note: ppbv = parts per } b \\
\text { "Number of samples analy } \\
\text { tValue caused by ethanol }\end{array}$ & $\begin{array}{l}\text { on in } \\
\text { in } 1 \text { S }\end{array}$ & $\begin{array}{l}\text { volume. } \\
94 . \\
\text { nated co }\end{array}$ & ounds. & & & & & & & & & \\
\hline
\end{tabular}




\subsection{AIR EMISSIONS RADIOLOGICAL MONITORING}

Several facilities within SNL/NM routinely generate radioactive effluents or emissions. A total of 11 facilities at SNL/NM reported airborne releases of radionuclides in 1994. Ten of the eleven sources were point source releases which occurred as stack emissions. The eleventh release source was a diffuse area source with a measurable annual release. Table 5-7 summarizes the radionuclides, quantity of release, and release type (point or diffuse) by facility for 1994.

\subsubsection{Radioactive Effluent Air Monitoring}

Calculations and operational measurements indicate that small quantities of $\mathrm{H}-3$, nitrogen-13 ( $\mathrm{N}-13)$, oxygen-15 (O-15), and argon-41 (Ar-41) emissions were released to the atmosphere along with additional, less significant, radionuclides as a result of SNL/NM 1994 operations. Ar-41 was released from the Annular Core Research Reactor (ACRR) and Sandia Pulsed Reactor-III (SPR-III) in TA-V as a result of neutron activation of stable, naturally occurring Ar-40. The High-Energy Radiation Megavolt Electron Source-III (HERMES-III) accelerator in TA-IV released N-13 and O-15 during routine operation as a result of X-ray activation of air. Based on process knowledge and calculation, the Neutron Generator Test Facility (NGTF) released low amounts of tritium (H-3). H-3 was measured both in 1992 and 1993 at the Mixed Wast Landfill (MWL) in TA-III (Radian 1994). Figure 5-5 summarizes the annual air emissions from 1978 to 1994.

\subsubsection{Technical Area V Reactors}

The SPR-III released Ar-41 from the reactor stack during 1994 operations. The SPR-III exhaust stack consists of a prefilter, a high-efficiency particulates in air (HEPA) filter, and a charcoal filter. A radiological air monitor (RAM) is located on the stack exhaust downstream of the filter banks.

Gamma/beta surveys are routinely performed on the filters to determine dose rates. Gaseous grab samples and particulate samples can be collected, if necessary, for more detailed gamma spectral analysis.

The ACRR also releases Ar-41 as a result of reactor operations. The ACRR has two exhaust stacks: one stack exhausts the room air in the high bay, and the second stack, the central cavity purge system, evacuates the reactor experimental cavity. There are three continuous air monitors (CAMs) that sample the cavity purge stack, high bay room air, and the reactor pool for beta emissions. The exhaust system is equipped with prefilters, HEPA filters, and charcoal filters. Gamma/beta surveys are routinely performed on the filters to determine dose rates. Also, gaseous grab samples and particulate samples can be collected, if necessary, for more detailed gamma spectral analysis. An air monitoring system installed in the cavity purge stack has the capability to monitor gross alpha, gross beta, iodine, and Ar-41. 
Table 5-7. Summary of Radionuclide Releases for 1994

\begin{tabular}{|c|c|c|c|}
\hline Facility & Source Type & Radionuclide & Release (Ci/yr) \\
\hline $\begin{array}{l}\text { Annular Core Research } \\
\text { Reactor (ACRR), TA-V, Bldg. } 6588\end{array}$ & Point & $\begin{array}{l}\text { Tritium } \\
\text { Argon-41 } \\
\text { Krypton-83m } \\
\text { Krypton-85 } \\
\text { Krypton-85m } \\
\text { Krypton-87 } \\
\text { Krypton-88 } \\
\text { Rubidium-86 } \\
\text { Rubidium-87 } \\
\text { Rubidium-88 } \\
\text { Rubidium-89 } \\
\text { Xenon-131m } \\
\text { Xenon-133 } \\
\text { Xenon-133m } \\
\text { Xenon-135 } \\
\text { Xenon-135m } \\
\text { Xenon-137 } \\
\text { Xenon-138 }\end{array}$ & $\begin{array}{l}1.1 \times 10^{-5} \\
2.1 \\
1.7 \times 10^{-2} \\
5.7 \times 10^{-6} \\
6.3 \times 10^{-2} \\
3.2 \times 10^{-2} \\
0.1 \\
1.5 \times 10^{-7} \\
1.4 \times 10^{-14} \\
1.9 \times 10^{-2} \\
4.8 \times 10^{-5} \\
5.8 \times 10^{-6} \\
3.4 \times 10^{-2} \\
1.7 \times 10^{-3} \\
0.4 \\
5.1 \times 10^{-3} \\
2.2 \times 10^{-27} \\
1.4 \times 10^{-4}\end{array}$ \\
\hline $\begin{array}{l}\text { Calibration Laboratory, TA-I, } \\
\text { Bldg. } 869\end{array}$ & Point & Tritium & $1.5 \times 10^{-6}$ \\
\hline $\begin{array}{l}\text { Chemical Processing Laboratory, } \\
\text { TA-III, Bldg. } 6600\end{array}$ & Point & $\begin{array}{l}\text { Sodium-22 } \\
\text { Gadolinium-153 } \\
\text { Americium-241 }\end{array}$ & $\begin{array}{l}2.4 \times 10^{-12} \\
1.0 \times 10^{-13} \\
1.0 \times 10^{-13}\end{array}$ \\
\hline $\begin{array}{l}\text { Metal Tritide Shelf-Life } \\
\text { Laboratory, TA-I, Bldg. } 891\end{array}$ & Point & Tritium & $5.0 \times 10^{-9}$ \\
\hline $\begin{array}{l}\text { Sandia Pulsed Reactor (SPR), } \\
\text { TA-V, Bldg. } 6591\end{array}$ & Point & Argon-41 & 0.55 \\
\hline $\begin{array}{l}\text { High-Energy Radioactive } \\
\text { Megavolt Electron Source-III } \\
\text { (HERMES-III), TA-IV, Bldg. } 970\end{array}$ & Point & $\begin{array}{l}\text { Nitrogen-13 } \\
\text { Oxygen-15 }\end{array}$ & $\begin{array}{l}2.32 \\
3.0 \times 10^{-2}\end{array}$ \\
\hline $\begin{array}{l}\text { Particle Beam Fusion Accelerator-II } \\
\text { (PBFA-II), TA-IV, Bldg. } 983\end{array}$ & Point & $\begin{array}{l}\text { Nitrogen-13 } \\
\text { Oxygen-15 }\end{array}$ & $\begin{array}{l}4.2 \times 10^{-2} \\
5.0 \times 10^{-3}\end{array}$ \\
\hline Time of Flight (TOF), TA-I, Bldg. 891 & 1 Point & Tritium & $6.0 \times 10^{-5}$ \\
\hline
\end{tabular}


Table 5-7. Summary of Radionuclide Releases for 1994 (Concluded)

\begin{tabular}{|c|c|c|c|}
\hline Facility & Source Type & Radionuclide & Release (Ci/yr) \\
\hline \multirow{6}{*}{$\begin{array}{l}\text { Tandem Van de Graff Accelerator, } \\
\text { TA-I, Bldg. } 884\end{array}$} & Point & Oxygen-14 & $3.2 \times 10^{-7}$ \\
\hline & & Oxygen-15 & $2.1 \times 10^{-3}$ \\
\hline & & Nitrogen-13 & $1.2 \times 10^{-4}$ \\
\hline & & Fluorine-17 & $8.0 \times 10^{-6}$ \\
\hline & & Fluorine-18 & $1.2 \times 10^{-5}$ \\
\hline & & Carbon-11 & $5.3 \times 10^{-5}$ \\
\hline \multirow{12}{*}{$\begin{array}{l}\text { Radiation Laboratory, TA-I, } \\
\text { Bldg. } 805\end{array}$} & Point & Tritium & $1.0 \times 10^{-5}$ \\
\hline & & Carbon-13 & 0.20 \\
\hline & & Carbon-14 & $2.0 \times 10^{-12}$ \\
\hline & & Nitrogen-13 & $1.0 \times 10^{-8}$ \\
\hline & & Nitrogen-15 & 0.10 \\
\hline & & Nitrogen-16 & $2.0 \times 10^{-7}$ \\
\hline & & Americium-241 & $1.0 \times 10^{-11}$ \\
\hline & & Argon-41 & $1.0 \times 10^{-9}$ \\
\hline & & Curium-244 & $7.0 \times 10^{-11}$ \\
\hline & & Lead-210 & $4.0 \times 10^{-13}$ \\
\hline & & Plutonium-239 & $6.0 \times 10^{-12}$ \\
\hline & & Uranium-natural & $4.0 \times 10^{-12}$ \\
\hline $\begin{array}{l}\text { Mixed Waste Landfill (MWL), } \\
\text { TA-III }\end{array}$ & Diffuse & Tritium & 0.29 \\
\hline
\end{tabular}

The Hot Cell Facility (HCF) stack contains filter banks equipped with a prefilter and HEPA filters. RAMs are located on the filter banks on both the cold exhaust and hot exhaust. An air monitoring system installed in the HCF exhaust stack has the capability to monitor gross alpha, gross beta, iodine, and krypton. Gaseous grab samples and particulate samples can be collected and analyzed using gamma spectroscopy. The HCF performed no operations in 1994.

\subsubsection{Technical Area IV Facility}

The HERMES-III gamma-ray simulator produces the radioactive gases $\mathrm{N}-13$ and $0-15$ as a result of the photoactivation of the surrounding air. The HERMES-III stack is equipped with an air monitoring system capable of monitoring HERMES-III gas emissions. The monitor was tested in 1994 and preliminary periodic measurements were performed. 


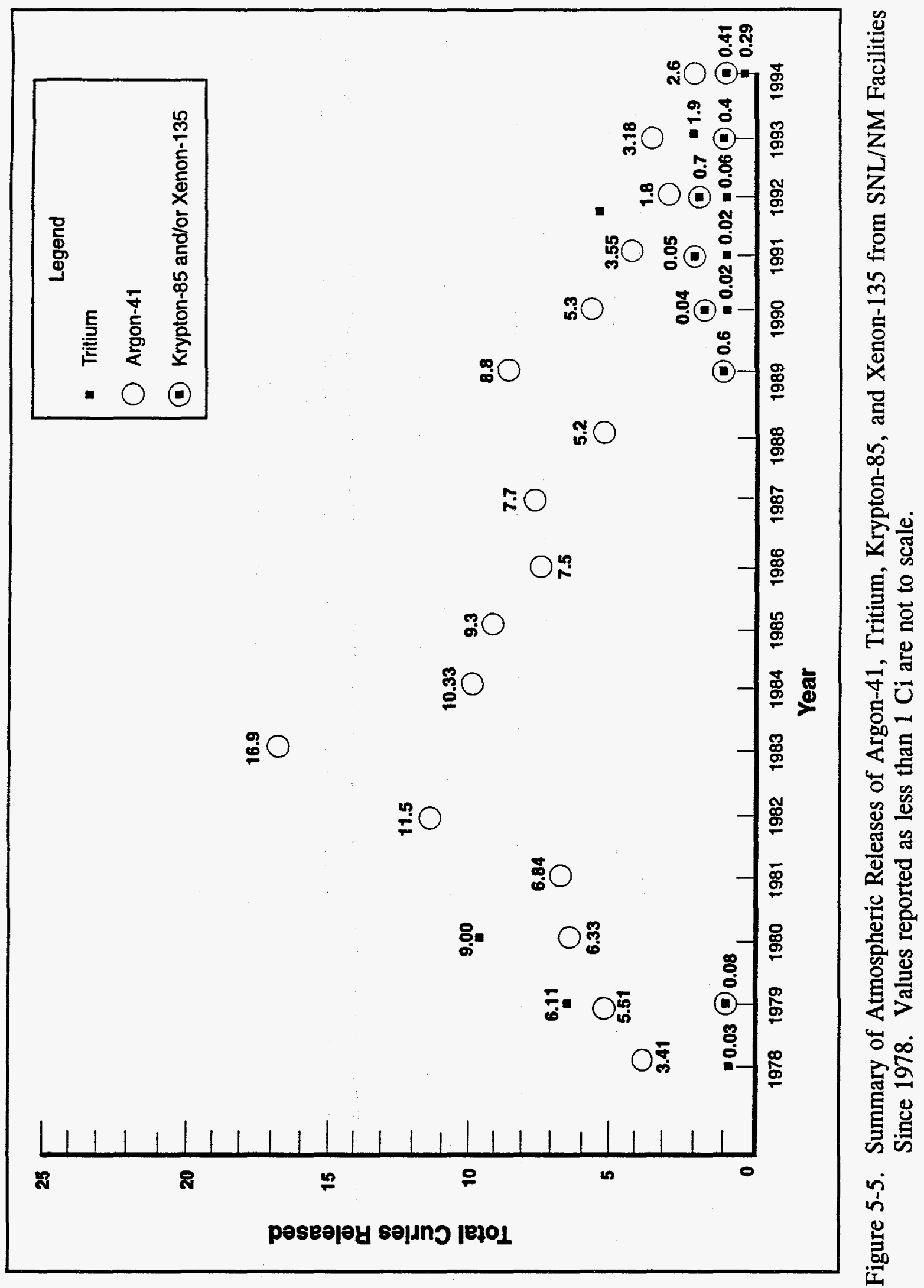




\subsection{AIR QUALITY RADIOLOGICAL MONITORING RESULTS}

Compressed air samples and particulate samples were taken in 1994 at the ACRR, SPR-III, and $\mathrm{HCF}$ as part of the confirmatory source measurements required by National Emission Standards for Hazardous Air Pollutants (NESHAP) regulations (40 CFR 61). NESHAP regulations require continuous monitoring for an EDE (effective dose equivalent) greater than or equal to 0.1 millirem per year (mrem/yr), and periodic monitoring for an EDE less than $0.1 \mathrm{mrem} / \mathrm{yr}$. Based on the confirmatory measurements taken at all three facilities, the EDE was calculated to be less than the 0.1-mrem/yr limit (SNL 1994e). Periodic monitoring, therefore, will be performed at the SPR-III, ACRR, and HCF. The ACRR and HCF are each equipped with a continuous stack monitor as a best management practice. The stack monitors will provide periodic measurement data for these facilities. Compressed gas sampling and particulate sampling will be performed periodically for monitoring at SPR-III. Compressed gas sampling will be performed annually to confirm the periodic measurements for all three facilities (HCF, ACRR, and SPR-III). The results of the periodic and confirmatory measurements will be used to report the annual emissions.

The HERMES-III source terms were also confirmed for NESHAP compliance in 1994. HERMES-III is equipped with a continuous stack monitor as a best management practice. The stack monitor was calibrated using a calibration jig. The source terms were confirmed by comparing the stack monitor measurements and the confirmatory measurements. The EDE was calculated to be much less than $0.1 \mathrm{mrem} / \mathrm{yr}$ (Culp 1994); therefore, only periodic monitoring is required for HERMES-III. Periodic measurements taken using the stack monitor will be confirmed by gamma spectroscopy measurements to provide results for use in future release reports.

\subsection{ASSESSMENT OF POTENTIAL DOSE TO THE PUBLIC}

The U.S. Environmental Protection Agency (EPA) promulgated the NESHAP (40 CFR 61, Subpart H) for radionuclides in December 1989 , which requires the radiation dose to be calculated for the maximum exposed individual (MEI) at a public access location including an office, school, or residence. A comprehensive survey of all public access locations on Kirtland Air Force Base (KAFB) was conducted in 1990 to address this requirement. In addition, a determination was made that all non-SNL/NM personnel who work or live on KAFB are considered "members of the public" as defined by DOE Order 5400.5 (DOE 1990a). The 1994 dose assessment was performed for KAFB receptors including residences, businesses, and other locations where non-SNL/NM personnel abide or reside.

All dose calculations presented in this section were performed using the EPA CAP88-PC computer code (EPA 1991). The cumulative dose at each receptor location was calculated to be well below the EDE limit of $10 \mathrm{mrem} / \mathrm{yr}$ for the maximum exposed individual.

\subsubsection{Air Emission Sources}

As stated in Section 5.3, a total of 11 facilities at SNL/NM reported airborne releases of radionuclides in 1994. Ten of the eleven sources were point source releases which occurred 
as stack emissions. The eleventh release source was a diffuse area source with a measurable annual release. Table 5-7 summarizes the radionuclides, quantity of release, and release type (point or diffuse) by facility for 1994. Figure 5-6 shows the locations of facilities reporting radionuclide air emissions in 1994. A total of 2.6 curies (Ci) of Ar-41, 2.4 Ci of N-13, 0.037 $\mathrm{Ci}$ of O-15, and $0.29 \mathrm{Ci}$ of $\mathrm{H}-3$ were released into the atmosphere in 1994 as a result of SNL/NM operations. Smaller amounts of additional radionuclides were also released. Many of the radionuclides released are of such short half-lives (e.g., 10 minutes [min] for $\mathrm{N}-13,15$ min for rubidium-88 [Rb-88]) that radioactive decay during transport reduces doses at most of the receptor locations considered.

\subsubsection{Public Receptors}

The population of the four KAFB housing areas is approximately 6477 . The nonresidential areas include security offices, guard gates, credit unions, banks, restaurants, the KAFB landfill, golf course, U.S. Army Field Offices at Kirtland Underground Munitions Storage Complex (KUMSC), Manzano-area offices, Inhalation Toxicology Research Institute (ITRI), Rinchem, Raytheon/Defense Nuclear Agency (DNA), and other U.S. Air Force and Army research facilities and engineering offices (LATA 1991). The EDE was calculated for public receptors on KAFB in addition to locations outside KAFB boundaries. Using 1990 population census data, population doses were calculated for KAFB residents and all other people living within a 50-mile (mi) radius of SNL/NM.

\subsubsection{Meteorological Data}

Meteorological data used in 1994 for the dose assessment were obtained from meteorological stations located near the emission sources at SNL/NM. These site-specific data consist of over 8000 hourly meteorological observations of wind direction, wind speed, and stability class (inferred from wind and solar insolence data), and form a normalized distribution from which all wind and stability frequency of occurrence data are derived. The 1994 SNL/NM meteorological station data were used to create STAR data files which were incorporated into the CAP88-PC computer code (EPA 1991) for the dose assessment. Other meteorological data from the on-site stations used in the CAP88-PC code include average annual precipitation and temperature.

\subsubsection{Demographic Data}

The categories of demographic data include population, beef cattle, dairy cattle, and food crops used for human consumption. These four parameters were calculated for each of the CAP88-PC gridded zones (total of 80). In general, demographic data are available by county. The densities for population, beef cattle, dairy cattle, and food crops were calculated as the quotient of the most recent county data and the county land area. For 1994 calculations, 1990 census (DOC, 1992) and 1988 agricultural data were used. These calculations were based on a total of 571,677 people, 32,335 beef cattle, 7,290 dairy cattle, and $2.4 \times 10^{8}$ square meters $\left(\mathrm{m}^{2}\right)$ of food crops from the surrounding nine counties (LATA 1991). 


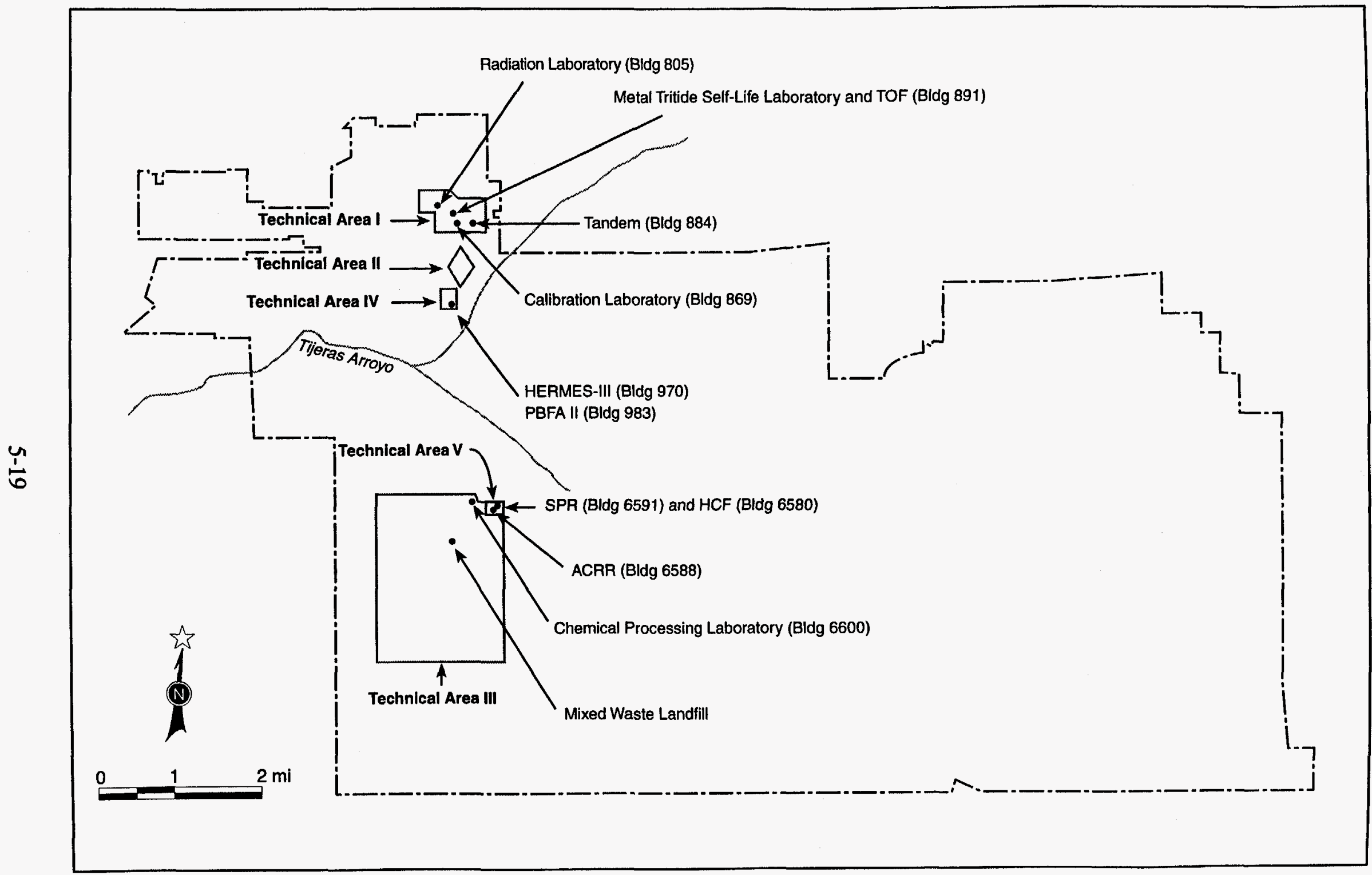

Figure 5-6. Facilities at SNL/NM Reporting Radionuclide Air Releases in 1994 


\subsubsection{Results of the Dose Assessment}

A calculation of the maximum exposed member of the public is required annually under the NESHAP regulation, 40 CFR 61, Subpart $H$. The regulation requires that the cumulative EDE from exposure to all site-wide radionuclide releases not exceed $10 \mathrm{mrem} / \mathrm{yr}$.

SNL/NM releases occurred from eleven different sources located in four different technical areas. As a result, many different receptor locations were evaluated as suspected locations of maximum exposure. In all, 24 locations were evaluated. These locations are in either off-site or on-site areas where members of the public are known to abide or reside. The term "receptor" was conservatively assumed to include members of the military, their dependents, contractors, and other non-SNL/NM personnel who work at locations around KAFB. The offsite and on-site SNL/NM receptors are listed in Tables 5-8 and 5-9, respectively. Figure 5-7 shows off-site and boundary receptors.

The dose contributions from each of the radionuclide sources were combined to yield an overall cumulative dose for the MEI. Eleven independent release sources, consisting of ten point sources and a single diffuse source, were determined to contribute to the MEI dose in 1994. Release amounts from individual facilities at SNL/NM were determined from either calculations based on measured stack parameters or from calculations. Tables 5-8 and 5-9 list SNL/NM radionuclide sources.

The dose assessment results showed the KUMSC, $1600 \mathrm{~m}$ northwest of TA-V, to be the location of the MEI. The EDE to the MEI was calculated to be $5.3 \times 10^{-4} \mathrm{mrem} / \mathrm{yr}$. This dose results primarily from exposure to $\mathrm{N}-13$ released from the High-Energy Radiation Megavolt Electron Source-III (HERMES-III) reactor and Ar-41 released from the ACRR. A significant contribution to the dose also arises from exposure to $\mathrm{H}-3$ released from the diffuse source in the MWL. The cumulative MEI dose of $5.3 \times 10^{-4} \mathrm{mrem} / \mathrm{yr}$ is well below the NESHAP dose standard of $10.0 \mathrm{mrem} / \mathrm{yr}$. Individual doses to the off-site and on-site SNL/NM receptors are presented in Tables 5-8 and 5-9, respectively.

\subsubsection{Population Dose at Kirtland Air Force Base}

A population dose resulting from exposure to all SNL/NM routine radiological emissions was calculated for KAFB residents. Because there are only a few residential neighborhoods on $\mathrm{KAFB}$, the KAFB population dose was determined based on the maximum individual dose calculated for each of the four KAFB housing compounds.

A 100-percent occupancy rate was conservatively assumed for all housing units, yielding a total KAFB population of 6477 . The population dose for each KAFB housing unit was calculated as the product of the housing unit population and the maximum housing unit individual dose (calculated by the CAP88-PC code) (EPA 1991). The housing unit population doses were then summed to obtain a composite KAFB population dose. An annual composite population dose of $5.1 \times 10^{-4}$ person-rem was estimated for KAFB. This population dose results primarily from exposure to $\mathrm{Ar}-41, \mathrm{~N}-13$, and $\mathrm{H}-3$. 
Table 5-8. Annual Effective Dose Equivalent (mrem/yr) to Off-Site and Boundary Receptors

\begin{tabular}{|c|c|c|c|c|c|c|c|c|c|}
\hline Receptor & $\begin{array}{l}\text { Bldg. 891, TOF } \\
\text { Laboratory and } \\
\text { Metal Tritide } \\
\text { Laboratory }\end{array}$ & $\begin{array}{l}\text { Bldg. } 805, \\
\text { Radiation } \\
\text { Laboratory }\end{array}$ & $\begin{array}{c}\text { Bldg. 884, } \\
\text { Tandem }\end{array}$ & $\begin{array}{l}\text { Bldg. } 869, \\
\text { Calibration } \\
\text { Laboratory } \\
\end{array}$ & $\begin{array}{c}\text { Mixed Waste } \\
\text { Landfill }\end{array}$ & $\begin{array}{l}\text { Bldg. 6600, } \\
\text { Chemical } \\
\text { Processing } \\
\text { Laboratory }\end{array}$ & $\begin{array}{l}\text { Bldg. 970/983, } \\
\text { HERMES-III } \\
\text { and PBFA-II }\end{array}$ & $\begin{array}{c}\text { Bldg. 6588, } \\
\text { ACRR and } \\
\text { SPR }\end{array}$ & Total Dose \\
\hline Tijeras Arroyo & $1.4 \times 10^{-9}$ & $1.2 \times 10^{-9}$ & $6.4 \times 10^{-10}$ & $5.1 \times 10^{-11}$ & $1.8 \times 10^{-5}$ & $3.7 \times 10^{-12}$ & $1.7 \times 10^{-5}$ & $1.1 \times 10^{-4}$ & $1.5 \times 10^{-4}$ \\
\hline City Landfill & $7.0 \times 10^{-10}$ & $4.7 \times 10^{-10}$ & $1.3 \times 10^{-10}$ & $2.3 \times 10^{-11}$ & $7.0 \times 10^{-6}$ & $1.2 \times 10^{-12}$ & $1.7 \times 10^{-6}$ & $3.2 \times 10^{-5}$ & $4.1 \times 10^{-5}$ \\
\hline $\begin{array}{l}\text { Albuquerque } \\
\text { International } \\
\text { Sunport (West } \\
\text { End) }\end{array}$ & $3.1 \times 10^{-9}$ & $3.7 \times 10^{-9}$ & $6.0 \times 10^{-9}$ & $1.3 \times 10^{-10}$ & $3.3 \times 10^{-6}$ & $1.1 \times 10^{-12}$ & $1.5 \times 10^{.5}$ & $5.1 \times 10^{-5}$ & $6.9 \times 10^{-5}$ \\
\hline $\begin{array}{l}\text { Eubank Gate } \\
\text { Area }\end{array}$ & $3.1 \times 10^{.9}$ & $3.8 \times 10^{-9}$ & $6.8 \times 10^{-8}$ & $2.2 \times 10^{-10}$ & $4.9 \times 10^{-6}$ & $1.1 \times 10^{-12}$ & $5.5 \times 10^{-5}$ & $3.5 \times 10^{-5}$ & $9.5 \times 10^{-5}$ \\
\hline $\begin{array}{l}\text { Northeast } \\
\text { Resident }\end{array}$ & $2.7 \times 10^{-10}$ & $2.2 \times 10^{-10}$ & $1.1 \times 10^{-10}$ & $9.4 \times 10^{-12}$ & $2.2 \times 10^{-6}$ & $4.7 \times 10^{-13}$ & $9.3 \times 10^{-7}$ & $1.5 \times 10^{-5}$ & $1.8 \times 10^{-5}$ \\
\hline East Resident & $9.6 \times 10^{-11}$ & $6.5 \times 10^{-11}$ & $1.2 \times 10^{-11}$ & $3.2 \times 10^{-12}$ & $9.8 \times 10^{-7}$ & $1.6 \times 10^{-13}$ & $3.6 \times 10^{-8}$ & $3.6 \times 10^{-6}$ & $4.6 \times 10^{-6}$ \\
\hline Isleta Mine & $1.4 \times 10^{-10}$ & $9.8 \times 10^{-11}$ & $1.6 \times 10^{-11}$ & $4.6 \times 10^{-12}$ & $1.4 \times 10^{-6}$ & $2.0 \times 10^{-13}$ & $3.0 \times 10^{-8}$ & $4.2 \times 10^{-6}$ & $5.6 \times 10^{-6}$ \\
\hline West Resident & $4.3 \times 10^{-10}$ & $3.6 \times 10^{-10}$ & $7.4 \times 10^{.11}$ & $1.6 \times 10^{-11}$ & $3.9 \times 10^{-6}$ & $3.0 \times 10^{-13}$ & $2.3 \times 10^{-7}$ & $1.6 \times 10^{-5}$ & $2.0 \times 10^{-5}$ \\
\hline $\begin{array}{l}\text { U.S. Geological } \\
\text { Survey }\end{array}$ & $1.7 \times 10^{-10}$ & $1.2 \times 10^{-10}$ & $3.2 \times 10^{-11}$ & $7.5 \times 10^{-12}$ & $2.0 \times 10^{-6}$ & $3.9 \times 10^{-13}$ & $1.6 \times 10^{-7}$ & $1.2 \times 10^{-5}$ & $1.4 \times 10^{-5}$ \\
\hline $\begin{array}{l}\text { Four Hills } \\
\text { Resident }\end{array}$ & $8.7 \times 10^{-10}$ & $8.3 \times 10^{-10}$ & $2.2 \times 10^{-9}$ & $4.1 \times 10^{-11}$ & $4.6 \times 10^{-6}$ & $1.2 \times 10^{-12}$ & $1.3 \times 10^{-5}$ & $3.8 \times 10^{-5}$ & $5.7 \times 10^{-5}$ \\
\hline
\end{tabular}


Table 5-9. Annual Effective Dose Equivalent (mrem/yr) to Kirtland Air Force Base (KAFB) On-Site Receptors

\begin{tabular}{|c|c|c|c|c|c|c|c|c|c|}
\hline Receptor & $\begin{array}{c}\text { Bldg. 891, TOF } \\
\text { Laboratory and } \\
\text { Metal Tritide } \\
\text { Laboratory }\end{array}$ & $\begin{array}{l}\text { Bldg. } 805 \text {, } \\
\text { Radiation } \\
\text { Laboratory }\end{array}$ & $\begin{array}{l}\text { Bldg. 884, } \\
\text { Tandem }\end{array}$ & $\begin{array}{l}\text { Bldg. 869, } \\
\text { Calibration } \\
\text { Laboratory }\end{array}$ & $\begin{array}{c}\text { Mixed } \\
\text { Waste } \\
\text { Landfill } \\
\end{array}$ & $\begin{array}{c}\text { Bldg. } 6600, \\
\text { Chemical } \\
\text { Processing } \\
\text { Laboratory }\end{array}$ & $\begin{array}{l}\text { Bldg. } \\
\text { 970/983, } \\
\text { HERMES-III } \\
\text { and PBFA-II } \\
\end{array}$ & $\begin{array}{l}\text { Bldg. } 6588, \\
\text { ACRR and } \\
\text { SPR }\end{array}$ & Total Dose \\
\hline $\begin{array}{l}\text { Kirtland } \\
\text { Underground } \\
\text { Munitions Storage } \\
\text { Complex } \\
\text { (KUMSC) }\end{array}$ & $1.9 \times 10^{-10}$ & $8.8 \times 10^{.10}$ & $1.2 \times 10^{-9}$ & $7.7 \times 10^{-12}$ & $5.0 \times 10^{-6}$ & $1.3 \times 10^{-11}$ & $2.9 \times 10^{-5}$ & $5.0 \times 10^{-4}$ & $5.3 \times 10^{-4}$ \\
\hline KAFB Landfill & $3.7 \times 10^{-10}$ & $1.6 \times 10^{-9}$ & $2.0 \times 10^{-8}$ & $1.6 \times 10^{-11}$ & $1.1 \times 10^{-6}$ & $1.8 \times 10^{-12}$ & $1.6 \times 10^{-4}$ & $6.0 \times 10^{-5}$ & $2.2 \times 10^{-4}$ \\
\hline $\begin{array}{l}\text { Raytheon/Defense } \\
\text { Nuclear Agency } \\
\text { (DNA) }\end{array}$ & $4.5 \times 10^{-10}$ & $4.5 \times 10^{-9}$ & $4.3 \times 10^{-8}$ & $4.4 \times 10^{-11}$ & $9.9 \times 10^{-7}$ & $1.8 \times 10^{-12}$ & $3.8 \times 10^{-4}$ & $5.9 \times 10^{-5}$ & $4.4 \times 10^{-4}$ \\
\hline Golf Course Lobby & $1.7 \times 10^{-10}$ & $7.7 \times 10^{-10}$ & $1.8 \times 10^{-9}$ & $6.6 \times 10^{-12}$ & $2.0 \times 10^{-6}$ & $5.1 \times 10^{-12}$ & $2.5 \times 10^{-5}$ & $1.9 \times 10^{-4}$ & $2.2 \times 10^{-4}$ \\
\hline $\begin{array}{l}\text { Golf Course } \\
\text { Maintenance }\end{array}$ & $1.9 \times 10^{-10}$ & $9.1 \times 10^{-10}$ & $2.7 \times 10^{-9}$ & $8.9 \times 10^{-12}$ & $1.7 \times 10^{-6}$ & $3.8 \times 10^{-12}$ & $8.2 \times 10^{.5}$ & $1.3 \times 10^{-4}$ & $2.1 \times 10^{-4}$ \\
\hline Riding Club & $1.2 \times 10^{.10}$ & $5.0 \times 10^{-10}$ & $7.9 \times 10^{-10}$ & $4.7 \times 10^{-12}$ & $2.0 \times 10^{-6}$ & $4.9 \times 10^{-12}$ & $1.5 \times 10^{-5}$ & $2.3 \times 10^{-4}$ & $2.5 \times 10^{-4}$ \\
\hline $\begin{array}{l}\text { Civil Engineering } \\
\text { Research Center }\end{array}$ & $4.8 \times 10^{-11}$ & $1.7 \times 10^{-10}$ & $1.1 \times 10^{-10}$ & $1.6 \times 10^{-12}$ & $6.3 \times 10^{-3}$ & $8.9 \times 10^{-13}$ & $8.6 \times 10^{-1}$ & $3.3 \times 10^{-5}$ & $3.4 \times 10^{-5}$ \\
\hline Lovelace & $4.3 \times 10^{-11}$ & $1.6 \times 10^{-10}$ & $8.2 \times 10^{-11}$ & $1.4 \times 10^{-12}$ & $6.8 \times 10^{-7}$ & $8.7 \times 10^{-13}$ & $6.0 \times 10^{-7}$ & $3.4 \times 10^{-5}$ & $3.5 \times 10^{-5}$ \\
\hline Manzano Offices & $8.3 \times 10^{-11}$ & $3.2 \times 10^{.10}$ & $3.4 \times 10^{-10}$ & $2.9 \times 10^{-12}$ & $1.2 \times 10^{-6}$ & $2.1 \times 10^{-12}$ & $2.9 \times 10^{-6}$ & $9.7 \times 10^{-5}$ & $1.0 \times 10^{-4}$ \\
\hline Credit Unions & $1.2 \times 10^{-9}$ & $8.4 \times 10^{-7}$ & $3.2 \times 10^{-7}$ & $2.4 \times 10^{-10}$ & $6.9 \times 10^{-7}$ & $9.7 \times 10^{-13}$ & $5.9 \times 10^{-5}$ & $3.7 \times 10^{-5}$ & $9.8 \times 10^{-5}$ \\
\hline $\begin{array}{l}\text { Pershing Park } \\
\text { Housing }\end{array}$ & $4.8 \times 10^{-9}$ & $1.2 \times 10^{.8}$ & $2.2 \times 10^{-8}$ & $3.0 \times 10^{-10}$ & $3.4 \times 10^{-6}$ & $9.7 \times 10^{-13}$ & $2.1 \times 10^{-3}$ & $2.7 \times 10^{-5}$ & $5.1 \times 10^{-5}$ \\
\hline Loop Housing & $8.3 \times 10^{-9}$ & $4.4 \times 10^{-8}$ & $1.6 \times 10^{-7}$ & $8.7 \times 10^{-10}$ & $4.4 \times 10^{-6}$ & $9.6 \times 10^{-13}$ & $4.0 \times 10^{-3}$ & $3.0 \times 10^{-5}$ & $7.5 \times 10^{-5}$ \\
\hline Zia Park Housing & $7.2 \times 10^{-9}$ & $2.3 \times 10^{-8}$ & $7.1 \times 10^{-8}$ & $4.9 \times 10^{-10}$ & $5.0 \times 10^{-6}$ & $1.3 \times 10^{-12}$ & $5.3 \times 10^{-5}$ & $4.0 \times 10^{-5}$ & $9.8 \times 10^{-5}$ \\
\hline Maxwell Housing & $2.1 \times 10^{-9}$ & $2.1 \times 10^{-9}$ & $2.3 \times 10^{-9}$ & $7.7 \times 10^{-11}$ & $4.0 \times 10^{-6}$ & $1.3 \times 10^{-12}$ & $7.4 \times 10^{.5}$ & $3.8 \times 10^{-5}$ & $4.9 \times 10^{-5}$ \\
\hline
\end{tabular}

Note: $\mathrm{mrem} / \mathrm{yr}=$ millirem per year; TOF $=$ Time of Flight; HERMES-III = High-Energy Radiation Megavolt Electron Source (Accelerator) III; PBFA-II = Particle Beam Fusion AcceleratorII; ACRR Annular Core Research Reactor; SPR = Sandia Pulsed Reactor. 


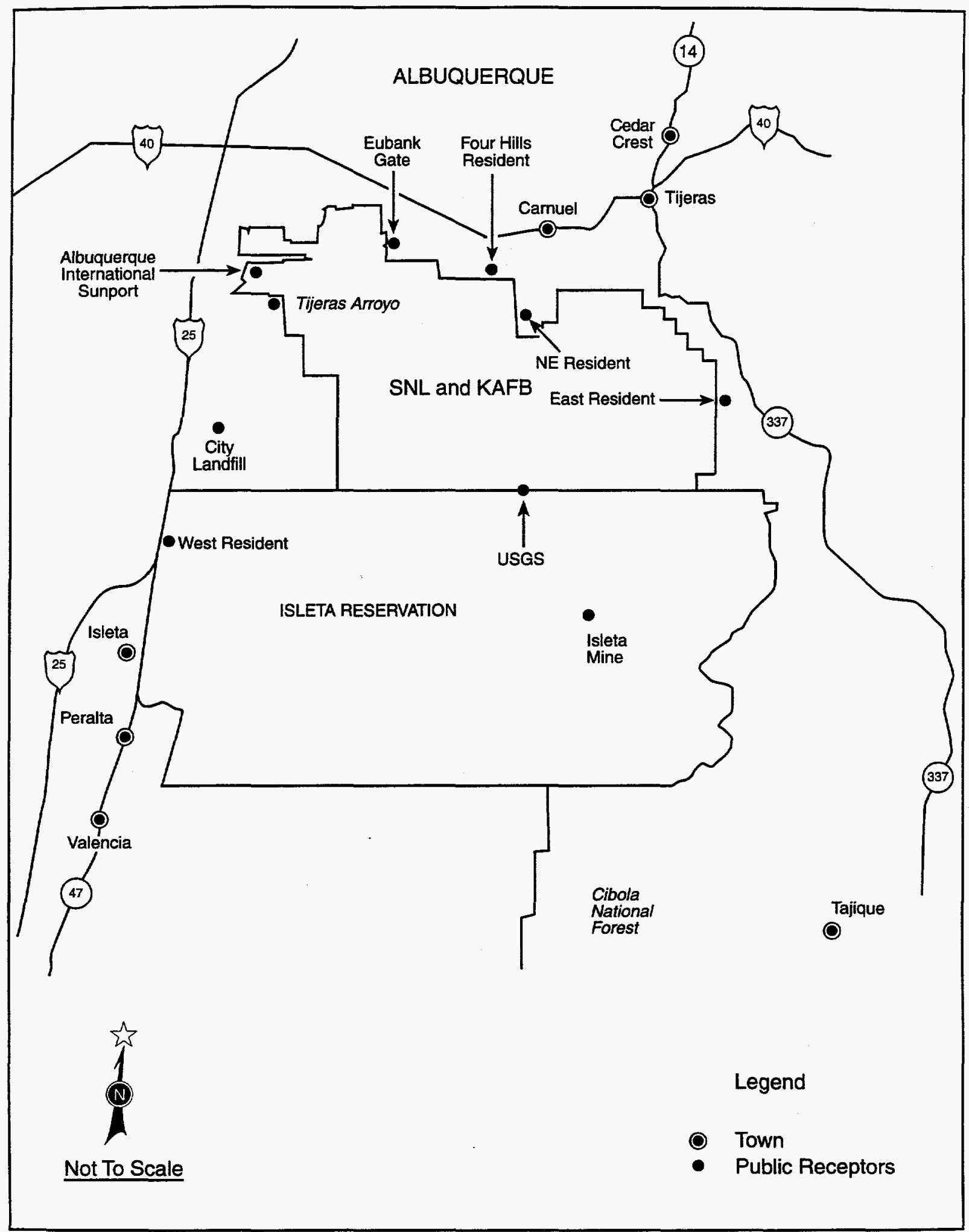

Figure 5-7. Off-Site and Boundary Receptor Locations Around SNL/NM 


\subsubsection{Population Dose for the 50-Mile Radius}

A population dose was calculated for the 50-mi radius surrounding SNL/NM using a single, common grid analysis for all SNL/NM sources. Because the analysis area is large, the relatively small distances between sources have a minimal impact on the resulting population dose. As stated earlier, the CAP88-PC computer code calculated exposure estimates using demographic data based on the 1990 population census and 1988 agricultural census: 571,677 people, 32,335 beef cattle, 7,290 dairy cattle, and $2.4 \times 10^{8} \mathrm{~m}^{2}$ of food crops from the nine counties included in the study area (EPA 1991; DOC 1992; LATA 1991). The population dose from 1994 SNL/NM operations was calculated to be 0.012 person-rem EDE for the regional population. The population dose primarily results from exposure to $\mathrm{Ar}-41, \mathrm{~N}-13$, and $\mathrm{H}-3$.

\subsection{SUMMARY OF THE 1994 ON-SITE AND OFF-SITE DOSE IMPACTS}

During 1994, the NESHAP MEI was determined to be at the KUMSC site, approximately $1600 \mathrm{~m}$ northwest of SNL/NM TA-V. The maximum EDE at this on-site location was calculated to be $5.3 \times 10^{-4}$ millirem (mrem). The maximum off-site EDE was calculated to be $1.5 \times 10^{-4}$ mrem at the Tijeras Arroyo location which is approximately $5500 \mathrm{~m}$ southwest of TA-I and $5000 \mathrm{~m}$ west-northwest of TA-V. A population dose to the public was calculated to be 0.012 person-rem to the 571,677 people living within a $50-$ mi radius of SNL/NM. The population dose to the 6477 residents of KAFB was calculated to be $5.1 \times 10^{-4}$ person-rem. Table 5-10 summarizes the dose impacts.

\subsection{AIR QUALITY MANAGEMENT}

\subsubsection{Air Quality Regulations}

Air quality for SNL/NM is regulated by the Albuquerque/Bernalillo County Air Quality Control Board (ABC/AQCB) Air Quality Control Regulations (AQCRs). These include the following:

- Ambient Air Quality Standard (regulates arsenic [As], copper [Cu], zinc [Zn], beryllium [Be], carbon monoxide [CO], hydrogen sulfide $\left[\mathrm{H}_{2} \mathrm{~S}\right]$, lead, nitrogen dioxide $\left(\mathrm{NO}_{2}\right)$, sulfur dioxide $\left(\mathrm{SO}_{2}\right)$, total suspended particulates [TSP], hydrocarbons $[\mathrm{HC}]$, photochemical oxidants, soiling index, and total reduced sulfur)

- AQCR \#3, Open Burning

- AQCR \#5, Visible Air Contaminants

- AQCR \#8, Airborne Particulate Matter (PM)

- AQCR \#11, Volatile Organic Compounds (VOCs) 
Table 5-10. Summary of On-Site and Off-Site Impacts in Comparison to the National Emission Standards for Hazardous Air Pollutants (NESHAP) and to Natural Background Radiation

\begin{tabular}{lccc} 
Parameters & $\begin{array}{c}\text { 1994 SNL/NM } \\
\text { Calculated Dose }\end{array}$ & NESHAP Standard & $\begin{array}{c}\text { Natural Background } \\
\text { Radiation in the } \\
\text { Albuquerque Area }\end{array}$ \\
\hline $\begin{array}{l}\text { On-Site Maximum } \\
\text { Effective Dose }\end{array}$ & $5.3 \times 10^{-4}$ & 10 & $95^{*}$ \\
$\begin{array}{l}\text { Equivalent } \\
\text { (mrem/yr) }\end{array}$ & & & \\
$\begin{array}{l}\text { Off-Site Maximum } \\
\text { Effective Dose } \\
\begin{array}{l}\text { Equivalent } \\
\text { (mrem/yr) }\end{array}\end{array}$ & $1.5 \times 10^{-4}$ & 10 & $95^{*}$ \\
$\begin{array}{l}\text { Annual Population } \\
\text { Dose } \\
\text { (person-rem) }\end{array}$ & 0.012 & & $>57,000$ \\
$\begin{array}{l}\text { Annual Kirtland Air } \\
\text { Force Base Popula- } \\
\text { tion Dose } \\
\text { rem) }\end{array}$ & $5.1 \times 10^{-4}$ & $--^{\dagger}$ & \\
\end{tabular}

Note: $\mathrm{mrem} / \mathrm{yr}=$ millirem per year; person-rem $=$ radiation dose to population (also man-rem).

* Based on the average community thermoluminescent dosimeter (TLD) values (doses from external penetrating radiation).

+ Not measured.

${ }^{\ddagger}$ Dose for the population in 50-mi radius surrounding SNL/NM

${ }^{\mp}$ Dose for the KAFB population of 6,477 residents.

- AQCRs \#15-18, Process Equipment Emissions (nitrogen oxides $\left[\mathrm{NO}_{\mathrm{x}}\right], \mathrm{SO}_{2}$, and particulates) for Oil- and Gas-Burning Equipment

- AQCR \#19, Breakdown, Abnormal Operating Conditions, or Scheduled Maintenance

- AQCR \#20, Authority-to-Construct Permit

- AQCR \#21, Permit Fees

- AQCR \#22, Registration of Air Contaminant Sources 
- AQCR \#23, Source Surveillance

- AQCR \#24, Variance Procedure

- AQCR \#28, Motor Vehicle Inspection

- AQCR \#29, Prevention of Significant Deterioration

- AQCR \#30, New Source Performance Standards

- AQCR \#31, NESHAP

- AQCR \#32, Construction Permits - Nonattainment Areas

- AQCR \#37, Stratospheric Ozone Protection

- AQCR \#41, Operating Permits

- AQCR \#42, Transportation Conformity

- AQCR \#43, General Conformity

The Air Pollution Control Division of the City of Albuquerque Environmental Health Department has established several ambient-air sampling stations throughout the city, including areas near SNL/NM, to monitor TSP, ozone $\left(\mathrm{O}_{3}\right)$, particulate matter (diameter equal to or less than 10 microns $\left.\left[\mathrm{PM}_{10}\right]\right), \mathrm{CO}$, and $\mathrm{NO}_{\mathrm{x}}$. The sampling results were published periodically in local newspapers. No exceedances of the measured pollutants were observed at the stations near SNL/NM in 1994.

\subsubsection{Airborne Emissions and Permits}

Several sources at SNL/NM emit air pollutants that are regulated by the AQCRs. The emissions from these sources are described below.

- Open Burning (AQCR \#3) - The open-burning regulation includes activities such as the disposal of explosives by burning to avoid the hazards of transport or handling, aboveground detonation of more than 20 pounds (lb) of explosives, single-event research and development activities of 2000 gallons (gal.) of liquid fuel, and ignition of rocket motors containing more than $20 \mathrm{lb}$ of explosives or more than $4000 \mathrm{lb}$ of fuel. In addition, the city divides the permit basis into two categories: multiple-event and single-event. The single-event permit was designed to regulate activities with significant impact. 
Open-burn permits were obtained from the City of Albuquerque for each scheduled regulated burn or test according to the requirement of AQCR \#3. A total of 15 multiple- and single-event open-burn permits were issued or extended to SNL/NM during 1994 (see Table 2-2).

- Airborne Particulate Matter (AOCR \#8) - Before disturbing, moving, placing, or removing the soil of any area larger than $3 / 4$ acre, SNL/NM or its contractor applies for a topsoil disturbance permit and implements a plan for controlling dust emissions generated by construction activities in accordance with the requirements of AQCR \#8. These mitigation measures could include watering, phasing construction, rescheduling construction during windy periods, limiting vehicle access and vehicle speed, or using dust palliatives where watering is ineffective. A permit is also required before demolishing any building containing over 75,000 cubic feet of space.

- Volatile Organic Compounds (AOCR \#11) - This regulation requires all underground storage tanks with a capacity of 3000 gal. or more of gasoline to have Stage-I recovery control for VOCs. Only one 12,000 -gal. tank in TA-I requires Stage-I recovery and it has been in compliance with the requirements. The 1992 Transportation Service Division Procedures Manual was revised to incorporate the requirement of Stage-I recovery in the procedure for receiving fuel (Hindl et al. 1992). Compliance has been demonstrated by the certification stamp and signature of the receiving personnel on the delivery receipt for each shipment and unloading of fuel.

- Oil-and Gas-Burning Equipment (AOCRs \#15-\#18) - SNL/NM currently has five steam boilers with capacities that range from 94 to 235 million British thermal units per hour (MBtu/hr). Because these boilers were grandfathered sources, no authority-to-construct permits were required.

- Authority-to-Construct Permits (AQCR \#20) - The four standby diesel generators in Building 862 are permitted by the City of Albuquerque. Other emergency generators on-site will be reviewed for permits or registrations.

\subsubsection{Criteria Pollutants Inventory}

During 1994, SNL/NM operated five steam boilers. The steam plant consumed a total of almost 828 million standard cubic feet (scf) of natural gas and 5700 gal. of fuel oil, and produced 522 million $\mathrm{lb}$ of steam. Based on the operation data provided by Plant Engineering, emissions of $\mathrm{NO}_{\mathrm{x}}, \mathrm{CO}, \mathrm{SO}_{2}, \mathrm{HC}$, and TSP were calculated for each boiler. Table 5-11 summarizes the calculated results. Published emission factors in EPA AP-42 for the criteria pollutants were used in the annual emission calculations (EPA 1993). 
Table 5-11. 1994 Criteria Pollutant Inventory

\begin{tabular}{|c|c|c|c|c|c|c|}
\hline \multirow{2}{*}{$\begin{array}{l}\text { Pollutants/ } \\
\text { Source }\end{array}$} & \multicolumn{5}{|c|}{ Steam Generators* } & \multirow{2}{*}{$\begin{array}{c}\text { Total } \\
\text { Emissions }\end{array}$} \\
\hline & No. 1 & No. 2 & No. 3 & No. 5 & No. 6 & \\
\hline Nitrogen Oxides $\left(\mathrm{NO}_{\mathrm{x}}\right)$ & 9.32 & 9.26 & 8.54 & 73.17 & 47.95 & 148.24 \\
\hline $\begin{array}{l}\text { Carbon } \\
\text { Monoxide (CO) }\end{array}$ & 2.33 & 2.32 & 2.13 & 5.32 & 3.49 & 15.59 \\
\hline $\begin{array}{l}\text { Total Suspended } \\
\text { Particulates (TSP) }\end{array}$ & 0.91 & 0.91 & 0.84 & 0.66 & 0.44 & 3.75 \\
\hline Sulfur Dioxide $\left(\mathrm{SO}_{2}\right)$ & 0.04 & 0.04 & 0.04 & 0.13 & 0.09 & 0.34 \\
\hline $\begin{array}{l}\text { Total Organic Carbon } \\
\text { (TOC) }\end{array}$ & 0.19 & 0.18 & 0.17 & 0.19 & 0.12 & 0.85 \\
\hline \multicolumn{7}{|c|}{ "Number 4 boiler was retired and no emissions were generated. Amounts are } \\
\hline
\end{tabular}

SNL/NM also operates an emergency generator plant (Building 862) with four 600-kilowatt (kW) standby generators. Table 5-12 summarizes the emissions from the emergency generators based on EPA AP-42 published emission factors (EPA 1993) and 1994 operation data.

\subsubsection{Inventory and Assessment of Hazardous Air Emissions}

Formed in October 1993, the Hazardous Chemical Usage Inventory team developed a streamlined process to collect laboratory-wide chemical usage information. The team annually reviews the process to perform the Hazardous Chemical Usage Inventory. Line organizations are then polled to verify computer-generated usage reports. Table 5-13 presents the results of the 1994 inventory. 
Table 5-12. 1994 Emergency Generator Emissions Estimates

\begin{tabular}{|c|c|c|c|c|c|}
\hline \multirow{2}{*}{$\begin{array}{l}\text { Pollutants/ } \\
\text { Source }\end{array}$} & \multicolumn{4}{|c|}{ Electrical Generators" (600-kilowatt) } & \multirow{2}{*}{$\begin{array}{c}\text { Total } \\
\text { Emissions }\end{array}$} \\
\hline & No. 1 & No. 2 & No. 3 & No. 4 & \\
\hline $\begin{array}{l}1994 \text { Hours } \\
\text { of Operation }\end{array}$ & $28.7 \mathrm{hr}$ & $22.9 \mathrm{hr}$ & $25.3 \mathrm{hr}$ & $26.5 \mathrm{hr}$ & $103.4 \mathrm{hr}$ \\
\hline Fuel Usage (gallons) & 1,294 & 1,039 & 1,144 & 1,198 & 4,679 \\
\hline $\begin{array}{l}\text { Nitrogen Oxides } \\
\left(\mathrm{NO}_{x}\right)^{\dagger}\end{array}$ & 0.171 & 0.137 & 0.151 & 0.158 & 0.617 \\
\hline $\begin{array}{l}\text { Carbon Monoxide } \\
(\mathrm{CO})^{\dagger}\end{array}$ & 0.0065 & 0.0052 & 0.0057 & 0.0060 & 0.023 \\
\hline $\begin{array}{l}\text { Total Suspended } \\
\text { Particulates (TSP) }\end{array}$ & 0.0062 & 0.0050 & 0.0055 & 0.0057 & 0.022 \\
\hline Sulfur Oxides $\left(\mathrm{SO}_{\mathrm{x}}\right)^{\ddagger}$ & 0.0364 & 0.0292 & 0.0321 & 0.0336 & 0.131 \\
\hline Hydrocarbons $(\mathrm{HC})^{\ddagger}$ & 0.0286 & 0.0229 & 0.0252 & 0.0264 & 0.103 \\
\hline \multicolumn{6}{|c|}{$\begin{array}{l}\text { "Emissions are in tons per year. } \\
\text { 'Based on Kramer \& Associates performance tests (Kramer \& Associates 1988a, 1988b). } \\
\text { 'Based on AP-42, Emission Factors for Diesel Industrial Engines } \\
\text { (EPA 1993). }\end{array}$} \\
\hline
\end{tabular}


Table 5-13. Summary of Significant Laboratory-Wide Chemical Usage

Chemical

Chemical Abstract

System (CAS) Number

Usage (lb)

Sulfuric acid

Hydrogen chloride

Toluene

Xylene

Cyclohexane

Acetone

Isopropyl alcohol

1,1,1-Trichloroethane (methyl chloroform)

Nitric acid

Methanol (methyl alcohol)

Ethylene glycol

Freon 113 (chlorofluorocarbon [CFC]-113)

Hydrogen fluoride

Chlorodifluoromethane (HCFC-22)
7664-93-9

7647-01-0

108-88-3

1330-20-7

110-82-7

$67-64-1$

67-63-0

$71-55-6$

$7697-37-2$

67-56-1

107-21-1

76-13-1

7664-39-3

75-45-6
31,156

24,587

12,703

12,937

5,971

6,027

4,461

2,021

3,037

2,770

11,246

1,021

1,994

3,912 


\subsection{WATER MONITORING PROGRAMS}

\subsection{WASTE-WATER PROGRAMS}

\subsubsection{Discharges to Publicly Owned Treatment Works}

Sandia National Laboratories/New Mexico (SNL/NM) contains over 15 miles (mi) of sewer lines interconnected with those of Kirtland Air Force Base (KAFB). During 1994, SNL/NM had two categorical pretreatment operations and four general waste-water streams discharging to the City of Albuquerque publicly owned treatment works (POTW). Table 2-2 includes a list of waste-water discharge permits.

Discharges by SNL/NM to the POTW are regulated by the City of Albuquerque Public Works Department, Liquid Waste Division, under the authority of the City's Sewer Use and Wastewater Control Ordinance. The City's NPDES permit is issued by the EPA in accordance with the Clean Water Act (CWA) as amended.

To comply with EPA regulations, the City of Albuquerque has implemented an industrial waste-water pretreatment program. This program requires SNL/NM to obtain permits for waste-water discharges to the City's POTW. These permits specify the required quality of discharges and the frequency of reporting the monitoring results.

In June 1994, SNL/NM activated the Technical Area V (TA-V) Liquid Effluent Control System (LECS) to retain process waste water for radiological screening prior to disposal into the sanitary sewer. The system segregates the process effluent from the routine sanitary effluent generated in TA-V by directing the sanitary effluent flow to the sanitary sewer system and collecting the process effluent in the LECS for analysis prior to discharge. The sanitary effluent and any discharges from the LECS flow through monitoring station WW011 (Permit Number 2069K). Before sampling, influent flow is switched to one of two other tanks to isolate the active tank's sample volume. Grab samples are collected and delivered to radiological laboratories for screening analysis. Samples are analyzed for gross-alpha particle activities, gross-beta particle activities, tritium $(\mathrm{H}-3)$, and gamma emitters. Duplicate samples are collected periodically and shipped to a contracted laboratory for independent analysis. The sampling results indicate the waste-water discharges from the LECs are below regulatory limits set by the U.S. Nuclear Regulatory Commission (USNRC), the U.S. Department of Energy (DOE), and the State of New Mexico.

SNL/NM's policy prohibits the disposal of radiological material above regulatory levels into the sanitary sewer system. Although performing radiological analyses for the permitted outfall locations is not required by the permits, analyses results are included to satisfy reporting requirements established by the City of Albuquerque's Sewer Use and Wastewater Control Ordinance, Section 8-9-44.H, which states that all analyses performed in accordance with prescribed procedures established by the EPA under provisions contained in 40 CFR 136 shall be reported. Results of radiological sampling are contained in the Wastewater Monitoring Program Quarterly and Semiannual Reports for 1994 (IT 1994b and 1995). 
Table 6-1 describes the waste-water sampling locations and summarizes sampling location characteristics (see also Figure 6-1). The sampling procedures, permit limits for individual sampling stations, dates of sample collection and sample frequency, analytical methods, and quality control/quality assurance criteria are documented in the SNL/NM Wastewater Sampling Plan (Booher 1992). Complete documentation concerning the waste-water sampling program can be found in the Wastewater Monitoring Program Quarterly and Semiannual Reports for 1994 (IT 1994b and 1995).

\subsubsection{Summary of Monitoring Results}

This section describes each of the waste-water discharge permits and addresses those instances in which the monitoring results did not comply with the permit limits documented in the Wastewater Monitoring Program Quarterly and Semiannual Reports for 1994 (IT 1994b and 1995). Table 6-2 summarizes the sample concentration violations and permit limits.

Permit 2069A-2: This is a general permit for waste-water discharges from a portion of TA-I.

- Analytical Results - Analytical results from laboratory analyses show all analyte concentrations to be less than permitted requirements with the exception of an oil and grease concentration collected on November 15, 1994. This concentration exceeded the permit limit but caused no impact on the operation of the POTW. Table 6-2 summarizes the sample concentration and permit limit.

- Hydrogen-Ion Concentration (pH) - No $\mathrm{pH}$ excursion of waste-water discharges above the permitted $\mathrm{pH}$ limits occurred for greater than 1 hour (hr) during 1994. Dates of $\mathrm{pH}$ excursions for $1 \mathrm{hr}$ or less, total time the waste-water $\mathrm{pH}$ was out of permit limits, dates of sample collection, and sampling frequencies for each month for Permit 2069A-2 are contained in the Wastewater Monitoring Program Quarterly and Semiannual Reports for 1994 (IT 1994b and 1995).

Permit 2069D-3: Activities at this permitted location were terminated and the City of Albuquerque deactivated this permit.

Permit 2069F-2: This is a general permit for waste-water discharges from a portion of TA-I and some KAFB facilities.

- Analytical Results - Analytical results from laboratory analyses show all analyte concentrations to be less than permitted requirements.

- $\mathrm{pH}-$ No $\mathrm{pH}$ excursions of waste-water discharges above the permitted $\mathrm{pH}$ limits occurred for greater than $1 \mathrm{hr}$ during 1994. Dates of $\mathrm{pH}$ excursions for $1 \mathrm{hr}$ or less, total time the waste-water $\mathrm{pH}$ was out of permit limits, dates of sample collection, and sampling frequencies for each month for Permit 2069F-2 are contained in the Wastewater Monitoring Program Quarterly and Semiannual Reports for 1994 (IT 1994b and 1995). 
Table 6-1. SNL/NM Waste-Water Discharge Permits, Sampling Locations, and Station Characteristics

\begin{tabular}{|c|c|c|c|c|c|c|}
\hline $\begin{array}{l}\text { Permit } \\
\text { Number }\end{array}$ & $\begin{array}{c}\text { Station } \\
\text { Manhole } \\
\text { Number }\end{array}$ & Location & $\begin{array}{l}\text { Average } \\
\text { Flow } \\
\text { (gpd) }\end{array}$ & $\begin{array}{l}\text { Waste } \\
\text { Stream } \\
\text { Process }\end{array}$ & $\begin{array}{l}\text { Issuing } \\
\text { Agency }\end{array}$ & Flumes \\
\hline 2069A-2 & $\begin{array}{l}\text { WW001 } \\
\text { Tijeras } \\
\text { Arroyo }\end{array}$ & South of TA-IV & 91,721 & General & $\begin{array}{l}\text { City of Albuquerque, } \\
\text { I.C. } 7391\end{array}$ & $\begin{array}{l}\text { 3-inch } \\
\text { Parshall }\end{array}$ \\
\hline $2069 \mathrm{~F}-2$ & WW006 & $\begin{array}{l}\text { East of KAFB } \\
\text { Sanitary Lagoons }\end{array}$ & 385,747 & General & $\begin{array}{l}\text { City of Albuquerque, } \\
\text { I.C. } 3674,3694,9711\end{array}$ & $\begin{array}{l}\text { 6-inch } \\
\text { Parshall }\end{array}$ \\
\hline 2069G-2 & $\begin{array}{l}\text { WW007 } \\
\text { Bldg. 858 } \\
\text { Basement }\end{array}$ & TA-I & 144,722 & $\begin{array}{l}\text { Microelectronics } \\
\text { Development } \\
\text { Laboratory }\end{array}$ & $\begin{array}{l}\text { City of Albuquerque, } \\
40 \text { CFR } 469 . \text { A }\end{array}$ & $\begin{array}{l}45 \circ \text { V-Notch } \\
\text { Weir }\end{array}$ \\
\hline $2069 \mathrm{~K}$ & WW011 & $\begin{array}{l}\text { North of TA-III } \\
\text { (includes TA-III, } \\
\text { TA-V, and Coyote } \\
\text { Test Area sewer } \\
\text { lines) }\end{array}$ & 54,798 & General & $\begin{array}{l}\text { City of Albuquerque, } \\
\text { I.C. } 3674,3679,9711\end{array}$ & $\begin{array}{l}\text { 6-inch } \\
\text { Parshall }\end{array}$ \\
\hline
\end{tabular}




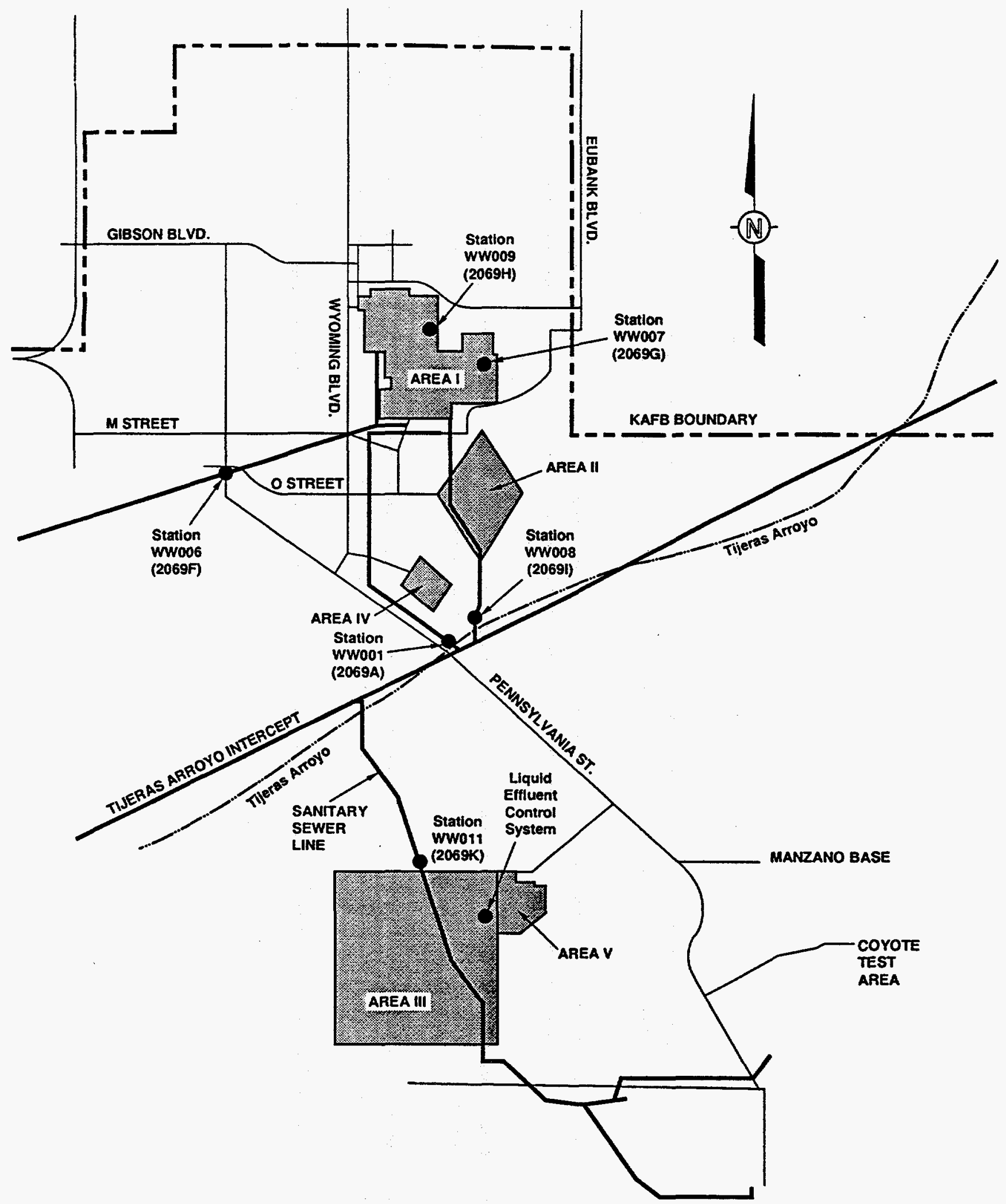

Figure 6-1. SNL/NM Waste-Water Monitoring Station Locations 
Table 6-2. Summary of Concentration Violations

Permit

Number

2069A-2

$2069 \mathrm{H}-2$
Sample Date

11/15/94,

24-hr Composite

(oil and grease)

03/29/94,

24-hr Composite

(oil and grease)

$11 / 15 / 94$,

24-hr Composite

(nickel)

$12 / 06 / 94$,

24-hr Composite

(lead)

$12 / 07 / 94$,

24-hr Composite

(lead)
Concentration

(mg/L)

140

75

110

75

30

47

0.72

0.24

1.0

0.24

Note: $\mathrm{mg} / \mathrm{L}=$ milligrams per liter.

Permit 2069G-2: This permit covers discharges from categorical, regulated semiconductor production activity in Building 858 of TA-I.

- Analytical Results - Analytical results from laboratory analyses show all analyte concentrations to be less than permitted requirements.

- $\mathrm{pH}-$ One $\mathrm{pH}$ excursion of waste-water discharge above the permitted $\mathrm{pH}$ limits occurred on January 18,1994 , for 70 minutes (min), with the maximum $\mathrm{pH}$ level reaching 12.4. The cause of the excursion was traced to a malfunctioning control valve on the acid waste neutralization (AWN) system. The valve was repaired and the system brought back into control. Dates of $\mathrm{pH}$ excursions for $1 \mathrm{hr}$ or less, total time the waste-water $\mathrm{pH}$ was out of permit limits, dates of sample collection, and sampling frequencies for each month for Permit 2069G-2 are contained in the 
Wastewater Monitoring Program Quarterly and Semiannual Reports for 1994 (IT 1994b and 1995).

Permit 2069H-2: This permit covers discharges from the categorical, regulated, printed circuit activity at the Advanced Manufacturing Processes Laboratory (AMPL) formerly called the Process Development Laboratory (PDL) located in Building 878 of TA-I.

- Analytical Results - Analytical laboratory analyses show all analyte concentrations to be less than permitted requirements with the following exceptions: high oil and grease concentration from a sample collected on March 29, 1994; a nickel concentration from a sample collected on November 15, 1994; and a lead concentration from samples collected on December 6 and 7, 1994. These violations exceeded the permit limit but caused no impact on the operation of the POTW. Table 6-2 summarizes the sample concentrations and permit limits. Corrective actions are documented in the Wastewater Monitoring Program Quarterly and Semiannual Reports for 1994 (IT 1994b and 1995).

- $\mathrm{pH}$ - One $\mathrm{pH}$ excursion of waste-water discharge above the permitted $\mathrm{pH}$ limits occurred on March 4, 1994, for 110 minutes, with the $\mathrm{pH}$ reaching a value of 3.5. Dates of $\mathrm{pH}$ excursions for $1 \mathrm{hr}$ or less, total time the waste-water $\mathrm{pH}$ was out of permit limits, dates of sample collection, and sampling frequencies for each month for Permit 2069H-2 are contained in the Wastewater Monitoring Program Quarterly and Semiannual Reports for 1994 (IT 1994b and 1995).

Permit 2069I: This is a general permit for waste-water discharges from TA-I, TA-II, and TAIV.

- Analytical Results - Analytical results from laboratory analyses show all analyte concentrations to be less than permitted requirements.

- $\mathrm{pH}-$ No $\mathrm{pH}$ excursion of waste-water discharges above the permitted $\mathrm{pH}$ limits occurred for greater than $1 \mathrm{hr}$ during 1994. Dates of $\mathrm{pH}$ excursions for $1 \mathrm{hr}$ or less, total time the waste-water $\mathrm{pH}$ was out of permit limits, dates of sample collection, and sampling frequencies for each month for Permit 2069I are contained in the Wastewater Monitoring Program Quarterly and Semiannual Reports for 1994 (IT 1994b and 1995).

Permit 2069K: This is a general permit for waste-water discharges from SNL/NM TA-III and TA-V.

- Analytical Results - Analytical results from laboratory analyses show all analyte concentrations to be less than permitted requirements.

- $\mathrm{pH}-$ No $\mathrm{pH}$ excursions of waste-water discharges above the permitted $\mathrm{pH}$ limits occurred for greater than $1 \mathrm{hr}$ during 1994. Dates of $\mathrm{pH}$ excursions for $1 \mathrm{hr}$ or less, 
total time the waste-water $\mathrm{pH}$ was out of permit limits, dates of sample collection, and sampling frequencies for each month for Permit $2069 \mathrm{~K}$ are contained in the Wastewater Monitoring Program Quarterly and Semiannual Reports for 1994 (IT 1994b and 1995).

\subsection{STORM WATER PROGRAM}

An amendment to the regulations implementing the CWA was promulgated on November 16, 1990, in the Federal Register. This amendment implements Section 402[p] of CWA, which was added by Section 405 of the Water Quality Act of 1987. The implementing regulations are published in 40 CFR 122-124. These enactments require EPA to regulate storm-water discharges associated with industrial activities. Industrial activities covered by these new regulations include Standard Industrial Classification (SIC) codes 20 through 39 . These SIC codes apply to several SNL/NM activities, including those at the Microelectronics Development Laboratory, the Process Development Laboratory, the Albuquerque Microelectronics Operation, and the plating shops in Building 840.

There are also requirements in 40 CFR 122 for permitting specific facility operations: salvage yards, vehicle maintenance yards, construction activities that disturb five or more acres, and hazardous waste treatment, storage, and disposal facilities. SNL/NM ongoing activities that fall under all these descriptions and others require SNL/NM to submit a National Pollutant Discharge Elimination System (NPDES) permit application for its storm-water discharges.

The industrial activities permit application was prepared and submitted to EPA, Region VI, on October 1, 1992. The permits for the construction of the Robotic Manufacturing Science and Engineering Laboratory, the Explosive Components Facility, and the Technology Support Facility are being covered by individual Notices of Intent to Discharge (NOIs) that have been submitted to EPA, Region VI, for each construction project. The permit applications and NOIs will be reviewed and approved by the EPA with State of New Mexico review and concurrence. No formal response has been received.

In 1994, two storm-water samples were taken and split with the New Mexico Environment Department. The first was taken on March 12, 1994, and the second was a composite from rainfall events on July 29 and August 3, 1994. The analytical results of one of the composite samples indicate the total dissolved solids and the specific conductance ratio were outside normal limits. No action will be taken on this until further sampling has been conducted to confirm the excursion and the EPA negotiates the permit to set contamination limits.

\subsection{SURFACE DISCHARGE PROGRAM}

Discharges to surface impoundments at SNL/NM are regulated under the authority of the New Mexico Water Quality Control Commission (NMWQCC) as implemented by the New Mexico Environment Department (NMED) Ground Water Bureau. Discharge Plan-530 (DP-530) was the only permitted discharge plan active at SNL/NM during 1994 (SNL 1993d and 1993e). 
DP-530 covers discharges to Lagoons I and II from pulsed-power operations in TA-IV. Water that accumulates in the secondary containment area for the Pulsed-Power Development Facilities oil storage tanks is discharged to two surface impoundments (Lagoons I and II) outside TA-IV. DP-530 was approved for these discharges in March 1988 and amended in December 1989, November 1992, and June 1993. The approved discharge plan, as amended, requires quarterly measurement of water levels and semiannual sampling and analysis. Waterlevel measurements were taken in March, June, September, and December 1994; both lagoons were sampled in March and September. The DP-530 semiannual reports document the sampling results (SNL 1993d and 1993e). No analytical parameters in either lagoon exceeded the NMWQCC maximum allowable standards. During 1994, the level in Lagoon I ranged from a high of 47 percent full in March to a low of 41 percent full in June. Lagoon II ranged from 71 percent full in March to 40 percent full in December.

DP-530 expired December 26, 1994. A renewal for DP-530 was submitted to NMED on September 26, 1994. NMED placed a public notice in a local newspaper on December 27, 1994, requesting comments on DP-530. The public comment period ended January 26, 1995, and the renewal is pending. 


\subsection{GROUNDWATER MONITORING}

This chapter describes groundwater monitoring activities conducted at Sandia National Laboratories/New Mexico (SNL/NM) during calendar year 1994 (CY94). Groundwater monitoring activities reported are those associated with the SNL/NM Environmental Restoration Project and the Groundwater Protection program. In addition, water level elevations in monitoring wells in the SNL/NM area were measured monthly to infer groundwater flow patterns in the region. Water level data are used to define long-term trends in groundwater quantity at Kirtland Air Force Base (KAFB).

Groundwater monitoring activities for CY94 were associated with the following:

- Groundwater Surveillance Task (also referred to as "basewide groundwater monitoring")

- Chemical Waste Landfill (CWL)

- $\quad$ Mixed Waste Landfill (MWL)

- Liquid Waste Disposal System (LWDS)

- Technical Area II (TA-II)

\subsection{REGULATORY REQUIREMENTS}

The Groundwater Protection Program is the implementation of U.S. Department of Energy (DOE) Order 5400.1 (DOE 1988a) at SNL/NM. The Groundwater Surveillance Task is the monitoring activity associated with the Groundwater Protection program. The purpose of this task is to detect any contaminants entering SNL/NM from outside sources and any contaminants leaving SNL/NM. The specific objective of the task is to establish the impact of DOE facilities operations on groundwater quantity and quality. Data collected are used in baseline hydrogeochemical characterization and groundwater contamination detection monitoring.

The CWL currently must meet the interim status Resource Conservation and Recovery Act (RCRA) Groundwater Monitoring Regulations (40 CFR 265, Subpart F). In February 1993, the CWL final closure plan and postclosure permit application was approved by all concerned parties (SNL 1992a and 1993f). The current groundwater monitoring requirements for this site are discussed in detail in Sections 2.0 and 7.0 of the closure plan. The sampling and analysis plan is provided in Appendix $\mathrm{G}$ of the closure plan.

The MWL is regulated by the U.S. Environmental Protection Agency (EPA) as a solid waste management unit (SWMU) under RCRA. Groundwater monitoring activities at the MWL are in accordance with the requirements of 40 CFR 264, Subpart F, Section 264.101, "Corrective Action for Solid Waste Management Units." 
Groundwater sampling activities at TA-II and the LWDS are conducted as part of the sitespecific investigations under the Hazardous and Solid Waste Amendments (HSWA) permit for SNL/NM.

\subsection{THE SNL/NM GROUNDWATER MONITORING WELL NETWORK}

The following paragraphs and Table 7-1 summarize SNL/NM groundwater monitoring activities performed in CY94.

As part of the basewide groundwater monitoring, samples were collected from between 17 and 19 SNL/NM, KAFB, New Mexico Environment Department (NMED), and DOE monitoring wells and 3 or 4 springs (including Hubbell Spring on the Isleta Indian Reservation) during each sampling event. Static water levels were measured in 37 SNL/NM and KAFB wells and 2 springs (including Hubbell Spring) (Figure 7-1). Basewide sampling occurred in March, June, and September 1994.

The population of basewide sampling sites may be divided into two sample sets (east and west of Hubbell Spring and Sandia faults) on the basis of geographic location and water level elevation at a given site. Burn Site Well, Sol se Mete Spring, Coyote Spring, Greystone Manor Well, Schoolhouse Well, Explosives Ordnance Disposal (EOD) Hill Well, South Fence Road \#3, South Fence Road \#4, and Hubbell Spring are considered to be east of the faults or along the line of the fault complex. All of the other wells are considered to be west of the faults.

CWL groundwater monitoring was performed at nine wells surrounding the landfill, including two background wells. Four of the nine wells were added in August 1994. Annual assessment monitoring was performed at the CWL in February 1994; quarterly assessment sampling took place in May, August, and November.

MWL groundwater monitoring was performed at five monitoring wells in the vicinity of the landfill, including one background monitoring well and one monitoring well located inside the landfill. Semiannual detection groundwater sampling took place at the MWL during March through May, and October 1994.

LWDS groundwater monitoring was performed at two monitoring wells, one adjacent to the LWDS lagoons, and the other adjacent to the location of the buried LWDS waste line immediately outside TA-IV. Samples were collected quarterly, during March, June, September, and December 1994.

TA-II groundwater was sampled at three monitoring wells in the vicinity of TA-II: one well in the vicinity of the Building 901 septic leachfield, one background monitoring well, and one well west of Building 906. The first two wells were sampled quarterly, during January, April, July, and October 1994. The well west of Building 906 was completed in June and sampled in October. 
Table 7-1. Groundwater Monitoring Sampling Frequency

\begin{tabular}{|c|c|c|c|c|c|}
\hline & Basewide & $\begin{array}{c}\text { Chemical } \\
\text { Waste } \\
\text { Landfill }\end{array}$ & $\begin{array}{l}\text { Mixed } \\
\text { Waste } \\
\text { Landfill }\end{array}$ & $\begin{array}{l}\text { Liquid } \\
\text { Waste } \\
\text { Disposal } \\
\text { System }\end{array}$ & $\begin{array}{c}\text { Technical } \\
\text { Area II }\end{array}$ \\
\hline & & & & $X$ & $\mathrm{X}$ \\
\hline \multicolumn{6}{|l|}{ January } \\
\hline February & & $X$ & & & \\
\hline March & $X$ & & $X$ & $X$ & \\
\hline April & & & $\mathrm{X}$ & & $\mathrm{X}$ \\
\hline May & & $X$ & $\mathrm{X}$ & & \\
\hline June & $\mathrm{X}$ & & & $\mathrm{X}$ & \\
\hline July & & & & & $X$ \\
\hline August & & $\mathrm{X}$ & & & \\
\hline September & $X$ & & & $X$ & \\
\hline October & & & $X$ & & $\mathrm{X}$ \\
\hline November & & $\mathrm{X}$ & & & \\
\hline December & & & & $\mathrm{X}$ & \\
\hline
\end{tabular}

\subsection{WATER LEVEL MEASUREMENTS}

Monthly basewide water level measurements were taken during 1994 at 37 wells and 2 springs in accordance with SNL/NM procedure FOP95-02 (SNL 1994f). Seven of the wells included in the basewide network are located east of the faults, with depths to groundwater varying from 54 to 100 feet (ft); all other wells are west of the faults, with depths to groundwater varying from approximately 200 to $500 \mathrm{ft}$. Monthly summaries of all basewide depth-to-water measurements and corresponding water surface elevations made at SNL/NM from January through December 1994 are included in Calendar Year 1994 Annual Groundwater Monitoring Report (SNL 1995b). Additional water-level elevations were measured in all CWL and MWL wells prior to each sampling event to ensure that the monitoring well network at each facility consisted of at least one upgradient well and three downgradient wells as required by 40 CFR 265.91. Monthly water level measurements of the TA-II monitoring well network were also 


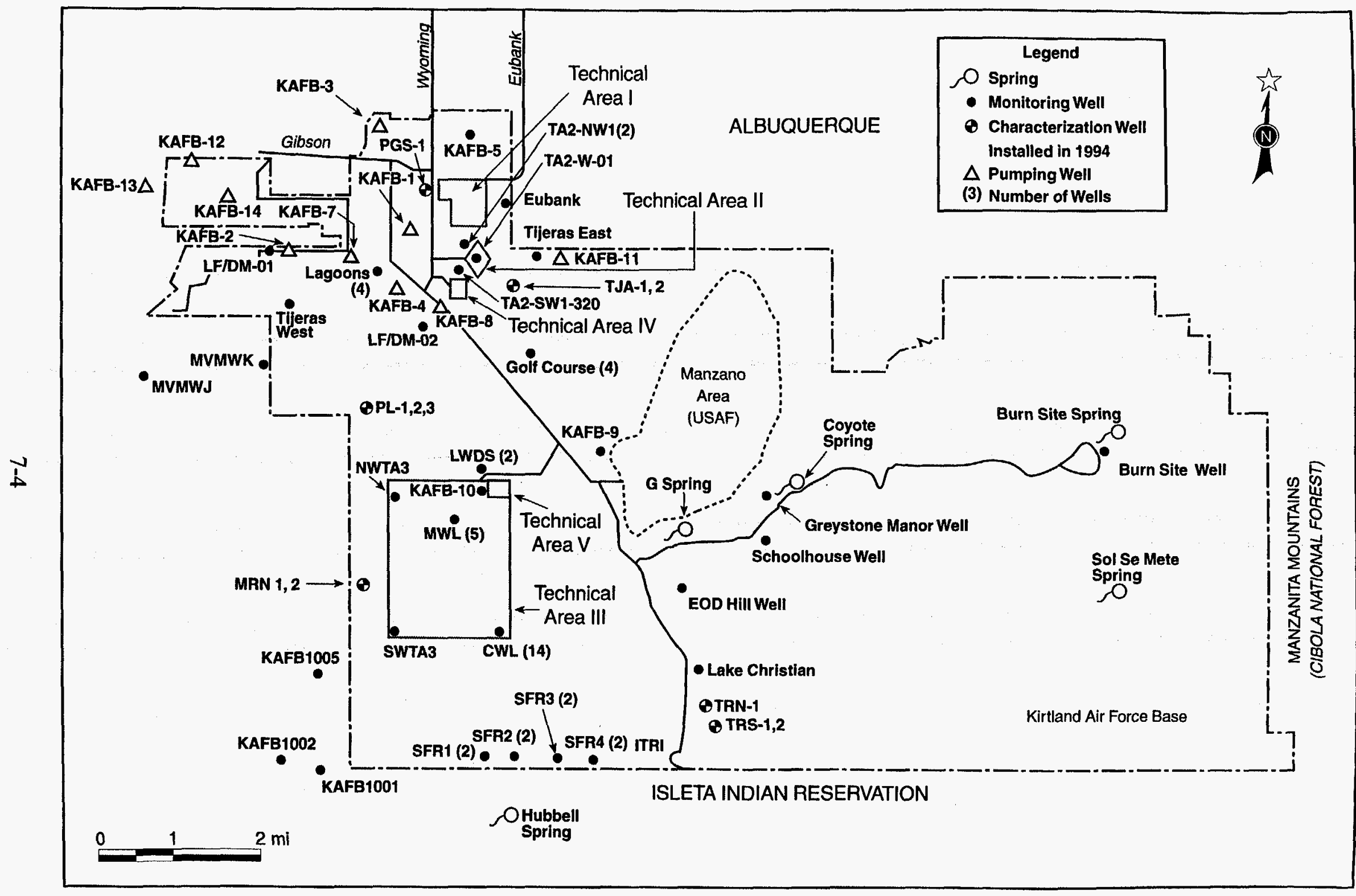

Figure 7-1. Locations of Sandia National Laboratories and Kirtland Air Force Base Wells and Springs 
performed. The water level data collected during 1994 and the subsequent groundwater elevation analyses are discussed in the following sections.

\subsubsection{Production Well Pumping}

Over 1.1 billion gallons were pumped from KAFB production wells in 1994. About twice as much water is pumped during the summer months, when there is a high water demand, than in the winter months. For comparison with the monitoring well water-level data, the KAFB production well pumping volumes are plotted by month in Figure 7-2. Figure 7-3 shows production trends since 1985 for KAFB production wells. There is a clear seasonal pattern of an increase in pumping during the spring and summer months, followed by a significant drop in pumping during the fall, to the lowest pumping rates in winter. As shown in Figure 7-4, not all of the KAFB production wells have been in service continuously over the past 5 years. The influence of a production well on nearby monitoring wells is affected by the volume pumped and the number of days that the production well is in use. The effects of discharge from nearby production wells on individual monitoring wells are discussed where appropriate in the following section.

Many of the City of Albuquerque wells are located along the northern boundary of KAFB. Some of these well fields pump considerably more than the KAFB wells. Their effect on seasonal fluctuations in groundwater is not known at this time. The effect of well-field pumping on the groundwater flow direction and hydraulic gradient is discussed in Section 7.3.3.

Due to a lack of spatial data, the shape and extent of the cone of depression formed by the production wells is not well known at this time, but is currently under investigation.

\subsubsection{Monitor Well Hydrographs}

7.3.2.1 Chemical Waste Landfill - Twelve wells are presently monitored for water level determinations at the CWL. Three of these wells were installed in 1994 and have not yet been added to the basewide monitoring network. The networks of shallow and deep wells satisfy the requirements of 40 CFR 265.91 in that there is at least one well located hydraulically upgradient and three wells located hydraulically downgradient from the facility. For the shallow well network, CWL-BW3 is hydraulically upgradient and CWL-MW1A, CWL-MW2A, and CWL-MW3A are hydraulically downgradient from the site. Similarly, the network of deep wells is located such that CWL-BW1 and CWL-BW2 are hydraulically upgradient from the CWL, and CWL-MW2 and CWL-MW3 are hydraulically downgradient.

Water levels in the CWL wells generally decreased slowly throughout the year. Some wells showed a slight rise in water levels in April while others continued to decrease. No significant seasonal fluctuations are evident from these data. CWL-MW4 showed a greater range of fluctuations, with decreases in water levels from January to March of approximately $10 \mathrm{ft}$ followed by a 4-ft rise. These fluctuations may be attributed to slow recovery of the well after sampling events and/or inaccurate measurements. 


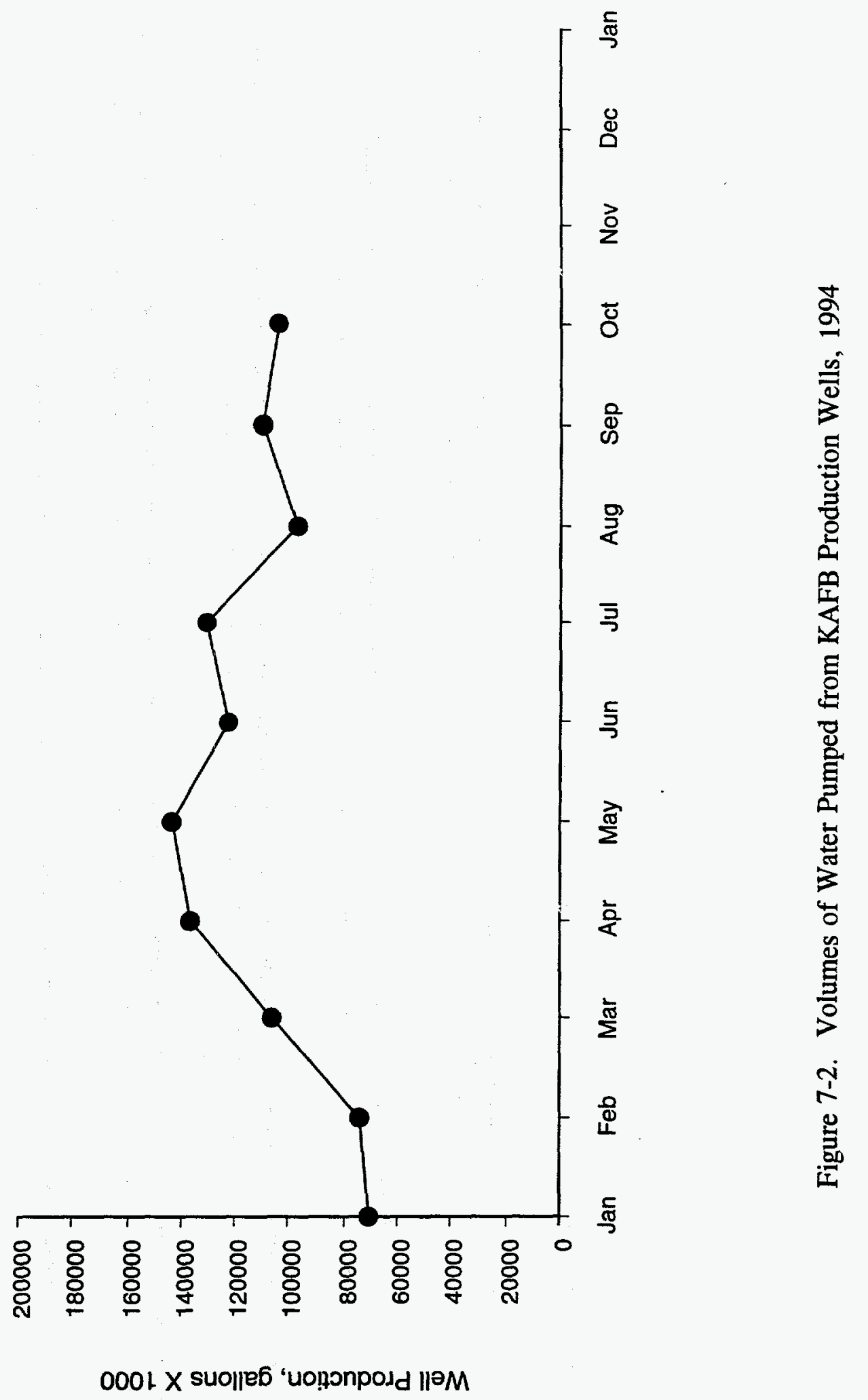




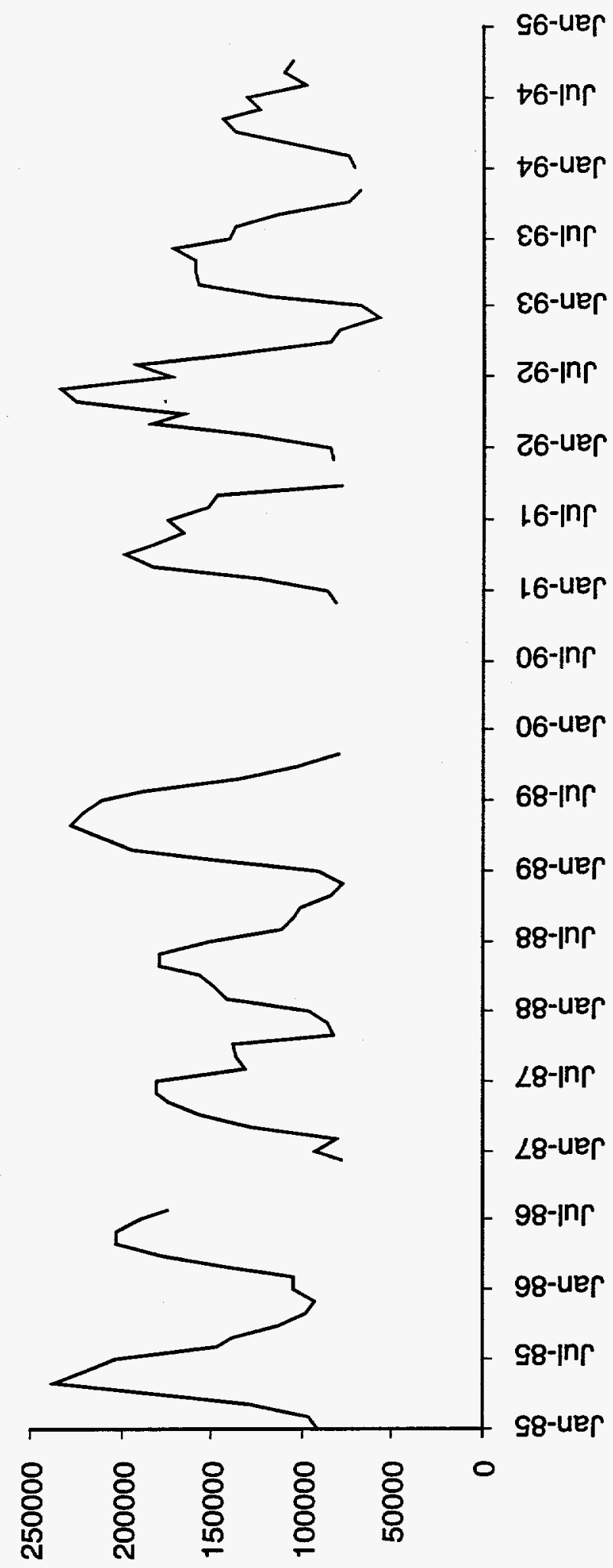



000 I X suol|e6 'uo!̣onpodd ॥əM 


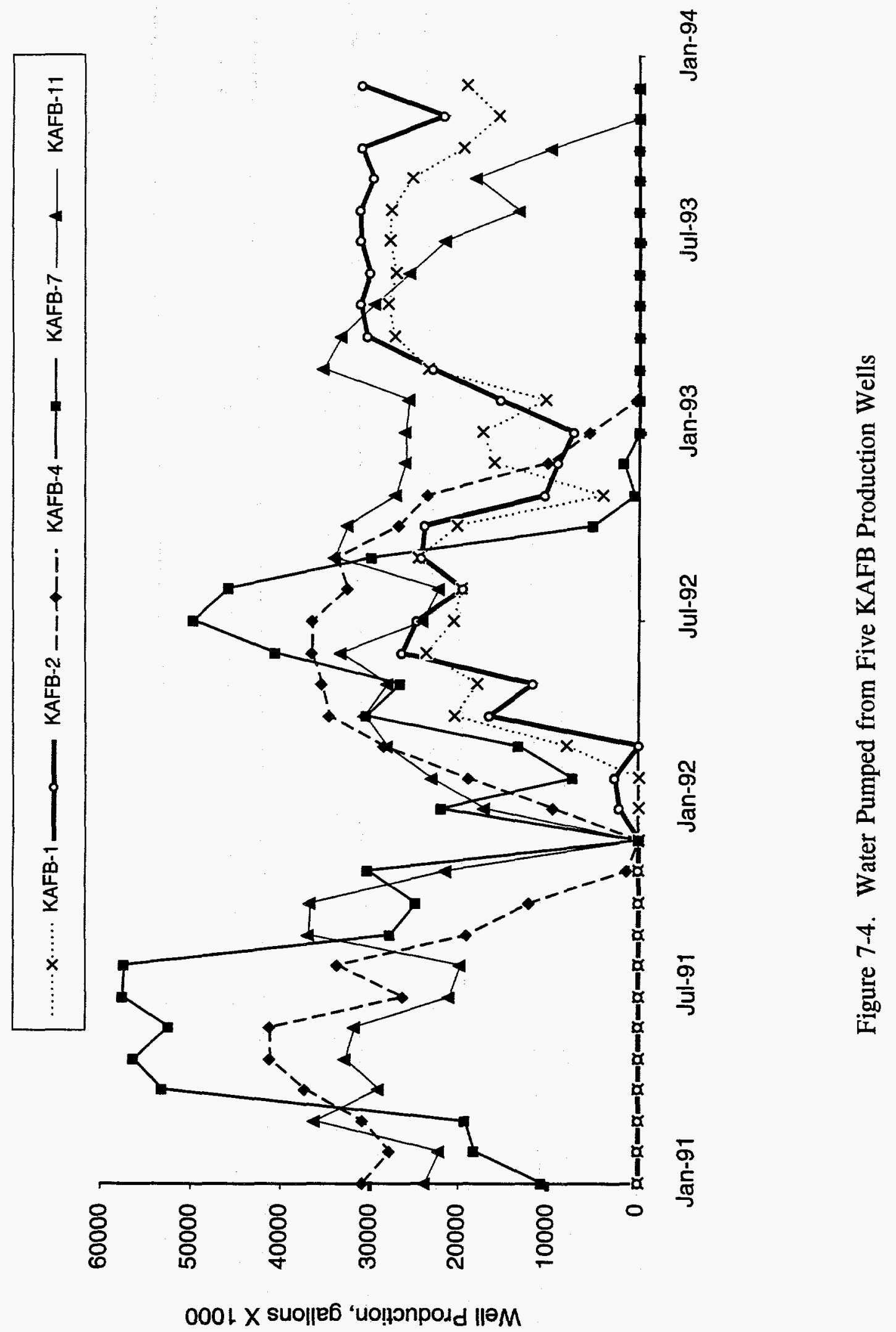


Several of the new wells were installed as nested wells, with one shallow well and one deep well. Water level data from these wells indicate a downward vertical gradient of approximately 0.006 .

As shown in Figure 7-5, water levels at the CWL have decreased at an average rate of 0.85 foot per year ( $\mathrm{ft} / \mathrm{yr}$ ) since measurements began in 1985. This water level decline is probably due to groundwater withdrawal from Albuquerque and KAFB water supply wells north of TA-III. Future changes in the rate of decline will depend upon the withdrawal rates from the production wells. Slight fluctuations that may be attributed to seasonal differences in pumping rates are apparent in Figure 7-5.

7.3.2.2 Mixed Waste Landfill - Water levels in the MWL monitoring wells were relatively constant. Anomalously high levels measured in MWL-BW1 and MWL-MW3 in January are probably due to measurement errors. These wells contain dedicated monitoring equipment which makes manual water-level measurements difficult. Adjustments will be made regarding how water levels are measured in wells with dedicated equipment.

No seasonal fluctuations in water levels are apparent at the MWL in 1994. Figure 7-6 shows the hydrographs of the MWL monitoring wells since 1989. With the exception of MWL-BW1, water levels are declining at an average rate of $0.85 \mathrm{ft} / \mathrm{yr}$, the same rate of decline as in the CWL wells.

7.3.2.3 Other Technical Area III Wells - Water levels in wells in TA-III, other than those described above, were relatively constant. SW-TA3 shows a slight increase in water levels throughout the year, possibly due to slow recovery after sampling events. Water levels in KAFB-10 show a decrease from January through May 1994 followed by a slight rise until August. January and April measurements were anomalously high. NW-TA3 water levels were fairly constant throughout the year. Figure 7-7 shows the hydrographs for these three wells since 1989. NW-TA3 and SW-TA3 had an average water level decline of approximately 2.0 $\mathrm{ft} / \mathrm{yr}$, while KAFB-10 had an average water level decline of $1.0 \mathrm{ft} / \mathrm{yr}$. The erratic levels in SWTA3 make interpretation of long-term trends difficult. The variability in the rate of decline in the TA-III monitoring wells is probably due to several factors, including lithologic heterogeneities in aquifer material, proximity to KAFB pumping wells, and differences in the depths of wells and screen lengths.

7.3.2.4 South Fence Road - Wells located along the South Fence Road were installed to assess the effects that the fault complex (discussed in Section 1.4) has on groundwater flow. SFR-3P and SFR-3T were added to the monitoring well network in March 1994. SFR-3P is completed in the Santa Fe Group alluvial sediments and SFR-3T is completed in the underlying bedrock. The hydrographs for these wells show increasing water levels in SFR-3T and fairly constant water levels in SFR-3P. Additional water level surveillance is necessary to evaluate these wells. 


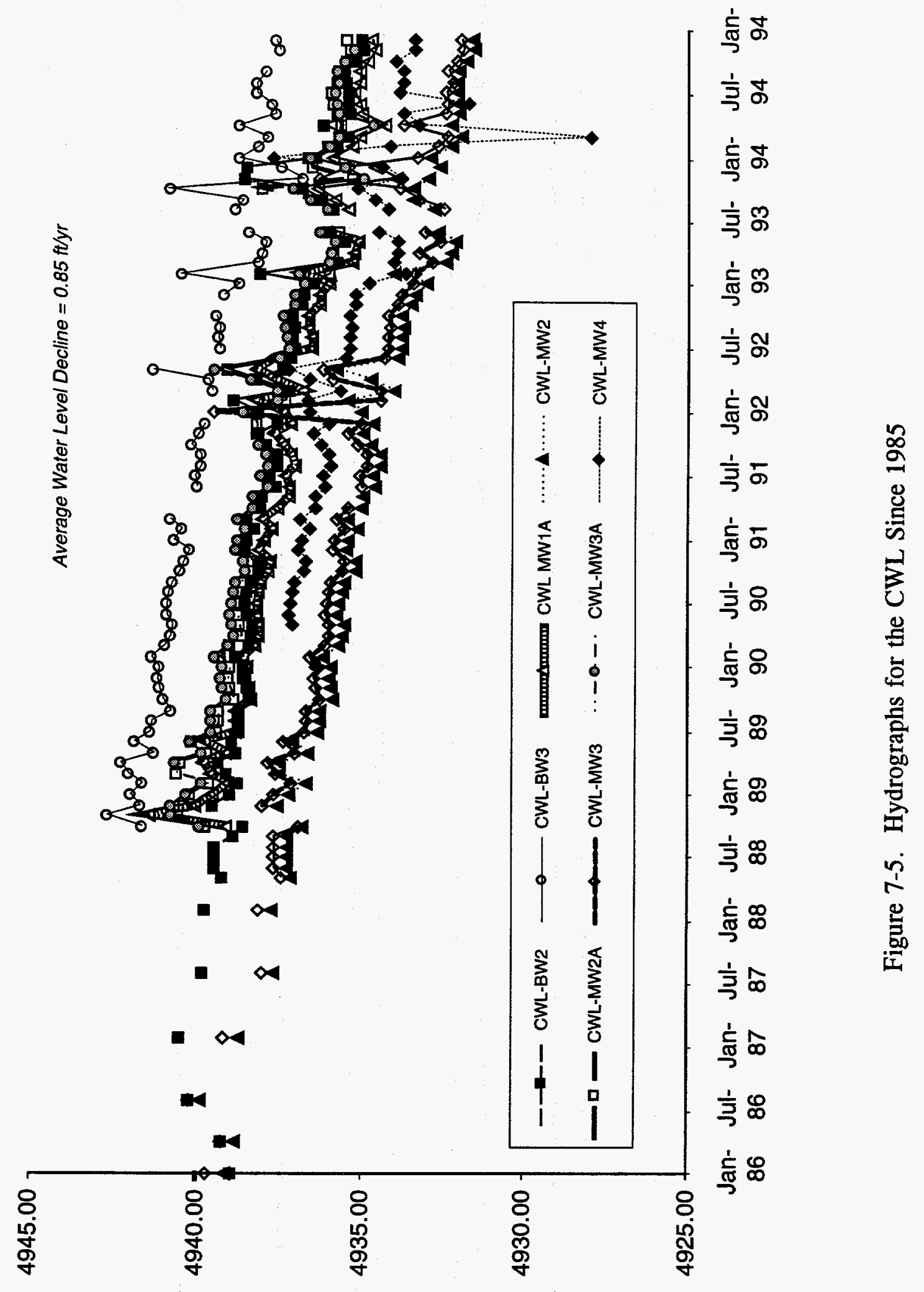

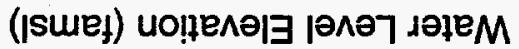




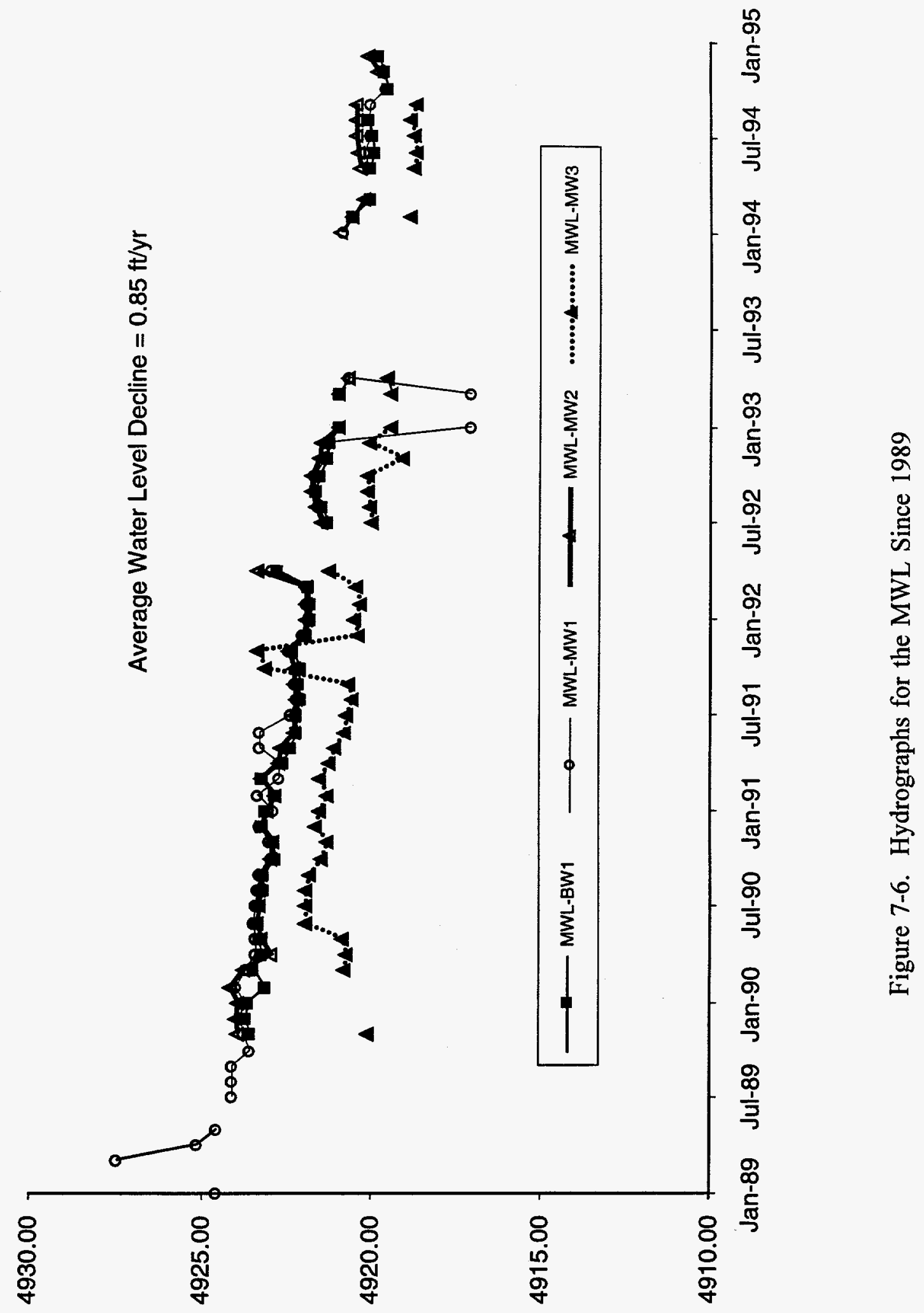

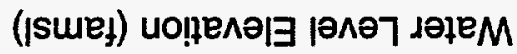




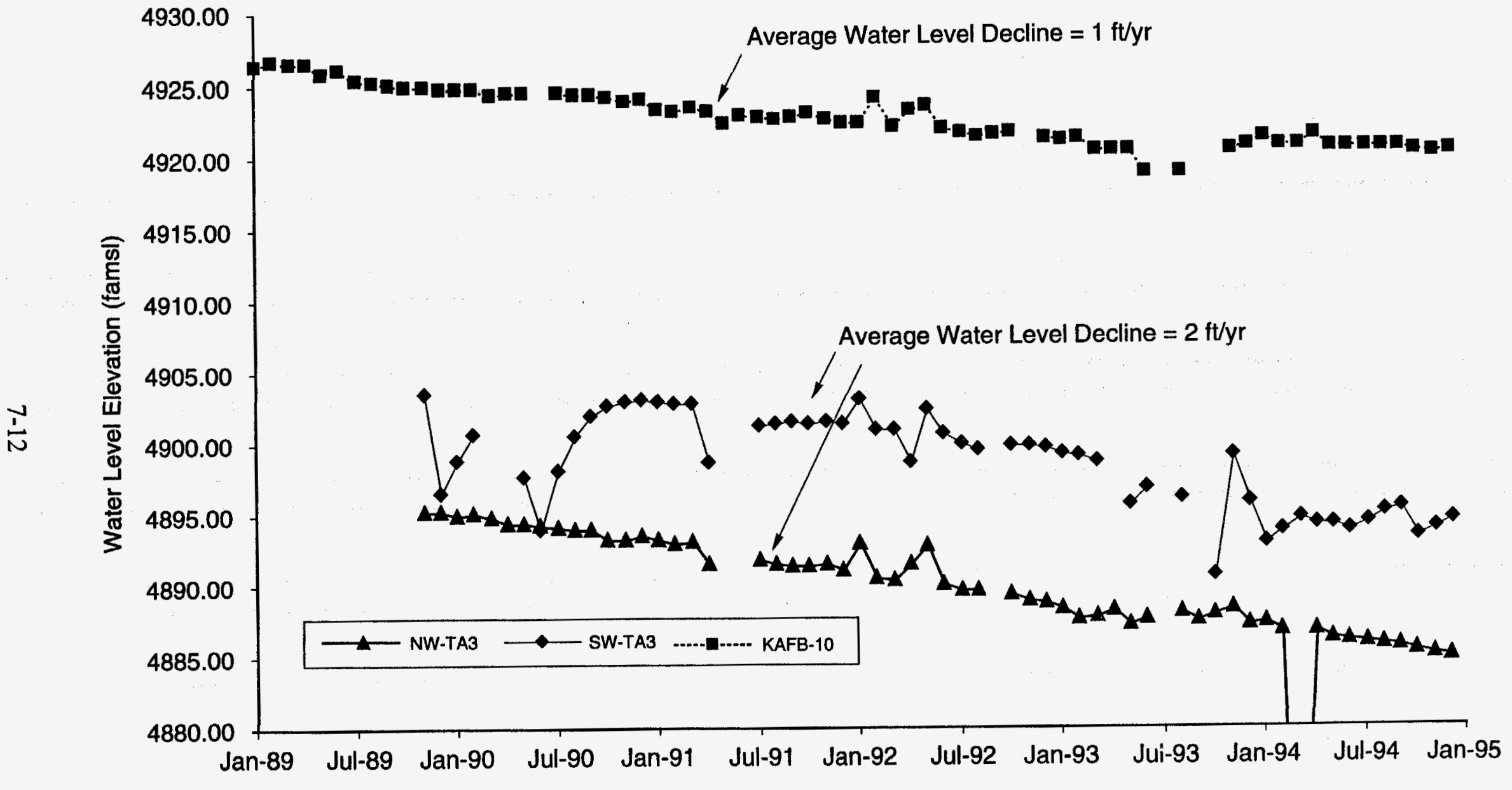

Figure 7-7. Hydrographs for Other TA-III Wells Since 1989 
7.3.2.5 East of the Fault Zone - The wells located east of the fault complex have much shallower water levels ( 50 to $200 \mathrm{ft}$ ) than wells west of the fault zone (300 to $500 \mathrm{ft}$ ). Some of the wells in this region are completed in shallow alluvium while others are completed in bedrock. The hydrographs of the wells east of the fault zone indicate that the aquifers in this region are not affected by pumping from KAFB production wells. Fluctuations in water levels during the year may be a result of response of the shallow water table aquifer in this region to precipitation events.

7.3.2.6 KAFB Sanitary Lagoon - The KAFB Sanitary Lagoon monitoring wells are located close to two active KAFB production wells (KAFB-4 and KAFB-7). Water levels in previous years relate to production well pumping rates: the monitoring well water levels declined during periods of increased discharges and rose during periods of decreased discharges. This indicated a direct response of the aquifer to pumping in that area; however, KAFB-4 and KAFB-7 were shut down in February 1993. KAFB-4 began to be used again in September 1994. Since early 1993, water levels in the KAFB Sanitary Lagoon wells have fallen slightly and appear to fluctuate more sporadically. No clear seasonal trend was apparent during 1994 as it was in previous years. Figure 7-8 shows the historical water-level trends for these monitoring wells together with the graph of the water volumes pumped per month from KAFB-4 and KAFB-7 and from all KAFB production wells. Seasonal fluctuations are clearly evident when KAFB-4 and KAFB-7 wells were pumping. Water levels in the KAFB Sanitary Lagoon wells were declining at a rate of approximately $1.5 \mathrm{ft} / \mathrm{yr}$ in 1994, although water levels in 1994 appear to be decreasing more rapidly. Additional study is needed to evaluate the influences on the groundwater regime in this area.

7.3.2.7 Tijeras Arroyo - Wells located near Tijeras Arroyo exhibited fairly steady declines in water levels during 1994. Tijeras East shows a decline in water levels since 1991 of $0.7 \mathrm{ft} / \mathrm{yr}$ (Figure 7-9). There may also be some response in Tijeras East to pumping from production well KAFB-11, located near this well. No other wells along Tijeras Arroyo exhibit fluctuations indicative of response to pumping.

7.3.2.8 Golf Course - The Golf Course wells continued to show a fairly steady rise in water levels over the spring, summer, and early fall of 1994. The water level dropped in the Golf Course West well in December. The rate of increase in this well $(0.4 \mathrm{ft} / \mathrm{yr})$ was much less in 1994 than in previous years $(2 \mathrm{ft} / \mathrm{yr})$. Water levels in the Golf Course wells have been rising steadily at a rate of between 1.5 and $2.7 \mathrm{ft} / \mathrm{yr}$ (Figure 7-10). The potentiometric surface in this area is approximately $150 \mathrm{f}$ higher than the regional potentiometric surface, which may be a result of a perched zone, mounding of the regional aquifer, or a combination of both effects. Recharge to the groundwater may be occurring locally from irrigation of the golf course. The nature of the anomalously high water levels in this area is the subject of an SNL/NM Site-Wide Hydrogeologic Characterization Project study.

7.3.2.9 Technical Area II Water Level Measurements - Water level elevations for all TA-II monitoring wells were measured monthly during 1994. Except for minor fluctuations, groundwater elevations generally were constant over the year. The largest water-level elevation fluctuations occurred in monitoring well TA2-NW1-595, decreasing $2.91 \mathrm{ft}$ between February and June 1994. 
000L X suol|e⿹
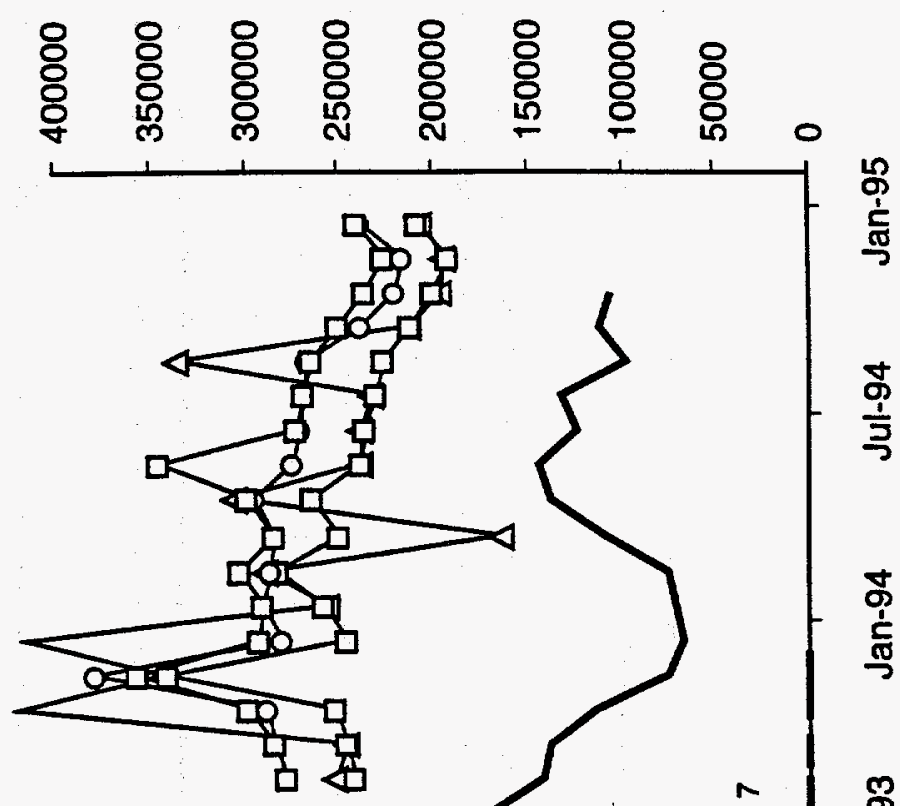


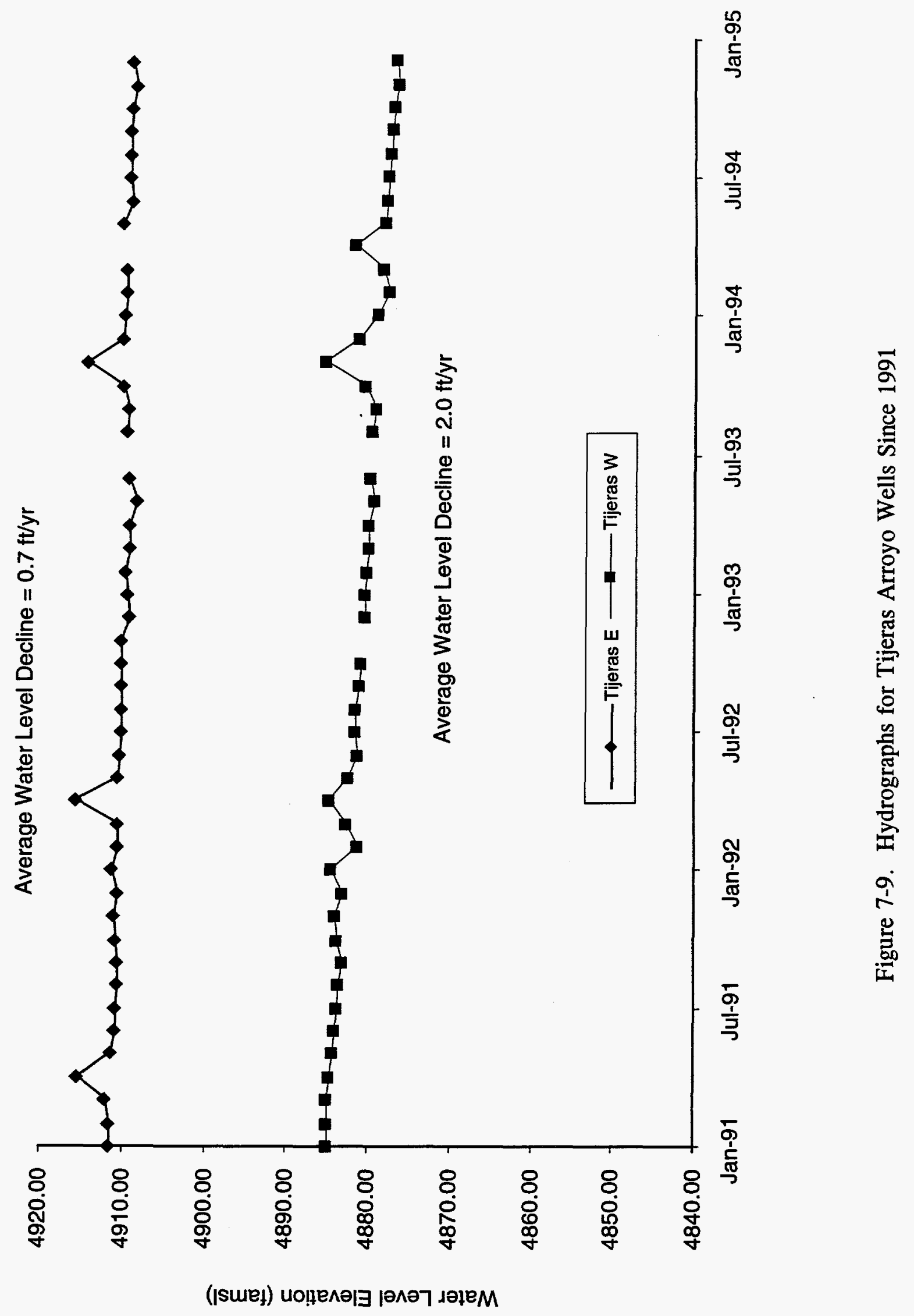




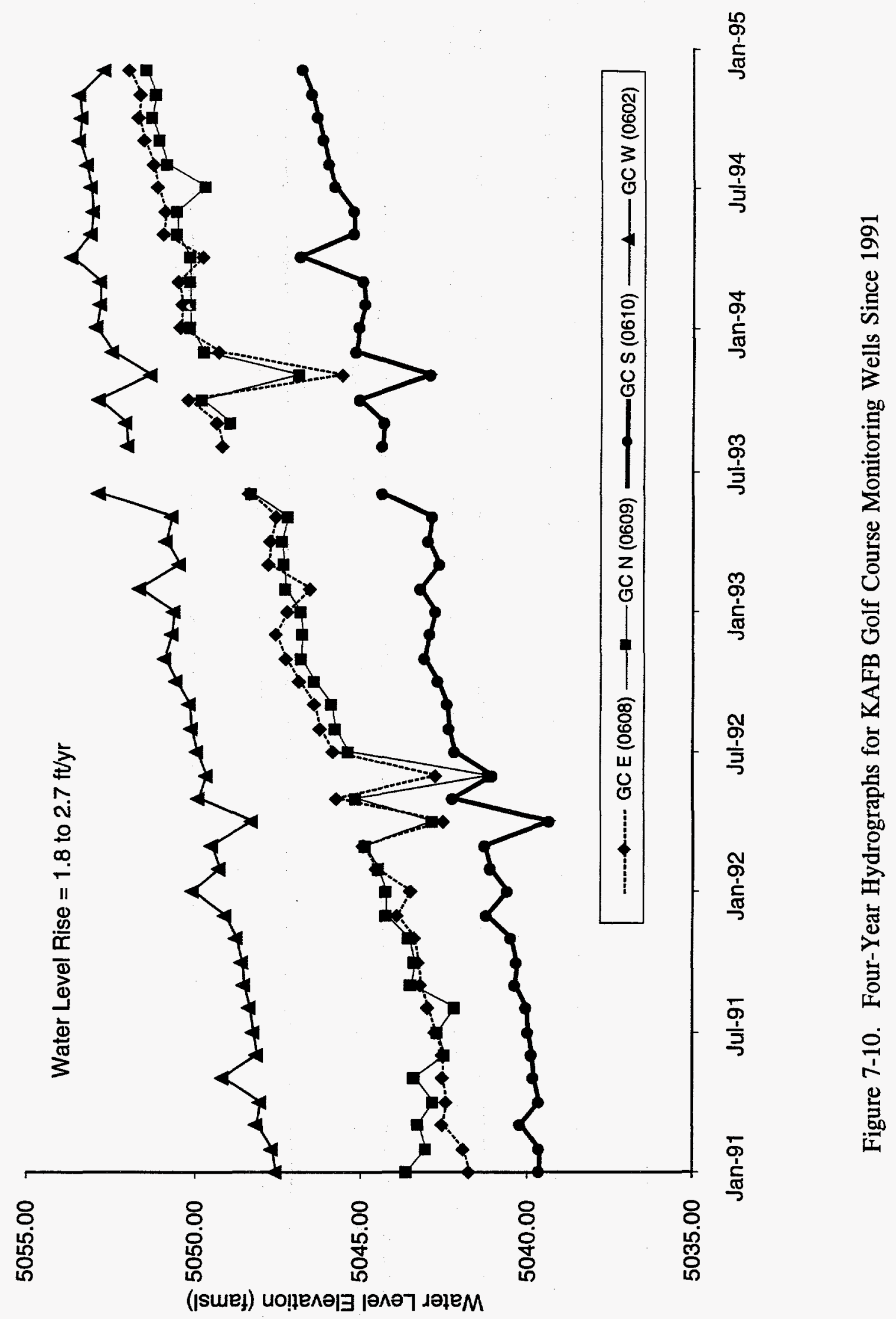




\subsubsection{Potentiometric Surface}

To determine the general horizontal hydraulic gradient throughout the SNL/NM-KAFB area, groundwater surface elevations have been measured in all accessible SNL/NM monitoring wells and adjacent KAFB and NMED monitoring wells on a monthly basis since May 1989 . Static water-level data from all these monitoring wells were used as indicators of the potentiometric surface at various locations. While many of the water levels appear to represent the water table, the water levels measured in some of the wells indicate confined aquifer conditions.

A potentiometric surface map for July 1994 was prepared using static water-level data representative of the unconfined water table (Figure 7-11). Three wells (KAFB1001, KAFB1002, and KAFB1005) not presently in the monitoring network were used to complete the southern portion of the 4900-ft contour. Water levels in these wells were extrapolated assuming a steady water level decline between December 1993 and October 1994.

The direction of groundwater flow is perpendicular to the equipotential lines. The apparent direction of groundwater flow in the KAFB area currently is west and northwest, in contrast to the southwesterly direction reported by Bjorklund and Maxwell (1961). This change in flow direction is a result of groundwater pumping by KAFB and nearby City of Albuquerque production wells. Pumping from these well fields has created an apparent cone of depression in the potentiometric surface in the northern portion of KAFB west of the faults. Although efforts were made to construct a potentiometric surface map that is representative of the water table, it is clear that the data set of water level elevations contains several ambiguities which complicate the interpretation of a potentiometric surface. First, it is possible that some of the water levels in the wells reflect completions in different saturated units; therefore, the data set does not represent the elevation of a single groundwater unit. Second, the screens of the wells are of varying lengths. The KAFB production wells are screened over large intervals, usually starting at the water table and extending several hundred feet into the saturated zone. The monitoring wells typically have 20 -ft screens placed across the water table. If the groundwater flow is not uniformly horizontal (i.e., vertical gradients exist) then the longer screen lengths do not provide true groundwater table elevation data; rather, they provide the average groundwater potential over the length of the screen, which may differ from a piezometer measurement at the water table if vertical gradients are present. The potentiometric surface contour map (Figure 7-11) is currently the best available interpretation of the data. The Site-Wide Hydrogeologic Characterization Project activities are, in part, investigating these complications of the potentiometric surface data interpretation.

\subsection{Groundwater Quality}

Groundwater monitoring activities conducted by SNL/NM during 1994 include sampling the basewide, CWL, MWL, LWDS, and TA-II monitoring wells on periodic schedules for water quality analyses. The following sections describe the sampling activities and analytical results for each of the projects for CY94. Chemical analyses were conducted in accordance with EPAapproved methods (e.g., SW-846 [EPA 1986]) by laboratories under contract to SNL/NM. 


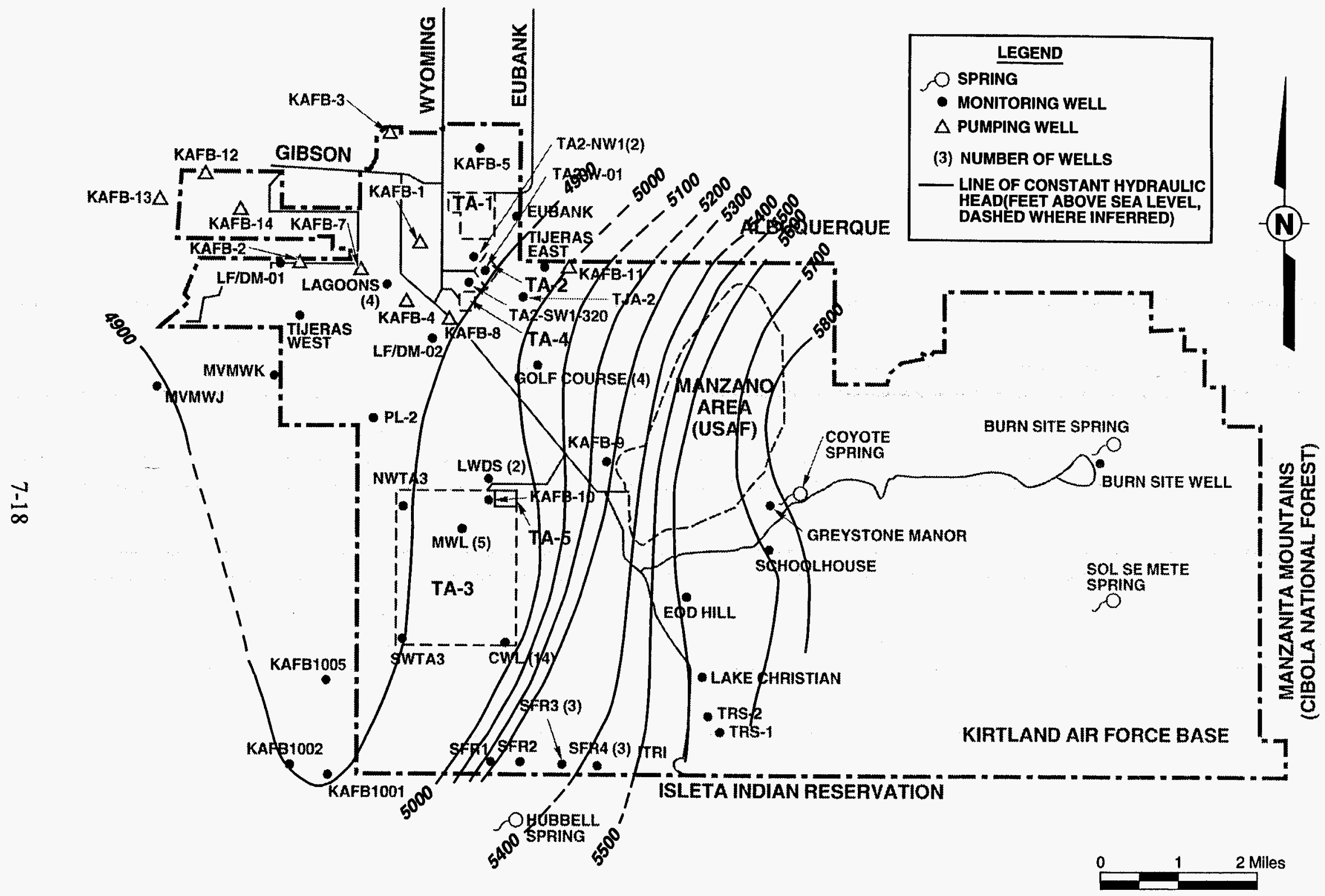

Note: Contours derived from monitoring well water levels only

Figure 7-11. KAFB Potentiometric Surface Map, July 1994 


\subsubsection{Groundwater Sampling}

Groundwater surveillance sampling for the basewide project included between 17 and 19 wells and 3 and 4 springs across KAFB and SNL/NM during each event. Three basewide groundwater monitoring events (March, June, and September 1994) continued to establish background characteristics of the regional groundwater system and provide contaminant detection monitoring. Results for the December 1993 basewide sampling event are included in this 1994 annual report. Details of the quarterly sampling events may be found in the reports on quarterly basewide groundwater monitoring for December 1993 (IT 1994c), and March, June, and September 1994 (IT 1994d, 1994e, and 1994f). Certain analyses from the September 1994 basewide sampling event were not completed by the contract laboratory in time for inclusion in this report.

Sampling at the CWL in 1994 included quarterly assessment monitoring and annual groundwater quality monitoring. Details of both monitoring programs for 1994 are found in the CWL annual groundwater assessment monitoring report (IT 1994g) and in the quarterly groundwater assessment monitoring reports (IT 1994h, 1994i, and 1994j).

Semiannual groundwater sampling from MWL monitoring wells was conducted from March to May 1994, and during October 1994. Details of the sampling events are in the MWL reports on semiannual groundwater sampling (IT 1994k and 19941).

Quarterly groundwater sampling from both LWDS monitoring wells was conducted in March, June, September, and December 1994, and additionally for LWDS-MW1 in November 1994. Details of the March, June, and September 1994 sampling events may be found in the LWDS groundwater monitoring report (IT 1994m). Analytical results of the November and December 1994 events are not included in this report.

Quarterly groundwater sampling from TA-II monitoring wells was conducted in January, April, July, and October 1994.

\subsubsection{Sampling Procedures and Methods}

Samples were collected for the Groundwater Surveillance Task in 1994 in accordance with the Sitewide Groundwater Monitoring Program Sampling and Analysis Plan (SNL 1993g). The protocols for collection and analysis of representative groundwater samples at the CWL in 1994 are specified in the Chemical Waste Landfill Final Closure Plan and Post Closure Permit Application, Appendix G, Sampling and Analysis Plan for Groundwater Assessment Monitoring at the Chemical Waste Landfill, Revision 4 (SNL 1992a), which includes annual sampling for all Appendix IX parameters and quarterly sampling for Appendix IX volatile organic compounds (VOCs) and total metals. MWL sampling and analysis activities were conducted in accordance with the Sampling and Analysis Plan for Groundwater Detection Monitoring at the Mixed Waste Landfill (SNL 1994g, draft). LWDS sampling and analysis activities were conducted in accordance with the site-specific sampling plan (unpublished). Samples for TA-II monitoring were collected in accordance with the basewide protocol during the January, April, and July 1994 sampling events, and in accordance with the Site-Specific Sampling and Analysis Plan, 
TA-II Groundwater Monitoring (SNL 1994h) during October 1994. Specific details of the sample collection and analysis for groundwater are presented in Groundwater Protection Program.

\subsubsection{Groundwater Surveillance Results}

Results of the basewide groundwater water-quality monitoring in December 1993 and March, June, and September 1994, are presented in this section.

Prior to and immediately after the sampling of each well, a set of field water-quality parameters was measured. These parameters included $\mathrm{pH}$, temperature, specific conductivity, and turbidity. Detailed discussion of these measurements and turbidity measurements can be found in the appropriate quarterly reports.

Basewide sampling during 1994 represents a list that follows 40 CFR 265, Subpart F. The list is representative of potential contaminants, indicators of potential contamination, and safe drinking-water parameters. Because total organic halogens (TOX) analysis may not accurately indicate potential contamination, VOCs (EPA method 8260). During the March and September 1994 sampling events, groundwater was also sampled for background characterization of selected radionuclides, consisting of gross alpha and gross beta activity; isotopic analyses for plutonium, uranium $(\mathrm{u})$, thorium $(\mathrm{Th})$, radium $(\mathrm{Ra})$, and strontium-90; and tritium (H-3). In addition, groundwater samples were screened for gamma-emitting radionuclides.

Analytical results from the December 1993, and March, June, and September 1994 sampling events are presented in the appropriate quarterly reports (IT 1994c, 1994d, 1994e, and 1994f), which contain the results of all analyses except for herbicides and pesticides, which have not been detected in any basewide groundwater sampling events.

7.4.3.1 Volatile Organic Compounds - VOCs detected above maximum contaminant levels (MCLs) are all common laboratory solvents (e.g., acetone, 2-butanone, carbon tetrachloride, and methylene chloride). The fact that these contaminants are present in quality control samples (e.g., trip blanks, equipment blanks, and method blanks) suggests that they were introduced at the laboratory and do not indicate groundwater contamination. The minor concentrations of unknown compounds tentatively identified by a library search, such as trimethyl silanol, fluorotrimethyl silane, methoxytrimethyl silane, chlorodifluoromethane, tetrahydrofuran, and 1,1,2-Trichloro-1,2,2-trifluoroethane, also probably represent laboratory contamination.

7.4.3.2 Inorganic Compounds and Phenolics - The east-side basewide wells are typically characterized by relatively low $\mathrm{pH}$, high alkalinity, high concentrations of bromide, chloride, fluoride, and sulfate, and lower nitrate-plus-nitrite (NPN) concentrations, relative to the west-side wells. Phenolics were not detected in the groundwater regardless of the well or spring location. 
7.4.3.3 Metals - The wells and springs sampled east of the faults typically have higher concentrations of calcium, magnesium, potassium, and sodium than the wells west of the faults. This corresponds to the higher alkalinity and ion concentrations for east-side waters. Table 7-2 contains a summary of the metals sampling results above MCLs.

7.4.3.4 Gamma-Emitting Radionuclide Screening - Gamma-spectroscopy radionuclide screening detected radionuclides that are naturally occurring isotopes, with minor exceptions, and that are not indicators of anthropogenic radioactive contamination. Isotopes of beryllium, scandium, and cobalt detected during the screenings are thought to represent false positives and will be investigated through more thorough data analysis.

7.4.3.5 Isotopic Radionuclide and Tritium Analyses - Radionuclide analyses detected H-3 locally above the minimum detectable activity (MDA), but not above the DOE guideline of 80,000 picocuries per liter $(\mathrm{pCi} / \mathrm{L})$. Isotopic radionuclide analysis detected naturally occurring components of the $U$ and Th decay chains in activities most often below the DOE guidelines. Activity concentrations from $\mathrm{Ra}$ isotopes can be seen to occasionally exceed the DOE guidelines, but analysis values of individual isotope are within DCG values.

\subsubsection{Chemical Waste Landfill Assessment Monitoring Results}

Annual sampling for assessment monitoring at the CWL occurred in February 1994; quarterly sampling took place in May, August, and November 1994.

7.4.4.1 Volatile Organic Compounds - Appendix IX VOC laboratory analysis of 1994 CWL groundwater samples detected trichloroethylene (TCE) in monitoring wells CWL-MW1A, CWLMW2A, and CWL-MW3A (Table 7-3). Duplicate samples were collected from CWL-MW2A because it has the greatest known potential for detectable VOCs, and sampling system precision measurements cannot be made unless detectable quantities of analytes are present in the duplicate sample.

All other VOCs detected in the CWL groundwater samples are common laboratory solvents (e.g., acetone, 2-butanone, carbon disulfide, methylene chloride, and toluene). As these compounds were also detected in associated trip blanks, equipment blanks, and/or laboratory method blanks, their presence is considered to be a result of laboratory contamination and not an indication of groundwater contamination.

As concentrations of VOCs in the CWL monitoring wells have not varied significantly during this sampling year, there is no indication that these constituents are migrating away from the site. This conclusion is supported by the conceptual model of limited contaminant transport developed for this site in Section 3.0 of the CWL closure plan (SNL 1992a). In addition, all VOCs detected were below EPA MCLs and NMED action levels. 
Table 7-2. Summary of Groundwater Surveillance Metals Results Above Maximum Contaminant Levels (MCLs)

\begin{tabular}{|c|c|c|c|c|}
\hline Analyte & $\begin{array}{l}\text { Location } \\
\text { (Well or Spring) }\end{array}$ & $\begin{array}{l}\text { Concentration } \\
\quad(\mathrm{mg} / \mathrm{L})\end{array}$ & $\begin{array}{c}\mathrm{MCL} \\
(\mathrm{mg} / \mathrm{L})\end{array}$ & Month \\
\hline Arsenic & KAFB-10 & 0.055 & 0.05 & $03 / 94$ \\
\hline Barium & MVMW-J & 2.2 & 2.0 & $12 / 93$ \\
\hline Barium & MVMW-K & 2.1 & 2.0 & $12 / 93$ \\
\hline Barium & Burn Site Spring & 2.2 & 2.0 & $06 / 94$ \\
\hline Cadmium & KAFB-10 & 0.029 & 0.005 & $12 / 93$ \\
\hline Cadmium & KAFB-10 & 0.066 & 0.005 & $03 / 94$ \\
\hline Cadmium & KAFB-10 & 0.040 & 0.005 & $06 / 94$ \\
\hline Cadmium & Burn Site Spring & 0.014 & 0.005 & $06 / 94$ \\
\hline Cadmium & EOD Hill Well & 0.006 & 0.005 & 09/94 \\
\hline Cadmium & $\begin{array}{l}\text { EOD Hill Well } \\
\text { Duplicate }\end{array}$ & 0.007 & 0.005 & 09/94 \\
\hline Cadmium & $\begin{array}{l}\text { Golf Course } \\
\text { South Well }\end{array}$ & 0.008 & 0.005 & $09 / 94$ \\
\hline Chromium & CWL-BW2 & 0.26 & 0.10 & $12 / 93$ \\
\hline Chromium & CWL-BW2 & 0.76 & 0.10 & $12 / 94$ \\
\hline Lead & KAFB-10 & 0.23 & $0.015^{*}$ & $12 / 93$ \\
\hline Lead & KAFB-10 & 1.1 & $0.015^{*}$ & $03 / 94$ \\
\hline Lead & KAFB-10 & 0.65 & $0.015^{*}$ & $06 / 94$ \\
\hline Lead & MVMW-J & 0.05 & $0.015^{*}$ & $06 / 94$ \\
\hline \multicolumn{5}{|c|}{$\begin{array}{l}\text { Note: } \mathrm{mg} / \mathrm{L}=\text { milligrams per liter; KAFB }=\text { Kirtland Air Force Base; } \\
\text { MVMW = (New Mexico Environment Department) Mountain View Monitoring } \\
\text { Well; EOD = Explosives Ordnance Disposal; CWL-BW = Chemical Waste Landfill- } \\
\text { Background Well. } \\
\text { "EPA drinking-water action level. }\end{array}$} \\
\hline
\end{tabular}


Table 7-3. Summary of Chemical Waste Landfill Groundwater Sampling for VOCs

\begin{tabular}{|c|c|c|c|c|}
\hline VOC & $\begin{array}{l}\text { Location } \\
\text { (well) }\end{array}$ & $\begin{array}{l}\text { Concentration } \\
(\mathrm{mg} / \mathrm{L})\end{array}$ & $\begin{array}{c}\mathrm{MCL} \\
(\mathrm{mg} / \mathrm{L})\end{array}$ & Month \\
\hline TCE & CWL-MW1A & 0.001 & 0.005 & $05 / 94$ \\
\hline TCE & CWL-MW1A & 0.003 & 0.005 & $08 / 94$ \\
\hline TCE & CWL-MW1A & 0.002 & 0.005 & $11 / 92$ \\
\hline TCE & $\begin{array}{l}\text { CWL-MW2A } \\
\text { duplicate }\end{array}$ & 0.004 & 0.005 & $02 / 94$ \\
\hline TCE & $\begin{array}{l}\text { CWL-MW2A } \\
\text { duplicate }\end{array}$ & 0.003 & 0.005 & $05 / 94$ \\
\hline TCE & $\begin{array}{l}\text { CWL-MW2A } \\
\text { duplicate }\end{array}$ & 0.001 & 0.005 & $08 / 94$ \\
\hline TCE & $\begin{array}{l}\text { CWL-MW2A } \\
\text { duplicate }\end{array}$ & 0.003 & 0.005 & $11 / 94$ \\
\hline TCE & CWL-MW3A & 0.002 & 0.005 & $02 / 94$ \\
\hline TCE & CWL-MW3A & 0.002 & 0.005 & $05 / 94$ \\
\hline TCE & CWL-MW3A & 0.002 & 0.005 & $08 / 94$ \\
\hline TCE & CWL-MW4 & 0.007 & 0.005 & $11 / 94$ \\
\hline TCE & $\begin{array}{l}\text { CWL-MW28 } \\
\text { (deep) }\end{array}$ & 0.0018 & 0.005 & $11 / 94$ \\
\hline
\end{tabular}

7.4.4.2 Metals - All groundwater samples collected from CWL monitoring wells during 1994 were analyzed for Appendix IX metals plus iron. Nickel and chromium are the only metals on the list found to exceed the MAC limits set by the New Mexico Water Quality Control Commission (Table 7-4). 
Table 7-4. Summary of Chemical Waste Landfill Groundwater Sampling for Metals

\begin{tabular}{llccc}
\hline Analyte & $\begin{array}{l}\text { Location } \\
(\text { well })\end{array}$ & $\begin{array}{c}\text { Concentration } \\
(\mu \mathrm{g} / \mathrm{L})\end{array}$ & $\begin{array}{c}\text { MAC } \\
(\mu \mathrm{g} / \mathrm{L})\end{array}$ & Month \\
\hline Nickel & CWL-BW3 & 210 & 200 & $02 / 94$ \\
Nickel & CWL-BW3 & 470 & 200 & $05 / 94$ \\
Nickel & CWL-BW3 & 280 & 200 & $11 / 94$ \\
Chromium & CWL-BW3 & 88 & 50 & $02 / 94$ \\
Chromium & CWL-BW3 & 250 & 50 & $05 / 94$ \\
Chromium & CWL-BW3 & 97 & 50 & $08 / 94$ \\
Chromium & CWL-BW3 & 400 & 50 & $11 / 94$ \\
\hline $\begin{array}{l}\text { Note: } \text { MAC }=\text { maximum allowable concentration; } \mu \mathrm{g} / \mathrm{L}=\text { micrograms per liter; CWL-BW }= \\
\text { Chemical Waste Landfill-Background Well. } \\
\text { MAC limits set by the New Mexico Water Quality Control Commission. }\end{array}$ \\
\hline
\end{tabular}

\subsubsection{Mixed Waste Landfill Monitoring Results}

The 1994 semiannual MWL groundwater sampling events detected no contaminants of concern in groundwater at the MWL in concentrations above background levels or in concentrations exceeding EPA drinking water standards. No Target Analyte List (TAL) metals were detected in concentrations that exceeded the EPA MCLs. No TAL metals or radionuclides were detected in groundwater above background levels. No organic contaminants were detected at levels above their quantitation limits.

\subsubsection{Liquid Waste Disposal System Monitoring Results}

Analytical results from the March, June, and September 1994 groundwater sampling events are presented in the appropriate reports (IT 1994m). Results of the December 1994 sampling are not yet available for this report. TCE was discovered in the LWDS drainfield monitoring well (LWDS-MW1) during December 1993 groundwater sampling. Concentrations were first noted close to the method detection limit (MDL) of 0.005 milligrams per liter $(\mathrm{mg} / \mathrm{L})$, but were confirmed during later sampling at values ranging from $0.010 \mathrm{mg} / \mathrm{L}$ to $0.017 \mathrm{mg} / \mathrm{L}$.

The TCE contamination is now being investigated under the TA-III/V Activity Data Sheet (ADS) because 16 soil borings completed as part of the LWDS investigation have detected no volatile organic contamination at LWDS sites. Several investigations were performed in 1994 to 
evaluate possible sources of TCE in the groundwater. These include interviews with former TA-V staff, completion of passive and active soil gas surveys, an analysis of groundwater recharge, and a geochemical comparison of groundwater quality for wells LWDS-MW1 and LWDS-MW2 (IT 1994m). The investigations indicate a likely source for the TCE contamination inside TA-V, approximately $250 \mathrm{ft}$ south of the LWDS drainfield.

\subsubsection{Technical Area II Groundwater Monitoring Results}

Groundwater sampling at monitoring wells in TA-II detected no chemical contaminants of concern in groundwater from well TA2-W-01 above action levels or MCLs; however, TCE was detected during October 1994 sampling at $0.001 \mathrm{mg} / \mathrm{L}$, which is five times lower than the MCL of $0.005 \mathrm{mg} / \mathrm{L}$. NPN, reported as nitrogen, was detected in well TA2-SW1-320 during all quarterly sampling events, ranging from $22 \mathrm{mg} / \mathrm{L}$ to $26 \mathrm{mg} / \mathrm{L}$; the MCL and MAC for nitrate is $10.0 \mathrm{mg} / \mathrm{L}$. No other chemical contaminants of concern were detected in groundwater from wells TA2-SW1-320 and TA2-NW1-325.

Groundwater samples collected for radionuclide analyses from well TA2-SW1-320 during April and July 1994 detected activities as shown in Table 7-5. Further sampling in 1995 will provide additional data for a more refined analysis of the elevated radionuclide activities. H-3 activities were reported below the DOE guideline for all samples.

Table 7-5. Summary of TA-II Groundwater Radionuclide Analyses

\begin{tabular}{lcccc}
\hline & $\begin{array}{c}\text { Location } \\
\text { (monitoring } \\
\text { well) }\end{array}$ & $\begin{array}{c}\text { Activity } \\
(\mathrm{pCi} / \mathrm{L})\end{array}$ & $\begin{array}{c}\text { DOE Guideline } \\
(\mathrm{pCi} / \mathrm{L})\end{array}$ & Month \\
\hline Parameter & TA2-SW1-320 & 40 & 15 & $04 / 94$ \\
Gross alpha & TA2-SW1-320 & 53 & 15 & $07 / 94$ \\
Gross alpha & TA2-SW1-320 & 45 & 30 & $04 / 94$ \\
Gross beta & TA2-SW1-320 & 52 & 30 & $07 / 94$ \\
Gross beta & Note: DOE-U.S. Department of Energy; pCi/L $=$ picocuries per liter; TA2-SW = \\
\hline Technical Area II-Southwest.
\end{tabular}




\subsection{QUALITY ASSURANCE PROGRAMS}

\subsection{QUALITY ASSURANCE POLICIES AND RESPONSIBILITIES FOR ENVIRONMENTAL PROGRAMS}

The Environmental Operations Center (ENVC) developed and implemented a quality plan that defines a specific approach to ensure that items and services meet the standards set by Sandia National Laboratories/New Mexico (SNL/NM), the U.S. Department of Energy (DOE), and applicable regulatory agencies: the U.S. Environmental Protection Agency (EPA), the Occupational Safety and Health Administration (OSHA), and state and local governments. The ENVC Quality Plan (SNL, in preparation) is being written in accordance with guidelines set forth in DOE Order 5700.6C, Quality Assurance (DOE 1991c), and the SNL Integrated Quality Program (SNL 1993h).

The ENVC Quality Plan describes quality guidelines and standards for all activities and functions conducted by or for the ENVC. This plan stresses prevention of problems by ensuring that (1) requirements are defined in documents such as plans and procedures, (2) requirements are understood through familiarization and training, and (3) activities necessary for fulfilling the requirements are performed by qualified personnel. Ongoing efforts include incorporating applicable quality elements from the ENVC Quality Plan into implementation plans and operating procedures within the departments responsible for hazardous, radioactive, and mixed waste operations, and into environmental protection, remediation, and compliance activities. Each ENVC employee and contractor is responsible for ensuring that all environmentally related activities are performed in accordance with the policies and guidelines set in the ENVC Quality Plan. This plan is in the process of final revision and will be available by the end of fiscal year 1995.

\subsection{QUALITY ASSURANCE OF ENVIRONMENTAL SAMPLING AND ANALYSIS}

This section summarizes quality assurance (QA) activities related to environmental monitoring, remediation, and waste management programs. Sampling is conducted in accordance with program-specific sampling and analysis plans or work plans, each of which contains relevant QA elements. These documents are prepared and implemented in accordance with the ENVC Quality Plan and meet appropriate regulatory guidelines for conducting sampling and analysis activities. QA elements for sampling and analysis follow EPA QA guidelines for activities related to environmental management. QA for sampling and analytical activities performed in support of these programs is discussed in the following subsections.

\subsubsection{Quality Assurance for Sampling Programs}

Quality assurance for sampling activities includes the following:

- The collection of samples using defined sampling procedures.

- The use of sample collection equipment. 
- The selection of sample container decontamination procedures.

- The handling of samples, their preservation, and event documentation procedures.

- The collection of quality control (QC) samples at defined frequencies to estimate sample representativeness and potential contamination acquired during the sampling and handling process.

Before sample collection, specific procedures are prepared to address the mechanics of the process, the location and frequency of samples to be collected, and proper sample preservation and documentation techniques. Sample collection for all programs is performed by trained personnel only, who must complete an analysis request and chain-of-custody form for each sample. Each sample also is assigned a unique control number and documented with a samplecollection $\log$.

Depending on the type of investigation, project-specific QC samples may include trip, equipment, or field blanks, and environmental replicate samples. QC samples are submitted to contractor laboratories in accordance with project-specific data quality objectives (DQOs) and sampling and analysis plans. Replicate environmental samples are collected and submitted to the laboratory to assess the overall variability (precision) of data associated with a particular sampling location. To assess the quality of the sampling process, blank samples are submitted to document the level of contamination contributed by sampling and handling.

\subsubsection{Quality Assurance for Analytical Programs}

Independent analytical laboratories performed most of the chemical analyses of waste and environmental samples collected at SNL/NM in 1994. These laboratories analyzed over 8000 samples, operating under stringent QA plans that comply with the ENVC Quality Plan and applicable EPA requirements and guidelines. Before analytical laboratories are selected, contractor laboratories are appraised in preaward audits in accordance with the ENVC Quality Plan. The selected laboratories are then reappraised annually using inspections and audits, which are filed in the EORC. Table F-1 of Appendix F lists laboratories that provided analytical support to SNL/NM's environmentally related sampling activities in 1994. Information about the quantities and types of samples processed through the ENVC Sample Management Office (SMO) are available in the SMO Sample Tracking Analytical Results (STAR) database.

Analyses employed EPA test procedures wherever possible; otherwise, suitable validated test procedures were used. Instruments were calibrated in accordance with established procedures and the calibration verified before use in an analysis by certified standard reference materials to ensure the accuracy of data generated.

With each SNL/NM samples batch, QC samples were concurrently prepared at defined frequencies and analyzed for each constituent of interest to measure analytical accuracy, precision, contamination, and the matrix effect associated with each analytical measurement. 
For each QC measurement, QC sample results were compared to statistically established control criteria. Analytical results generated concurrent with QC sample results that were within established control limits were considered acceptable. Analytical results generated concurrent with QC sample results that exceeded control limits were considered out of control and corrective action was initiated; reanalysis was performed for all samples in the analytical batch. This process guaranteed the quality of data generated by each analytical laboratory. Results of concurrently analyzed QC sample data were included with each analytical report prepared for SNL/NM which contained sample identification numbers; dates of sample collection, preparation, and analysis; analytical-method reference number; analytes, concentration measured, and detection limit; and associated QC control data.

During 1994, approximately 1000 QC samples were submitted to monitor overall contract laboratory performance. Analyses were performed to comply with SNL/NM QA requirements, to meet project-specific DQOs, and to monitor and document analytical precision and accuracy. Contractor laboratories operate under strict $\mathrm{QA} / \mathrm{QC}$ programs which include periodic participation in the EPA's programs for blind-audit check sampling to monitor the overall precision and accuracy of analyses routinely performed on SNL/NM samples.

To assess the quality of stable chemistry analyses, double-blind samples were submitted along with routine environmental samples to the contractor laboratories at defined frequencies. These check samples were submitted quarterly based on the frequency and type of samples submitted to assess and document laboratory precision and accuracy. All check samples were prepared in batch quantities and subjected to round-robin analyses (multilaboratory analyses of selected analytes to determine a statistical result) to verify analyte concentrations. The samples were prepared by spiking concentrated solutions containing various analytes of interest into reagent-grade water, free of analytical interferents or soil, to create check samples at concentration ranges of one to five times the method detection limit. The check samples were prepared in duplicate to assess analytical precision and accuracy. Check samples submitted to the laboratories consisted of solutions containing trace metals, cyanides, phenolic compounds, and other selected anions, cations, and organic compounds. In addition to aqueous and soil samples, oil samples containing known concentrations of polychlorinated biphenyls (PCBs) were prepared by the EPA and submitted to the laboratories for analysis.

Results of each set of check sample analyses are in Quarterly Performance Evaluation Reports SMO letter reports-to-file and to the laboratories which include average percent recoveries for each suite of samples analyzed and the relative range of actual recoveries and relative percent differences for each analyte tested. A corrective action request was issued for any exceedance of accepted limits. All reports and corrective action responses are filed in the EORC. The resulting data were used to assess each contract laboratory's performance using relative percent difference and percent recovery for respective indicators of precision and accuracy. Review of laboratory performance data generated in 1994 indicated that the majority of analytes tested by the SNL/NM analytical laboratories are within EPA (or interlaboratory, round-robin) prescribed control limits. 
Tables F-2 through F-4 of Appendix F present replicate sampling results in support of the Environmental Monitoring program. Radionuclide analysis results include the mean concentration, standard deviation, and coefficient of variation (CV). The CV is used as a measure of the reproducibility of the data and includes the variation associated with the sampling location and analytical techniques. Replicate samples of water, vegetation, soil, and sediment were collected as a regular part of the Environmental Monitoring program.

The Environmental Monitoring program evaluated its contractor laboratory performance by means of the laboratory's participation in the interlaboratory comparison programs of the EPA Environmental Monitoring Systems Laboratory and the DOE Quality Assessment Program (QAP). Tables F-5 and F-6 of Appendix F show results of the EPA Cross-Check program and the DOE QAP.

\subsubsection{Data Review and Validation}

Sample collection, control documentation, and measurement data were reviewed for each sample collected. Analytical data reported by test laboratories were reviewed for laboratory and field precision and accuracy, completeness, representativeness, and comparability with respect to the DQOs of the particular program. Data were reviewed and validated at a minimum of three levels.

1. By the analytical laboratory, where the data were validated in accordance with the laboratory's QA plan and standard operating procedures.

2. By a knowledgeable member of the SNL/NM SMO staff or by a contractor who reviewed the analytical reports and corresponding sample collection and control documentation for compliance with the following:

- Contract requirements.

- SNL/NM QA requirements.

- Documentation completeness requirements.

- Project-specific data quality requirements.

3. By the SNL/NM project leader responsible for program objectives and regulatory compliance.

Records are maintained on file by the EORC in accordance with ENVC Quality Plan requirements. ENVC also maintains all data files related to this report.

\subsection{CONTRACTOR QUALITY ASSURANCE OVERVIEW}

The SMO has several contractors who provide consulting, waste management and disposal, water sampling and analysis, and other analytical services. These contractors are overseen by 
contract monitors (with support from the ENVC Quality Coordinator) through one of the following mechanisms:

1. Monitoring by task (for consulting services) using a project evaluation sheet to evaluate individual projects. Contractors provide monthly reports on the status of progress and budget.

2. Performance checks and annual on-site appraisals as discussed above (for analytical laboratories). Quarterly blind samples, replicates, and blanks are submitted to the laboratories for performance checks. Corrective actions are documented and implemented.

3. Cost-plus-award-fee contract for hazardous waste management and the Environmental Restoration Project. The contract has a 30-percent fixed and 70-percent variable award fee based on quarterly performance evaluations. 


\subsection{REFERENCES}

CDM 1990: CDM Federal Programs Corporation, "Spill Prevention Control and Countermeasure (SPCC) Plan for Sandia National Laboratories, New Mexico," Plan 90-11, CDM Federal Programs Corporation, Albuquerque, NM (November 1990).

CDM 1993: CDM Federal Programs Corporation, "Spill Prevention Control and Countermeasure (SPCC) Plan for Sandia National Laboratories, New Mexico," Plan 90-11, Revision 1, CDM Federal Programs Corporation, Albuquerque, NM (January 1993).

Culp 1994: Culp, T., SNL/NM Air Quality Department memorandum to F. Ghanbari, "HERMES CAP88 Modeling Results, " Sandia National Laboratories, Albuquerque, NM, (October 31, 1994).

DOC 1992: U.S. Department of Commerce, Bureau of the Census, "1990 United States Census--Preliminary Report," DOC, U.S. Government Printing Office, Washington, DC (1992).

DOE 1987: U.S. Department of Energy Albuquerque Operations Office (DOE/AL), "Comprehensive Environmental Assessment and Response Program Phase 1: Installation Assessment, " draft, DOE/AL, Environment, Safety and Health Division, Albuquerque, NM (September 1987).

DOE 1991a, see Orders section.

DOE 1991b: U.S. Department of Energy, "Environmental Regulatory Guide for Radiological Effluent Monitoring and Environmental Surveillance," DOE/EH-0173T, DOE, Assistant Secretary for Environment, Safety and Health, Washington, DC (January 1991).

DOE 1991c, see Orders section.

DOE 1993a: U.S. Department of Energy, "U.S. DOE Interim Mixed Waste Inventory Report Waste Streams Treatment Capacities and Technologies," DOE/NBM-1100, Volumes 1 through 6, DOE, Washington, DC (April 1993).

DOE 1993b: U.S. Department of Energy, "Nuclear Weapons Complex Reconfiguration Programmatic Environmental Impact Statement (PEIS), " DOE/EIS-0161, DOE, Washington, DC (1993).

DOE 1993c, See Orders section. 
DOE 1994a: U.S. Department of Energy, "Secretary's Policy Statement on the National Environmental Policy Act," DOE, Washington, DC (June 1994).

DOE 1994b: U.S. Department of Energy/Albuquerque Field Office (DOE/AFO), "Neutron Generator/Switch Tube (NG/ST) Prototyping Relocation Environmental Assessment," DOE/EA-0885, DOE/AFO, Albuquerque, NM (April 8, 1994).

DOE 1994c: U.S. Department of Energy/Albuquerque Field Office (DOE/AFO), "Environmental Assessment for the Robotic Manufacturing Science and Engineering Laboratory (RMSEL), " DOE/EA-0879, DOE/AFO, Albuquerque, NM (April 13, 1994).

DOE 1994d: U.S. Department of Energy, "Implementation Plan for Environmental Restoration and Waste Management Programmatic Environmental Impact Statement," DOE/EIS-0200, DOE, Office of Environmental Restoration and Waste Management, Washington, DC (January 1994).

DOE 1995: U.S. Department of Energy/Albuquerque Field Office (DOE/AFO), "General Purpose Heat Source Safety Verification Testing," DOE/EA-1025, DOE/AFO, Albuquerque, NM (February 15, 1995).

EG\&G 1994: Edgerton, Germeschausen \& Grier Corp., "An Aerial Radiological Survey of the Sandia National Laboratories and Surrounding Area I, " EGG 11265-1030; UC-702 (June 1994).

EO, see Orders section.

EPA 1986: U.S. Environmental Protection Agency, "Test Methods for Evaluating Solid Waste, Physical/Chemical Methods, Third Edition," EPASW-846, 2nd ed., U.S. Environmental Protection Agency, Washington, DC (1986).

EPA 1987: U.S. Environmental Protection Agency, "On-Site Meteorological Program Guidance for Regulatory Modeling Applications," EPA, Office of Air Quality Planning and Standards, Research Triangle Park, NC 27711 (June 1987).

EPA 1991: U.S. Environmental Protection Agency, "CAP-88, Clean Air Act Assessment Package," Radiation Shielding Information Center, CCC-542, Oak Ridge, TN (1991).

EPA 1993: U.S. Environmental Protection Agency, "Emission Factors for Diesel Industrial Engines," AP-42, EPA (1993).

ERDA 1977: U.S. Energy Research and Development Administration, "Environmental Impact Assessment, Sandia National Laboratories, Albuquerque, New Mexico," EIA/MA 77-1, ERDA (1977). 
Fink and Park 1992: Fink, C., and E. Park, "Spill Prevention Control and Countermeasure Plan," Plan 90-11, Revision 1, Sandia National Laboratories, Albuquerque, NM (December 14, 1992).

Fink and Park 1993a: Fink, C., and E. Park, "Oil Spill Contingency Plan," Plan 90-11, Revision 1, Sandia National Laboratories, Albuquerque, NM (February 1993).

Fink and Park 1993b: Fink, C., and E. Park, "Hazardous and Radioactive Materials Spill Prevention Control and Countermeasure Plan," draft, Sandia National Laboratories, Albuquerque, NM (1993).

Grant 1982: Grant, P. R., Jr., "Geothermal Potential in the Albuquerque Area, New Mexico," in Guidebook - New Mexico Geological Society, Vol. 33, pp. 325 through 331 (1982).

Gutman and Silver 1994: Gutman, W. M., and R. J. Silver, "Air Quality Investigations of the Sandia National Laboratories Sol se Mete Aerial Cable Facility," SAND93-7094, Sandia National Laboratories, Albuquerque, NM (December 1994).

Hindl et al. 1992: Hindl, S., J. L. Davis, R. E. Barton, and W. A. Rose, "1992 Transportation Service Division Procedures Manual," Sandia National Laboratories, Albuquerque, NM (March 27, 1992).

IT 1994a: IT Corporation, "Former Underground Storage Tank 6587 Onsite Investigation, Technical Area III, Sandia National Laboratories/New Mexico," IT, Albuquerque, NM (March 1994).

IT 1994b: IT Corporation, "Sandia National Laboratories Wastewater Monitoring Program Quarterly Report, November 1993 - January 1994," prepared for Sandia National Laboratories, Albuquerque, NM (1994).

IT 1994c: IT Corporation, "Report on Quarterly Basewide Groundwater Monitoring, December 1993," draft, prepared for the Groundwater Protection Program, Sandia National Laboratories, Albuquerque, NM (1994).

IT 1994d: IT Corporation, "Report on Quarterly Basewide Groundwater Monitoring, March 1994," draft, prepared for the Groundwater Protection Program, Sandia National Laboratories, Albuquerque, NM (1994).

IT 1994e: IT Corporation, "Report on Quarterly Basewide Groundwater Monitoring, June 1994," draft, prepared for the Groundwater Protection Program, Sandia National Laboratories, Albuquerque, NM (1994).

IT 1994f: IT Corporation, "Report on Quarterly Basewide Groundwater Monitoring, September 1994," draft, prepared for the Groundwater Protection Program, Sandia National Laboratories, Albuquerque, NM (1994). 
IT 1994g: IT Corporation, "Report on Annual Groundwater Assessment Monitoring at the Chemical Waste Landfill, Sandia National Laboratories/New Mexico, February 1994," prepared for the Environmental Restoration Project, Sandia National Laboratories, Albuquerque, NM (1994).

IT 1994h: IT Corporation, "Report on Quarterly Groundwater Assessment Monitoring at the Chemical Waste Landfill, Sandia National Laboratories/New Mexico, May 1994," prepared for the Environmental Restoration Project, Sandia National Laboratories, Albuquerque, NM (1994).

IT 1994i: IT Corporation, "Report on Quarterly Groundwater Assessment Monitoring at the Chemical Waste Landfill, Sandia National Laboratories/New Mexico, August 1994," prepared for the Environmental Restoration Project, Sandia National Laboratories, Albuquerque, NM (1994).

IT 1994j: IT Corporation, "Report on Quarterly Groundwater Assessment Monitoring at the Chemical Waste Landfill, Sandia National Laboratories/New Mexico, November 1994," prepared for the Environmental Restoration Project, Sandia National Laboratories, Albuquerque, NM (1994).

IT 1994k: IT Corporation, "Report on Semiannual Groundwater Sampling at the Mixed Waste Landfill, Sandia National Laboratories/New Mexico, March Through May 1994," prepared for the Environmental Restoration Project, Sandia National Laboratories, Albuquerque, NM (1994).

IT 19941: IT Corporation, "Report on Semiannual Groundwater Sampling at the Mixed Waste Landfill, Sandia National Laboratories/New Mexico, October, 1994," prepared for the Environmental Restoration Project, Sandia National Laboratories, Albuquerque, NM (1994).

IT 1994m: IT Corporation, "Analytical Results for Liquid Waste Disposal Site," prepared for the Environmental Restoration Project, Sandia National Laboratories, Albuquerque, NM (1994).

IT 1995: IT Coporation, "Sandia National Laboratories/New Mexico Wastewater Monitoring Report, July 1994-December 1994, " IT, Albuquerque, NM (February 1995).

IT and Consensus Planning 1993: IT Corporation and Consensus Planning, Inc./Zephyr Design, "Sandia National Laboratories, New Mexico Environmental Baseline Update," SAND92-7339, prepared for Sandia National Laboratories, Albuquerque, NM (January 1993).

Kelley 1977: Kelley, V. C., "Geology of Albuquerque Basin, New Mexico," Memoir 33, New Mexico Bureau of Mines and Mineral Resources, Socorro, NM (1977). 
Kelley and Northrup 1975: Kelley, V. C., and S. A. Northrup, "Geology of Sandia Mountains and Vicinity, New Mexico," Memoir 29, New Mexico Bureau of Mines and Mineral Resources, Socorro, NM (1975).

LATA 1991: Los Alamos Technical Associates, "AIRDOS-EPA Data Upgrade and Dose Calculations for SNL, Albuquerque," LATA, Los Alamos, NM (1991) .

Lozinsky et al. 1991: Lozinsky, R. P., J. W. Hawley, and D. W. Lowe, "Geologic Overview and Pliocene-Quaternary History of the Albuquerque Basin, Central New Mexico," Field Guide to Geologic Excursions in New Mexico and Adjacent Areas of Texas and Colorado, Bulletin 37, B. Julian and J. Zidek, editors, New Mexico Bureau of Mines and Mineral Resources, Socorro, NM (1991).

Matise et al. 1994: Matise, B. K., W. M. Gutman, R. A. Cunniff, R. J. Silver, and W. E. Stepp, "Noise and Vibration Investigations of the Sandia National Laboratories Sol se Mete Aerial Cable Facility," SAND93-7095, Sandia National Laboratories, Albuquerque, NM (November 1994).

NAEP 1994: Wolff, T. A., and P. Hansen, 'Use of Comprehensive NEPA Documents to Reduce Program Risk,' in Proceedings of the 1994 National Association of Environmental Professionals (NAEP), "Global Strategies for Environmental Issues," New Orleans, LA, June 12-15, 1994.

NMED 1991: New Mexico Environmental Department, Water Supply Regulations, as Appended Through April 16, 1991, New Mexico Environment Department, Santa Fe, NM (1991).

NMWQR 1991: New Mexico Water Quality Regulations, New Mexico Water Quality Control Commission Regulations (1967, as amended through August 17, 1991).

Radian 1994: Radian Corporation, "Measurement of Tritium and VOC Fluxes from Mixed Waste Landfill at Sandia National Laboratories, New Mexico," Radian Corporation (May 24, 1994).

Secretary of Energy, 1990. "National Environmental Policy Act Notice," SEN-15-90 (February 5, 1990).

SEN-15-90, see Secretary of Energy.

Seylar 1994: Seylar, R. F., "Draft Safety Assessment, Radioactive and Mixed Waste Management Facility, Sandia National Laboratories, New Mexico," Sandia National Laboratories, Albuquerque, NM (March 15, 1994).

Shyr and McClellan 1995: Shyr, L.-J., and Y. McClellan, "Data from Terrestrial Surveillance in CY94," Sandia National Laboratories, Albuquerque, NM (1995). 
Shyr and Skipper 1995: Shyr, L.-J. and B. Skipper, "1994 Environmental Surveillance Data Analysis," Sandia National Laboratories, Albuquerque, NM March (1995).

SNL 1989: Sandia National Laboratories, "Site Development Plan," Sandia National Laboratories, Albuquerque, NM (1989).

SNL 1992a: Sandia National Laboratories, "Chemical Waste Landfill Final Closure Plan and Postclosure Permit Application," Sandia National Laboratories, Albuquerque, NM (December 21, 1992).

SNL 1992b: Sandia National Laboratories, "Final Action Plan to Tiger Team," SAND92-0120, Sandia National Laboratories, Albuquerque, NM (1992).

SNL 1992c: Sandia National Laboratories, "Consolidated Final Action Plan to Tiger Team," SAND92-2035, Sandia National Laboratories, Albuquerque, NM (October 1, 1992).

SNL 1993a: Sandia National Laboratories, "Conceptual Site Treatment Plan for Mixed Waste, "Revision 1 (October 15, 1993), Sandia National Laboratories, Albuquerque, NM (1993).

SNL 1993b: Sandia National Laboratories, "Environment, Safety and Health Training Catalog," MN471010, Sandia National Laboratories, Albuquerque, NM (March 1993).

SNL 1993c: Sandia National Laboratories, "SNL/NM ER Program Quality Assurance Project Plan (QAPP), " Sandia National Laboratories, Albuquerque, NM (March 26, 1993).

SNL 1993d: Sandia National Laboratories, "New Mexico Environment Department Discharge Plan DP-530 Lagoon Discharge Report, Sandia National Laboratories, Albuquerque, Pulsed Power Development Facilities, Technical Area IV, January 1993 through June 1993," submitted by Sandia National Laboratories, Albuquerque, NM, to the New Mexico Environment Department (1993).

SNL 1993e: Sandia National Laboratories, "State of New Mexico Environment Department Discharge Plan DP-530 Lagoon Discharge Report, Sandia National Laboratories, New Mexico, Pulsed Power Development Facilities, Technical Area IV," prepared for Second Semiannual, CY 1993, Sandia National Laboratories, Albuquerque, NM (December 1993).

SNL 1993f: Sandia National Laboratories, "Chemical Waste Landfill Final Closure Plan Approval," Sandia National Laboratories, Albuquerque, NM (February 22, 1993). 
SNL 1993g: Sandia National Laboratories, "Sitewide Groundwater Monitoring Program Sampling and Analysis Plan," draft, Groundwater Monitoring Program, Environmental Restoration Department, Sandia National Laboratories, Albuquerque, New Mexico.

SNL 1993h: Sandia National Laboratories, "Sandia National Laboratories' Integrated Quality Program," SAND93-0891, Sandia National Laboratories, Albuquerque, NM (1993).

SNL 1994a: Sandia National Laboratories, "Internal, Independent ES\&H Appraisal \#94-I-004 Environmental Programmatic Compliance Appraisal," draft report, Sandia National Laboratories, Albuquerque, NM.

SNL 1994b: Sandia National Laboratories, "Program Implementation Plan for Albuquerque Potential Release Sites," Sandia National Laboratories, Albuquerque, NM (February 1994 draft).

SNL 1994c: Sandia National Laboratories, "Sandia National Laboratories Pollution Prevention Plan," Sandia National Laboratories, Albuquerque, NM (May 1994).

SNL 1994d: Sandia National Laboratories, "Quality Assurance Project Plan for Terrestrial Surveillance at Sandia National Laboratories, New Mexico," QUA94-04, Revision 0 Albuquerque, NM (December 1, 1994).

SNL 1994e: Sandia National Laboratories, "NESHAP Radionuclide Compliance Project Summary Report for SNL/NM (HERMES III, HCF, ACRR, SPR III)," SAND942291, Sandia National Laboratories, Albuquerque, NM.

SNL 1994f: Sandia National Laboratories, "Measurement of Ground-Water Level," Field Operating Procedure (FOP) 95-02, Revision 0, Sandia National Laboratories, Albuquerque, NM.

SNL 1994g: Sandia National Laboratories, "Sampling and Analysis Plan for Groundwater Detection Monitoring at the Mixed Waste Landfill," draft, Rev. 1.0, Environmental Restoration Project, Sandia National Laboratories, Albuquerque, NM (1994).

SNL 1994h: Sandia National Laboratories, "Site-Specific Sampling and Analysis Plan, TAII Groundwater Monitoring," Environmental Restoration Project, Sandia National Laboratories, Albuquerque, NM (1994).

SNL 1995a: Sandia National Laboratories, "Sampling and Analysis Plan for Characterization of Waste From Septic System Sampling Project, Sandia National Laboratories, New Mexico," PLA 95-16, Revision 00, Sandia National Laboratories, Albuquerque, NM (May 10, 1995). 
SNL 1995b: Sandia National Laboratories, "Groundwater Protection Program Calendar Year 1994 Annual Groundwater Monitoring Report, Sandia National Laboratories/New Mexico," Sandia National Laboratories, Albuquerque, NM (March 1, 1995).

Szklarz 1995: Szklarz, D. D., "PCB Annual Document Log 1994," Sandia National Laboratories, Albuquerque, NM (May 10, 1995).

Sullivan 1994: Sullivan, R. M., "Biological Investigations of the Sandia National Laboratories Sol se Mete Aerial Cable Facility," SAND93-7093, Sandia National Laboratories, Albuquerque, NM (October 1994).

Sullivan and Knight 1994: Sullivan, R. M., and P. J. Knight, "Biological Surveys for the Sandia National Laboratories Coyote Canyon Complex Kirtland Air Force Base Albuquerque, New Mexico," SAND93-7089, Sandia National Laboratories, Albuquerque, NM (June 1994).

Titus 1963: Titus, F. B., "Geology and Ground-Water Conditions in Eastern Valencia County, New Mexico," Ground-Water Report No. 7, State Bureau of Mines and Mineral Resources, New Mexico Institute of Mining and Technology, Socorro, NM (1963).

U.S. Army Corps of Engineers 1979. "Special Flood Hazard Information, Tijeras Arroyo and Arroyo del Coyote, Kirtland AFB, New Mexico," U.S. Army Corps of Engineers, Albuquerque District, Albuquerque, NM (1979).

Woodward 1982: Woodward, L. A., 'Tectonic Framework of Albuquerque Country,'in "Albuquerque Country II," Guidebook - 33rd New Mexico Geological Society, Field Conference (1982). 


\section{ACTS}

American Indian Religious Freedom Act (AIRFA) of 1978, as amended.

Archaeological Resources Protection Act (ARPA) of 1979, as amended.

Atomic Energy Act of 1954, as amended.

Clean Air Act (CAA) of 1955, as amended. Title 42 U.S.C. 7401.

Clean Water Act (CWA) of 1948, (Federal Water Pollution Control Act), as amended. Title 33 U.S.C. 1251.

Comprehensive Environmental Response, Compensation, and Liability Act (CERCLA) of 1980, as amended. Title 40 U.S.C. 9601.

Emergency Planning and Community Right to Know Act (EPCRA) of 1986 (Enacted by Public Law 99-499, October 17, 1986; 42 U.S.C. 11001 et seq.).

Federal Facility Compliance Act (FFCA) of 1992. Public Law 102-386.

Federal Insecticide, Fungicide, and Rodenticide Act (FIFRA), as amended. Title 7 U.S.C. 136.

National Environmental Policy Act (NEPA) of 1969, as amended. Title 42 U.S.C. 4321 .

National Historic Preservation Act of 1966, as amended, Section 106, Advisory Council on Historic Preservation Comment on Federal Undertakings (16 U.S.C. 470f).

New Mexico Hazardous Waste Act, 1978. New Mexico Statute Amendment \$74-4-1 through 74-4-12, 1978, amended as laws 1983, Chapter 302.

New Mexico Solid Waste Act, Article 9; Enacted by Laws of 1990, Chapter 99; Amended by Laws of 1991, Chapters 185, 194.

Resource Conservation and Recovery Act (RCRA) of 1976. Public Law 94-580, 1976, 90 Statute 2795.

Superfund Amendments and Reauthorization Act (SARA) of 1986. Title III, Section 313, "Toxic Chemical Release Reporting." 
Safe Drinking Water Act (SDWA).

Toxic Substances Control Act (TSCA) of 1976. U.S.C. $\$ 2601$ et seq.

Water Quality Act of 1987. Public Law 100-4, 1987, 100 Statute 7. 


\section{CODE OF FEDERAL REGULATIONS}

10 CFR 835, 1995. "Occupational Radiation Protection," January 1, 1995.

10 CFR 1021, 1992. "National Environmental Policy Act Implementing Procedures," as revised April 24, 1992.

40 CFR 58, 1994. "Protection of Environment," as revised July 1, 1994.

40 CFR 50, 1971. "National Primary and Secondary Ambient Air Quality Standards."

40 CFR 61, 1973. "National Emission Standards for Hazardous Air Pollutants (NESHAP)," including 1985, Subpart H. "National Emission Standards for Emissions of Radionuclide Other Than Radon From Department of Energy Facilities," as amended.

40 CFR 70, 1993. "State Operating Permit Programs."

40 CFR 82, 1988. "Protection of Stratospheric Ozone."

40 CFR 112, 1973. "Oil Pollution Prevention," as amended March 26, 1976.

40 CFR 122, 1980. "EPA Administered Permit Programs: The National Pollutant Discharge Elimination System," as amended November 5, 1991.

40 CFR 123, 1980. "State Program Requirements," as amended November 16, 1990.

40 CFR 124, 1980. "Procedures for Decisionmaking," as amended November 16, 1990.

40 CFR 136, 1973. "Guidelines Establishing Test Procedures for the Analysis of Pollutants," as amended August 15, 1990.

40 CFR 141, 1975. "National Primary Drinking Water Regulations," as amended January $15,1992$.

40 CFR 261, 1980. "Identification and Listing of Hazardous Waste, " as amended January 2, 1992.

40 CFR 262, 1980. "Standards Applicable to Generators of Hazardous Waste," as amended. 
40 CFR 264, 1980. "Standards for Owners and Operators of Hazardous Waste Treatment, Storage, and Disposal Facilities," including Subpart F, Section 264.101, "Releases for Solid Waste Management Units," as amended June 10, 1994.

40 CFR 265, 1980. "Interim Status Standards for Owners and Operators of Hazardous Waste Treatment, Storage, and Disposal Facilities," as amended December 23, 1991.

40 CFR 268, 1986. "Land Disposal Restrictions," as amended August 19, 1991.

40 CFR 280, 1985. "Underground Storage Tanks," as amended December 23, 1991.

40 CFR 281, 1988. "Approval of State Underground Storage Tank Programs," as amended.

40 CFR 372, 1988. "Toxic Chemical Release Reporting: Community Right-to Know," as amended.

40 CFR 413, 1981. "Electroplating Point Source Category," as amended.

40 CFR 433, 1983. "Metal Finishing Point Source Category," as amended.

40 CFR 469, 1983. "Electrical and Electronic Components Point Source Category."

40 CFR 1500 through 1508, 1978. Chapter V, "Council on Environmental Quality." 


\section{ORDERS}

DOE 1988a: U.S. Department of Energy, "General Environmental Protection Program," DOE Order 5400.1, DOE, Washington, DC (1988, change 1, June 21, 1990).

DOE 1988b: U.S. Department of Energy, "Radioactive Waste Management, " DOE Order 5820.2A, DOE, Washington, DC (1988).

DOE 1989a: U.S. Department of Energy, "Comprehensive Environmental Response Compensation and Liability Act Requirements, " DOE Order 5400.4, DOE, Washington, DC (1989).

DOE 1989b: U.S. Department of Energy, "Hazardous and Radioactive Mixed Waste Program," DOE Order 5400.3, DOE, Washington, DC (1989).

DOE 1990a: U.S. Department of Energy, Chapter I, "General Radiological Protection of the Public and the Environment;" Chapter II, "Requirements for Radiation Protection of the Public and the Environment;" and Chapter III, "Derived Concentration Guides for Air and Water," DOE Order 5400.5, DOE, Washington, DC (February 8, 1990, change 2, January 7,1993 ).

DOE 1990b: U.S. Department of Energy, "Conduct of Operations Requirements for DOE Facilities, "DOE Order 5480.19, DOE, Washington, DC (1990, change 1, May 18, 1992).

DOE 1991a: U.S. Department of Energy, "Planning and Preparedness for Operational Emergencies," DOE Order 5500.3A, DOE, Washington, DC (1991, change 1, February 27, 1992).

DOE $1991 \mathrm{~b}$, see main reference section.

DOE 1991c: U.S. Department of Energy, "Quality Assurance," DOE Order 5700.6C, DOE, Washington, DC (August 21, 1991).

DOE 1992a: U.S. Department of Energy, "NEPA Compliance Program," DOE Order 5440.1E, DOE, Washington, DC (1992).

DOE 1992b: U.S. Department of Energy/Albuquerque Operations Office (DOE/AL), "Department of Energy Albuquerque Field Office National Environmental Policy Act Compliance Program," Supplemental Directive AL 5440.1D, DOE/AL, Albuquerque, NM (1992).

DOE 1993a, see main reference section.

DOE 1993b, see main reference section. 
DOE 1993c: U.S. Department of Energy, "Occurrence Reporting and Processing of Operations Information," DOE Order 5000.3B, DOE, Washington, DC (1993, change 1 July 2, 1993).

Executive Order 11988, "Floodplain Management" (Signed May 24, 1977; 42 FR 26951, 3 CFR, 1977 Comp., p. 117; Amended by Executive Order 12148, July 20, 1979; 44 FR 43239, 3 CFR, 1979 Comp., p. 412).

Executive Order 11990, "Protection of Wetlands" (Signed May 24, 1977; 42 FR 26961, 3 CFR, 1977 Comp., p. 121).

Executive Order 12856, "Federal Compliance With Right-to-Know Laws and Pollution Prevention Requirements" (Signed August 3, 1993; 58 FR 41981, August 6, 1993). 


\section{APPENDIX A}

METEOROLOGICAL DATA 
A-2 


\section{CONTENTS}

TABLES

$\underline{\text { Page }}$

A-1 Normals, Means, and Extremes for Albuquerque, New Mexico, 1961 to $1990 \ldots \ldots$. . . . . . . . . . . . . . . . . . . . . . . A

A-2 A21 10-Meter Tower Statistics $\ldots \ldots \ldots \ldots \ldots \ldots \ldots \ldots$ A-6

A-3 SC1 10-Meter Tower Statistics $\ldots \ldots \ldots \ldots \ldots \ldots \ldots \ldots$ A-6

A-4 ST6 60-Meter Tower Statistics $\ldots \ldots \ldots \ldots \ldots \ldots \ldots$ A-7

A-5 CL1 10-Meter Tower Statistics $\ldots \ldots \ldots \ldots \ldots \ldots \ldots \ldots$. . . . . . .

A-6 KU1 10-Meter Tower Statistics $\ldots \ldots \ldots \ldots \ldots \ldots \ldots \ldots \ldots$ A-8

A-7 MW1 10-Meter Tower Statistics $\ldots \ldots \ldots \ldots \ldots \ldots \ldots \ldots$. . . . . .

A-8 A15 50-Meter Tower Statistics $\ldots \ldots \ldots \ldots \ldots \ldots \ldots$. . . . . . . A

A-9 Pasquill-Gifford Stability Classes for the Clean Air Network . . . . . . . . . . . . . . . . . . A-9

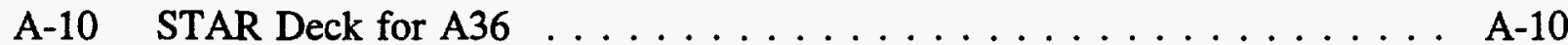

A-11 $\quad \mathbf{P M}_{10}$ Network Analytical Results $\ldots \ldots \ldots \ldots \ldots \ldots \ldots \ldots$ A-14

A-12 Summary of Site-Specific Volatile Organic

Compound Sampling Results $\ldots \ldots \ldots \ldots \ldots \ldots \ldots$ A $\ldots \ldots$

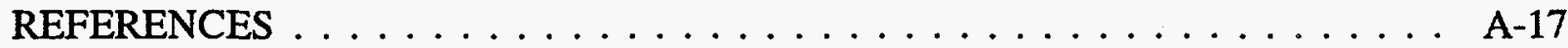


A-4 
Table A-1. Normals, Means, and Extremes for Albuquerque, New Mexico, 1961 to 1990 (NOAA 1990)

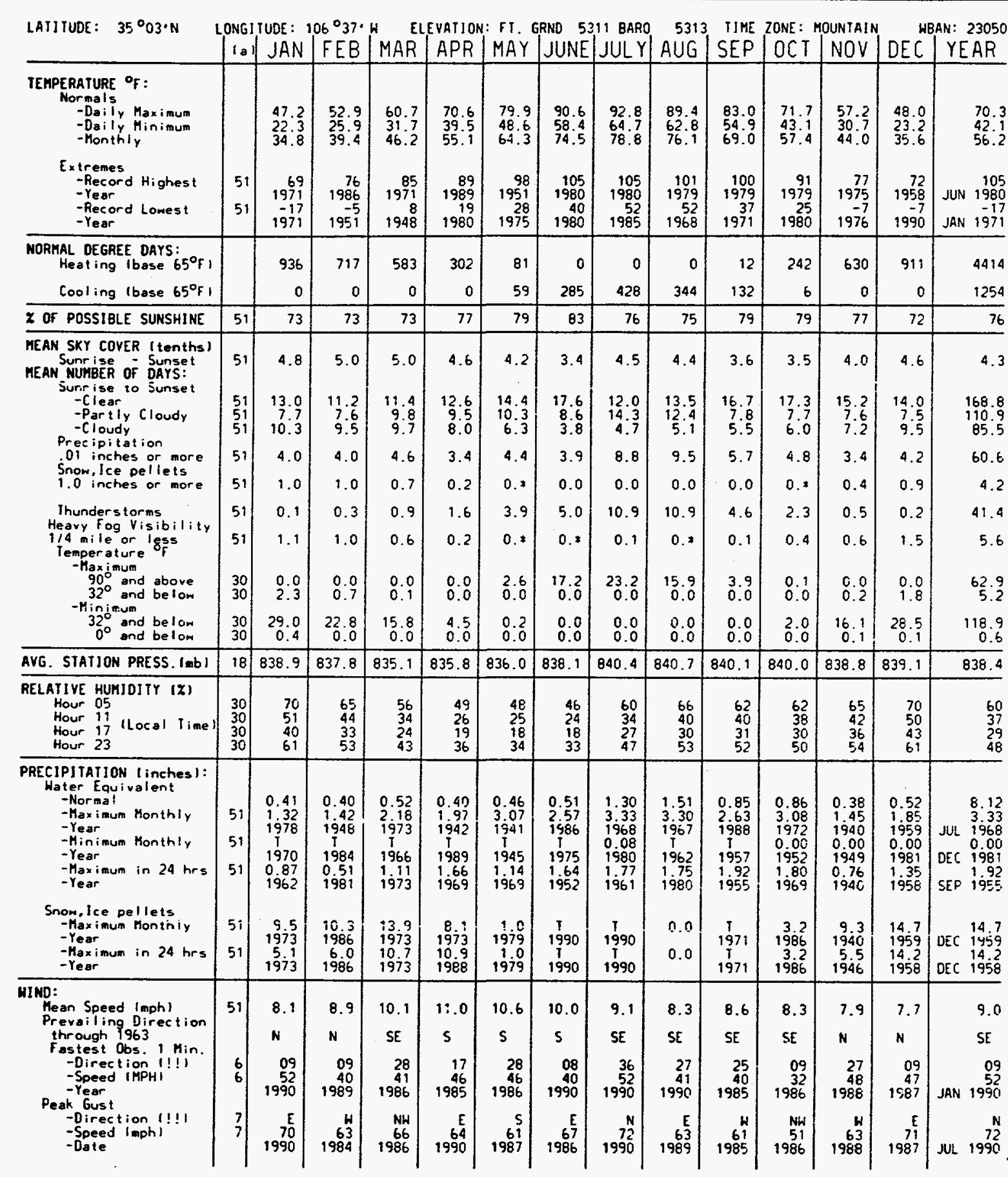

Note:

$\mathrm{T}=$ trace amount. Blank entries denote missing/unreported data. "\#" indicates a station or instrument relocation. (a) = length of record in years, although individual months may be missing. " $0 .{ }^{*}$ " or " *" indicates the value is between 0.0 and 0.05 . Normals are based on the 1961-1990 record period. Extremes dates are the most recent occurrence. Wind direction numerals show tens of degrees clockwise from true north. " 00 " indicates calm. Resultant directions are given to whole degrees. 
Table A-2. A21 10-Meter Tower Statistics

\begin{tabular}{|c|c|c|c|c|c|c|c|c|c|}
\hline Month" & $\begin{array}{c}\text { Average } \\
\text { Temperature } \\
\left({ }^{\circ} \mathrm{C}\right)\end{array}$ & $\begin{array}{c}\text { Maximum } \\
\text { Temperature } \\
\left({ }^{\circ} \mathrm{C}\right)\end{array}$ & $\begin{array}{c}\text { Minimum } \\
\text { Temperature } \\
\left({ }^{\circ} \mathrm{C}\right)\end{array}$ & $\begin{array}{c}\text { Average } \\
\text { RH } \\
(\%)\end{array}$ & $\begin{array}{c}\text { Average } \\
\text { Wind } \\
(\mathrm{m} / \mathrm{s})\end{array}$ & $\begin{array}{l}\text { Maximum } \\
\text { Wind } \\
(\mathrm{m} / \mathrm{s})\end{array}$ & $\begin{array}{l}\text { Average } \\
\text { Rain } \\
\text { (cm) }\end{array}$ & $\begin{array}{l}\text { Maximum } \\
\text { Rain 24-hr } \\
\quad(\mathrm{cm})\end{array}$ & $\begin{array}{c}\text { Pressure } \\
\text { (mb) }\end{array}$ \\
\hline January & 3.3 & 19.5 & -9.8 & 34.0 & 3.5 & 24.5 & 0.03 & 0.03 & 837.0 \\
\hline February (99.9) & 4.4 & 19.3 & -12.5 & 38.0 & 3.4 & 22.1 & 0.61 & 0.38 & 834.5 \\
\hline March & 9.4 & 23.3 & -4.2 & 41.4 & 3.8 & 25.3 & 1.80 & 0.48 & 835.0 \\
\hline April & 13.5 & 27.5 & -2.6 & 30.2 & 4.2 & 22.9 & 0.20 & 0.15 & 833.3 \\
\hline May & 18.5 & 33.3 & 7.0 & 35.8 & 4.2 & 22.1 & 7.42 & 2.34 & 834.2 \\
\hline June (99.7) & 26.3 & 39.1 & 14.0 & 22.2 & 3.7 & 21.3 & 0.25 & 0.13 & 835.5 \\
\hline July & 25.9 & 36.4 & 16.4 & 31.5 & 4.0 & 28.5 & 1.68 & 0.56 & 836.7 \\
\hline August & 24.6 & 35.9 & 15.4 & 43.8 & 3.4 & 25.3 & 10.69 & 4.01 & 838.1 \\
\hline September & 20.3 & 30.8 & 9.3 & 42.1 & 3.1 & 18.1 & 2.54 & 1.14 & 838.2 \\
\hline October & 13.0 & 28.0 & 1.1 & 43.5 & 3.7 & 26.1 & 3.81 & 1.19 & 834.7 \\
\hline November & 6.6 & 21.2 & -6.8 & 47.4 & 3.5 & 22.9 & 3.78 & 1.83 & 834.9 \\
\hline December (99.3) & 3) 4.4 & 14.2 & -7.7 & 52.3 & 2.6 & 16.5 & 1.96 & 0.99 & 836.9 \\
\hline Averages & 14.2 & & & 38.5 & 3.6 & & 34.77 & & 835.7 \\
\hline Extremes & & 39.1 & -12.5 & & & 28.5 & & 4.0 & \\
\hline
\end{tabular}

Note: ${ }^{\circ} \mathrm{C}=$ Celsius degree; $\mathrm{RH}=$ relative humidity (percent); $\mathrm{m} / \mathrm{s}=$ meters per second; $\mathrm{cm}=$ centimeters; $\mathrm{mb}=\mathrm{millibars}$. Monthly data recovery is $100 \%$ except where noted in parentheses.

Table A-3. SC1 10-Meter Tower Statistics

\begin{tabular}{|c|c|c|c|c|c|c|c|c|}
\hline Month ${ }^{*}$ & $\begin{array}{c}\text { Average } \\
\text { Temperature } \\
\left({ }^{\circ} \mathrm{C}\right)\end{array}$ & $\begin{array}{c}\text { Maximum } \\
\text { Temperature } \\
\left({ }^{\circ} \mathrm{C}\right)\end{array}$ & $\begin{array}{c}\text { Minimum } \\
\text { Temperature } \\
\left({ }^{\circ} \mathrm{C}\right)\end{array}$ & $\begin{array}{c}\text { Average } \\
\text { RH } \\
(\%)\end{array}$ & $\begin{array}{l}\text { Average } \\
\text { Wind } \\
(\mathrm{m} / \mathrm{s})\end{array}$ & $\begin{array}{l}\text { Maximum } \\
\text { Wind } \\
(\mathrm{m} / \mathrm{s})\end{array}$ & $\begin{array}{c}\text { Average } \\
\text { Rain } \\
\text { (cm) }\end{array}$ & $\begin{array}{l}\text { Maximum } \\
\text { Rain 24-hr } \\
\text { (cm) }\end{array}$ \\
\hline January & 2.9 & 19.0 & -11.1 & 36.2 & 3.5 & 25.3 & 0.08 & 0.03 \\
\hline February & 4.0 & 18.4 & -10.8 & 40.3 & 3.5 & 23.7 & 0.74 & 0.56 \\
\hline March & 8.8 & 22.3 & -5.7 & 43.8 & 3.9 & 28.5 & 1.78 & 0.61 \\
\hline April & 12.7 & 26.4 & -1.4 & 32.2 & 4.5 & 25.3 & 0.46 & 0.28 \\
\hline May & 17.9 & 32.3 & 5.5 & 37.6 & 4.9 & 24.5 & 8.33 & 2.39 \\
\hline June (97) & 25.4 & 38.4 & 13.1 & 23.9 & 3.9 & 22.1 & 0.56 & 0.46 \\
\hline July (93.2) & 25.1 & 35.8 & 15.2 & 31.9 & 4.4 & 26.1 & 1.65 & 0.61 \\
\hline August & 23.8 & 34.9 & 14.9 & 46.3 & 3.7 & 23.7 & 10.06 & 3.25 \\
\hline September & 19.8 & 29.5 & 7.4 & 44.1 & 3.2 & 19.7 & 2.44 & 1.19 \\
\hline October & 12.6 & 27.1 & -0.2 & 45.0 & 4.0 & 28.5 & 5.61 & 2.84 \\
\hline November & 6.1 & 20.3 & -7.1 & 50.8 & 3.8 & 22.9 & 4.06 & 1.93 \\
\hline December & 4.2 & 14.1 & -9.0 & 55.5 & 2.7 & 18.1 & 2.46 & 1.17 \\
\hline Averages & 13.6 & & & 40.6 & 3.9 & & 37.67 & \\
\hline Extremes & & 38.4 & -11.1 & & & 28.5 & & 3.3 \\
\hline
\end{tabular}


Table A-4. ST6 60-Meter Tower Statistics

\begin{tabular}{|c|c|c|c|c|c|c|}
\hline Month* & $\begin{array}{c}\text { Average } \\
\text { Temperature } \\
\left({ }^{\circ} \mathrm{C}\right)\end{array}$ & $\begin{array}{c}\text { Maximum } \\
\text { Temperature } \\
\left({ }^{\circ} \mathrm{C}\right)\end{array}$ & $\begin{array}{c}\text { Minimum } \\
\text { Temperature } \\
\left({ }^{\circ} \mathrm{C}\right)\end{array}$ & $\begin{array}{l}\text { Average } \\
\text { RH } \\
(\%)\end{array}$ & $\begin{array}{l}\text { Average } \\
\text { Wind } \\
(\mathrm{m} / \mathrm{s})\end{array}$ & $\begin{array}{l}\text { Maximum } \\
\text { Wind } \\
(\mathrm{m} / \mathrm{s})\end{array}$ \\
\hline January (88.3) & 2.6 & 19.4 & -11.1 & 35.4 & 3.7 & 24.5 \\
\hline February & 4.0 & 18.7 & -10.7 & 39.2 & 3.5 & 22.9 \\
\hline March & 9.0 & 23.0 & -5.3 & 42.2 & 3.9 & 23.7 \\
\hline April & 13.0 & 26.9 & -3.0 & 30.7 & 4.3 & 22.9 \\
\hline May & 18.1 & 32.7 & 5.2 & 36.6 & 4.5 & 24.5 \\
\hline June (99.7) & 25.5 & 39.2 & 11.7 & 23.5 & 3.7 & 19.7 \\
\hline July (79.4) & 24.5 & 34.7 & 15.2 & 38.1 & 3.9 & 22.1 \\
\hline August & 24.1 & 34.8 & 14.9 & 45.4 & 3.4 & 50.9 \\
\hline September & 19.7 & 30.8 & 7.7 & 44.3 & 3.2 & 18.9 \\
\hline October & 12.5 & 27.5 & 0.1 & 45.2 & 3.9 & 26.9 \\
\hline November & 6.1 & 20.7 & -7.8 & 50.4 & 3.9 & 21.3 \\
\hline December & 3.9 & 13.9 & -10.3 & 55.7 & 3.0 & 15.7 \\
\hline Averages & 13.6 & & & 40.6 & 3.7 & \\
\hline Extremes & & 39.2 & -11.1 & & & 50.9 \\
\hline
\end{tabular}

Table A-5. CL1 10-Meter Tower Statistics

\begin{tabular}{|c|c|c|c|c|c|c|}
\hline Month* & $\begin{array}{c}\text { Average } \\
\text { Temperature } \\
\left({ }^{\circ} \mathrm{C}\right)\end{array}$ & $\begin{array}{c}\text { Maximum } \\
\text { Temperature } \\
\left({ }^{\circ} \mathrm{C}\right)\end{array}$ & $\begin{array}{c}\text { Minimum } \\
\text { Temperature } \\
\left({ }^{\circ} \mathrm{C}\right)\end{array}$ & $\begin{array}{c}\text { Average } \\
\text { RH } \\
(\%)\end{array}$ & $\begin{array}{l}\text { Average } \\
\text { Wind } \\
(\mathrm{m} / \mathrm{s})\end{array}$ & $\begin{array}{l}\text { Maximum } \\
\text { Wind } \\
(\mathrm{m} / \mathrm{s})\end{array}$ \\
\hline January & 3.1 & 19.6 & -9.8 & 34.6 & 3.4 & 26.9 \\
\hline February & 4.2 & 19.1 & -11.7 & 38.8 & 3.3 & 22.1 \\
\hline March (97.5) & 9.3 & 23.8 & -3.8 & 42.3 & 3.7 & 24.5 \\
\hline April & 13.4 & 27.4 & -4.2 & 30.8 & 4.1 & 21.3 \\
\hline May & 18.4 & 33.6 & 6.9 & 36.7 & 4.2 & 23.7 \\
\hline June (99.8) & 26.1 & 38.9 & 14.1 & 23.1 & 3.5 & 22.1 \\
\hline July (99.9) & 25.8 & 36.7 & 15.3 & 32.6 & 3.8 & 26.1 \\
\hline August & 24.6 & 35.7 & 15.2 & 45.9 & 3.3 & 22.1 \\
\hline September & 20.2 & 30.7 & 8.4 & 44.4 & 2.9 & 18.1 \\
\hline October & 12.9 & 28.1 & 0.9 & 45.2 & 3.6 & 24.5 \\
\hline November & 6.3 & 21.1 & -8.0 & 49.5 & 3.5 & 22.1 \\
\hline December & 4.2 & 14.7 & -7.0 & 53.2 & 2.7 & 14.9 \\
\hline Averages & 14.1 & & & 39.8 & 3.5 & \\
\hline Extremes & & 38.9 & -11.7 & & & 26.9 \\
\hline
\end{tabular}


Table A-6. KU1 10-Meter Tower Statistics

\begin{tabular}{|c|c|c|c|c|c|c|}
\hline Month" & $\begin{array}{c}\text { Average } \\
\text { Temperanure } \\
\left({ }^{\circ} \mathrm{C}\right)\end{array}$ & $\begin{array}{c}\text { Maximum } \\
\text { Temperature } \\
\quad\left({ }^{\circ} \mathrm{C}\right)\end{array}$ & $\begin{array}{c}\text { Minimum } \\
\text { Temperature } \\
\left({ }^{\circ} \mathrm{C}\right)\end{array}$ & $\begin{array}{c}\text { Average } \\
\text { RH } \\
(\%)\end{array}$ & $\begin{array}{l}\text { Average } \\
\text { Wind } \\
(\mathrm{m} / \mathrm{s})\end{array}$ & $\begin{array}{l}\text { Maximum } \\
\text { Wind } \\
(\mathrm{m} / \mathrm{s})\end{array}$ \\
\hline January & 3.2 & 20.0 & -10.4 & 36.7 & 3.4 & 24.5 \\
\hline February & 4.4 & 19.3 & -11.4 & 40.8 & 3.4 & 25.3 \\
\hline March & 9.5 & 23.5 & -4.8 & 43.9 & 3.9 & 23.7 \\
\hline April & 13.4 & 27.3 & -4.0 & 32.0 & 4.3 & 26.1 \\
\hline May & -18.5 & 33.3 & 4.9 & 38.2 & 4.4 & 22.9 \\
\hline June (99.6) & 26.1 & 39.6 & 13.1 & 24.2 & 3.7 & 23.7 \\
\hline July & 25.8 & 37.1 & 15.8 & 32.8 & 4.0 & 26.9 \\
\hline August & 24.6 & 35.4 & 15.1 & 46.7 & 3.3 & 24.5 \\
\hline September & 20.3 & 30.4 & 7.6 & 46.0 & 2.9 & 18.1 \\
\hline October & 13.0 & 28.2 . & 1.7 & 46.9 & 3.6 & 25.3 \\
\hline November & 6.5 & 21.2 & -7.6 & 51.2 & 3.7 & 22.1 \\
\hline December & 4.3 & 15.0 & -8.4 & 55.5 & 2.6 & 16.5 \\
\hline Averages & 14.1 & & & 41.2 & 3.6 & \\
\hline Extremes & & 39.6 & -11.4 & & & 26.9 \\
\hline
\end{tabular}

Table A-7. MW1 10-Meter Tower Statistics

\begin{tabular}{|c|c|c|c|c|c|c|}
\hline Month" & $\begin{array}{c}\text { Average } \\
\text { Temperature } \\
\left({ }^{\circ} \mathrm{C}\right)\end{array}$ & $\begin{array}{l}\text { Maximum } \\
\text { Temperature } \\
\left({ }^{\circ} \mathrm{C}\right)\end{array}$ & $\begin{array}{c}\text { Minimum } \\
\text { Temperature } \\
\left({ }^{\circ} \mathrm{C}\right)\end{array}$ & $\begin{array}{c}\text { Average } \\
\text { RH } \\
(\%)\end{array}$ & $\begin{array}{l}\text { Average } \\
\text { Wind } \\
(\mathrm{m} / \mathrm{s})\end{array}$ & $\begin{array}{c}\text { Maximum } \\
\text { Wind } \\
(\mathrm{m} / \mathrm{s})\end{array}$ \\
\hline January & 3.3 & 19.7 & -10.3 & 38.7 & 3.5 & 23.7 \\
\hline February (96.5) & 4.3 & 18.9 & -11.5 & 42.5 & 3.4 & 22.1 \\
\hline March & 9.5 & 23.6 & -4.7 & 45.1 & 4.0 & 23.7 \\
\hline April & 13.3 & 27.6 & -3.4 & 32.7 & 4.2 & 22.1 \\
\hline May (98.5) & 18.4 & 33.4 & 6.3 & 38.9 & 4.4 & 22.9 \\
\hline June (99.5) & 26.2 & 39.7 & 14.0 & 24.8 & 3.8 & 22.9 \\
\hline July (99.8) & 25.7 & 36.4 & 15.6 & 33.8 & 4.1 & 27.7 \\
\hline August & 24.4 & 36.0 & 14.8 & 48.1 & 3.4 & 25.3 \\
\hline September & 20.2 & 30.5 & 7.8 & 47.7 & 3.0 & 20.5 \\
\hline October & 13.0 & 28.1 & 1.5 & 49.0 & 3.7 & 23.7 \\
\hline November & 6.4 & 21.2 & -7.3 & 53.6 & 3.6 & 22.1 \\
\hline December & 4.4 & 14.1 & -7.6 & 58.6 & 2.7 & 16.5 \\
\hline Averages & 14.1 & & & 42.8 & 3.7 & \\
\hline Extremes & & 39.7 & -11.5 & & & 27.7 \\
\hline
\end{tabular}


Table A-8. A15 50-Meter Tower Statistics

\begin{tabular}{|c|c|c|c|c|c|c|}
\hline Month* & $\begin{array}{c}\text { Average } \\
\text { Temperature } \\
\left({ }^{\circ} \mathrm{C}\right)\end{array}$ & $\begin{array}{c}\text { Maximum } \\
\text { Temperature } \\
\left({ }^{\circ} \mathrm{C}\right)\end{array}$ & $\begin{array}{c}\text { Minimum } \\
\text { Temperature } \\
\left({ }^{\circ} \mathrm{C}\right)\end{array}$ & $\begin{array}{c}\text { Average } \\
\text { RH } \\
(\%)\end{array}$ & $\begin{array}{l}\text { Average } \\
\text { Wind } \\
(\mathrm{m} / \mathrm{s})\end{array}$ & $\begin{array}{c}\text { Maximum } \\
\text { Wind } \\
(\mathrm{m} / \mathrm{s})\end{array}$ \\
\hline June & 25.8 & 37.5 & 16.3 & NA & 2.7 & 26.9 \\
\hline July & 25.7 & 35.3 & 16.1 & NA & 3.1 & 30.9 \\
\hline August & 24.5 & 34.7 & 14.8 & NA & 2.7 & 25.3 \\
\hline September & 20.2 & 30.1 & 9.9 & NA & 2.5 & 21.3 \\
\hline October & 13.0 & 26.9 & 2.0 & NA & 2.9 & 30.1 \\
\hline November & 6.6 & 20.5 & -6.3 & NA & 2.7 & 24.5 \\
\hline December & 4.0 & 13.7 & -6.2 & NA & 2.0 & 17.3 \\
\hline Annual & $\dagger$ & & & NA & 2.7 & \\
\hline Extremes & & 37.5 & -6.3 & & & 30.9 \\
\hline
\end{tabular}

Note: ${ }^{\circ} \mathrm{C}=$ Celsius degree; $\mathrm{RH}=$ relative humidity (percent); $\mathrm{m} / \mathrm{s}=$ meters per second; $\mathrm{NA}=$ not available. *Tower A15 commenced operations June 1, 1994.

${ }^{\dagger}$ Annual average temperature not calculated.

Table A-9. Pasquill-Gifford Stability Classes for the Clean Air Network

\begin{tabular}{crrrrrrr}
\hline $\begin{array}{c}\text { Stability } \\
\text { Class }\end{array}$ & A21 & WM1 & CL1 & ST6 & SC1 & KU1 & A15 \\
\hline A & 14.3 & 13.2 & 15.3 & 12.8 & 12.1 & 13.3 & 25.2 \\
B & 8.6 & 9.1 & 7.4 & 9.4 & 9.7 & 8.9 & 9.2 \\
C & 8.9 & 9.3 & 8.3 & 9.8 & 11.1 & 9.3 & 6.2 \\
D & 44.9 & 38.7 & 44.2 & 48.4 & 39.8 & 39.4 & 23.7 \\
E & 13.8 & 20.5 & 14.8 & 13.6 & 9.9 & 17.8 & 13.3 \\
F & 9.5 & 9.1 & 10 & 5.9 & 17.5 & 11.4 & 22.4 \\
\hline
\end{tabular}


Table A-10. STAR Deck for A36

\begin{tabular}{|c|c|c|c|c|c|}
\hline \multicolumn{6}{|c|}{ Class: A } \\
\hline $\mathrm{N}$ & $1.49 \mathrm{E}-03$ & $0.00 E+\infty$ & $0.00 \mathrm{E}+00$ & $0.00 \mathrm{E}+00$ & $0.00 \mathrm{E}+00$ \\
\hline NNE & $1.37 \mathrm{E}-03$ & $0.00 \mathrm{E}+00$ & $0.00 \mathrm{E}+00$ & $0.00 \mathrm{E}+00$ & $0.00 \mathrm{E}+00$ \\
\hline NE & $1.03 \mathrm{E}-03$ & $0.00 \mathrm{E}+00$ & $0.00 \mathrm{E}+00$ & $0.00 \mathrm{E}+\infty$ & $0.00 \mathrm{E}+00$ \\
\hline ENE & $6.87 \mathrm{E}-04$ & $0.00 \mathrm{E}+00$ & $0.00 \mathrm{E}+00$ & $0.00 \mathrm{E}+00$ & $0.00 \mathrm{E}+00$ \\
\hline $\mathrm{E}$ & $8.01 E-04$ & $0.00 \mathrm{E}+00$ & $0.00 \mathrm{E}+00$ & $0.00 E+00$ & $0.00 \mathrm{E}+\infty 0$ \\
\hline ESE & $2.29 \mathrm{E}-04$ & $0.00 \mathrm{E}+00$ & $0.00 \mathrm{E}+00$ & $0.00 \mathrm{E}+00$ & $0.00 \mathrm{E}+00$ \\
\hline SE & $9.16 \mathrm{E}-04$ & $0.00 \mathrm{E}+00$ & $0.00 \mathrm{E}+00$ & $0.00 \mathrm{E}+00$ & $0.00 \mathrm{E}+00$ \\
\hline SSE & $1.37 \mathrm{E}-03$ & $0.00 \mathrm{E}+00$ & $0.00 \mathrm{E}+00$ & $0.00 \mathrm{E}+00$ & $0.00 \mathrm{E}+00$ \\
\hline $\mathrm{s}$ & $1.49 \mathrm{E}-03$ & $0.00 \mathrm{E}+00$ & $0.00 \mathrm{E}+00$ & $0.00 \mathrm{E}+00$ & $0.00 \mathrm{E}+00$ \\
\hline SSW & $1.95 \mathrm{E}-03$ & $0.00 \mathrm{E}+00$ & $0.00 \mathrm{E}+00$ & $0.00 \mathrm{E}+00$ & $0.00 \mathrm{E}+00$ \\
\hline SW & $2.06 \mathrm{E}-03$ & $0.00 \mathrm{E}+00$ & $0.00 E+00$ & $0.00 \mathrm{E}+00$ & $0.00 \mathrm{E}+00$ \\
\hline wsw & $2.40 \mathrm{E}-03$ & $0.00 \mathrm{E}+00$ & $0.00 \mathrm{E}+00$ & $0.00 \mathrm{E}+00$ & $0.00 \mathrm{E}+00$ \\
\hline W & $3.32 \mathrm{E}-03$ & $0.00 \mathrm{E}+00$ & $0.00 \mathrm{E}+00$ & $0.00 \mathrm{E}+\infty 0$ & $0.00 \mathrm{E}+00$ \\
\hline WNW & $2.63 \mathrm{E}-03$ & $0.00 \mathrm{E}+00$ & $0.00 \mathrm{E}+00$ & $0.00 \mathrm{E}+00$ & $0.00 \mathrm{E}+00$ \\
\hline NW & $1.83 \mathrm{E}-03$ & $0.00 \mathrm{E}+00$ & $0.00 \mathrm{E}+00$ & $0.00 \mathrm{E}+00$ & $0.00 \mathrm{E}+00$ \\
\hline NNW & $2.63 \mathrm{E}-03$ & $0.00 \mathrm{E}+00$ & $0.00 \mathrm{E}+00$ & $0.00 E+00$ & $0.00 \mathrm{E}+\infty$ \\
\hline \multicolumn{6}{|c|}{ Class: $\mathrm{B}$} \\
\hline$N$ & $1.03 \mathrm{E}-03$ & $1.83 \mathrm{E}-03$ & $0.00 \mathrm{E}+00$ & $0.00 \mathrm{E}+00$ & $0.00 \mathrm{E}+00$ \\
\hline NNE & $8.01 \mathrm{E}-04$ & $6.87 \mathrm{E}-04$ & $0.00 \mathrm{E}+00$ & $0.00 \mathrm{E}+00$ & $0.00 \mathrm{E}+00$ \\
\hline $\mathrm{NE}$ & $1.14 \mathrm{E}-04$ & $6.87 \mathrm{E}-04$ & $0.00 \mathrm{E}+00$ & $0.00 \mathrm{E}+00$ & $0.00 \mathrm{E}+00$ \\
\hline ENE & $0.00 \mathrm{E}+00$ & 8.01E-04 & $0.00 \mathrm{E}+00$ & $0.00 \mathrm{E}+00$ & $0.00 \mathrm{E}+00$ \\
\hline E & $1.14 \mathrm{E}-04$ & $1.03 \mathrm{E}-03$ & $0.00 \mathrm{E}+00$ & $0.00 E+00$ & $0.00 \mathrm{E}+00$ \\
\hline ESE & $4.58 \mathrm{E}-04$ & $1.26 \mathrm{E}-03$ & $0.00 \mathrm{E}+00$ & $0.00 E+00$ & $0.00 \mathrm{E}+\infty 0$ \\
\hline $\mathrm{SE}$ & $3.43 \mathrm{E}-04$ & $9.16 \mathrm{E}-04$ & $0.00 \mathrm{E}+00$ & $0.00 \mathrm{E}+00$ & $0.00 \mathrm{E}+00$ \\
\hline SSE & $0.00 \mathrm{E}+00$ & $6.87 \mathrm{E}-04$ & $0.00 E+00$ & $0.00 E+\infty 0$ & $0.00 \mathrm{E}+0$ \\
\hline$s$ & $2.29 \mathrm{E}-04$ & $2.17 \mathrm{E}-03$ & $0.00 \mathrm{E}+00$ & $0.00 \mathrm{E}+00$ & $0.00 \mathrm{E}+00$ \\
\hline ssw & $1.14 \mathrm{E}-04$ & $9.27 \mathrm{E}-03$ & $0.00 \mathrm{E}+00$ & $0.00 \mathrm{E}+00$ & $0.00 E+00$ \\
\hline SW & $3.43 E-04$ & $1.02 \mathrm{E}-02$ & $0.00 \mathrm{E}+00$ & $0.00 \mathrm{E}+00$ & $0.00 \mathrm{E}+00$ \\
\hline
\end{tabular}


Table A-10. STAR Deck for A36 (Continued)

\begin{tabular}{|c|c|c|c|c|c|}
\hline \multicolumn{6}{|c|}{ Class: B (Concluded) } \\
\hline wsw & $2.29 \mathrm{E}-04$ & $5.95 \mathrm{E}-03$ & $0.00 \mathrm{E}+00$ & $0.00 \mathrm{E}+00$ & $0.00 \mathrm{E}+00$ \\
\hline $\mathbf{w}$ & $3.43 \mathrm{E}-04$ & $5.26 \mathrm{E}-03$ & $0.00 \mathrm{E}+00$ & $0.00 \mathrm{E}+00$ & $0.00 \mathrm{E}+00$ \\
\hline WNW & $2.29 \mathrm{E}-04$ & $3.78 \mathrm{E}-03$ & $0.00 \mathrm{E}+00$ & $0.00 \mathrm{E}+00$ & $0.00 \mathrm{E}+00$ \\
\hline NW & 8.01E-04 & $6.52 \mathrm{E}-03$ & $0.00 \mathrm{E}+00$ & $0.00 \mathrm{E}+00$ & $0.00 \mathrm{E}+00$ \\
\hline NNW & $5.72 \mathrm{E}-04$ & $5.49 \mathrm{E}-03$ & $0.00 E+00$ & $0.00 E+00$ & $0.00 \mathrm{E}+00$ \\
\hline \multicolumn{6}{|c|}{ Class: $\mathrm{C}$} \\
\hline $\mathrm{N}$ & $5.72 \mathrm{E}-04$ & $2.40 \mathrm{E}-03$ & $5.72 \mathrm{E}-04$ & $0.00 \mathrm{E}+00$ & $0.00 \mathrm{E}+00$ \\
\hline NNE & $3.43 \mathrm{E}-04$ & $6.87 \mathrm{E}-04$ & $1.14 \mathrm{E}-04$ & $0.00 \mathrm{E}+00$ & $0.00 \mathrm{E}+00$ \\
\hline NE & $1.14 \mathrm{E}-04$ & $6.87 \mathrm{E}-04$ & $2.29 \mathrm{E}-04$ & $0.00 \mathrm{E}+00$ & $0.00 \mathrm{E}+00$ \\
\hline ENE & $3.43 \mathrm{E}-04$ & $9.16 \mathrm{E}-04$ & $1.14 \mathrm{E}-04$ & $0.00 \mathrm{E}+00$ & $0.00 \mathrm{E}+00$ \\
\hline $\mathrm{E}$ & $2.29 \mathrm{E}-04$ & $1.83 \mathrm{E}-03$ & $3.43 \mathrm{E}-04$ & $0.00 \mathrm{E}+00$ & $0.00 \mathrm{E}+00$ \\
\hline ESE & $1.14 \mathrm{E}-04$ & $1.14 \mathrm{E}-03$ & $4.58 \mathrm{E}-04$ & $0.00 \mathrm{E}+00$ & $0.00 \mathrm{E}+00$ \\
\hline SE & $3.43 \mathrm{E}-04$ & $1.83 \mathrm{E}-03$ & $9.16 \mathrm{E}-04$ & $0.00 \mathrm{E}+00$ & $0.00 \mathrm{E}+00$ \\
\hline SSE & $3.43 \mathrm{E}-04$ & $1.26 \mathrm{E}-03$ & $0.00 \mathrm{E}+00$ & $0.00 \mathrm{E}+00$ & $0.00 \mathrm{E}+00$ \\
\hline$s$ & $1.14 \mathrm{E}-04$ & $2.40 \mathrm{E}-03$ & $2.29 \mathrm{E}-04$ & $0.00 \mathrm{E}+00$ & $0.00 \mathrm{E}+00$ \\
\hline ssw & $4.58 \mathrm{E}-04$ & $9.27 \mathrm{E}-03$ & $1.83 \mathrm{E}-03$ & $0.00 \mathrm{E}+00$ & $0.00 \mathrm{E}+00$ \\
\hline sw & $3.43 \mathrm{E}-04$ & $7.10 \mathrm{E}-03$ & $9.16 \mathrm{E}-04$ & $0.00 \mathrm{E}+\infty$ & $0.00 \mathrm{E}+00$ \\
\hline wsw & $0.00 \mathrm{E}+\infty$ & $5.04 \mathrm{E}-03$ & $1.14 \mathrm{E}-03$ & $0.00 \mathrm{E}+00$ & $0.00 \mathrm{E}+00$ \\
\hline w & $4.58 \mathrm{E}-04$ & $4.92 \mathrm{E}-03$ & $1.26 \mathrm{E}-03$ & $0.00 \mathrm{E}+00$ & $0.00 \mathrm{E}+00$ \\
\hline WNW & $2.29 \mathrm{E}-04$ & $2.40 \mathrm{E}-03$ & $1.03 \mathrm{E}-03$ & $0.00 \mathrm{E}+00$ & $0.00 \mathrm{E}+00$ \\
\hline NW & $1.14 \mathrm{E}-04$ & $5.38 \mathrm{E}-03$ & $2.06 \mathrm{E}-03$ & $0.00 \mathrm{E}+00$ & $0.00 \mathrm{E}+00$ \\
\hline NNW & $4.58 \mathrm{E}-04$ & $8.24 \mathrm{E}-03$ & $2.52 \mathrm{E}-03$ & $0.00 \mathrm{E}+00$ & $0.00 \mathrm{E}+00$ \\
\hline \multicolumn{6}{|c|}{ Class: $\mathrm{D}$} \\
\hline$N$ & 8.01E-04 & $9.50 \mathrm{E}-03$ & $4.81 \mathrm{E}-03$ & $2.29 \mathrm{E}-04$ & $0.00 \mathrm{E}+00$ \\
\hline NNE & $2.17 \mathrm{E}-03$ & $5.84 \mathrm{E}-03$ & $3.43 \mathrm{E}-04$ & $1.14 \mathrm{E}-04$ & $0.00 \mathrm{E}+\infty 0$ \\
\hline $\mathrm{NE}$ & $1.72 \mathrm{E}-03$ & $4.69 \mathrm{E}-03$ & $1.26 \mathrm{E}-03$ & $0.00 \mathrm{E}+00$ & $0.00 \mathrm{E}+\infty 0$ \\
\hline ENE & $1.26 \mathrm{E}-03$ & $5.61 \mathrm{E}-03$ & $5.04 \mathrm{E}-03$ & $2.17 \mathrm{E}-03$ & $2.98 \mathrm{E}-03$ \\
\hline E & $1.83 \mathrm{E}-03$ & $7.44 \mathrm{E}-03$ & $2.01 \mathrm{E}-02$ & $1.09 \mathrm{E}-02$ & 4.46E-03 \\
\hline ESE & $1.37 \mathrm{E}-03$ & $9.38 \mathrm{E}-03$ & $1.58 \mathrm{E}-02$ & $5.72 \mathrm{E}-03$ & $3.09 \mathrm{E}-03$ \\
\hline
\end{tabular}


Table A-10. STAR Deck for A36 (Continued)

\begin{tabular}{|c|c|c|c|c|c|}
\hline \multicolumn{6}{|c|}{ Class: D (Concluded) } \\
\hline SE & $1.26 \mathrm{E}-03$ & $1.73 \mathrm{E}-02$ & 4.23E-03 & $1.37 \mathrm{E}-03$ & $0.00 \mathrm{E}+00$ \\
\hline SSE & $6.87 \mathrm{E}-04$ & $1.55 \mathrm{E}-02$ & $2.40 \mathrm{E}-03$ & $1.14 \mathrm{E}-04$ & $1.14 \mathrm{E}-04$ \\
\hline$s$ & $4.58 \mathrm{E}-04$ & $7.90 \mathrm{E}-03$ & $6.29 \mathrm{E}-03$ & $5.15 \mathrm{E}-03$ & $9.16 \mathrm{E}-04$ \\
\hline SSW & $4.58 \mathrm{E}-04$ & $7.90 \mathrm{E}-03$ & $1.19 \mathrm{E}-02$ & $5.38 \mathrm{E}-03$ & $1.72 \mathrm{E}-03$ \\
\hline SW & $2.29 \mathrm{E}-04$ & $5.15 \mathrm{E}-03$ & 3.78E-03 & $9.16 \mathrm{E}-04$ & $4.58 \mathrm{E}-04$ \\
\hline wsw & $4.58 \mathrm{E}-04$ & $3.20 \mathrm{E}-03$ & $4.01 \mathrm{E}-03$ & 1.37E-03 & $6.87 \mathrm{E}-04$ \\
\hline w & $2.29 \mathrm{E}-04$ & $2.63 \mathrm{E}-03$ & $7.78 \mathrm{E}-03$ & $3.20 \mathrm{E}-03$ & $1.37 \mathrm{E}-03$ \\
\hline WNW & $3.43 \mathrm{E}-04$ & $4.12 \mathrm{E}-03$ & $6.98 \mathrm{E}-03$ & $3.20 \mathrm{E}-03$ & 3.43E-04 \\
\hline NW & $2.29 \mathrm{E}-04$ & $4.46 \mathrm{E}-03$ & $6.18 \mathrm{E}-03$ & $2.29 \mathrm{E}-03$ & 3.43E-04 \\
\hline NNW & $1.03 \mathrm{E}-03$ & $8.58 E-03$ & $5.15 \mathrm{E}-03$ & $1.03 \mathrm{E}-03$ & $0.00 \mathrm{E}+00$ \\
\hline \multicolumn{6}{|c|}{ Class: $\mathbf{E}$} \\
\hline$N$ & $2.17 \mathrm{E}-03$ & $1.03 \mathrm{E}-03$ & $0.00 \mathrm{E}+00$ & $0.00 E+00$ & $0.00 \mathrm{E}+00$ \\
\hline NNE & $2.52 \mathrm{E}-03$ & $3.43 \mathrm{E}-04$ & $0.00 \mathrm{E}+\infty 0$ & $0.00 E+00$ & $0.00 \mathrm{E}+00$ \\
\hline NE & $2.52 \mathrm{E}-03$ & $8.01 \mathrm{E}-04$ & $0.00 \mathrm{E}+00$ & $0.00 \mathrm{E}+00$ & $0.00 \mathrm{E}+00$ \\
\hline ENE & $2.29 \mathrm{E}-03$ & 8.01E-04 & $0.00 \mathrm{E}+00$ & $0.00 \mathrm{E}+00$ & $0.00 \mathrm{E}+00$ \\
\hline E & $2.29 \mathrm{E}-03$ & $6.18 \mathrm{E}-03$ & $0.00 \mathrm{E}+00$ & $0.00 E+\infty 0$ & $0.00 \mathrm{E}+00$ \\
\hline ESE & $1.37 \mathrm{E}-03$ & $2.79 \mathrm{E}-02$ & $0.00 \mathrm{E}+\infty 0$ & $0.00 \mathrm{E}+00$ & $0.00 \mathrm{E}+00$ \\
\hline SE & $1.95 \mathrm{E}-03$ & $3.24 \mathrm{E}-02$ & $0.00 \mathrm{E}+00$ & $0.00 \mathrm{E}+00$ & $0.00 \mathrm{E}+00$ \\
\hline SSE & $9.16 \mathrm{E}-04$ & $3.20 \mathrm{E}-03$ & $0.00 \mathrm{E}+00$ & $0.00 \mathrm{E}+00$ & $0.00 \mathrm{E}+00$ \\
\hline $\mathbf{S}$ & $1.37 \mathrm{E}-03$ & $2.17 \mathrm{E}-03$ & $0.00 \mathrm{E}+00$ & $0.00 \mathrm{E}+\infty 0$ & $0.00 \mathrm{E}+00$ \\
\hline SSW & $9.16 \mathrm{E}-04$ & $1.37 \mathrm{E}-03$ & $0.00 \mathrm{E}+00$ & $0.00 E+00$ & $0.00 \mathrm{E}+00$ \\
\hline SW & $4.58 \mathrm{E}-04$ & $5.72 \mathrm{E}-04$ & $0.00 \mathrm{E}+00$ & $0.00 \mathrm{E}+00$ & $0.00 \mathrm{E}+00$ \\
\hline WSW & $6.87 \mathrm{E}-04$ & $1.14 \mathrm{E}-04$ & $0.00 \mathrm{E}+00$ & $0.00 E+\infty$ & $0.00 \mathrm{E}+00$ \\
\hline w & 4.58E-04 & $4.58 \mathrm{E}-04$ & $0.00 E+00$ & $0.00 E+00$ & $0.00 \mathrm{E}+00$ \\
\hline WNW & 8.01E-04 & $4.58 \mathrm{E}-04$ & $0.00 \mathrm{E}+00$ & $0.00 \mathrm{E}+\infty 0$ & $0.00 \mathrm{E}+00$ \\
\hline NW & $8.01 \mathrm{E}-04$ & $1.14 \mathrm{E}-04$ & $0.00 \mathrm{E}+00$ & $0.00 \mathrm{E}+00$ & $0.00 \mathrm{E}+00$ \\
\hline NNW & $9.16 \mathrm{E}-04$ & $0.00 \mathrm{E}+00$ & $0.00 \mathrm{E}+00$ & $0.00 \mathrm{E}+00$ & $0.00 \mathrm{E}+00$ \\
\hline
\end{tabular}


Table A-10. STAR Deck for A36 (Concluded)

\begin{tabular}{rlllll}
\hline & \multicolumn{5}{c}{ Class: $\mathrm{F}$} \\
\hline $\mathrm{N}$ & $3.20 \mathrm{E}-03$ & $0.00 \mathrm{E}+00$ & $0.00 \mathrm{E}+00$ & $0.00 \mathrm{E}+00$ & $0.00 \mathrm{E}+00$ \\
$\mathrm{NNE}$ & $5.95 \mathrm{E}-03$ & $0.00 \mathrm{E}+00$ & $0.00 \mathrm{E}+00$ & $0.00 \mathrm{E}+00$ & $0.00 \mathrm{E}+00$ \\
$\mathrm{NE}$ & $3.20 \mathrm{E}-03$ & $0.00 \mathrm{E}+00$ & $0.00 \mathrm{E}+00$ & $0.00 \mathrm{E}+00$ & $0.00 \mathrm{E}+00$ \\
$\mathrm{ENE}$ & $3.32 \mathrm{E}-03$ & $0.00 \mathrm{E}+00$ & $0.00 \mathrm{E}+00$ & $0.00 \mathrm{E}+00$ & $0.00 \mathrm{E}+00$ \\
$\mathrm{E}$ & $4.01 \mathrm{E}-03$ & $0.00 \mathrm{E}+00$ & $0.00 \mathrm{E}+00$ & $0.00 \mathrm{E}+00$ & $0.00 \mathrm{E}+00$ \\
ESE & $2.63 \mathrm{E}-03$ & $0.00 \mathrm{E}+00$ & $0.00 \mathrm{E}+00$ & $0.00 \mathrm{E}+00$ & $0.00 \mathrm{E}+00$ \\
SE & $2.86 \mathrm{E}-03$ & $0.00 \mathrm{E}+00$ & $0.00 \mathrm{E}+00$ & $0.00 \mathrm{E}+00$ & $0.00 \mathrm{E}+00$ \\
SSE & $3.66 \mathrm{E}-03$ & $0.00 \mathrm{E}+00$ & $0.00 \mathrm{E}+00$ & $0.00 \mathrm{E}+00$ & $0.00 \mathrm{E}+00$ \\
S & $2.75 \mathrm{E}-03$ & $0.00 \mathrm{E}+00$ & $0.00 \mathrm{E}+00$ & $0.00 \mathrm{E}+00$ & $0.00 \mathrm{E}+00$ \\
SSW & $3.43 \mathrm{E}-03$ & $0.00 \mathrm{E}+00$ & $0.00 \mathrm{E}+00$ & $0.00 \mathrm{E}+00$ & $0.00 \mathrm{E}+00$ \\
SW & $2.52 \mathrm{E}-03$ & $0.00 \mathrm{E}+00$ & $0.00 \mathrm{E}+00$ & $0.00 \mathrm{E}+00$ & $0.00 \mathrm{E}+00$ \\
WSW & $2.52 \mathrm{E}-03$ & $0.00 \mathrm{E}+00$ & $0.00 \mathrm{E}+00$ & $0.00 \mathrm{E}+00$ & $0.00 \mathrm{E}+00$ \\
W & $3.09 \mathrm{E}-03$ & $0.00 \mathrm{E}+00$ & $0.00 \mathrm{E}+00$ & $0.00 \mathrm{E}+00$ & $0.00 \mathrm{E}+00$ \\
WNW & $2.75 \mathrm{E}-03$ & $0.00 \mathrm{E}+00$ & $0.00 \mathrm{E}+00$ & $0.00 \mathrm{E}+00$ & $0.00 \mathrm{E}+00$ \\
$\mathrm{NW}$ & $1.83 \mathrm{E}-03$ & $0.00 \mathrm{E}+00$ & $0.00 \mathrm{E}+00$ & $0.00 \mathrm{E}+00$ & $0.00 \mathrm{E}+00$ \\
$\mathrm{NNW}$ & $3.78 \mathrm{E}-03$ & $0.00 \mathrm{E}+00$ & $0.00 \mathrm{E}+00$ & $0.00 \mathrm{E}+00$ & $0.00 \mathrm{E}+00$ \\
\hline
\end{tabular}


Table A-11. $\mathbf{P M}_{10}$ Network Analytical Results

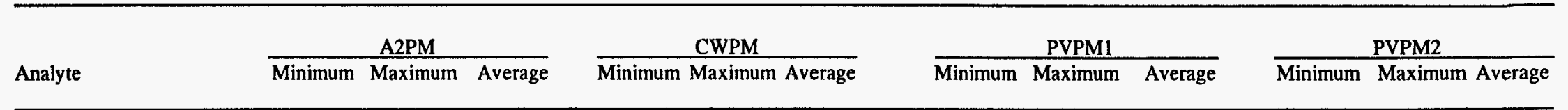

In $\mu \mathrm{g} / \mathrm{m}^{3}:$

\begin{tabular}{|c|c|c|c|c|c|c|c|c|c|c|c|c|}
\hline Arsenic & 0.003 & 0.035 & 0.022 & 0.002 & 0.035 & 0.014 & 0.003 & 0.036 & 0.023 & 0.003 & 0.035 & 0.021 \\
\hline Barium & 0.016 & 0.490 & 0.244 & 0.007 & 0.555 & 0.155 & 0.014 & 0.728 & 0.315 & 0.018 & 0.503 & 0.227 \\
\hline Beryllium & 0.000 & 0.004 & 0.002 & 0.000 & 0.003 & 0.001 & 0.000 & 0.004 & 0.002 & 0.000 & 0.004 & 0.002 \\
\hline Cadmium & 0.000 & 0.007 & 0.003 & 0.000 & 0.006 & 0.002 & 0.000 & 0.009 & 0.004 & 0.000 & 0.010 & 0.004 \\
\hline Chromium & 0.002 & 0.281 & 0.076 & 0.000 & 0.192 & 0.038 & 0.002 & 0.284 & 0.113 & 0.003 & 0.263 & 0.113 \\
\hline Cobalt & 0.000 & 0.007 & 0.003 & 0.000 & 0.007 & 0.002 & 0.001 & 0.012 & 0.004 & 0.000 & 0.007 & 0.004 \\
\hline Copper & 0.018 & 0.103 & 0.046 & 0.010 & 0.048 & 0.025 & 0.011 & 0.057 & 0.029 & 0.015 & 0.053 & 0.033 \\
\hline Iron & 0.149 & 2.053 & 1.127 & 0.099 & 2.073 & 0.756 & 0.137 & 2.448 & 1.231 & 0.164 & 2.349 & 1.092 \\
\hline Lead & 0.005 & 0.061 & 0.029 & 0.002 & 0.062 & 0.019 & 0.003 & 0.289 & 0.052 & 0.004 & 0.078 & 0.043 \\
\hline Manganese & 0.004 & 0.089 & 0.050 & 0.003 & 0.095 & 0.030 & 0.003 & 0.105 & 0.053 & 0.004 & 0.101 & 0.041 \\
\hline Molybdenum & 0.001 & 0.079 & 0.017 & 0.000 & 0.054 & 0.009 & 0.001 & 0.080 & 0.027 & 0.001 & 0.067 & 0.029 \\
\hline Nickel & 0.001 & 0.035 & 0.013 & 0.001 & 0.035 & 0.010 & 0.001 & 0.036 & 0.013 & 0.001 & 0.035 & 0.020 \\
\hline Potassium & 0.759 & 28.496 & 20.193 & 0.699 & 26.456 & 10.532 & 0.726 & 30.743 & 20.523 & 0.763 & 23.025 & 11.271 \\
\hline Selenium & 0.003 & 0.035 & 0.020 & 0.002 & 0.035 & 0.016 & 0.003 & 0.040 & 0.023 & 0.003 & 0.035 & 0.018 \\
\hline Silver & 0.000 & 0.006 & 0.003 & 0.000 & 0.004 & 0.002 & 0.000 & 0.005 & 0.003 & 0.000 & 0.005 & 0.003 \\
\hline Thallium & 0.005 & 0.449 & 0.127 & 0.004 & 0.392 & 0.113 & 0.006 & 0.519 & 0.146 & 0.005 & 0.395 & 0.211 \\
\hline Vanadium & 0.000 & 0.007 & 0.003 & 0.000 & 0.006 & 0.002 & 0.000 & 0.025 & 0.005 & 0.000 & 0.006 & 0.003 \\
\hline Zinc & 0.014 & 0.222 & 0.090 & 0.008 & 0.213 & 0.060 & 0.014 & 0.510 & 0.158 & 0.016 & 0.252 & 0.131 \\
\hline \multicolumn{13}{|l|}{ In $\mathrm{pCi} / \mathrm{m}^{3}$ : } \\
\hline Gross Alpha, total & 0.001 & 0.036 & 0.008 & 0.001 & 0.028 & 0.016 & 0.001 & 0.047 & 0.012 & 0.006 & 0.032 & 0.018 \\
\hline Gross Beta, total & 0.005 & 0.122 & 0.039 & 0.028 & 0.123 & 0.071 & 0.010 & 0.172 & 0.056 & 0.033 & 0.140 & 0.074 \\
\hline Beryllium-7@477 keV & 0.034 & 0.444 & 0.164 & 0.038 & 0.455 & 0.183 & 0.028 & 2.006 & 0.369 & 0.177 & 1.168 & 0.474 \\
\hline Potassium-40@1460 keV & 0.002 & 0.136 & 0.030 & -0.007 & 0.064 & 0.027 & 0.002 & 1.244 & 0.193 & -0.005 & 0.312 & 0.095 \\
\hline \multicolumn{13}{|c|}{ CPMS } \\
\hline Lead (in $\mu \mathrm{g} / \mathrm{m}^{3}$ ) & 0.001 & 0.083 & 0.018 & & & & & & & & & \\
\hline
\end{tabular}


Table A-11. $\mathrm{PM}_{10}$ Network Analytical Results (Concluded)

\begin{tabular}{|c|c|c|c|c|c|c|c|c|c|}
\hline \multirow[b]{2}{*}{ Analyte } & \multicolumn{3}{|c|}{ KUPM } & \multicolumn{3}{|c|}{ MWPME } & \multicolumn{3}{|c|}{ MWPMW } \\
\hline & Minimum & Maxim & $\overline{\text { Average }}$ & Minimum & Maximum & Average & Minimum & Maximum & Average \\
\hline \multicolumn{10}{|l|}{ In $\mu \mathrm{g} / \mathrm{m}^{3}:$} \\
\hline Arsenic & 0.003 & 0.035 & 0.012 & 0.003 & 0.035 & 0.012 & 0.002 & 0.027 & 0.009 \\
\hline Barium & 0.006 & 0.493 & 0.124 & 0.005 & 0.541 & 0.127 & 0.005 & 0.445 & 0.096 \\
\hline Beryllium & 0.000 & 0.042 & 0.004 & 0.000 & 0.003 & 0.001 & 0.000 & 0.003 & 0.001 \\
\hline Cadmium & 0.000 & 0.009 & 0.002 & 0.000 & 0.008 & 0.002 & 0.000 & 0.008 & 0.002 \\
\hline Chromium & 0.002 & 0.307 & 0.054 & 0.002 & 0.297 & 0.051 & 0.001 & 0.225 & 0.039 \\
\hline Cobalt & 0.000 & 0.007 & 0.002 & 0.000 & 0.007 & 0.002 & 0.000 & 0.005 & 0.001 \\
\hline Copper & 0.020 & 0.157 & 0.062 & 0.008 & 0.093 & 0.031 & 0.008 & 0.056 & 0.022 \\
\hline Iron & 0.103 & 2.185 & 0.610 & 0.106 & 2.192 & 0.631 & 0.088 & 1.944 & 0.493 \\
\hline Lead & 0.003 & 0.073 & 0.018 & 0.003 & 0.084 & 0.020 & 0.002 & 0.072 & 0.015 \\
\hline Manganese & 0.003 & 0.095 & 0.026 & 0.003 & 0.096 & 0.024 & 0.003 & 0.082 & 0.020 \\
\hline Molybdenum & 0.001 & 0.078 & 0.014 & 0.001 & 0.079 & 0.013 & 0.000 & 0.056 & 0.009 \\
\hline Nickel & 0.001 & 0.035 & 0.012 & 0.001 & 0.035 & 0.012 & 0.001 & 0.027 & 0.009 \\
\hline Potassium & 0.693 & 25.099 & 8.463 & 0.688 & 24.677 & 7.920 & 0.416 & 15.944 & 5.590 \\
\hline Selenium & 0.003 & 0.035 & 0.014 & 0.003 & 0.035 & 0.013 & 0.002 & 0.027 & 0.010 \\
\hline Silver & 0.000 & 0.006 & 0.002 & 0.000 & 0.006 & 0.002 & 0.000 & 0.005 & 0.001 \\
\hline Thallium & 0.005 & 0.349 & 0.102 & 0.005 & 0.393 & 0.106 & 0.004 & 0.272 & 0.086 \\
\hline Vanadium & 0.000 & 0.006 & 0.002 & 0.000 & 0.006 & 0.002 & 0.000 & 0.005 & 0.002 \\
\hline Zinc & 0.009 & 0.269 & 0.062 & 0.008 & 0.253 & 0.058 & 0.006 & 0.225 & 0.047 \\
\hline Uranium & 0.000 & 0.005 & 0.002 & 0.000 & 0.005 & 0.003 & 0.000 & 0.004 & 0.002 \\
\hline \multicolumn{10}{|l|}{ In $\mathrm{pCi} / \mathrm{m}^{3}$} \\
\hline Gross Alpha & 0.001 & 0.026 & 0.009 & 0.001 & 0.028 & 0.010 & 0.000 & 0.033 & 0.009 \\
\hline Gross Beta & 0.008 & 0.134 & 0.040 & 0.009 & 0.165 & 0.050 & 0.008 & 0.125 & 0.042 \\
\hline Beryllium-7 @477 keV & 0.032 & 0.471 & 0.198 & 0.036 & 0.351 & 0.150 & 0.032 & 0.462 & 0.172 \\
\hline Potassium-40@1460 keV & -0.010 & 0.067 & 0.023 & 0.003 & 0.155 & 0.038 & 0.003 & 0.077 & 0.027 \\
\hline
\end{tabular}


Table A-12. Summary of Site-Specific Volatile Organic Compound Sampling Results (in ppbv)

\begin{tabular}{|c|c|c|c|c|c|c|c|c|c|c|c|c|c|c|c|c|}
\hline Compound & $\mathrm{Obs}^{\dagger}$ & & ange & Average ${ }^{t}$ & Obs & Ran & ge & Average $^{*}$ & Obs & & ange & Average $^{f}$ & Obs & Rar & ge & Iverage $e^{\ddagger}$ \\
\hline Chloromethane & 10 & 0.20 & 0.90 & 0.46 & 8 & 0.30 & 1.70 & 0.58 & 9 & 0.10 & 3.00 & 0.77 & 9 & 0.10 & 1.30 & 0.43 \\
\hline Dichlorodifluoromethane & 10 & 0.30 & 1.10 & 0.60 & 9 & 0.07 & 1.20 & 0.56 & 10 & 0.10 & 1.10 & 0.54 & 9 & 0.30 & 0.90 & 0.52 \\
\hline Isobutene +1 -Butene & 4 & 0.90 & 3.70 & 1.58 & 4 & 0.40 & 2.20 & 1.15 & 1 & 4.60 & 4.60 & 4.60 & 3 & 0.70 & 4.90 & 2.13 \\
\hline n-Butane & 10 & 0.80 & 3.10 & 1.57 & 8 & 0.30 & 2.00 & 0.78 & 9 & 0.20 & 0.60 & 0.39 & 9 & 0.20 & 0.90 & 0.37 \\
\hline Isopentane & 10 & 1.10 & 7.50 & 2.70 & 8 & 0.50 & 16.60 & 3.03 & 9 & 0.30 & 12.60 & 2.00 & 8 & 0.10 & 0.80 & 0.41 \\
\hline Acetone & 8 & 0.50 & 7.90 & 2.33 & 6 & 0.40 & 3.50 & 1.25 & 10 & 0.20 & 27.60 & 6.11 & 7 & 0.40 & 6.00 & 2.26 \\
\hline Trichlorofluoromethane & 10 & 0.10 & 0.40 & 0.22 & 9 & 0.05 & 0.40 & 0.20 & 10 & 0.08 & 0.40 & 0.21 & 10 & 0.07 & 0.40 & 0.18 \\
\hline n-Pentane & 9 & 0.40 & 1.10 & 0.69 & 6 & 0.20 & 1.50 & 0.65 & 6 & 0.20 & 1.10 & 0.38 & 3 & 0.20 & 0.30 & 0.23 \\
\hline Methylene Chloride & 1 & 0.10 & 0.10 & 0.10 & 2 & 0.07 & 0.90 & 0.49 & 1 & 0.09 & 0.09 & 0.09 & 1 & 0.05 & 0.05 & 0.05 \\
\hline Freon 113 & 7 & 0.04 & 0.20 & 0.11 & 5 & 0.05 & 0.20 & 0.10 & 7 & 0.04 & 0.20 & 0.08 & 8 & 0.03 & 0.30 & 0.12 \\
\hline $\begin{array}{l}\text { MTBE, Isohexane, } \\
\text { c4-m2-Pentene }\end{array}$ & 5 & 0.50 & 1.10 & 0.66 & 4 & 0.30 & 0.60 & 0.43 & 3 & 0.20 & 0.60 & 0.37 & 4 & 0.20 & 0.60 & 0.30 \\
\hline 3-Methylpentane & 10 & 0.10 & 0.50 & 0.28 & 3 & 0.10 & 0.30 & 0.20 & 1 & 0.20 & 0.20 & 0.20 & 0 & 0.00 & 0.00 & 0.00 \\
\hline n-Hexane & 10 & 0.10 & 0.50 & 0.27 & 3 & 0.20 & 0.40 & 0.27 & 1 & 0.40 & 0.40 & 0.40 & 0 & 0.00 & 0.00 & 0.00 \\
\hline 1,2-Dichloroethane & 0 & 0.00 & 0.00 & 0.00 & 0 & 0.00 & 0.00 & 0.00 & 0 & 0.00 & 0.00 & 0.00 & 0 & 0.00 & 0.00 & 0.00 \\
\hline 1,1,1-Trichloroethane & 6 & 0.10 & 0.20 & 0.11 & 5 & 0.07 & 0.50 & 0.18 & 6 & 0.06 & 0.60 & 0.23 & 7 & 0.06 & 0.30 & 0.19 \\
\hline Benzene & 10 & 0.40 & 2.00 & 0.78 & 9 & 0.20 & 0.70 & 0.37 & 10 & 0.10 & 0.40 & 0.25 & 10 & 0.10 & 0.40 & 0.25 \\
\hline Carbon Tetrachlori & 6 & 0.08 & 0.09 & 0.08 & 4 & 0.01 & 0.09 & 0.06 & 5 & 0.05 & 0.08 & 0.07 & 5 & 0.03 & 0.09 & 0.07 \\
\hline Trichloroethylene + BDCmethane & 1 & 0.05 & 0.05 & 0.05 & 1 & 0.04 & 0.04 & 0.04 & 1 & 0.20 & 0.20 & 0.20 & 3 & 0.09 & 1.00 & 0.31 \\
\hline 1,4-Dioxane +2,2,4-TMpentane & 8 & 0.20 & 0.40 & 0.24 & 1 & 0.20 & 0.20 & 0.20 & 1 & 0.30 & 0.30 & 0.30 & 2 & 0.20 & 0.40 & 0.30 \\
\hline Toluene & 10 & 0.50 & 1.60 & 0.97 & 8 & 0.20 & 1.00 & 0.48 & 8 & 0.20 & 1.20 & 0.39 & 8 & 0.10 & 0.40 & 0.25 \\
\hline Tetrachloroethylene & 1 & 0.03 & 0.05 & 0.04 & 3 & 0.02 & 0.05 & 0.04 & 1 & 0.03 & 0.03 & 0.03 & 5 & 0.03 & 0.10 & 0.07 \\
\hline Ethylbenzene & 2 & 0.20 & 0.20 & 0.20 & $\mathbf{0}$ & 0.00 & 0.00 & 0.00 & 0 & 0.00 & 0.00 & 0.00 & 0 & 0.00 & 0.00 & 0.00 \\
\hline p-Xylene + m-Xylene & 8 & 0.10 & 0.30 & 0.19 & 2 & 0.20 & 0.20 & 0.20 & 2 & 0.10 & 0.10 & 0.10 & 0 & 0.00 & 0.00 & 0.00 \\
\hline o-Xylene & 3 & 0.10 & 0.10 & 0.10 & $\mathbf{0}$ & 0.00 & 0.00 & 0.00 & $\mathbf{0}$ & 0.00 & 0.00 & 0.00 & 0 & 0.00 & 0.00 & 0.00 \\
\hline n-Undecane & 1 & 0.10 & 0.10 & 0.10 & 1 & 0.00 & 0.00 & 0.00 & $\mathbf{0}$ & 0.00 & 0.00 & 0.00 & 0 & 0.00 & 0.00 & 0.00 \\
\hline TNMHC & 10 & 9.80 & $752 \S$ & $95.45 \mathrm{I}$ & 9 & 3.60 & 24.20 & 9.99 & 10 & 2.40 & 26.60 & 9.79 & 10 & 1.30 & 11.30 & 5.04 \\
\hline
\end{tabular}

Note: $\mathrm{ppbv}=$ parts per billion in volume; TNMHC $=$ total non-methane hydrocarbons.

"Number of samples analyzed in 1994.

tNumber of samples that contained compound at or above the detection limit for that analyte.

${ }^{*}$ Average is calculated using the number of samples in which analyte occurred at or above the detection limit. It is not an annual average.

${ }^{8}$ TNMHC value caused by large concentrations of ethanol and other oxygenated compounds.

I Average skewed from one sample including ethanol and oxygenated compounds. Average without this point is 22.5 ppbv. 


\section{REFERENCE}

NOAA 1990: National Oceanographic and Atmospheric Administration, "Local Climatological Data, Annual Summary with Comparative Data," Albuquerque, NM, NOAA (1990). 


\section{APPENDIX B}

SANDIA NATIONAL LABORATORIES/NEW MEXICO ENVIRONMENTAL RESTORATION PROJECT SITES 
B-2 


\section{CONTENTS}

TABLE

$\underline{\text { Page }}$

B-1 Environmental Restoration Project Sites by Activity

Data Sheet (ADS) Number $\ldots \ldots \ldots \ldots \ldots \ldots \ldots$. . . . . . . . . 
B-4 
Table B-1. Environmental Restoration Project Sites by Activity Data Sheet (ADS) Number

\begin{tabular}{|c|c|c|c|c|}
\hline $\begin{array}{l}\text { ADS No.- } \\
\text { Operable Unit }\end{array}$ & $\begin{array}{l}\text { Site } \\
\text { No. }\end{array}$ & Site Name & $\begin{array}{l}\text { RCRA/RFA } \\
\text { No. }\end{array}$ & Regulatory Driver \\
\hline $\begin{array}{l}\text { 1267-Chemical } \\
\text { Waste Landfill }\end{array}$ & 74 & Chemical Waste Landfill (TA-III) & $\begin{array}{c}1,2,3,4,5,6 \\
7,8,9,20,110\end{array}$ & $\begin{array}{l}40 \text { CFR } 265 \\
\text { Interim Status }\end{array}$ \\
\hline \multirow[t]{2}{*}{$\begin{array}{l}\text { 1281-Kauai Test } \\
\text { Facility }\end{array}$} & $\begin{array}{l}132 \\
133\end{array}$ & $\begin{array}{l}\text { Photographic Laboratory Discharge } \\
\text { Drum Rack Area }\end{array}$ & $\begin{array}{l}\text { None } \\
\text { None }\end{array}$ & $\begin{array}{l}\text { CERCLA } \\
\text { CERCLA }\end{array}$ \\
\hline & 163 & Rocket Launcher Pads & None & CERCLA \\
\hline $\begin{array}{l}\text { 1289-Mixed Waste } \\
\text { Landfill }\end{array}$ & 76 & Mixed Waste Landfill (TA-III) & $\begin{array}{c}24,25,26,27,28,29 \\
30,115,116\end{array}$ & RCRA 3004(u) \\
\hline \multirow[t]{9}{*}{$\begin{array}{l}\text { 1295-Septic Tanks } \\
\text { and Drainfields }\end{array}$} & $\begin{array}{l}49 \\
101\end{array}$ & $\begin{array}{l}\text { Bldg. } 9820 \text { Drains } \\
\text { Explosive Contaminated Sumps, Drains (Bldg. } \\
\text { 9926) }\end{array}$ & $\begin{array}{c}126 \\
\text { None }\end{array}$ & $\begin{array}{l}\text { RCRA 3004(u) } \\
\text { RCRA 3004(u) }\end{array}$ \\
\hline & 138 & Bldg. 6630 Septic System & 79 & RCRA 3004(u) \\
\hline & 139 & Bldg. 9964 Septic System & 79 & RCRA 3004(u) \\
\hline & 140 & Bldg. 9965 Septic System & 79 & RCRA 3004(u) \\
\hline & 141 & Bldg. 9967 Septic System & 79 & RCRA 3004(u) \\
\hline & 142 & Bldg. 9970 Septic System & 79 & RCRA 3004(u) \\
\hline & 143 & Bldg. 9972 Septic System & 79 & RCRA 3004(u) \\
\hline & 144 & Bldg. 9980 Septic System & 79 & RCRA 3004(u) \\
\hline & 145 & Bldg. 9981/9982 Septic Systems & None & RCRA 3004(u) \\
\hline
\end{tabular}


Table B-1. Environmental Restoration Project Sites by Activity Data Sheet (ADS) Number (Continued)

\begin{tabular}{|c|c|c|c|c|}
\hline $\begin{array}{l}\text { ADS No.- } \\
\text { Operable Unit }\end{array}$ & $\begin{array}{l}\text { Site } \\
\text { No. }\end{array}$ & Site Name & $\begin{array}{l}\text { RCRA/RFA } \\
\text { No. }\end{array}$ & Regulatory Driver \\
\hline \multirow{8}{*}{$\begin{array}{l}\text { 1295-Septic Tanks } \\
\text { and Drainfields } \\
\text { (continued) }\end{array}$} & 146 & Bldg. 9920 Drain System & 79 & RCRA 3004(u) \\
\hline & 147 & Bldg, 9925 Septic Systems & 79 & RCRA 3004(u) \\
\hline & 148 & Bldg. 9927 Septic System & 79 & RCRA 3004(u) \\
\hline & 150 & Bldg. 9939/9939A Septic Systems & None & RCRA 3004(u) \\
\hline & 151 & Bldg. 9940 Septic System & 79 & RCRA 3004(u) \\
\hline & 152 & Bldg. 9950 Septic System & 79 & RCRA 3004(u) \\
\hline & 153 & Bldg. 9956 Septic Systems & 79 & RCRA 3004(u) \\
\hline & 154 & Bldg. 9960 Septic Systems & 79 & NM UST Law \\
\hline \multirow{6}{*}{ 1302-Technical Area I } & 30 & $\begin{array}{l}\text { Polychlorinated Biphenyl (PCB) Spill } \\
\text { (Reclamation Yard) }\end{array}$ & $52,53,54, \mathrm{~N}$ & RCRA 3004(u) \\
\hline & 32 & Steam Plant Oil Spill (TA-I) & $\mathbf{P}$ & RCRA 3004(u) \\
\hline & 33 & Motor Pool Oil Spill (TA-I) & $\mathbf{Q}$ & RCRA 3004(u) \\
\hline & 41 & Bldg. 838 Mercury Spill (TA-I) & 0 & RCRA 3004(u) \\
\hline & 42 & Acid Spill Water Treatment Facility (TA-I) & None & RCRA 3004(u) \\
\hline & 73 & $\begin{array}{l}\text { Hazardous Waste Repackaging/ } \\
\text { Storage (Bldg. 895) }\end{array}$ & 105 & RCRA 3004(u) \\
\hline
\end{tabular}


Table B-1. Environmental Restoration Project Sites by Activity Data Sheet (ADS) Number (Continued)

\begin{tabular}{|c|c|c|c|c|}
\hline $\begin{array}{l}\text { ADS No.- } \\
\text { Operable Unit }\end{array}$ & $\begin{array}{l}\text { Site } \\
\text { No. }\end{array}$ & Site Name & $\begin{array}{l}\text { RCRA/RFA } \\
\text { No. }\end{array}$ & Regulatory Driver \\
\hline \multirow{5}{*}{$\begin{array}{l}\text { 1302-Technical Area I } \\
\text { (continued) }\end{array}$} & 96 & Storm Drain System & 113 & RCRA 3004(u) \\
\hline & 98 & $\begin{array}{l}\text { Bldg. 863, 1,1,1-trichloroethane (TCA) } \\
\text { Photochemical Releases: Silver Catch Boxes }\end{array}$ & None & RCRA 3004(u) \\
\hline & 187 & $\begin{array}{l}\text { Septic Tank Piping for Publicly-Owned } \\
\text { Treatment Works (POTW) }\end{array}$ & 80 & RCRA 3004(u) \\
\hline & 190 & Tank Farm for Steam Plant & None & RCRA 3004(u) \\
\hline & 192 & TA-I Waste Oil Tank & None & RCRA 3004(u) \\
\hline \multirow[t]{4}{*}{ 1303-Technical Area II } & 1 & Radioactive Waste Landfill (TA-II) & $\begin{array}{c}32,33,34,35 \\
36,37\end{array}$ & RCRA 3004(u) \\
\hline & 2 & Classified Waste Landfill (TA-II) & 38,39 & RCRA 3004(u) \\
\hline & 3 & Chemical Disposal Pit (TA-II) & 40 & RCRA 3004(u) \\
\hline & 43 & Radioactive Material Storage Yard (TA-II) & 57 & RCRA 3004(u) \\
\hline
\end{tabular}


Table B-1. Environmental Restoration Project Sites by Activity Data Sheet (ADS) Number (Continued)

\begin{tabular}{|c|c|c|c|c|}
\hline $\begin{array}{l}\text { ADS No.- } \\
\text { Operable Unit }\end{array}$ & $\begin{array}{l}\text { Site } \\
\text { No. }\end{array}$ & Site Name & $\begin{array}{l}\text { RCRA/RFA } \\
\text { No. }\end{array}$ & Regulatory Driver \\
\hline \multirow[t]{10}{*}{$\begin{array}{l}\text { 1303-Technical } \\
\text { Area II (continued) }\end{array}$} & 44 & $\begin{array}{l}\text { Decontamination Site and Uranium Calibration Pits } \\
\text { (TA-II) }\end{array}$ & 130 & RCRA 3004(u) \\
\hline & 48 & Bldg. 904 Septic System (TA-II) & 79 & RCRA 3004(u) \\
\hline & 113 & Area II Firing Sites & None & RCRA 3004(u) \\
\hline & 114 & Explosive Burn Pit (TA-II) & None & RCRA 3004(u) \\
\hline & 135 & Bldg. 906 Septic System & 79 & RCRA 3004(u) \\
\hline & 136 & Bldg. 907 Septic System & 79 & RCRA 3004(u) \\
\hline & 159 & Bldg. 935 Septic System & 79 & RCRA 3004(u) \\
\hline & 165 & Bldg. 901 Septic System & 79 & RCRA 3004(u) \\
\hline & 166 & Bldg. 919 Septic System & 79 & RCRA 3004(u) \\
\hline & 167 & Bldg. 940 Septic System & 79 & RCRA 3004(u) \\
\hline \multirow{6}{*}{$\begin{array}{l}\text { 1306-Technical } \\
\text { Areas III and IV }\end{array}$} & 18 & Concrete Pad & 54 & RCRA 3004(u) \\
\hline & 26 & Burial Site (West of TA-III) & None & RCRA 3004(u) \\
\hline & 31 & Electrical Transformer Oil Spill (TA-III) & None & RCRA 3004(u) \\
\hline & 34 & Centrifuge Oil Spill (TA-III) & $\mathbf{R}$ & RCRA 3004(u) \\
\hline & 35 & Vibration Facility Oil Spill (TA-III) & $\mathbf{R}$ & RCRA 3004(u) \\
\hline & 36 & $\begin{array}{l}\text { Oil Spill - High-Energy Radiation Megavolt Electron } \\
\text { Source (HERMES) (TA-V) }\end{array}$ & S & RCRA 3004(u) \\
\hline
\end{tabular}


Table B-1. Environmental Restoration Project Sites by Activity Data Sheet (ADS) Number (Continued)

\begin{tabular}{|c|c|c|c|c|}
\hline $\begin{array}{l}\text { ADS No.- } \\
\text { Operable Unit }\end{array}$ & $\begin{array}{l}\text { Site } \\
\text { No. }\end{array}$ & Site Name & $\begin{array}{l}\text { RCRA/RFA } \\
\text { No. }\end{array}$ & Regulatory Driver \\
\hline \multirow{14}{*}{$\begin{array}{l}\text { 1306-Technical } \\
\text { Areas III and IV } \\
\text { (continued) }\end{array}$} & 37 & Proto Oil Spill (TA-V) & $\mathrm{T}$ & RCRA 3004(u) \\
\hline & 51 & Bldg. 6924 Pad, Tank, Pit & 10,11 & RCRA 3004(u) \\
\hline & 78 & Gas Cylinder Disposal Pit (TA-III) & 31 & RCRA 3004(u) \\
\hline & 83 & Long Sled Track (TA-III) & I & RCRA 3004(u) \\
\hline & 84 & Gun Facilities (TA-III) & None & RCRA 3004(u) \\
\hline & 100 & $\begin{array}{l}\text { Bldg. } 6620 \text { High Explosives (HE) } \\
\text { Sump/Drain (TA-III) }\end{array}$ & 84,85 & RCRA 3004(u) \\
\hline & 102 & Radioactive Disposal (east of TA-III) & None & RCRA 3004(u) \\
\hline & 105 & Mercury (Bldg. 6536) (TA-III) & None & RCRA 3004(u) \\
\hline & 107 & Explosive Test Area (southeast TA-III) & None & RCRA 3004(u) \\
\hline & 111 & Bldg. 6715 Sump/Drains (TA-III) & 79 & RCRA 3004(u) \\
\hline & 188 & $\begin{array}{l}\text { Bldg. } 6597 \text { Aboveground Containment } \\
\text { Spill Tank (TA-V) }\end{array}$ & 99 & RCRA 3004(u) \\
\hline & 196 & Bldg. 6597 Cistern (TA-V) & None & RCRA 3004(u) \\
\hline & 240 & Short Sled Track & None & RCRA 3004(u) \\
\hline & 241 & Storage Yard & None & RCRA 3004(u) \\
\hline \multirow{2}{*}{$\begin{array}{l}\text { 1307-Liquid Waste } \\
\text { Disposal System } \\
\text { (LWDS) }\end{array}$} & 4 & LWDS Surface Impoundments & 18,19 & RCRA 3004(u) \\
\hline & 5 & LWDS Drainfield (TA-V) & 16,17 & RCRA 3004(u) \\
\hline
\end{tabular}


Table B-1. Environmental Restoration Project Sites by Activity Data Sheet (ADS) Number (Continued)

\begin{tabular}{|c|c|c|c|c|}
\hline $\begin{array}{l}\text { ADS No.- } \\
\text { Operable Unit }\end{array}$ & $\begin{array}{l}\text { Site } \\
\text { No. }\end{array}$ & Site Name & $\begin{array}{l}\text { RCRA/RFA } \\
\text { No. }\end{array}$ & Regulatory Driver \\
\hline $\begin{array}{l}\text { 1307-Liquid Waste } \\
\text { Disposal System } \\
\text { (LWDS) (continued) }\end{array}$ & 52 & LWDS Holding Tanks (TA-V) & 135 & RCRA 3004(u) \\
\hline \multirow[t]{15}{*}{ 1309-Tijeras Arroyo } & 7 & $\begin{array}{l}\text { Gas Cylinder Disposal (Arroyo del } \\
\text { Coyote) }\end{array}$ & 44 & RCRA 3004(u) \\
\hline & 16 & Open Dumps (Arroyo del Coyote) & 21,55 & RCRA 3004(u) \\
\hline & 23 & Disposal Trenches (near Tijeras Arroyo) & $47,48,49$ & RCRA 3004(u) \\
\hline & 40 & Oil Spill (6000 Igloo Area) & W & RCRA 3004(u) \\
\hline & 45 & Liquid Discharge (behind TA-IV) & None & RCRA 3004(u) \\
\hline & 46 & Old Acid Waste Line Outfall (Tijeras Arroyo) & 112 & RCRA 3004(u) \\
\hline & 50 & Old Centrifuge Site (Tijeras Arroyo) & None & RCRA 3004(u) \\
\hline & 77 & Oil Surface Impoundment (Tijeras Arroyo) & $12,81,82$ & RCRA 3004(u) \\
\hline & 227 & Bunker 904 Outfall (Tijeras Arroyo) & None & RCRA 3004(u) \\
\hline & 228 & Centrifuge Dump Site & None & RCRA 3004(u) \\
\hline & 229 & Storm Drain System Outfall & None & RCRA 3004(u) \\
\hline & 230 & Storm Drain System Outfall & None & RCRA 3004(u) \\
\hline & 231 & Storm Drain System Outfall & None & RCRA 3004(u) \\
\hline & 232 & Storm Drain System Outfall & None & RCRA 3004(u) \\
\hline & 233 & Storm Drain System Outfall & None & RCRA 3004(u) \\
\hline
\end{tabular}


Table B-1. Environmental Restoration Project Sites by Activity Data Sheet (ADS) Number (Continued)

\begin{tabular}{|c|c|c|c|c|}
\hline $\begin{array}{l}\text { ADS No.- } \\
\text { Operable Unit }\end{array}$ & $\begin{array}{l}\text { Site } \\
\text { No. }\end{array}$ & Site Name & $\begin{array}{l}\text { RCRA/RFA } \\
\text { No. }\end{array}$ & Regulatory Driver \\
\hline \multirow{2}{*}{$\begin{array}{l}\text { 1309-Tijeras Arroyo } \\
\text { (continued) }\end{array}$} & 234 & Storm Drain System Outfall & None & RCRA 3004(u) \\
\hline & 235 & Storm Drain System Outfall & None & RCRA 3004(u) \\
\hline \multirow{4}{*}{$\begin{array}{l}\text { 1332-Foothills } \\
\text { Test Area }\end{array}$} & 19 & $\begin{array}{l}\text { Transuranic Package Transporter (TRUPACT) } \\
\text { Boneyard Storage Area (northwest of Old Aerial } \\
\text { Cable) }\end{array}$ & 65 & RCRA 3004(u) \\
\hline & 27 & Bldg. 9820 - Animal Disposal Pit (Coyote Springs) & 42 & RCRA 3004(u) \\
\hline & 28 & Mine Shafts & None & RCRA 3004(u) \\
\hline & 87 & Bldg. 9990 (Firing Site) & $108, \mathrm{D}$ & RCRA 3004(u) \\
\hline \multirow[t]{4}{*}{$\begin{array}{l}\text { 1333-Canyons Test } \\
\text { Area }\end{array}$} & 10 & $\begin{array}{l}\text { Burial Mounds (Bunker Area north of Pendulum } \\
\text { Site) }\end{array}$ & $60,61,62,63$ & RCRA 3004(u) \\
\hline & 12 & Burial Site/Open Dump (Lurance Canyon) & 41 & RCRA 3004(u) \\
\hline & 13 & $\begin{array}{l}\text { Oil Surface Impoundment (Lurance Canyon Burn } \\
\text { Site) }\end{array}$ & 13 & RCRA 3004(u) \\
\hline & 59 & Pendulum Site & None & RCRA 3004(u) \\
\hline
\end{tabular}


Table B-1. Environmental Restoration Project Sites by Activity Data Sheet (ADS) Number (Continued)

\begin{tabular}{|c|c|c|c|c|}
\hline $\begin{array}{l}\text { ADS No.- } \\
\text { Operable Unit }\end{array}$ & $\begin{array}{l}\text { Site } \\
\text { No. }\end{array}$ & Site Name & $\begin{array}{c}\text { RCRA/RFA } \\
\text { No. }\end{array}$ & Regulatory Driver \\
\hline \multirow{14}{*}{$\begin{array}{l}\text { 1333-Canyons Test } \\
\text { Area (continued) }\end{array}$} & 60 & Bunker Area (north of Pendulum Site) & 124 & RCRA 3004(u) \\
\hline & 63 & Balloon Test Area & E1 & RCRA 3004(u) \\
\hline & 64 & Gun Site (Madera Canyon) & E2 & RCRA 3004(u) \\
\hline & 65 & Lurance Canyon Explosive Test Site & None & RCRA 3004(u) \\
\hline & 72 & Operation Beaver Site & None & RCRA 3004(u) \\
\hline & 81 & $\begin{array}{l}\text { New Aerial Cable Site/Burial } \\
\text { Site/Dump/Test Area }\end{array}$ & $22,50,51,59$ & RCRA 3004(u) \\
\hline & 92 & $\begin{array}{l}\text { Pressure Vessel Test Site (Coyote Canyon } \\
\text { Blast Area) }\end{array}$ & 64 & RCRA 3004(u) \\
\hline & 93 & Madera Canyon Rocket Launcher Pads & E3 & RCRA 3004(u) \\
\hline & 94 & Lurance Canyon Burn Site & 119 & RCRA 3004(u) \\
\hline & 225 & $\begin{array}{l}\text { Atomic Energy Commission (AEC) Storage } \\
\text { Facility/Kirtland Air Force Base (KAFB) }\end{array}$ & None & RCRA 3004(u) \\
\hline & 236 & Pit East of Balloon Site & None & RCRA 3004(u) \\
\hline & 237 & Rocket Launch Rail & None & RCRA 3004(u) \\
\hline & 238 & Rocket Launch Rail Impact Area & None & RCRA 3004(u) \\
\hline & 239 & Impact Area $155-\mathrm{mm}$ and Rockets & None & RCRA 3004(u) \\
\hline \multirow{3}{*}{$\begin{array}{l}\text { 1334-Central } \\
\text { Coyote Test Area }\end{array}$} & 9 & Burial Site/Open Dump (Schoolhouse Mesa) & 43 & RCRA 3004(u) \\
\hline & 11 & Explosive Burial Mounds & $68,69,70$ & RCRA 3004(u) \\
\hline & 20 & Schoolhouse Mesa Burn Site & None & RCRA 3004(u) \\
\hline
\end{tabular}


Table B-1. Environmental Restoration Project Sites by Activity Data Sheet (ADS) Number (Continued)

\begin{tabular}{|c|c|c|c|c|}
\hline $\begin{array}{l}\text { ADS No.- } \\
\text { Operable Unit }\end{array}$ & $\begin{array}{l}\text { Site } \\
\text { No. }\end{array}$ & Site Name & $\begin{array}{l}\text { RCRA/RFA } \\
\text { No. }\end{array}$ & Regulatory Driver \\
\hline \multirow{15}{*}{$\begin{array}{l}\text { 1334-Central Coyote } \\
\text { Test Area (continued) }\end{array}$} & 21 & Metal Scrap (Coyote Springs) & 73 & RCRA 3004(u) \\
\hline & 22 & Storage/Burn (West of DEER) & 106 & RCRA 3004(u) \\
\hline & 47 & Unmanned Seismic Observatory & 133,134 & RCRA 3004(u) \\
\hline & $57 \mathrm{~A}$ & Workman Site: Firing Site & $\mathbf{G}$ & RCRA 3004(u) \\
\hline & $57 \mathrm{~B}$ & Workman Site: Target Area & G & RCRA 3004(u) \\
\hline & $61 \mathrm{~A}$ & Schoolhouse Mesa Test Site: Blast Area & None & RCRA 3004(u) \\
\hline & $61 B$ & Schoolhouse Mesa Test Site: Cratering Area & None & RCRA 3004(u) \\
\hline & $61 \mathrm{C}$ & Schoolhouse Mesa Test Site: Schoolhouse BIdg. & None & RCRA 3004(u) \\
\hline & 62 & Graystone Manor Site (Coyote Springs) & None & RCRA 3004(u) \\
\hline & 68 & Old Burn Site & 111 & RCRA 3004(u) \\
\hline & 69 & Old Borrow Pit & None & RCRA 3004(u) \\
\hline & 70 & Explosives Test Pit (Water Towers) & 127 & RCRA 3004(u) \\
\hline & 71 & Moonlight Shot Area & $\mathbf{F}$ & RCRA 3004(u) \\
\hline & $88 \mathrm{~A}$ & Firing Site: Ranchhouse & $\mathbf{J}$ & RCRA 3004(u) \\
\hline & 88B & Firing Site: Instrumentation Pole & $\mathbf{J}$ & RCRA 3004(u) \\
\hline \multirow{2}{*}{$\begin{array}{l}\text { 1335-Southwest } \\
\text { Test Area }\end{array}$} & 6 & Gas Cylinder Disposal Pit (Bldg. 9966) & $72, \mathrm{~L}$ & RCRA 3004(u) \\
\hline & 14 & Burial Site (Bldg. 9920) & 45 & RCRA 3004(u) \\
\hline
\end{tabular}


Table B-1. Environmental Restoration Project Sites by Activity Data Sheet (ADS) Number (Continued)

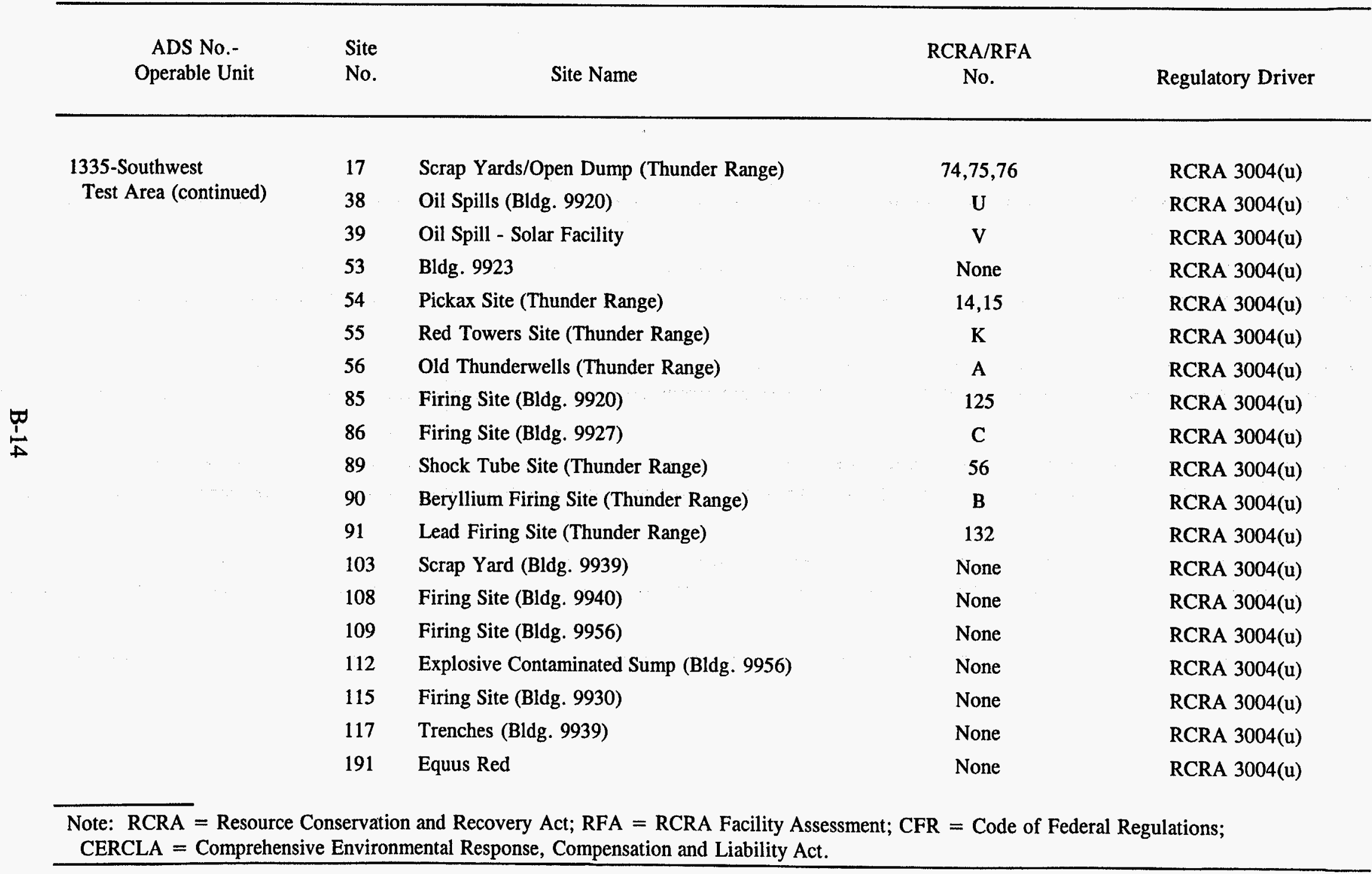


Table B-1. Environmental Restoration Project Sites by Activity Data Sheet (ADS) Number (Continued)

\begin{tabular}{|c|c|c|c|c|}
\hline $\begin{array}{l}\text { ADS No.- } \\
\text { Operable Unit }\end{array}$ & $\begin{array}{l}\text { Site } \\
\text { No. }\end{array}$ & Site Name & $\begin{array}{l}\text { RCRA/RFA } \\
\text { No. }\end{array}$ & Regulatory Driver \\
\hline \multirow{3}{*}{$\begin{array}{l}\text { 1335-Southwest } \\
\text { Test Area (continued) }\end{array}$} & 193 & Sabotage Test Area & None & RCRA 3004(u) \\
\hline & 194 & General Purpose Heat Source Test Area & None & RCRA 3004(u) \\
\hline & 242 & Sabotage Test Box (Thunder Range) & None & RCRA 3004(u) \\
\hline $\begin{array}{l}\text { 1336-Salton Sea } \\
\text { Test Base }\end{array}$ & 157 & Salton Sea Test Base & None & CERCLA \\
\hline \multirow{9}{*}{$\begin{array}{l}\text { 1337-Off-Site } \\
\text { Areas }\end{array}$} & 156 & Pagano Salvage Yard & None & CERCLA - NPL \\
\hline & 164 & Edgewood Test Site & None & CERCLA \\
\hline & 184 & Holloman AFB Bldg. 882-1 Septic System & None & CERCLA \\
\hline & 199 & AEC Storage Facility/Fort Hood, TX & None & CERCLA \\
\hline & 200 & AEC Storage Facility/Fort Campbell, KY & None & CERCLA/RCRA \\
\hline & 201 & AEC Storage Facility/Barksdale AFB, LA & None & CERCLA \\
\hline & 202 & AEC Storage Facility/Loring AFB, ME & None & CERCLA \\
\hline & 203 & AEC Storage Facility/Ellsworth AFB, SD & None & CERCLA \\
\hline & 204 & AEC Storage Facility/Fairchild AFB, WA & None & CERCLA \\
\hline
\end{tabular}


Table B-1. Environmental Restoration Project Sites by Activity Data Sheet (ADS) Number (Continued)

\begin{tabular}{|c|c|c|c|c|}
\hline $\begin{array}{l}\text { ADS No.- } \\
\text { Operable Unit }\end{array}$ & $\begin{array}{l}\text { Site } \\
\text { No. }\end{array}$ & Site Name & $\begin{array}{c}\text { RCRA/RFA } \\
\text { No. }\end{array}$ & Regulatory Driver \\
\hline \multirow[t]{15}{*}{$\begin{array}{l}\text { 1337-Off-Site } \\
\text { Areas (Continued) }\end{array}$} & 205 & $\begin{array}{l}\text { AEC Storage Facility/ } \\
\text { Travis AFB, CA }\end{array}$ & None & CERCLA \\
\hline & 206 & $\begin{array}{l}\text { AEC Storage Facility/ } \\
\text { Westover AFB, MA }\end{array}$ & None & CERCLA \\
\hline & 207 & $\begin{array}{l}\text { AEC Storage Facility/Yorktown } \\
\text { Naval Weapons Station, VA }\end{array}$ & None & CERCLA \\
\hline & 208 & $\begin{array}{l}\text { AEC Storage Facility/ } \\
\text { Lackland AFB, TX }\end{array}$ & None & CERCLA \\
\hline & 209 & $\begin{array}{l}\text { AEC Storage Facility/ } \\
\text { Nellis AFB, NV }\end{array}$ & None & CERCLA \\
\hline & 210 & $\begin{array}{l}\text { AEC Storage Facility/Seneca } \\
\text { Army Depot, NY }\end{array}$ & None & CERCLA/RCRA \\
\hline & 243 & Los Lunas Bombing Range, NM & None & CERCLA \\
\hline & 244 & Bernardo Test Site, NM & None & CERCLA \\
\hline & 245 & New Site & None & CERCLA \\
\hline & 246 & New Site & None & CERCLA \\
\hline & 247 & New Site & None & CERCLA \\
\hline & 248 & New Site & None & CERCLA \\
\hline & 249 & New Site & None & CERCLA \\
\hline & 250 & New Site & None & CERCLA \\
\hline & 251 & New Site & None & CERCLA \\
\hline
\end{tabular}


Table B-1. Environmental Restoration Project Sites by Activity Data Sheet (ADS) Number (Continued)

\begin{tabular}{|c|c|c|c|c|}
\hline $\begin{array}{l}\text { ADS No.- } \\
\text { Operable Unit }\end{array}$ & $\begin{array}{l}\text { Site } \\
\text { No. }\end{array}$ & Site Name & $\begin{array}{l}\text { CRA/RF } \\
\text { No. }\end{array}$ & Regulatory Driver \\
\hline $\begin{array}{l}\text { 1337-Off-Site } \\
\text { Areas (continued) }\end{array}$ & 252 & New Site & None & CERCLA \\
\hline $\begin{array}{l}\text { DOE/AL Resp.- } \\
\text { Responsibility of Others }\end{array}$ & 95 & $\begin{array}{l}\text { Live Fire Range (Central } \\
\text { Training Academy) }\end{array}$ & None & RCRA 3004(u) \\
\hline \multirow{12}{*}{$\begin{array}{l}\text { DOE/NVO Resp.- } \\
\text { Responsibility of Others }\end{array}$} & 118 & Underground Diesel Tank (Tonopah Test Range [TTR]) & None & CERCLA \\
\hline & 119 & Area 3 Landfills (TTR) & None & CERCLA \\
\hline & 120 & Fire Training Area (TTR) & None & CERCLA \\
\hline & 121 & Waste Oil Sumps, Bldg. 360 (TTR) & None & CERCLA \\
\hline & 122 & Area 3 Septic Systems (TTR) & None & CERCLA \\
\hline & 123 & Photographic Shop French Drains (TTR) & None & CERCLA \\
\hline & 124 & High Explosive Disposal Area (TTR) & None & CERCLA \\
\hline & 125 & Area 9 Landfill (TTR) & None & CERCLA \\
\hline & 126 & Mobile Photographic Laboratory (TTR) & None & CERCLA \\
\hline & 127 & $\begin{array}{l}\text { Non-Violent Explosive Destruct System } \\
\text { (NEDS) (TTR) }\end{array}$ & None & CERCLA \\
\hline & 128 & Antelope Lake (TTR) & None & CERCLA \\
\hline & 129 & Cactus Springs (TTR) & None & CERCLA \\
\hline
\end{tabular}


Table B-1. Environmental Restoration Project Sites by Activity Data Sheet (ADS) Number (Continued)

\begin{tabular}{|c|c|c|c|c|}
\hline $\begin{array}{l}\text { ADS No.- } \\
\text { Operable Unit }\end{array}$ & $\begin{array}{l}\text { Site } \\
\text { No. }\end{array}$ & Site Name & $\begin{array}{l}\text { RCRA/RFA } \\
\text { No. }\end{array}$ & Regulatory Driver \\
\hline \multirow{18}{*}{$\begin{array}{l}\text { DOE/NVO Resp.- } \\
\text { Responsibility of } \\
\text { Others (continued) }\end{array}$} & 130 & $\begin{array}{l}\text { Roller Coaster Radioactive } \\
\text { Decontamination Area }\end{array}$ & None & CERCLA \\
\hline & 131 & $\begin{array}{l}\text { Roller Coaster Sanitary Sewage } \\
\text { System and Lagoons (TTR) }\end{array}$ & None & CERCLA \\
\hline & 134 & Heavy Duty Shop Drains & None & CERCLA \\
\hline & 197 & Bomblet Pit (TTR) & None & CERCLA \\
\hline & 198 & Dump at Tonopah (TTR) & None & CERCLA \\
\hline & 253 & First Gas Station USTs & None & CERCLA \\
\hline & 254 & Second Gas Station USTs & None & CERCLA \\
\hline & 255 & Septic Tank 33-2 & None & CERCLA \\
\hline & 256 & Septic Tank 33-3 & None & CERCLA \\
\hline & 257 & Septic Tank 33-4 & None & CERCLA \\
\hline & 258 & Septic Tank 33-5 & None & CERCLA \\
\hline & 259 & Septic Tank 33-6 & None & CERCLA \\
\hline & 260 & Septic Tank 33-7 & None & CERCLA \\
\hline & 261 & Septic Tank 33-8 & None & CERCLA \\
\hline & 262 & Septic Tank 33-9 & None & CERCLA \\
\hline & 263 & Septic Tank 33-10 & None & CERCLA \\
\hline & 264 & Septic Tank 33-11 & None & CERCLA \\
\hline & 265 & Septic Tank 33-12 & None & CERCLA \\
\hline
\end{tabular}


Table B-1. Environmental Restoration Project Sites by Activity Data Sheet (ADS) Number (Continued)

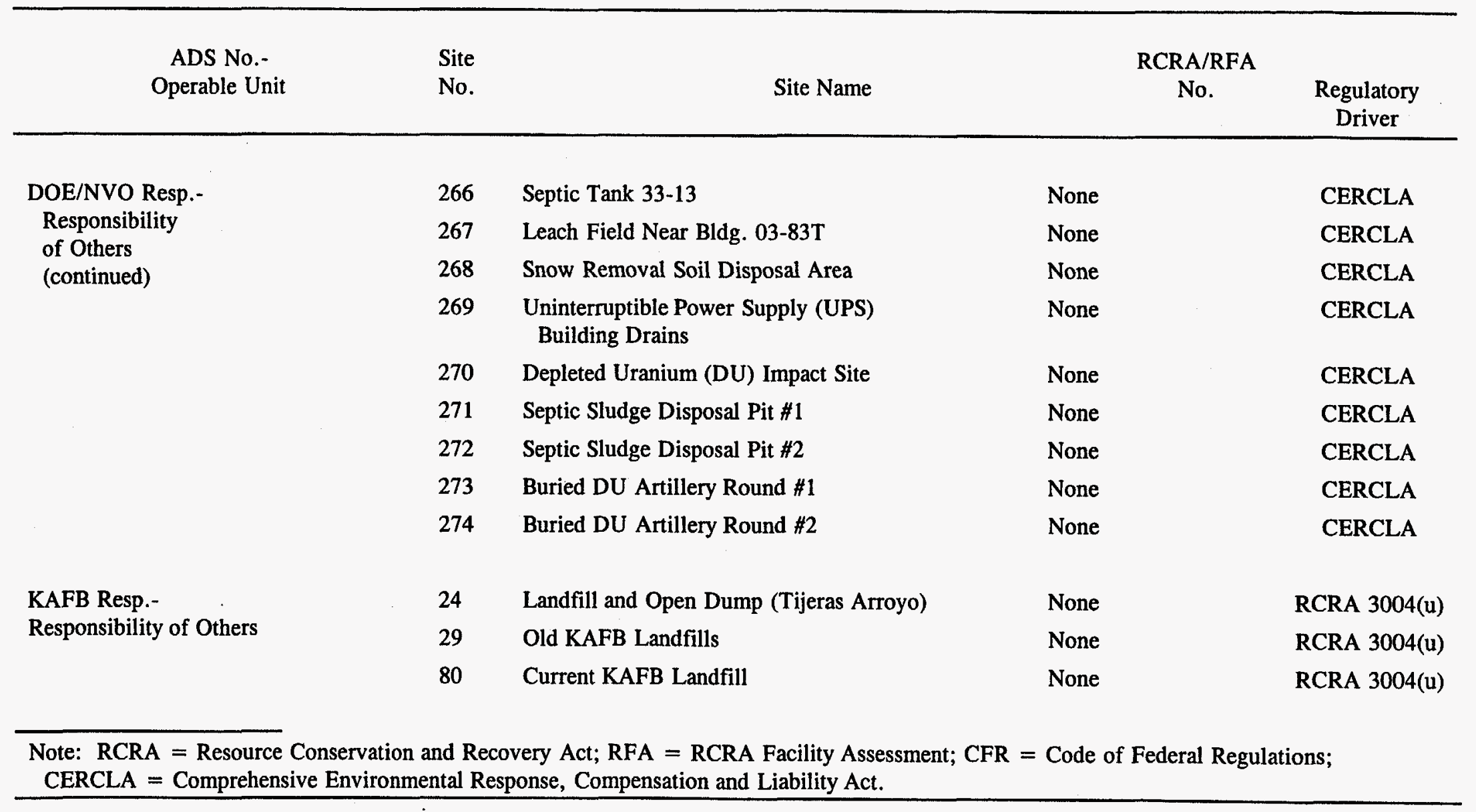


Table B-1. Environmental Restoration Project Sites by Activity Data Sheet (ADS) Number (Continued)

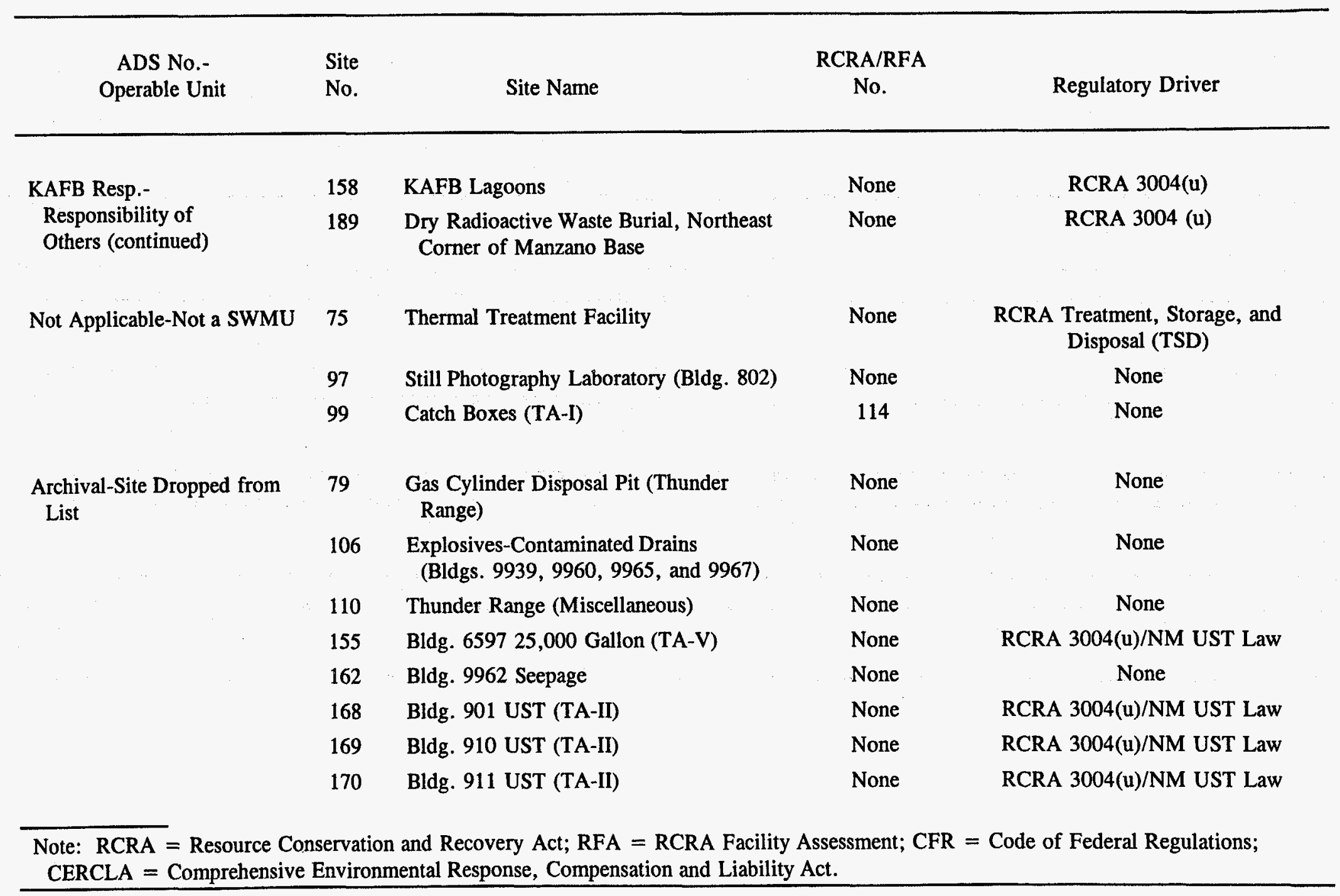


Table B-1. Environmental Restoration Project Sites by Activity Data Sheet (ADS) Number (Continued)

\begin{tabular}{|c|c|c|c|c|}
\hline $\begin{array}{l}\text { ADS No.- } \\
\text { Operable Unit }\end{array}$ & $\begin{array}{l}\text { Site } \\
\text { No. }\end{array}$ & Site Name & $\begin{array}{l}\text { RCRA/RFA } \\
\text { No. }\end{array}$ & Regulatory Driver \\
\hline \multirow{16}{*}{$\begin{array}{l}\text { Archival-Site Dropped } \\
\text { from List } \\
\text { (continued) }\end{array}$} & 171 & Bldg. 912 UST (TA-II) & None & RCRA 3004(u)/NM UST Law \\
\hline & 172 & Bldg. 888 UST (TA-I) & None & RCRA 3004(u)/NM UST Law \\
\hline & 173 & Bldg. 6525 UST (TA-III) & None & RCRA 3004(u)/NM UST Law \\
\hline & 174 & Bldg. 6581 UST (TA-IV) & None & RCRA 3004(u)/NM UST Law \\
\hline & 175 & Bldg. 6588 UST (TA-IV) & None & RCRA 3004(u)/NM UST Law \\
\hline & 176 & Bldg. 605 UST (TA-I) & None & RCRA 3004(u)/NM UST Law \\
\hline & 178 & Bldg. 6587 UST (TA-III) & None & RCRA 3004(u)/NM UST Law \\
\hline & 179 & Bldg. 7570 UST & None & RCRA 3004(u)/NM UST Law \\
\hline & 180 & Bldg. 6503 UST (TA-III) & None & RCRA 3004(u)/NM UST Law \\
\hline & 181 & Bldg. 6500 UST (TA-V) & None & RCRA 3004(u)/NM UST Law \\
\hline & 185 & Bldg. 863 (TA-I) & None & None \\
\hline & 195 & Experimental Test Pit & None & None \\
\hline & 212 & Bldg. 876 UST (TA-I) & None & RCRA 3004(u)/NM UST Law \\
\hline & 213 & Bldg. 880 UST (TA-I) & None & RCRA 3004(u)/NM UST Law \\
\hline & 214 & Bldg. 6505 UST (TA-III) & None & RCRA 3004(u)/NM UST Law \\
\hline & 215 & Bldg. 6536 UST (TA-III) & None & RCRA 3004(u)/NM UST Law \\
\hline
\end{tabular}

Note: RCRA = Resource Conservation and Recovery Act; RFA = RCRA Facility Assessment; CFR = Code of Federal Regulations CERCLA = Comprehensive Environmental Response, Compensation and Liability Act. 
Table B-1. Environmental Restoration Project Sites by Activity Data Sheet (ADS) Number (Concluded)

\begin{tabular}{|c|c|c|c|c|}
\hline $\begin{array}{l}\text { ADS No.- } \\
\text { Operable Unit }\end{array}$ & $\begin{array}{l}\text { Site } \\
\text { No. }\end{array}$ & Site Name & $\begin{array}{l}\text { RCRA/RFA } \\
\text { No. }\end{array}$ & Regulatory Driver \\
\hline \multirow{9}{*}{$\begin{array}{l}\text { Archival-Site Dropped } \\
\text { from List } \\
\text { (continued) }\end{array}$} & 216 & Bldg. 6596 UST (TA-V) & None & RCRA 3004(u)/NM UST Law \\
\hline & 217 & Bldg. 6630 UST (TA-III) & None & RCRA 3004(u)/NM UST Law \\
\hline & 218 & Bldg. 6720 UST (TA-III) & None & RCRA 3004(u)/NM UST Law \\
\hline & 219 & Tank 7 Burn Site (Lurance Canyon) & None & RCRA 3004(u)/NM UST Law \\
\hline & 220 & Bldg. 9832 UST (Coyote Test Field) & None & RCRA 3004(u)/NM UST Law \\
\hline & 221 & Bldg. 9970 UST (Coyote Test Field) & None & RCRA 3004(u)/NM UST Law \\
\hline & 222 & $\begin{array}{l}\text { Igloo Area Bldg. } 6018 \text { UST (Tijeras } \\
\text { Arroyo) }\end{array}$ & None & RCRA 3004(u)/NM UST Law \\
\hline & 223 & $\begin{array}{l}\text { Igloo Area Bldg. } 6028 \text { UST (Tijeras } \\
\text { Arroyo) }\end{array}$ & None & RCRA 3004(u)/NM UST Law \\
\hline & 224 & Bldg. 666A and 666B UST (Kauai) & None & None \\
\hline
\end{tabular}




\section{APPENDIX C}

NATIONAL ENVIRONMENTAL POLICY ACT DOCUMENTATION 
C-2 


\section{CONTENTS}

TABLES

Page

C-1 1994 SNL/NM Environmental Assessments Status . . . . . . . . . C-5

C-2 National Environmental Policy Act Documentation (Environmental

Checklists/Action Description Memoranda) and Approval Status . . . . . C C 7

REFERENCES $\ldots \ldots \ldots \ldots \ldots \ldots \ldots \ldots \ldots \ldots \ldots$ C-20 
Table C-1. 1994 SNL/NM Environmental Assessments (EAs) Status

\begin{tabular}{|c|c|c|c|}
\hline Title & $\begin{array}{l}\text { DOE Request } \\
\text { for EA }\end{array}$ & $\begin{array}{l}\text { Latest } \\
\text { EA Sent } \\
\text { to DOE }\end{array}$ & FONSI \\
\hline $\begin{array}{l}\text { Lurance Canyon Burn } \\
\text { Site }\end{array}$ & $08 / 11 / 89$ & & \\
\hline $\begin{array}{l}\text { Construction and Occupancy } \\
\text { of Robotic Manufacturing } \\
\text { Science Facility }\end{array}$ & $05 / 03 / 91$ & $12 / 10 / 93$ & $04 / 13 / 94$ \\
\hline $\begin{array}{l}\text { Construction and Occupancy } \\
\text { of Radioactive and Mixed } \\
\text { Waste Assay Facility }\end{array}$ & $03 / 25 / 91$ & & \\
\hline Coyote Canyon Test Complex & $11 / 10 / 92$ & & \\
\hline $\begin{array}{l}\text { Sol se Mete Aerial Cable } \\
\text { Facility }\end{array}$ & $03 / 11 / 92$ & $10 / 18 / 93$ & \\
\hline $\begin{array}{l}\text { Site-Wide Environmental } \\
\text { Assessments for the } \\
\text { Environmental Restoration } \\
\text { Project }\end{array}$ & $12 / 03 / 93$ & $02 / 14 / 94$ & \\
\hline $\begin{array}{l}\text { Atmospheric Radiation Test } \\
\text { Program }\end{array}$ & $02 / 23 / 92$ & & \\
\hline $\begin{array}{l}\text { Construction and Occupancy } \\
\text { of Processing and } \\
\text { Environmental Technology } \\
\text { Laboratory }\end{array}$ & $03 / 25 / 91$ & $11 / 16 / 94$ & \\
\hline $\begin{array}{l}\text { Technical Support Center } \\
\text { (GIF) }\end{array}$ & $12 / 19 / 90$ & $12 / 06 / 94$ & \\
\hline
\end{tabular}


Table C-1. 1994 SNL/NM Environmental Assessments (EAs) Status (Concluded)

\begin{tabular}{|c|c|c|c|}
\hline Title & $\begin{array}{l}\text { DOE Request } \\
\text { for EA }\end{array}$ & $\begin{array}{l}\text { EA Sent } \\
\text { to DOE }\end{array}$ & FONSI \\
\hline $\begin{array}{l}\text { Neutron Measurement } \\
\text { Laboratory }\end{array}$ & $12 / 10 / 90$ & & \\
\hline $\begin{array}{l}\text { Relocation of Neutron } \\
\text { Generator and Switch Tube } \\
\text { Prototyping }\end{array}$ & $11 / 10 / 92$ & $01 / 26 / 94$ & $04 / 08 / 94$ \\
\hline $\begin{array}{l}\text { Shipment of Low-Level Waste } \\
\text { to the Nevada Test Site }\end{array}$ & $10 / 15 / 93$ & $09 / 14 / 94$ & \\
\hline Jupiter Accelerator Facility & & $06 / 00 / 94$ & \\
\hline $\begin{array}{l}\text { General Purpose Heat Source } \\
\text { Radioisotope Thermoelectric } \\
\text { Generator Safety Verification } \\
\text { Testing 10,000-ft Sled Track } \\
\text { Facility }\end{array}$ & $08 / 31 / 94$ & $01 / 16 / 95$ & $02 / 13 / 95$ \\
\hline $\begin{array}{l}\text { Radiopharmaceutical Program, } \\
\text { Medical Isotope Production } \\
\text { Program (Molybdenum 99) }\end{array}$ & $11 / 15 / 94$ & $02 / 06 / 95$ & \\
\hline
\end{tabular}


Table C-2. National Environmental Policy Act Documentation (Environmental Checklists/Action Description Memoranda) and Approval Status

\begin{tabular}{|c|c|c|c|}
\hline Title & $\begin{array}{l}\text { Memo to } \\
\text { DOE }\end{array}$ & $\begin{array}{c}\text { DOE } \\
\text { Approval }\end{array}$ & $\begin{array}{l}\text { DOE Request for } \\
\text { Environmental } \\
\text { Assessment }\end{array}$ \\
\hline Gateway District & $11 / 01 / 93$ & $02 / 14 / 94$ & \\
\hline $\begin{array}{l}\text { Low Toxicity Obscurant } \\
\text { Smoke Testing }\end{array}$ & $10 / 20 / 93$ & $01 / 04 / 94$ & \\
\hline Expansion of Tandem Target Room & $10 / 20 / 93$ & $01 / 04 / 94$ & \\
\hline $\begin{array}{l}\text { Decontamination and Disposal of } \\
\text { Buildings } 824,829,838 \text {, and } 839\end{array}$ & $10 / 20 / 93$ & $02 / 14 / 94$ & \\
\hline $\begin{array}{l}\text { AT } 400 \text { Fire Tests } 02 / 94 \text { through } \\
03 / 94\end{array}$ & $11 / 02 / 93$ & $01 / 04 / 94$ & \\
\hline $\begin{array}{l}\text { Radiant Heat Tests } \\
\text { Calendar Year } 1994\end{array}$ & $11 / 04 / 93$ & $01 / 12 / 94$ & \\
\hline $\begin{array}{l}\text { Directed Infrared Countermeasures } \\
\text { at Cable Site }\end{array}$ & $11 / 29 / 93$ & & \\
\hline $\begin{array}{l}\text { General Accident Prevention } \\
\text { (GAP) Container Tests }\end{array}$ & $12 / 10 / 93$ & $02 / 14 / 94$ & \\
\hline Sticky Foam Characterization Tests & $12 / 20 / 93$ & $03 / 15 / 94$ & \\
\hline $\begin{array}{l}\text { Fifth-Scale } 747 \text { Aircraft Crash } \\
\text { Test at Rocket Sled }\end{array}$ & $12 / 10 / 93$ & $03 / 15 / 94$ & \\
\hline $\begin{array}{l}\text { Laboratory Operations in the } \\
\text { Materials and Process } \\
\text { Science Organization }\end{array}$ & $02 / 15 / 94$ & $03 / 15 / 94$ & \\
\hline $\begin{array}{l}\text { Lease Space in the Advance } \\
\text { Materials Building (UNM) }\end{array}$ & $08 / 26 / 93$ & $03 / 15 / 94$ & \\
\hline $\begin{array}{l}\text { Massively Parallel Computer } \\
\text { Research Laboratory (MPCRL) } \\
\text { Annex (Technical Area IV } \\
\text { near Building 980) }\end{array}$ & $12 / 15 / 93$ & $03 / 15 / 94$ & \\
\hline
\end{tabular}


Table C-2. National Environmental Policy Act Documentation (Environmental Checklists/Action Description Memoranda) and Approval Status (Continued)

\begin{tabular}{|c|c|c|c|}
\hline Title & $\begin{array}{l}\text { Memo to } \\
\text { DOE }\end{array}$ & $\begin{array}{c}\text { DOE } \\
\text { Approval }\end{array}$ & $\begin{array}{l}\text { DOE Request for } \\
\text { Environmental } \\
\text { Assessment }\end{array}$ \\
\hline Agility Primed & $02 / 22 / 94$ & $04 / 01 / 94$ & \\
\hline $\begin{array}{l}\text { Sensor Fuzed Weapon (SFW) } \\
\text { Testing at Aerial Cable Site }\end{array}$ & $01 / 27 / 94$ & $08 / 12 / 94$ & \\
\hline $\begin{array}{l}\text { Voluntary Corrective Action, Gas } \\
\text { Cylinder Disposal Site }\end{array}$ & $02 / 02 / 94$ & $06 / 24 / 94$ & \\
\hline $\begin{array}{l}\text { Manzano Saddle Radio Site } \\
\text { Construction }\end{array}$ & $02 / 02 / 94$ & $04 / 01 / 94$ & \\
\hline DOE Administrative Office Building & $02 / 10 / 94$ & $03 / 24 / 94$ & \\
\hline Installation of Fuel Oil Tanks & $02 / 14 / 94$ & $04 / 21 / 94$ & \\
\hline $\begin{array}{l}\text { Hobart Advanced Welding Control } \\
\text { System (HAWCS) Robotics Arc } \\
\text { Welding Laboratory }\end{array}$ & $02 / 18 / 94$ & $05 / 03 / 94$ & \\
\hline Building 835 Shipping and Receiving & $02 / 22 / 94$ & $05 / 13 / 94$ & \\
\hline Landfill Integrated Demonstration & $02 / 23 / 94$ & $04 / 15 / 94$ & \\
\hline $\begin{array}{l}\text { Radiography System in Support of } \\
\text { Radioactive/Mixed Waste } \\
\text { Characterization }\end{array}$ & $04 / 21 / 94$ & 06/03/94 & \\
\hline GAP Fire Test II & $02 / 28 / 94$ & 07/02/94 & \\
\hline SGT Panel Fire Tests & $02 / 28 / 94$ & $07 / 02 / 94$ & \\
\hline $\begin{array}{l}\text { Interim Storage of Radioactive } \\
\text { Waste at Building } 6920 \text { Site }\end{array}$ & $03 / 14 / 94$ & $05 / 16 / 94$ & \\
\hline Vehicle Control Research & $02 / 28 / 94$ & $05 / 16 / 94$ & \\
\hline
\end{tabular}


Table C-2. National Environmental Policy Act Documentation (Environmental Checklists/Action Description Memoranda) and Approval Status (Continued)

\begin{tabular}{|c|c|c|c|}
\hline Title & $\begin{array}{l}\text { Memo to } \\
\text { DOE }\end{array}$ & $\begin{array}{c}\text { DOE } \\
\text { Approval }\end{array}$ & $\begin{array}{l}\text { DOE Request for } \\
\text { Environmental } \\
\text { Assessment }\end{array}$ \\
\hline $\begin{array}{l}\text { Disposal of Radioactive and Mixed } \\
\text { Waste at Envirocare }\end{array}$ & $03 / 02 / 94$ & $03 / 17 / 94$ & \\
\hline Reentry Body Impact Fuze Flights & $03 / 02 / 94$ & $05 / 27 / 94$ & \\
\hline $\begin{array}{l}\text { Asbestos Management Fiscal Year } \\
1994 \text { (FY94) through FY98 }\end{array}$ & 03/04/94 & $05 / 16 / 94$ & \\
\hline $\begin{array}{l}\text { Acceptance of CT } 1600 \text { Cables at } \\
\text { SNL/NM }\end{array}$ & $04 / 21 / 94$ & $05 / 11 / 94$ & \\
\hline $\begin{array}{l}\text { Voluntary Corrective Action, } \\
\text { ER Project, Former Underground } \\
\text { Storage Tank (UST) 9970-1 }\end{array}$ & $03 / 07 / 94$ & & \\
\hline $\begin{array}{l}\text { Shock Thermodynamics Applied } \\
\text { Research (STAR) Facility }\end{array}$ & 03/09/94 & $06 / 03 / 94$ & \\
\hline $\begin{array}{l}\text { Less-Than-Lethal Program, } \\
\text { Aqueous Foam }\end{array}$ & $03 / 21 / 94$ & $05 / 16 / 94$ & \\
\hline Steam Reforming Pilot Study & $05 / 02 / 94$ & $06 / 03 / 94$ & \\
\hline $\begin{array}{l}\text { Mine Detection Using Backscattered } \\
\text { X-Rays }\end{array}$ & $03 / 15 / 94$ & $05 / 16 / 94$ & \\
\hline $\begin{array}{l}\text { Theater Defense Countermeasures } \\
\text { Program }\end{array}$ & $03 / 16 / 94$ & 03/03/94 & \\
\hline $\begin{array}{l}\text { Radiopharmaceuticals Program } \\
\text { (Molybdenum 99) }\end{array}$ & $11 / 07 / 94$ & & $11 / 15 / 94$ \\
\hline Damocles Project & $03 / 22 / 94$ & $05 / 13 / 94$ & \\
\hline $\begin{array}{l}\text { Building } 605 \text { Environment, } \\
\text { Safety, and Health } \\
\text { (ES\&H) Additions }\end{array}$ & $03 / 22 / 94$ & $05 / 13 / 94$ & \\
\hline $\begin{array}{l}\text { Routine Operating and Maintenance } \\
\text { Activities FY95 through FY98 }\end{array}$ & $04 / 27 / 94$ & $09 / 16 / 94$ & \\
\hline
\end{tabular}


Table C-2. National Environmental Policy Act Documentation (Environmental Checklists/Action Description Memoranda) and Approval Status (Continued)

\begin{tabular}{|c|c|c|c|}
\hline Title & $\begin{array}{l}\text { Memo to } \\
\text { DOE }\end{array}$ & $\begin{array}{c}\text { DOE } \\
\text { Approval }\end{array}$ & $\begin{array}{l}\text { DOE Request for } \\
\text { Environmental } \\
\text { Assessment }\end{array}$ \\
\hline $\begin{array}{l}\text { Modification of Measurements } \\
\text { Laboratory, Building } 869, \\
\text { Room } 831\end{array}$ & $03 / 29 / 94$ & $05 / 13 / 94$ & \\
\hline $\begin{array}{l}\text { 3-D Ultrasound Imaging for Diagnosis } \\
\text { of Battlefield Wounds }\end{array}$ & $03 / 25 / 94$ & $05 / 16 / 94$ & \\
\hline $\begin{array}{l}\text { Off-Route Smart Mine Clearance } \\
\text { (OSRMC) }\end{array}$ & $04 / 08 / 94$ & $05 / 16 / 94$ & \\
\hline Low-Cost Guidance Technology & $05 / 20 / 94$ & $06 / 24 / 94$ & \\
\hline $\begin{array}{l}\text { Thermal Hazards of Energetic } \\
\text { Materials }\end{array}$ & $05 / 20 / 94$ & $07 / 02 / 94$ & \\
\hline Safing Arming and Firing Technology & $05 / 26 / 94$ & & \\
\hline Scannerless Range Imaging & $03 / 08 / 94$ & $07 / 02 / 94$ & \\
\hline $\begin{array}{l}\text { Demilitarization and Disposal } \\
\text { Technologies }\end{array}$ & $04 / 28 / 94$ & $09 / 16 / 94$ & \\
\hline $\begin{array}{l}\text { Personnel Status Monitor System } \\
\text { for Battlefield Use }\end{array}$ & 03/30/94 & $05 / 16 / 94$ & \\
\hline Liquid Waste Treatability Studies & $03 / 29 / 94$ & $07 / 22 / 94$ & \\
\hline $\begin{array}{l}\text { Advance Pulsed Power Research } \\
\text { Module }\end{array}$ & $04 / 01 / 94$ & $06 / 03 / 94$ & \\
\hline Energetic Materials Development & $04 / 05 / 94$ & $05 / 03 / 94$ & \\
\hline $\begin{array}{l}\text { General Accident Protection } \\
\text { Container Testing }\end{array}$ & $04 / 12 / 94$ & $06 / 03 / 94$ & \\
\hline
\end{tabular}


Table C-2. National Environmental Policy Act Documentation (Environmental Checklists/Action Description Memoranda) and Approval Status (Continued)

\begin{tabular}{|c|c|c|c|}
\hline Title & $\begin{array}{l}\text { Memo to } \\
\text { DOE }\end{array}$ & $\begin{array}{c}\text { DOE } \\
\text { Approval }\end{array}$ & $\begin{array}{l}\text { DOE Request for } \\
\text { Environmental } \\
\text { Assessment }\end{array}$ \\
\hline LC Oscillator & $04 / 14 / 94$ & $05 / 10 / 94$ & \\
\hline $\begin{array}{l}\text { Precision Munition Assessment } \\
\text { Program }\end{array}$ & $04 / 15 / 94$ & $05 / 27 / 94$ & \\
\hline $\begin{array}{l}\text { Impact Testing of Quarter Scale } \\
\text { Safe Secure Trailers (SST) } \\
\text { at Sled Track }\end{array}$ & $04 / 15 / 94$ & $05 / 27 / 94$ & \\
\hline $\begin{array}{l}\text { Maintenance Materials } \\
\text { Characterization }\end{array}$ & $04 / 20 / 94$ & $05 / 06 / 94$ & \\
\hline $\begin{array}{l}\text { Solar Detoxification as a Means of } \\
\text { Eliminating Secondary Waste }\end{array}$ & $04 / 26 / 94$ & $06 / 27 / 94$ & \\
\hline $\begin{array}{l}\text { Automated Path Planning for Robotic } \\
\text { Application of Paint Coating }\end{array}$ & $05 / 13 / 94$ & $06 / 24 / 94$ & \\
\hline DNA Verification Support & $05 / 16 / 94$ & $06 / 24 / 94$ & \\
\hline $\begin{array}{l}\text { Impact Test of B61 at Rocket } \\
\text { Launcher }\end{array}$ & $05 / 12 / 94$ & $07 / 01 / 94$ & \\
\hline Extension of Existing Parking Lot & $05 / 17 / 94$ & $06 / 20 / 94$ & \\
\hline $\begin{array}{l}\text { Treatability Studies for Inerting } \\
\text { Energetic Materials in Mixed Waste }\end{array}$ & $05 / 20 / 94$ & $06 / 24 / 94$ & \\
\hline $\begin{array}{l}\text { Construction and Operation of Wet } \\
\text { Chemistry Laboratories }\end{array}$ & $06 / 21 / 94$ & $08 / 18 / 94$ & \\
\hline $\begin{array}{l}\text { Enhanced Utility Fraud Risk } \\
\text { Estimation Project }\end{array}$ & $05 / 18 / 94$ & $06 / 24 / 94$ & \\
\hline Optical Diagnostics Laboratory & $05 / 19 / 94$ & $07 / 02 / 94$ & \\
\hline
\end{tabular}


Table C-2. National Environmental Policy Act Documentation (Environmental Checklists/Action Description Memoranda) and Approval Status (Continued)

\begin{tabular}{|c|c|c|c|}
\hline Title & $\begin{array}{l}\text { Memo to } \\
\text { DOE }\end{array}$ & $\begin{array}{c}\text { DOE } \\
\text { Approval }\end{array}$ & $\begin{array}{l}\text { DOE Request for } \\
\text { Environmental } \\
\text { Assessment }\end{array}$ \\
\hline $\begin{array}{l}\text { Photoconductive Semiconductor } \\
\text { Switches (PCSS) for Fuzing }\end{array}$ & $05 / 20 / 94$ & $06 / 24 / 94$ & \\
\hline $\begin{array}{l}\text { Long-Life Thermal Battery for } \\
\text { Sonobuoy Applications }\end{array}$ & $05 / 27 / 94$ & $06 / 09 / 94$ & \\
\hline $\begin{array}{l}\text { Absolute Time Firing Device for } \\
\text { Mines }\end{array}$ & $05 / 26 / 94$ & & \\
\hline Annealing Demonstration Project & $06 / 06 / 94$ & $08 / 26 / 94$ & \\
\hline HU-25 Aircraft Non-Destructive & $06 / 03 / 94$ & $07 / 22 / 94$ & \\
\hline $\begin{array}{l}\text { Component Irradiation Projects, } \\
\text { Technical Area V }\end{array}$ & 06/03/94 & $09 / 13 / 94$ & \\
\hline $\begin{array}{l}\text { Cable Target Demonstration for } \\
\text { Redstone }\end{array}$ & 06/03/94 & $07 / 20 / 94$ & \\
\hline Reactive Metals Treatability Study & $06 / 03 / 94$ & $07 / 22 / 94$ & \\
\hline $\begin{array}{c}\text { Voluntary Corrective Action (VCA) } \\
\text { Activity Data Sheet (ADS) } 1309\end{array}$ & 06/06/94 & 07/29/94 & \\
\hline Recycling Transfer Station & $06 / 07 / 94$ & $07 / 22 / 94$ & \\
\hline $\begin{array}{l}\text { Relocation of Non-Nuclear } \\
\text { Consolidation Shelf Life Storage }\end{array}$ & $07 / 14 / 94$ & $07 / 26 / 94$ & \\
\hline Electrokinetic Extraction & $07 / 20 / 94$ & $08 / 05 / 94$ & \\
\hline $\begin{array}{l}\text { Automated Bagout Canout Program } \\
\text { for Los Alamos National } \\
\text { Laboratory }\end{array}$ & $06 / 09 / 94$ & $07 / 22 / 94$ & \\
\hline
\end{tabular}


Table C-2. National Environmental Policy Act Documentation (Environmental Checklists/Action Description Memoranda) and Approval Status (Continued)

\begin{tabular}{|c|c|c|c|}
\hline Title & $\begin{array}{l}\text { Memo to } \\
\text { DOE }\end{array}$ & $\begin{array}{c}\text { DOE } \\
\text { Approval }\end{array}$ & $\begin{array}{l}\text { DOE Request for } \\
\text { Environmental } \\
\text { Assessment }\end{array}$ \\
\hline Stellar X-Ray Polarimeter (SXRP) & $06 / 09 / 94$ & $07 / 22 / 94$ & \\
\hline $\begin{array}{l}\text { U.S. Air Force/Strategic Space } \\
\text { Division (USAF/SSD) Global } \\
\text { Positioning System }\end{array}$ & $06 / 09 / 94$ & $07 / 29 / 94$ & \\
\hline $\begin{array}{l}\text { Laboratory Operations Chemical } \\
\text { and Physical Science }\end{array}$ & $06 / 10 / 94$ & $09 / 16 / 94$ & \\
\hline Relocate Glovebox to $807 / 3089$ & $06 / 12 / 94$ & $06 / 24 / 94$ & \\
\hline $\begin{array}{l}\text { Sawdust Fuel in Small Wind-Shielded } \\
\text { Facility (SWISH) }\end{array}$ & $06 / 23 / 94$ & $07 / 29 / 94$ & \\
\hline $\begin{array}{l}\text { Decontamination and Demolition } \\
\text { (D\&D) of Buildings 866, 950, } \\
\text { 951, and Camera Dome A }\end{array}$ & $06 / 21 / 94$ & $07 / 22 / 94$ & \\
\hline $\begin{array}{l}\text { Aircraft Safety Validation System } \\
\text { Development }\end{array}$ & $06 / 24 / 94$ & $07 / 29 / 94$ & \\
\hline B83-OJTA1 Modified Drop Tests & $06 / 24 / 94$ & $06 / 30 / 94$ & \\
\hline $\begin{array}{l}\text { Synthetic Aperture Radar Open } \\
\text { Skies (SAROS) }\end{array}$ & $08 / 03 / 94$ & $08 / 19 / 94$ & \\
\hline Strip Phase II & $07 / 07 / 94$ & $07 / 22 / 94$ & \\
\hline $\begin{array}{l}\text { Seafloor Earthquake Measurement } \\
\text { System }\end{array}$ & $06 / 28 / 94$ & $07 / 22 / 94$ & \\
\hline $\begin{array}{l}\text { Removal of Surface Radioactive } \\
\text { Contamination VCA } \\
\text { Technical Area III }\end{array}$ & $06 / 28 / 94$ & & \\
\hline
\end{tabular}


Table C-2. National Environmental Policy Act Documentation (Environmental Checklists/Action Description Memoranda) and Approval Status (Continued)

\begin{tabular}{|c|c|c|c|}
\hline Title & $\begin{array}{l}\text { Memo to } \\
\text { DOE }\end{array}$ & $\begin{array}{c}\text { DOE } \\
\text { Approval }\end{array}$ & $\begin{array}{l}\text { DOE Request for } \\
\text { Environmental } \\
\text { Assessment }\end{array}$ \\
\hline $\begin{array}{l}\text { Measurement and Signature } \\
\text { Intelligence (MASINT) Unattended } \\
\text { Ground Sensors }\end{array}$ & $06 / 29 / 94$ & $06 / 30 / 94$ & \\
\hline $\begin{array}{l}\text { Air Force Technical Applications } \\
\text { Center (AFTAC) Demonstration } \\
\text { Seismic Verification System } \\
\text { (DSVS) Next Steps }\end{array}$ & $07 / 07 / 94$ & $07 / 29 / 94$ & \\
\hline Engineering Services & $07 / 07 / 94$ & $07 / 28 / 94$ & \\
\hline Cellular Tower Installation & $07 / 06 / 94$ & $07 / 22 / 94$ & \\
\hline $\begin{array}{l}\text { Demonstration of Universal } \\
\text { Electric Transportation Subsystems }\end{array}$ & $07 / 06 / 94$ & $07 / 22 / 94$ & \\
\hline $\begin{array}{l}\text { Division } 2000 \text { Electric/Mechanical } \\
\text { Laboratories FY94 and FY95 }\end{array}$ & $07 / 08 / 94$ & $11 / 25 / 94$ & \\
\hline $\begin{array}{l}\text { Materials Processes in Division } 2000 \\
\text { FY94 and FY95 }\end{array}$ & $07 / 08 / 94$ & $11 / 25 / 94$ & \\
\hline $\begin{array}{l}\text { Laboratory Chemical Operations in } \\
\text { Division } 2000 \text { FY94 and FY95 }\end{array}$ & $07 / 08 / 94$ & $11 / 25 / 94$ & \\
\hline $\begin{array}{l}\text { Federal Aviation Administration } \\
\text { (FAA) Explosive Detection } \\
\text { Systems }\end{array}$ & $07 / 21 / 94$ & $08 / 05 / 94$ & \\
\hline $\begin{array}{l}\text { X-ray Multi-Mirror Mission (XMM) } \\
\text { Monitor Digital Processing Unit } \\
\text { (DPU) Design and Fabrication }\end{array}$ & $07 / 26 / 94$ & $08 / 05 / 94$ & \\
\hline $\begin{array}{l}\text { Project Activities in the Systems } \\
\text { Research Center for FY } 94 \\
\text { and FY95 }\end{array}$ & $07 / 15 / 94$ & $08 / 26 / 94$ & \\
\hline
\end{tabular}


Table C-2. National Environmental Policy Act Documentation (Environmental Checklists/Action Description Memoranda) and Approval Status (Continued)

\begin{tabular}{|c|c|c|c|}
\hline Title & $\begin{array}{l}\text { Memo to } \\
\text { DOE }\end{array}$ & $\begin{array}{c}\text { DOE } \\
\text { Approval }\end{array}$ & $\begin{array}{l}\text { DOE Request for } \\
\text { Environmental } \\
\text { Assessment }\end{array}$ \\
\hline $\begin{array}{l}\text { Demonstration and Operation of } \\
\text { Smoke Emission Reduction } \\
\text { Facility (SMERF) FY94 and FY95 }\end{array}$ & $07 / 18 / 94$ & $08 / 12 / 94$ & \\
\hline $\begin{array}{l}\text { Mechanics of Grandular Materials } \\
\text { (MGM) Compression Fixtures }\end{array}$ & $07 / 27 / 94$ & $08 / 05 / 94$ & \\
\hline Subsystem Test Facility & $07 / 11 / 94$ & $08 / 17 / 94$ & \\
\hline $\begin{array}{l}\text { Start Specific Radiation } \\
\text { Detection Equipment (RDE) }\end{array}$ & $08 / 03 / 94$ & $08 / 31 / 94$ & \\
\hline $\begin{array}{l}\text { Advance Lithography Tool for } \\
\text { Large Area Flat Panel Display }\end{array}$ & $08 / 11 / 94$ & $08 / 26 / 94$ & \\
\hline $\begin{array}{l}\text { Integrated Circuit Plastic } \\
\text { Reliability Studies }\end{array}$ & $07 / 26 / 94$ & $08 / 05 / 94$ & \\
\hline $\begin{array}{l}\text { Timer/Driver Fabrication in } \\
\text { Building } 9960\end{array}$ & $09 / 01 / 94$ & $09 / 16 / 94$ & \\
\hline $\begin{array}{l}\text { Design and Development of } \\
\text { Communications Control } \\
\text { Technology }\end{array}$ & $07 / 29 / 94$ & $08 / 03 / 94$ & \\
\hline $\begin{array}{l}\text { Naval Coastal Systems Center } \\
\text { (NCSC) Sensor Deployment } \\
\text { Parachute System }\end{array}$ & $08 / 01 / 94$ & $08 / 15 / 94$ & \\
\hline $\begin{array}{l}\text { Photovoltaics for Military } \\
\text { Application }\end{array}$ & $08 / 17 / 94$ & & \\
\hline $\begin{array}{l}\text { Tactical Equipment Concepts } \\
\text { Development }\end{array}$ & $08 / 03 / 94$ & $08 / 26 / 94$ & \\
\hline
\end{tabular}


Table C-2. National Environmental Policy Act Documentation (Environmental Checklists/Action Description Memoranda) and Approval Status (Continued)

\begin{tabular}{|c|c|c|c|}
\hline Title & $\begin{array}{l}\text { Memo to } \\
\text { DOE }\end{array}$ & $\begin{array}{c}\text { DOE } \\
\text { Approval }\end{array}$ & $\begin{array}{l}\text { DOE Request for } \\
\text { Environmental } \\
\text { Assessment }\end{array}$ \\
\hline $\begin{array}{l}\text { Headquarters Electronic Service } \\
\text { Command (HQ ESC)/AVJ Physical } \\
\text { Security Programs }\end{array}$ & $08 / 03 / 94$ & $08 / 19 / 94$ & \\
\hline $\begin{array}{l}\text { Impact Test of Simulated Heat } \\
\text { Source Safety Verification Testing }\end{array}$ & $08 / 15 / 94$ & & $08 / 23 / 84$ \\
\hline $\begin{array}{l}\text { Radiation Detection Capability } \\
\text { (Radec) Mass/Thermal Simulator } \\
\text { for Defense Satellite Program } \\
\text { (DSP) }\end{array}$ & $08 / 11 / 94$ & $08 / 26 / 94$ & \\
\hline $\begin{array}{l}\text { Miniaturing Satellite Threat } \\
\text { Reporting System }\end{array}$ & $08 / 11 / 94$ & $08 / 26 / 94$ & \\
\hline MASINT Sensor Support Program & $08 / 11 / 94$ & $09 / 12 / 94$ & \\
\hline $\begin{array}{l}\text { Department of Defense (DOD) } \\
\text { Aerial Cable Range } \\
\text { Development }\end{array}$ & $08 / 11 / 94$ & $09 / 16 / 94$ & \\
\hline $\begin{array}{l}\text { High-Powered Microwave Technology } \\
\text { Project }\end{array}$ & $08 / 15 / 94$ & $10 / 07 / 94$ & \\
\hline $\begin{array}{l}\text { Design and Fabrication of Electronic } \\
\text { Interface (BIRD NEST) }\end{array}$ & $08 / 15 / 94$ & $09 / 12 / 94$ & \\
\hline $\begin{array}{l}\text { Communication Systems Hardware } \\
\text { Evaluation and Study }\end{array}$ & $08 / 15 / 94$ & $09 / 12 / 94$ & \\
\hline $\begin{array}{l}\text { Design and Development of } \\
\text { Communication Control } \\
\text { Technology (Duplicate) }\end{array}$ & $08 / 15 / 94$ & 09/12/94 & \\
\hline
\end{tabular}


Table C-2. National Environmental Policy Act Documentation (Environmental Checklists/Action Description Memoranda) and Approval Status (Continued)

\begin{tabular}{|c|c|c|c|}
\hline Title & $\begin{array}{l}\text { Memo to } \\
\text { DOE }\end{array}$ & $\begin{array}{c}\text { DOE } \\
\text { Approval }\end{array}$ & $\begin{array}{l}\text { DOE Request for } \\
\text { Environmental } \\
\text { Assessment }\end{array}$ \\
\hline $\begin{array}{l}\text { Sensor Integration and Evaluation } \\
\text { Study Program }\end{array}$ & $08 / 15 / 94$ & $09 / 12 / 94$ & \\
\hline $\begin{array}{l}\text { System Vulnerability Analysis, } \\
\text { Project Museum }\end{array}$ & 08/19/94 & $09 / 12 / 94$ & \\
\hline $\begin{array}{l}\text { Surveillance and Reconnaissance } \\
\text { Ground Equipment (SARGE) }\end{array}$ & $08 / 19 / 94$ & $09 / 26 / 94$ & \\
\hline $\begin{array}{l}\text { Satellite W-Sensor Testing with } \\
\text { the Sniper Pulser }\end{array}$ & $08 / 25 / 94$ & $10 / 04 / 94$ & \\
\hline $\begin{array}{l}\text { National Aeronautics and Space } \\
\text { Administration (NASA) Rocket } \\
\text { Recovery System }\end{array}$ & $08 / 11 / 94$ & $08 / 26 / 94$ & \\
\hline $\begin{array}{l}\text { Design and Fabrication of a } \\
\text { Mechanical Control System }\end{array}$ & 09/01/94 & $09 / 20 / 94$ & \\
\hline Storage at Manzano Base Bunkers & $08 / 30 / 94$ & $10 / 17 / 94$ & \\
\hline Thin Film Vapor Deposition & $09 / 01 / 94$ & $10 / 07 / 94$ & \\
\hline Exploratory Drilling Vale & 09/15/94 & & \\
\hline Exploratory Drilling Newberry & $09 / 15 / 94$ & $12 / 02 / 94$ & \\
\hline $\begin{array}{l}\text { W76 Neutron Generator } \\
\text { Recertification }\end{array}$ & 09/06/94 & $10 / 04 / 94$ & \\
\hline $\begin{array}{l}\text { Advance Exterior Intrusion Detection } \\
\text { and Assessment System }\end{array}$ & $09 / 08 / 94$ & $09 / 16 / 94$ & \\
\hline $\begin{array}{l}\text { Joint Surveillance Target Attack } \\
\text { Radar System (STARS) Automatic } \\
\text { Target Recognition (ATR) ADT }\end{array}$ & $09 / 08 / 94$ & $09 / 16 / 94$ & \\
\hline
\end{tabular}


Table C-2. National Environmental Policy Act Documentation (Environmental Checklists/Action Description Memoranda) and Approval Status (Continued)

\begin{tabular}{|c|c|c|c|}
\hline Title & $\begin{array}{l}\text { Memo to } \\
\text { DOE }\end{array}$ & $\begin{array}{c}\text { DOE } \\
\text { Approval }\end{array}$ & $\begin{array}{l}\text { DOE Request for } \\
\text { Environmental } \\
\text { Assessment }\end{array}$ \\
\hline $\begin{array}{l}\text { United States Strategic } \\
\text { Command (USSTRACOM) } \\
\text { Commander in Chief } \\
\text { (CINC) Mobile Alternate } \\
\text { Headquarters }\end{array}$ & $09 / 08 / 94$ & & \\
\hline DNA Penetrator & $09 / 12 / 94$ & $10 / 25 / 94$ & \\
\hline $\begin{array}{l}\text { Intermediate Nuclear Forces/ } \\
\text { Strategic Arms Reduction } \\
\text { Treaty (INF/START) Radiation } \\
\text { Equipment }\end{array}$ & $09 / 15 / 94$ & $10 / 31 / 94$ & \\
\hline $\begin{array}{l}\text { State of the Art Photovoltaic } \\
\text { Arrays }\end{array}$ & $10 / 12 / 94$ & $12 / 09 / 94$ & \\
\hline $\begin{array}{l}\text { Protective Sample Container } \\
\text { Development }\end{array}$ & $10 / 03 / 94$ & $01 / 08 / 95$ & \\
\hline $\begin{array}{l}\text { Temporary Site for Robotic } \\
\text { Building and Digging Site }\end{array}$ & $12 / 20 / 94$ & $02 / 03 / 94$ & \\
\hline Glass Cutter for Sniper Support & $09 / 21 / 94$ & & \\
\hline Modifications to Building 6596 East & $09 / 27 / 94$ & $02 / 03 / 95$ & \\
\hline Subsurface Gas Flowmeter & $10 / 11 / 94$ & $01 / 12 / 95$ & \\
\hline $\begin{array}{l}\text { Movement of Projects/Personnel } \\
\text { to Independent Vulnerability } \\
\text { Assessment Facility (IVAF) }\end{array}$ & $10 / 11 / 94$ & $10 / 19 / 94$ & \\
\hline Mayak Site/Visit - Survey & $11 / 10 / 94$ & $12 / 12 / 94$ & \\
\hline
\end{tabular}


Table C-2. National Environmental Policy Act Documentation (Environmental Checklists/Action Description Memoranda) and Approval Status (Continued)

\begin{tabular}{|c|c|c|c|}
\hline Title & $\begin{array}{l}\text { Memo to } \\
\text { DOE }\end{array}$ & $\begin{array}{c}\text { DOE } \\
\text { Approval }\end{array}$ & $\begin{array}{l}\text { DOE Request for } \\
\text { Environmental } \\
\text { Assessment }\end{array}$ \\
\hline $\begin{array}{l}\text { Development of Focus Ion Beam } \\
\text { Capabilities }\end{array}$ & $10 / 17 / 94$ & & \\
\hline $\begin{array}{l}\text { Consortium Technology } \\
\text { Demonstration }\end{array}$ & $11 / 08 / 94$ & $12 / 09 / 94$ & \\
\hline Video Technology Laboratory & $11 / 08 / 94$ & & \\
\hline $\begin{array}{l}\text { Physical Separation of Neutron } \\
\text { Generators }\end{array}$ & $11 / 08 / 94$ & $01 / 26 / 95$ & \\
\hline $\begin{array}{l}\text { Mission Payload } 46 \text { and Ground } \\
\text { System Development and Testing }\end{array}$ & $11 / 14 / 94$ & $12 / 09 / 94$ & \\
\hline $\begin{array}{l}\text { Characterization Activities } \\
\text { Environmental Restoration }\end{array}$ & $11 / 15 / 94$ & & \\
\hline $\begin{array}{l}\text { Water Infiltration Test South } \\
\text { of Technical Area IV }\end{array}$ & $11 / 29 / 94$ & & \\
\hline $\begin{array}{l}\text { Site-Wide Hydrogeological } \\
\text { Characterization Surface Trenches }\end{array}$ & $11 / 23 / 94$ & & \\
\hline $\begin{array}{l}\text { Decontamination of Buildings } 828 \text {, } \\
834 \text {, and } 846\end{array}$ & $11 / 17 / 94$ & & \\
\hline Radiant Heat Tests CY95 & $11 / 18 / 94$ & $01 / 26 / 95$ & \\
\hline $\begin{array}{l}\text { Particle Beam Fusion Accelerator } \\
\text { Project }\end{array}$ & $11 / 18 / 94$ & & \\
\hline $\begin{array}{l}\text { Qualification Trials for General } \\
\text { Heat Source }\end{array}$ & $11 / 18 / 94$ & $12 / 12 / 94$ & \\
\hline
\end{tabular}


Table C-2. National Environmental Policy Act Documentation (Environmental Checklists/Action Description Memoranda) and Approval Status (Concluded)

\begin{tabular}{|c|c|c|c|}
\hline Title & $\begin{array}{l}\text { Memo to } \\
\text { DOE }\end{array}$ & $\begin{array}{l}\text { DOE } \\
\text { Approval }\end{array}$ & $\begin{array}{l}\text { DOE Request for } \\
\text { Environmental } \\
\text { Assessment }\end{array}$ \\
\hline $\begin{array}{l}\text { Air Force Technical Application } \\
\text { Center (AFTAC) Space Operations } \\
\text { Support }\end{array}$ & $11 / 18 / 94$ & & \\
\hline Neutron Generator Test Facility & $12 / 02 / 94$ & & \\
\hline $\begin{array}{l}\text { Surface Radiation Voluntary } \\
\quad \text { Corrective Measures (VCM) } \\
\text { Sites } 55,175,103,117,119, \\
\text { and } 193\end{array}$ & $12 / 01 / 94$ & $01 / 26 / 95$ & \\
\hline $\begin{array}{l}\text { DNA Robust Microelectronics } \\
\text { Radiation Harness }\end{array}$ & $12 / 12 / 94$ & $01 / 26 / 95$ & \\
\hline $\begin{array}{l}\text { Spectroscopic Excitation and } \\
\text { Classification of Trace Elements }\end{array}$ & $12 / 13 / 94$ & $01 / 26 / 95$ & \\
\hline Dielectric Sensor Development & $12 / 14 / 94$ & $01 / 26 / 95$ & \\
\hline $\begin{array}{l}\text { High-Voltage Initiation } \\
\text { Surveillance }\end{array}$ & $12 / 15 / 94$ & $12 / 19 / 94$ & \\
\hline $\begin{array}{l}\text { Ultra-Violet (UV) Spectroscopic } \\
\text { Detection and Identificaiton (ID) } \\
\text { of Food Pathogens }\end{array}$ & $12 / 15 / 94$ & $01 / 26 / 95$ & \\
\hline Warning-Sensor & $12 / 19 / 94$ & $02 / 03 / 95$ & \\
\hline Ground-Based Non-Nuclear Kill & $12 / 21 / 94$ & & \\
\hline
\end{tabular}

\section{REFERENCES}

National Environmental Policy Act (NEPA) of 1969, as amended. Title 42 U.S.C. 4321.

10 CFR 1021, 1992. "National Environmental Policy Act Implementing Procedures," as revised April 24, 1992. 


\section{APPENDIX D}

SAMPLE COLLECTION AND ANALYSIS 
D-2 


\section{CONTENTS}

$\underline{\text { Page }}$

D.1 Sample Collection for Terrestrial Surveillance $\ldots \ldots \ldots \ldots$ D-5

D.2 Sample Collecton for Air Quality Monitoring $\ldots \ldots \ldots \ldots$ D-5

D.3 External Penetrating Radiation $\ldots \ldots \ldots \ldots \ldots \ldots \ldots \ldots \ldots \ldots \ldots$

D.4 Sample Collection and Analysis for Groundwater Samples $\ldots \ldots \ldots$ D-5

D.5 Sample Collection and Analysis for Waste-Water Sampling . . . . . . . D-5

\section{TABLES}

D-1 Recommended Analytical Methods, Sample Containers, Preservation Techniques, and Holding Times . . . . . . . . . . . D-6

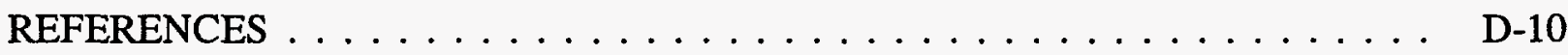


D-4 
This appendix lists sampling and analysis procedures and related documentation for each environmental medium. Table D-1 summarizes recommended analytical methods, sample containers, preservation techniques, and holding times.

\section{D.1 SAMPLE COLLECTION FOR TERRESTRIAL SURVEILLANCE}

Sample collection and analysis guidance for terrestrial surveillance is described in the Quality Assurance Program Plan (QAPP) and the Operating Procedure (OP) for terrestrial surveillance (SNL 1994a and 1994b).

\section{D.2 SAMPLE COLLECTION FOR AIR QUALITY MONITORING}

Sample collection and analysis guidance for air quality monitoring is described in the QAPP, the OP, and sampling plans for the National Emission Standards for Hazardous Air Pollutants (NESHAP) program, ambient air monitoring, and meteorological monitoring (SNL 1994c, 1994d; ITRI 1994).

\section{D.3 EXTERNAL PENETRATING RADIATION}

A dedicated set of environmental thermoluminescent dosimeters (TLDs) is maintained for this program. Procedures used in the SNL/NM environmental dosimetry program are documented in the dosimetry procedures manual (Thompson 1987; SNL 1994e).

\section{D.4 SAMPLE COLLECTION AND ANALYSIS FOR GROUNDWATER SAMPLES}

Sample collection and analysis guidance for groundwater monitoring is described in the QAPP, the OP, and sampling and analysis plans for groundwater sampling (Goodrich 1990; SNL 1990, 1992, 1993, 1994f, and 1994g).

\section{D.5 SAMPLE COLLECTION AND ANALYSIS FOR WASTE-WATER SAMPLING}

Complete documentation for the waste-water sampling program can be found in the wastewater monitoring program quarterly reports (IT 1993). These documents describe the methods and procedures used for the samples collected from the sampling locations (see Table 6-1 of Chapter 6). 
Table D-1. Recommended Analytical Methods, Sample Containers, Preservation Techniques, and Holding Times

\begin{tabular}{lcccc}
\hline Parameter & $\begin{array}{c}\text { Method No. } \\
(\text { SW-846) }\end{array}$ & $\begin{array}{c}\text { Estimated Method } \\
\text { Detection Limit }\end{array}$ & $\begin{array}{c}\text { Container } \\
\text { Type }^{\dagger}\end{array}$ & $\begin{array}{c}\text { Minimum } \\
\text { Volume }\end{array}$ \\
\hline
\end{tabular}

\section{Indicator Parameters}

pH

Specific Conductance

Total Organic Carbon (TOC)

Total Organic Halogens (TOX)

Groundwater Quality Parameters

\section{Chloride}

Phenols

Sulfate

Iron

Manganese

\section{0}

Modified 9050

9060

\section{NA}

NA

$1 \mathrm{mg} / \mathrm{L}$

$30 \mu \mathrm{g} / \mathrm{L}$

$1 \mathrm{mg} / \mathrm{L}$

$3 \mathrm{mg} / \mathrm{L}$

$10 \mu \mathrm{g} / \mathrm{L}$

$10 \mathrm{mg} / \mathrm{L}$

$0.5 \mathrm{mg} / \mathrm{L}$

$1 \mathrm{mg} / \mathrm{L}$

$5 \mathrm{mg} / \mathrm{L}$

$\begin{array}{ll}9038 \text { color } & 1 \mathrm{mg} / \mathrm{L} \\ \text { EPA } 300.0^{1} \mathrm{IC} & 5 \mathrm{mg} / \mathrm{L}\end{array}$

$6010 \mathrm{ICP} \quad 0.10 \mathrm{mg} / \mathrm{L}$

HNO to $\mathrm{pH}<2$

6 months
P, G

P, G

P, G

G, AG, Teflon-

lined cap

P, G

G, Teflon-

lined cap

P, G

$0.01 \mathrm{mg} / \mathrm{L}$
$50 \mathrm{~mL}$

$100 \mathrm{~mL}$

$4 \times 250 \mathrm{~mL}$

$4 \times 250 \mathrm{~mL}$

$50 \mathrm{~mL}$

$500 \mathrm{~mL}$

$50 \mathrm{~mL}$

$1000 \mathrm{~mL}$ "*

\section{NA}

NA

Cool to $4^{\circ} \mathrm{C}, \mathrm{HCL}$ or $\mathrm{HSO}$ to $\mathrm{pH}<2$

Cool to $4^{\circ} \mathrm{C}$,

HSO to $\mathrm{pH}<2$

None required

28 days

Cool to $4^{\circ} \mathrm{C}$, HSO to $\mathrm{pH}<4$

Cool to $4^{\circ} \mathrm{C}$

28 days

"U.S. Environmental Protection Agency, 1986, "Test Methods for Evaluating Solid Waste, Physical/Chemical Methods," Third Edition, EPA 530/SW-846, unless otherwise noted (EPA 1986). Color = Color metric technique; IC = ion chromatography; ICP = inductively coupled plasma spectroscopy; GFAA = graphite furnace atomic absorption; CVAA = cold vapor atomic absorption; GC = gas chromatography; IS = ion selective probe; and GC/MS = gas chromatography/mass spectrometry.

${ }^{\dagger}$ Method detection limit as listed for specified method. Detection limits listed as $\mathrm{mg} / \mathrm{L}=$ milligrams per liter; $\mu \mathrm{g} / \mathrm{L}=$ micrograms per liter; and $\mathrm{pCi} / \mathrm{L}=\mathrm{picocuries}$ per liter.

${ }^{\ddagger}$ Container types: $P=$ linear polyethylene; $\mathbf{G}=$ glass; and $\mathbf{A G}=$ amber glass.

Preservatives and holding times as specified in EPA-SW-846, Third Edition (EPA 1986).

IU.S. Environmental Protection Agency, 1984, "Methods for Chemical Analysis of Water and Wastewater," EPA-600-84-017 (EPA 1984).

"All metals analytes from single sample.

${ }^{\ddagger}$ All radionuclide analytes from single container.

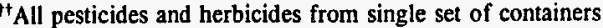




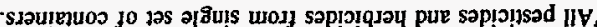

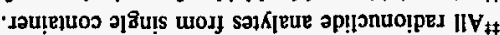

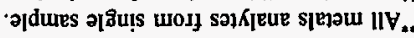

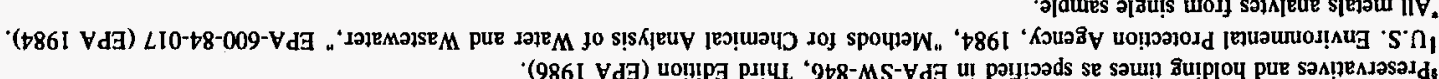

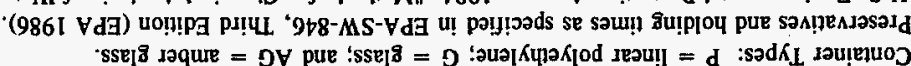

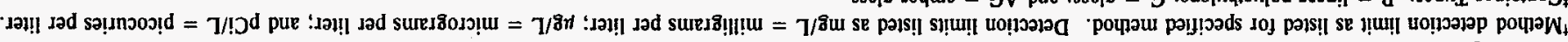

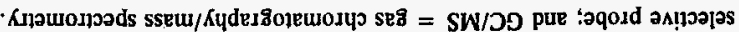

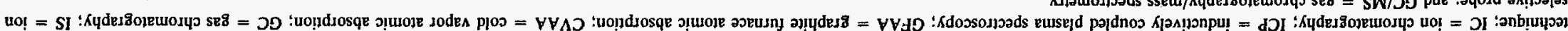

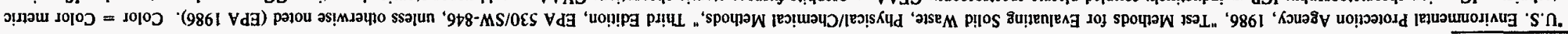

\begin{tabular}{|c|c|c|c|c|c|c|}
\hline supuou 9 & $\tau>H^{d}$ ol ONH & '188 I & d & $\mathrm{T} / ! \mathrm{O}^{\mathrm{d}} \mathrm{t}$ & 0IE6 & Eəg ssoID \\
\hline sipuour 9 & $\tau>H^{d}$ ol ONH & '108 1 & d & $T / 1 \supset^{d} \mathfrak{E}$ & $01 \varepsilon 6$ & Eudiv ssosp \\
\hline squour 9 & $Z>\mathrm{H}^{\mathrm{d}}$ ol ONH & .ך丁u 000' I & DV 'YIRG d & $\begin{array}{r}7 / 8 \mathrm{~m} 10^{\circ} 0 \\
\mathcal{T} / 8 \mathrm{su} 5000.0\end{array}$ & $\begin{array}{r}\text { dวI } 0109 \\
\forall \forall \unlhd \rho, Z Z L Z \forall d \exists\end{array}$ & гәм!!S \\
\hline sqpuow 9 & $\tau>H^{d} 01$ ONH & $.7 \mathrm{~T} 000$ I I & d & T/केแ $200^{\circ} 0$ & $\begin{array}{r}\text { dDI } 0109 \\
\forall \forall A D 0 † L L\end{array}$ & un!̣uə|əS \\
\hline $\begin{array}{l}\text { u! SKep } 8 E \\
\text { u! SKep EI }\end{array}$ & $\tau>H^{d}$ ol ONH & $.7^{\mathrm{W}} 000^{\mathrm{a}} \mathrm{I}$ & D d & $7 /$ శెu $2000^{\circ} 0$ & VYAD OLVL & KnOدW \\
\hline syjuour 9 & $\tau>H^{d}$ ol ONH &. $\mathrm{T}^{\mathrm{u}} 000^{\star} \mathrm{l}$ & d & $7 /$ ฮิu $500^{\circ}$ & VVHD IZヤL & реә7 \\
\hline $\begin{array}{l}\text { sppoour } 9 \\
\text { squoous } 9\end{array}$ & $\begin{array}{l}\tau>H^{d} \text { ol ONH } \\
\tau>H^{d} \text { ol ONH }\end{array}$ & $\begin{array}{l}. .7^{u x} 000^{\prime} I \\
.7^{u} 000^{\prime} I\end{array}$ & $\begin{array}{l}\text { d } \\
d\end{array}$ & 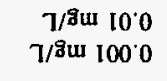 & $\begin{array}{r}\text { dDI } 0109 \\
\forall \forall A D 161 L\end{array}$ & 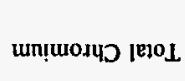 \\
\hline sqpuou 9 & $\tau>H^{d} 010 N H$ & $.7 \mathrm{Tu} 000^{\circ}$ & d & 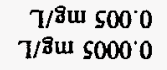 & $\begin{array}{r}\text { dDI } 0109 \\
\forall \forall \text { DD IEIL }\end{array}$ & wn!̣upeכ \\
\hline squoous 9 & $\tau>\mathrm{Hd}^{\mathrm{d}}$ ol ONH & $.7^{m} 000^{\prime} \mathrm{I}$ & d & $7 /$ /ืน $10 \%$ & dOI 0109 & un!ueg \\
\hline $\begin{array}{l}\text { sypuour } 9 \\
\text { sypuour } 9\end{array}$ & $\begin{array}{l}\tau>H^{d} \text { ol ONH } \\
\tau>H^{d} \text { ol ONH }\end{array}$ & $\begin{array}{l}.7^{\mathrm{w}} 000^{\prime} \mathrm{I} \\
.7^{\mathrm{w}} 000^{\prime} \mathrm{I}\end{array}$ & $\begin{array}{l}d \\
d\end{array}$ & $\begin{array}{l}T / 8 \mathrm{su} s 00^{\circ} 0 \\
T / 8 \mathrm{sw} s 00^{\circ} 0\end{array}$ & $\begin{array}{r}\text { dDI } 0109 \\
\forall \forall A D 090 L\end{array}$ & गุบวs. \\
\hline \multicolumn{7}{|c|}{ 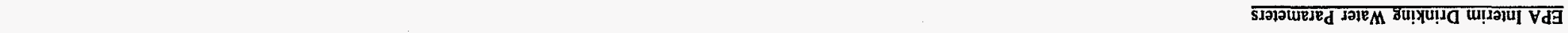 } \\
\hline squous 9 & $\tau>H^{d}$ ol ONH & I I & d & $7 /$ ใน 0 . 5 & dDI 0109 & un!pos \\
\hline $\begin{array}{l}\text { 8u!pioH } \\
\text { u!yeW }\end{array}$ & 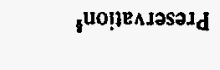 & $\begin{array}{l}\text { จunฺ० } \Lambda \\
\text { யnய!!! } W\end{array}$ & 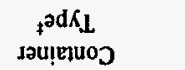 & 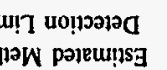 & $\begin{array}{l}\text { (9\$8-MS) } \\
\text { oN potpoW }\end{array}$ & دolauresed \\
\hline
\end{tabular}


Table D-1. Recommended Analytical Methods, Sample Containers, Preservation Techniques, and Holding Times (Continued)

\begin{tabular}{|c|c|c|c|c|c|c|}
\hline Parameter & $\begin{array}{l}\text { Method No. } \\
\text { (SW-846)" }\end{array}$ & $\begin{array}{l}\text { Estimated Method } \\
\text { Detection Limit }\end{array}$ & $\begin{array}{l}\text { Container } \\
\text { Type }^{\ddagger}\end{array}$ & $\begin{array}{c}\text { Minimum } \\
\text { Volume }\end{array}$ & Preservation & $\begin{array}{c}\text { Maximum } \\
\text { Hoiding Time }\end{array}$ \\
\hline Radium, total & 9315 & $3 \mathrm{pCi} / \mathrm{L}$ & P, G & 1 gal. & HNO to $\mathrm{pH}<2$ & 6 months \\
\hline Endrin & $8080 \mathrm{GC}$ & $0.10 \mu \mathrm{g} / \mathrm{L}$ & AG, Teflon-lined cap & $2 \times 1,000 \mathrm{~mL}^{++}$ & $\begin{array}{l}\text { Cool to } 4^{\circ} \mathrm{C} \text {, } \\
\text { pH 5-9 }\end{array}$ & $\begin{array}{l}7 \text { days to extraction, } \\
40 \text { days after } \\
\text { extraction }\end{array}$ \\
\hline Lindane ( $q-B H C)$ & $8080 \mathrm{GC}$ & $0.05 \mu \mathrm{g} / \mathrm{L}$ & AG, Teflon-lined cap & $2 \times 1,000 \mathrm{~mL}^{\dagger+}$ & $\begin{array}{l}\text { Cool to } 4^{\circ} \mathrm{C} \text {. } \\
\text { pH 5-9 }\end{array}$ & $\begin{array}{l}7 \text { days to extraction, } \\
40 \text { days after } \\
\text { extraction }\end{array}$ \\
\hline Methoxychlor & 8080 GC & $0.5 \mu \mathrm{g} / \mathrm{L}$ & AG, Teflon-lined cap & $2 \times 1.000 \mathrm{~mL}^{\dagger t}$ & $\begin{array}{l}\text { Cool to } 4^{\circ} \mathrm{C} \text {, } \\
\text { pH 5-9 }\end{array}$ & $\begin{array}{l}7 \text { days to extraction, } \\
40 \text { days after } \\
\text { extraction }\end{array}$ \\
\hline Toxaphene & 8080 GC & $1.0 \mu \mathrm{g} / \mathrm{L}$ & AG, Teflon-lined cap & $2 \times 1,000 \mathrm{~mL}^{\dagger \dagger}$ & $\begin{array}{l}\text { Cool to } 4^{\circ} \mathrm{C} \text {, } \\
\text { pH 5-9. }\end{array}$ & $\begin{array}{l}7 \text { days to extraction, } \\
40 \text { days after } \\
\text { extraction }\end{array}$ \\
\hline 2,4-D & $8150 \mathrm{GC}$ & $20 \mu \mathrm{g} / \mathrm{L}$ & AG, Teflon-lined cap & $2 \times 1,000 \mathrm{~mL}^{\dagger+}$ & $\begin{array}{l}\text { Cool to } 4^{\circ} \mathrm{C} \text {, } \\
\text { pH 5-9 }\end{array}$ & $\begin{array}{l}7 \text { days to extraction, } \\
40 \text { days after } \\
\text { extraction }\end{array}$ \\
\hline 2,4,5-TP Silvex & $8150 \mathrm{GC}$ & $10 \mu \mathrm{g} / \mathrm{L}$ & $\begin{array}{l}\text { AG, Teflon-lined cap } \\
\text { pH 5-9 }\end{array}$ & $2 \times 1,000 \mathrm{~mL}^{\dagger t}$ & Cool to $4^{\circ} \mathrm{C}$, & $\begin{array}{l}7 \text { days to extraction, } \\
40 \text { days after } \\
\text { extraction }\end{array}$ \\
\hline \multicolumn{7}{|c|}{ 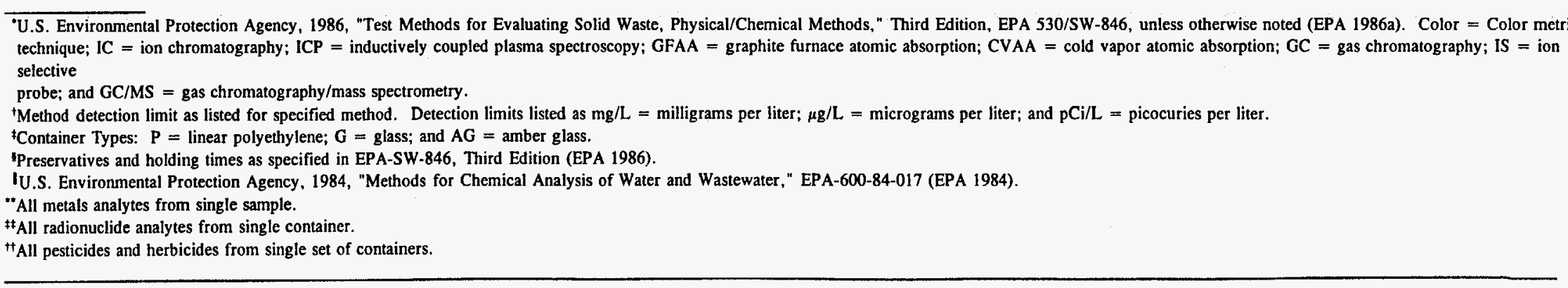 } \\
\hline
\end{tabular}




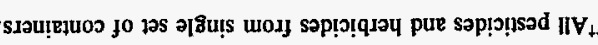

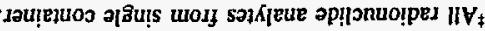

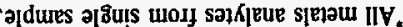

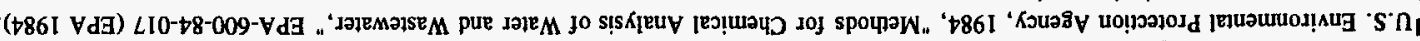

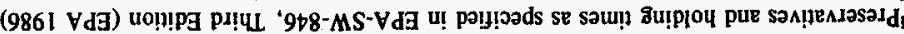

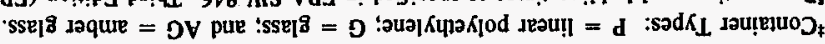

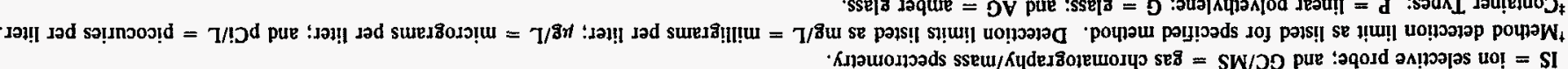

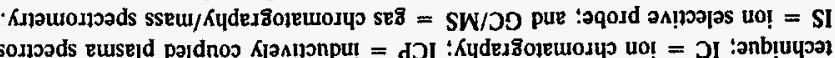

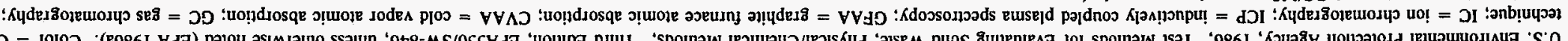

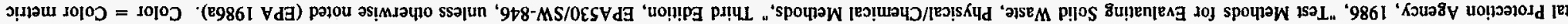

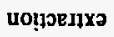

selje SKeP Ot

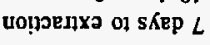
O. 011000
188 I $x$ I 70
เอร

ov

T/8ิ

SWOD $0\llcorner 28$

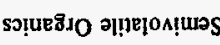

sKep pI

euoụdo 7כH sdosp

$T^{\mathrm{w}}$ op $\times \varepsilon$

midas paut|-uofjal'0

$7 / 81100 I^{-5}$

SWวอ 0ฤZ8

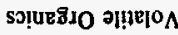

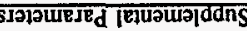

งบ 9

ว.t 011000

Tur $00 z$

(paz!!!บวเs) D/d

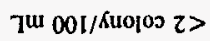

zE16

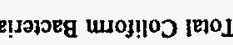

Sर́E $8 Z \quad$ OSH $\tau>\mathrm{H}^{\mathrm{d}} \mathrm{O}$

ग4 8t Jot 011003

$7 \mathrm{q} 00$

ך 001

D.d

7/มิน โ 0

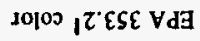

JI $0^{\circ} 00 E \forall d \exists$

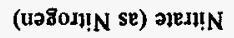

5485

Jot on joos

7u 002

ก.LN I>

I $1081 \mathrm{VdG}$

Ku!p!qunI

SKEp $8 Z$

pasịnbas auoN

ๆய $00 E$

7/ริแ โ 0

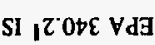

ગI $0^{\circ} 00 \varepsilon \forall d 9$

op!ronte

\begin{tabular}{|c|c|c|c|c|c|c|}
\hline 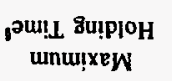 & 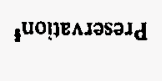 & 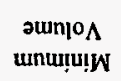 & 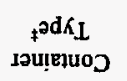 & 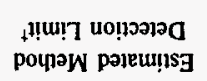 & $\begin{array}{c}\text { (9t8-MS) } \\
\text { ON poपागW }\end{array}$ & 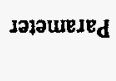 \\
\hline
\end{tabular}

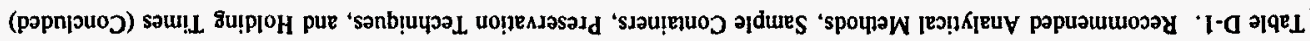




\section{REFERENCES}

EPA 1984: U.S. Environmental Protection Agency, "Methods for Chemical Analysis of Water and Waste Water, " EPA-600-84-017, EPA, Washington, DC (1984).

EPA 1986: U.S. Environmental Protection Agency, "Test Methods for Evaluating Solid Waste, Physical/Chemical Methods, Third Edition," EPA-SW-846, EPA, Washington, DC (1986).

Goodrich 1990: Goodrich, M. T., "A Technical Procedure for the Measurement of Static Water Levels in Groundwater Monitor Wells, " SOP 90-02, Sandia National Laboratories, Albuquerque, NM (1990).

IT 1993: IT Corporation, "Groundwater Protection Program, Ground-Water Surveillance Task, Sampling and Analysis Plan, " prepared for Sandia National Laboratories, Albuquerque, NM (March 1993).

ITRI 1994: Inhalation Toxicology Research Institute, "Confirmatory Measurements of Airborne Radionuclides Emitted from Facilities at Sandia National Laboratories Technical Area V: Report for NESHAP Compliance," ITRI 940603, Albuquerque, NM (1994).

SNL 1990: Sandia National Laboratories, "Groundwater Quality Assessment Program for the Sandia Chemical Waste Landfill," prepared by A. M. Parsons, Sandia National Laboratories, Albuquerque, NM (1990).

SNL 1992: Sandia National Laboratories, "Sampling and Analysis Plan for Groundwater Assessment Monitoring at the Chemical Waste Landfill, " Revision 4.0, Appendix G in Sandia National Laboratories, New Mexico, 1992, "Chemical Waste Landfill Final Closure Plan and Postclosure Permit Application," Volume 2-Appendices, Environmental Restoration Program, Sandia National Laboratories, Albuquerque, NM (1992).

SNL 1993: Sandia National Laboratories, "Sitewide Groundwater Monitoring Program Sampling and Analysis Plan," draft, Sandia National Laboratories, Albuquerque, NM (1993).

SNL 1994a: Sandia National Laboratories, "Quality Assurance Project Plan for Terrestrial Surveillance at Sandia National Laboratories, New Mexico," QUA94-04, Sandia National Laboratories, NM (1994).

SNL 1994b: Sandia National Laboratories, "Terrestrial Surviellance Operating Procedures," FOP95-03, Sandia National Laboratories, NM (1994). 
SNL 1994c: Sandia National Laboratories, "National Emission Standards for Hazardous Air Pollutants (NESHAP) Radionuclide Quality Assurance Program Plan for SNL/NM (40 CFR Part 61, Subpart H), " QUA94-07, Sandia National Laboratories, NM (1994).

SNL 1994d: Sandia National Laboratories, "Quality Assurance Project Plan for Meteorological and Ambient Air Monitoring Program," QUA94-03, Sandia National Laboratories, NM (1994).

SNL 1994e: Sandia National Laboratories, "Environmental Dosimetry Processing," Personnel Radiation Dosimetry Program (PRDP)-30-04, Sandia National Laboratories, Albuquerque, NM (April 21, 1994).

SNL 1994f: Sandia National Laboratories, "Sampling and Analysis Plan for Groundwater Detection Monitoring at the Mixed Waste Landfill," draft, Rev. 1.0, Sandia National Laboratories, Albuquerque, NM (1994).

SNL 1994g: Sandia National Laboratories, "Site-Specific Sampling and Analysis Plan, TA-II Groundwater Monitoring," Sandia National Laboratories, Albuquerque, NM (1994).

Thompson 1987: Thompson, D. J., "Description and Procedures of the Environmental Radiation Dosimetry Program," SAND87-1916, Sandia National Laboratories, Albuquerque, NM (August 1987).

40 CFR 61, 1973. "National Emission Standards for Hazardous Air Pollutants (NESHAP), " including 1985, Subpart H. "National Emission Standards for Emissions of Radionuclides Other Than Radon From Department of Energy Facilities," as amended. 
APPENDIX E

MINIMUM DETECTION LIMITS 
E-2 


\section{CONTENTS}

TABLE

$\underline{\text { Page }}$

E-1 Detection Limits for Selected Radiochemical Analysis $\ldots \ldots \ldots$ E-5

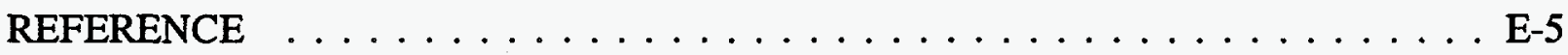


E-4 
Table E-1. Detection Limits for Selected Radiochemical Analysis

\begin{tabular}{|c|c|c|c|c|}
\hline \multirow[b]{2}{*}{ Analysis } & \multicolumn{2}{|c|}{ Sample } & \multirow[b]{2}{*}{ Detection Limit } & \multirow[b]{2}{*}{ Count Time } \\
\hline & Media & Minimum Size & & \\
\hline \multirow[t]{3}{*}{ Tritium } & Water & $10 \mathrm{~mL}$ & $0.3 \mathrm{pCi} / \mathrm{mL}$ & $125 \mathrm{~min}$ \\
\hline & Vegetation & $10 \mathrm{~mL}^{*}$ & $0.3 \mathrm{pCi} / \mathrm{mL}^{*}$ & $125 \mathrm{~min}$ \\
\hline & Soil & $10 \mathrm{~mL}^{*}$ & $0.3 \mathrm{pCi} / \mathrm{mL}^{*}$ & $125 \mathrm{~min}$ \\
\hline \multirow[t]{2}{*}{ Uranium, total } & Water & $100 \mathrm{~mL}$ & $0.002 \mathrm{mg} / \mathrm{L}$ & NA \\
\hline & Soil & $100 \mathrm{~g}$ & $0.1 \mu \mathrm{g} / \mathrm{g}$ & NA \\
\hline Gross Alpha & Water & $100 \mathrm{~mL}$ & $3 \mathrm{pCi} / \mathrm{L}$ & $100 \mathrm{~min}$ \\
\hline Gross Beta & Water & $100 \mathrm{~mL}$ & $4 \mathrm{pCi} / \mathrm{L}$ & $100 \mathrm{~min}$ \\
\hline Gamma Spectral $^{\dagger}$ & -- & -- & -- & -- \\
\hline
\end{tabular}

Source: American National Standards Institute (ANSI 1989).

Note: $\mathrm{mL}=$ milliliter; $\mathrm{pCi} / \mathrm{mL}=$ picocuries per milliliter; $\mathrm{min}=$ minute;

$\mathrm{mg} / \mathrm{L}=$ milligrams per liter; $\mathrm{NA}=$ not applicable; $\mathrm{g}=\mathrm{gram} ; \mu \mathrm{g} / \mathrm{g}=$ micrograms per gram.

*Extracted water.

'Detection limit and required sample size vary depending on radionuclide and media of interest.

\section{REFERENCE}

ANSI 1989: American National Standards Institute, "Performance Criteria for Radiobioassay," ANSI-N13.30-DRAFT-89, ANSI, New York, NY (1989). 


\section{APPENDIX F}

QUALITY ASSURANCE DATA 
F-2 


\section{CONTENTS}

TABLES

Page

F-1 Analytical Laboratories Used by SNL/NM in $1994 \ldots \ldots \ldots \ldots$ F-5

F-2 Sample Variability in Replicate Water Samples and Blanks, $1994 \ldots \ldots$. . . F-6

F-3 Sample Variability in Replicate Vegetation Samples, $1994 \ldots \ldots$. . . . . F F-7

F-4 Sample Variability in Replicate Soil and Sediment Samples, $1994 \ldots \ldots$. . . F-8

F-5 1994 Quality Assurance Results for Selected Radiochemical

Analysis Environmental Protection Agency/Accu-Labs Research,

Inc., Intercomparison Study, Cross-Check Results . . . . . . . . . . . F-9

F-6 U.S. Department of Energy Operational Safety, Health and

Environment Division, Quality Assessment Program,

Accu-Labs Research, Inc., Results . . . . . . . . . . . . . . . . . . . F-10 
F-4 
Table F-1. Analytical Laboratories Used by SNL/NM in 1994

Accu-Labs Research, Inc.

Environmental Control Technology Corporation (ENCOTEC)

Enseco-Rocky Mountain Analytical Laboratory (RMAL)

Quantia

Southern Methodist University

Sandia National Laboratories/New Mexico (SNL/NM)

Texas Bureau of Economic Geology

TMA/Eberline

University of Texas 
Table F-2. Sample Variability in Replicate Water Samples and Blanks, 1994

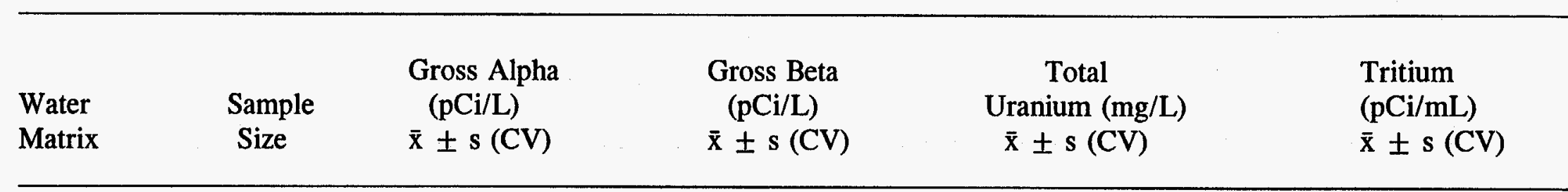

\section{May 1994}

Station 11

Solution

Total

$3 \quad 2.0 \pm 0.0(0)$

$3 \cdot 5.3 \pm 3.1(57)$

Blank

$3 \quad 0.7 \pm 0.6(87)$
$4.3 \pm 1.5(35)$
$10.0 \pm 2.6(26)$

á

August 1994

$2.7 \pm 2.9(108)$

$$
\begin{array}{cc}
0.0018 \pm 0.0004(22) & 0.08 \pm 0.02(25) \\
0.0020 \pm 0.0003(16) & 0.15 \pm 0.11(70) \\
& -0.10 \pm 0.02(-24)
\end{array}
$$

Station 11

Solution

$\begin{array}{lrr}3 & 4.0 \pm 1.0(25) & 9.3 \pm 4.0(43) \\ 3 & 11.7 \pm 3.1(26) & 20.3 \pm 2.1(10) \\ 3 & 0.3 \pm 0.6(173) & 1.0 \pm 1.0(100)\end{array}$
$0.0025 \pm 0.0001(5)$
$0.0029 \pm 0.0004$ (13)

$0.08 \pm 0.05(66)$

$0.20 \pm 0.07$ (36)

Blank

$11.7 \pm 3.1(26)$
$0.3 \pm 0.6(173)$

$1.0 \pm 1.0(100)$

$0.07 \pm 0.07$ (105)

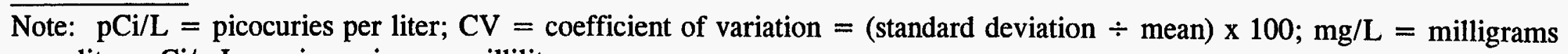
per liter; $\mathrm{pCi} / \mathrm{mL}=$ picocuries per milliliter.

"Less than minimum detection limit. 
Table F-3. Sample Variability in Replicate Vegetation Samples, 1994

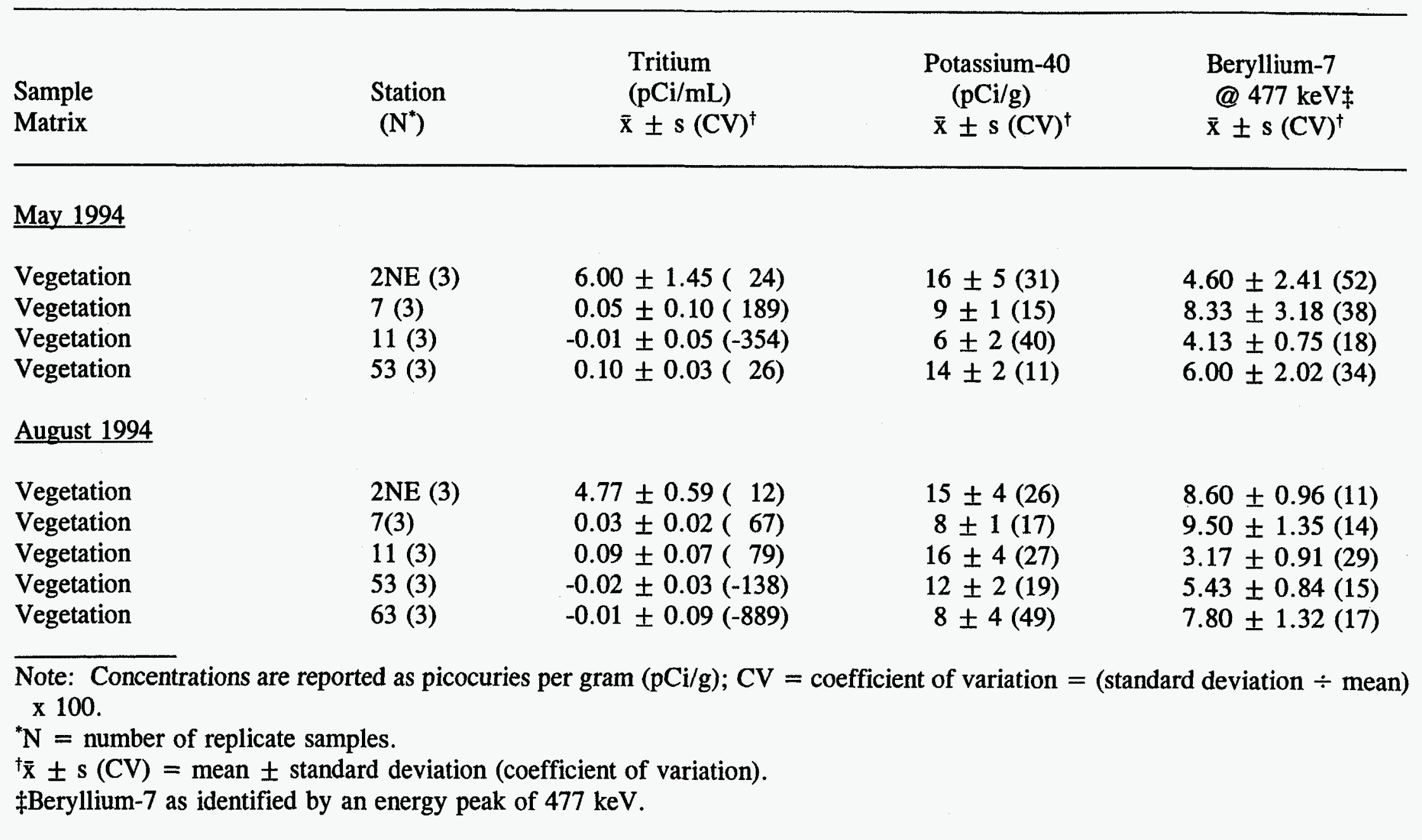


Table F-4. Sample Variability in Replicate Soil and Sediment Samples, 1994

\begin{tabular}{lccccc}
\hline & Total Uranium & Tritium & Cesium-137 & Potassium-40 \\
$(\mathrm{pCi} / \mathrm{g})$ & $(\mathrm{pCi} / \mathrm{g})$ \\
Sample & Station & $(\mu \mathrm{g} / \mathrm{L})$ & $(\mathrm{pCi} / \mathrm{mL})$ & $\overline{\mathrm{x}} \pm \mathrm{s}(\mathrm{CV})^{\dagger}$ & $\overline{\mathrm{x}} \pm \mathrm{s}(\mathrm{CV})^{\dagger}$ \\
Matrix & $\left(\mathrm{N}^{*}\right)$ & $\overline{\mathrm{x}} \pm \mathrm{s}(\mathrm{CV})^{\dagger}$ & $\overline{\mathrm{x}} \pm \mathrm{s}(\mathrm{CV})^{\dagger}$ & \\
\hline
\end{tabular}

\section{$\underline{\text { May } 1994}$}

\begin{tabular}{|c|c|c|c|c|c|}
\hline Soil & $2 \mathrm{NE}(3)$ & $0.73 \pm 0.46(63)$ & $33.67 \pm 2.52(7)$ & $0.20 \pm 0.03(13)$ & $17 \pm 1(3)$ \\
\hline Soil & $7(3)$ & $1.27 \pm 0.15(12)$ & $0.08 \pm 0.08(109)$ & $0.99 \pm 0.11(11)$ & $19 \pm 1(3)$ \\
\hline Soil & $11(3)$ & $1.30 \pm 0.10(8)$ & $0.20 \pm 0.17(85)$ & $0.03 \pm 0.05(148)$ & $19 \pm 1(6)$ \\
\hline Soil & $53(3)$ & $1.47 \pm 0.12(8)$ & $0.89 \pm 0.65(73)$ & $0.10 \pm 0.02(20)$ & $17 \pm 1(3)$ \\
\hline Sediment & $11(3)$ & $2.33 \pm 0.15(7)$ & $0.02 \pm 0.02(139)$ & $0.19 \pm 0.07(36)$ & $17 \pm 3(16)$ \\
\hline Sediment & $73(3)$ & $1.87 \pm 0.21(11)$ & $0.06 \pm 0.05(81)$ & $0.05 \pm 0.01(11)$ & $12 \pm 4(33)$ \\
\hline \multicolumn{6}{|c|}{ August 1994} \\
\hline Soil & $2 \mathrm{NE}(3)$ & $1.40 \pm 0.26(19)$ & $17.67 \pm 2.08(12)$ & $0.17 \pm 0.01(7)$ & $18 \pm 1(3)$ \\
\hline Soil & $7(3)$ & $2.47 \pm 0.15(6)$ & $0.09 \pm 0.08(87)$ & $0.51 \pm 0.16(31)$ & $18 \pm 0(0)$ \\
\hline Soil & $11(3)$ & $1.27 \pm 0.29(23)$ & $0.14 \pm 0.05(33)$ & $0.07 \pm 0.03(43)$ & $18 \pm 1(6)$ \\
\hline Soil & $53(3)$ & $1.83 \pm 0.15(8)$ & $1.54 \pm 2.48(161)$ & $0.11 \pm 0.02(14)$ & $17 \pm 1(7)$ \\
\hline Soil & $63(3)$ & $3.50 \pm 1.13(32)$ & $0.72 \pm 0.57(79)$ & $0.86 \pm 0.13(15)$ & $13 \pm 2(13)$ \\
\hline Sediment & $11(3)$ & $1.77 \pm 0.06$ & $0.11 \pm 0.08(75)$ & $0.35 \pm 0.05(14)$ & $16 \pm 1(7)$ \\
\hline Sediment & $73(3)$ & $1.63 \pm 0.49(30)$ & $0.13 \pm 0.05(38)$ & $0.00 \pm 0.02(458)$ & $21 \pm 2(8)$ \\
\hline
\end{tabular}

Note: $\mathrm{CV}=$ coefficient of variation $=($ standard deviation $\div$ mean $) \times 100$

${ }^{*} \mathrm{~N}=$ number of replicate samples.

${ }^{\dagger} \overline{\mathrm{X}} \pm \mathrm{s}(\mathrm{CV})=$ mean \pm standard deviation (coefficient of variation). 
Table F-5. 1994 Quality Assurance Results for Selected Radiochemical Analysis Environmental Protection Agency/Accu-Labs Research, Inc., Intercomparison Study, Cross-Check Results

\begin{tabular}{|c|c|c|c|c|c|}
\hline Month & $\begin{array}{c}\text { EPA Result } \\
(\mathrm{pCi} / \mathrm{L} \pm 3 \text { sigma })\end{array}$ & $\begin{array}{l}\text { Accu-Labs Results } \\
\text { (pCi/L } \pm 2 \text { sigma) }\end{array}$ & $\begin{array}{c}\text { Deviation From Known } \\
\text { (sigma) }\end{array}$ & $\begin{array}{l}\text { Grand } \\
\text { Average }\end{array}$ & $\begin{array}{c}\text { Deviation from Grand } \\
\text { Average }\end{array}$ \\
\hline \multicolumn{6}{|c|}{ Gross Alpha in Water } \\
\hline 10/1994 (Blind) & $57.0 \pm 14.0$ & $50 \pm 1 ; 56 \pm 1 ; 56 \pm 1$ & -0.37 & 56.68 & -0.33 \\
\hline $10 / 1994$ & $57.0 \pm 14.0$ & $51 \pm 7 ; 56 \pm 7 ; 53 \pm 7$ & -0.45 & 52.30 & 0.13 \\
\hline $7 / 1994$ & $32.0 \pm 8.0$ & $37 \pm 8 ; 42 \pm 6 ; 40 \pm 5$ & 1.66 & 29.74 & 2.15 \\
\hline 4/1994 (Blind) & $86.0 \pm 22.0$ & $87 \pm 8 ; 78 \pm 9 ; 84 \pm 8$ & -0.24 & 84.40 & -0.11 \\
\hline $1 / 1994$ & $15.0 \pm 5.0$ & $14 \pm 4 ; 14 \pm 4 ; 11 \pm 4$ & -0.69 & 13.75 & -0.26 \\
\hline \multicolumn{6}{|c|}{ Gross Beta in Water } \\
\hline 10/1994 (Blind) & $142.0 \pm 21.0$ & $124 \pm 2 ; 119 \pm 2 ; 114 \pm 2$ & -1.90 & 125.57 & -0.54 \\
\hline $10 / 1994$ & $23.0 \pm 5.0$ & $21 \pm 5 ; 22 \pm 5 ; 21 \pm 5$ & -0.58 & 27.16 & -2.02 \\
\hline $6 / 1994$ & $10.0 \pm 5.0$ & $16 \pm 3 ; 14 \pm 3 ; 13 \pm 3$ & 1.50 & 14.91 & -0.20 \\
\hline 4/1994 (Blind) & $117.0 \pm 18.0$ & $98 \pm 6 ; 96 \pm 6 ; 94 \pm 6$ & -2.02 & 106.86 & -1.04 \\
\hline $1 / 1994$ & $62.0 \pm 10.0$ & $50 \pm 6 ; 53 \pm 6 ; 46 \pm 6$ & -2.14 & 56.14 & -1.12 \\
\hline \multicolumn{6}{|c|}{ Uranium in Water } \\
\hline 10/1994 (Blind) & $20.0 \pm 3.0$ & $19.8 ; 20.1 ; 17.8$ & -0.44 & 19.64 & -0.23 \\
\hline $9 / 1994$ & $35.0 \pm 3.0$ & $33.3 ; 35.6 ; 35.0$ & -0.21 & 34.24 & 0.23 \\
\hline $6 / 1994$ & $52.6 \pm 5.3$ & $52.9 ; 52.9 ; 47.4$ & -0.50 & 51.08 & 0.00 \\
\hline 4/1994 (Blind) & $25.0 \pm 3.0$ & $28.3 ; 29.6 ; 26.9$ & 1.89 & 24.39 & 2.24 \\
\hline $2 / 1994$ & $10.1 \pm 3.0$ & $10.7 ; 10.7 ; 10.7$ & 0.35 & 9.64 & 0.61 \\
\hline \multicolumn{6}{|c|}{ Tritium in Water and Urine } \\
\hline $8 / 1994$ & $9951 \pm 995$ & $\begin{array}{c}10500 \pm 400 ; 10900 \pm 400 ; 10200 \\
\pm 400\end{array}$ & 1.01 & 9651.86 & 1.53 \\
\hline $3 / 1994$ & $4936 \pm 494$ & $\begin{array}{c}4970 \pm 250 ; 4980 \pm 250 ; 4990 \pm \\
250\end{array}$ & 0.16 & 4844.97 & 0.47 \\
\hline
\end{tabular}


Table F-6. U.S. Department of Energy Operational Safety, Health and Environment Division, Quality Assessment Program (QAP), Accu-Labs Research, Inc., Results

\begin{tabular}{|c|c|c|c|}
\hline \multirow[b]{2}{*}{ Radionuclide } & \multicolumn{3}{|c|}{ QAP XXXIX - 9309} \\
\hline & ALR Result & EML Result & Ratio ALR/EML \\
\hline \multicolumn{4}{|l|}{ Vegetation $(\mathrm{Bg} / \mathrm{kg})^{*}$} \\
\hline $\begin{array}{l}\text { Pu-239 } \\
\text { Pu-239 } \\
\text { Pu-238 } \\
\text { U-238 } \\
\text { Am-241 } \\
\text { Sr-90 } \\
\text { Cs-137 } \\
\text { H-3 } \\
\text { K-40 } \\
\text { Co-60 }\end{array}$ & $\begin{array}{c}1.74 \pm 1.24 \\
\S \\
0.687 \pm 0.386 \\
\ddagger \\
1.26 \pm 0.67 \\
554 \pm 8 \\
166 \pm 11 \\
\ddagger \\
860 \pm 60 \\
9.86 \pm 1.42\end{array}$ & $\begin{array}{c}1.25 \pm 0.150 \\
\S \\
0.0917 \pm 0.026 \\
\ddagger \\
0.816 \pm 0.074 \\
535 \pm 121 \\
148 \pm 2.6 \\
\ddagger \\
808 \pm 12.8 \\
10.7 \pm 0.287\end{array}$ & $\begin{array}{c}1.39 \\
\S \\
7.49 \\
\ddagger \\
1.54 \\
1.04 \\
1.12 \\
\ddagger \\
1.06 \\
0.92\end{array}$ \\
\hline \multicolumn{4}{|l|}{ Water $(\mathrm{Bg} / \mathrm{L})^{\dagger}$} \\
\hline $\begin{array}{l}\text { Pu-239 } \\
\text { Pu-239 } \\
\text { Pu-238 } \\
\text { U-234 } \\
\text { U-238 } \\
\text { Am-241 } \\
\text { Sr-90 } \\
\text { Cs-137 } \\
\text { H-3 } \\
\text { Mn-54 } \\
\text { Co-60 } \\
\text { Cs-134 } \\
\text { Cs-144 }\end{array}$ & $\begin{array}{c}0.612 \pm 0.114 \\
\S \\
0.961 \pm 0.112 \\
1.09 \pm 0.10 \\
1.12 \pm 0.10 \\
1.02 \pm 0.12 \\
62.2 \pm 2.6 \\
55.1 \pm 4.8 \\
120 \pm 6 \\
115 \pm 7 \\
369 \pm 12 \\
57.5 \pm 3.8 \\
482 \pm 48\end{array}$ & $\begin{array}{c}0.602 \pm 0.063 \\
\S \\
1.06 \pm 0.095 \\
1.11 \pm 0.013 \\
1.11 \pm 0.047 \\
1.01 \pm 0.056 \\
68.6 \pm 3.25 \\
46.6 \pm 1.07 \\
113 \pm 7.0 \\
108 \pm 2.0 \\
317 \pm 6.12 \\
53.0 \pm 1.23 \\
491 \pm 4.44\end{array}$ & $\begin{array}{l}1.02 \\
\S \\
0.91 \\
0.98 \\
1.01 \\
1.01 \\
0.91 \\
1.18 \\
1.06 \\
1.06 \\
1.16 \\
1.08 \\
0.98\end{array}$ \\
\hline \multicolumn{4}{|c|}{$\begin{array}{l}\text { Note: ALR = Accu-Labs Research; EML = Environmental Measurements Laboratory. } \\
\text { "Units and results are as reported by DOE QAP. To convert to picocuries per gram (pCi/g), multiply } \\
\text { Becquerels per kilogram (Bq/kg) by } 0.37 \text {. } \\
{ }^{\dagger} \text { Units and results are as reported by DOE QAP. To convert to picocuries per liter (pCi/L), multiply by } \\
\text { Becquerels per liter (Bq/L) } 3.7 \times 10 . \\
=\text { not requested. } \\
\$=\text { no result. }\end{array}$} \\
\hline
\end{tabular}


Table F-6. U.S. Department of Energy Operational Safety, Health and Environment Division, Quality Assessment Program (QAP), Accu-Labs Research, Inc., Results (Concluded)

QAP XXXIX - 9309

$\underline{\text { Soil }(\mathrm{Bg} / \mathrm{kg})^{*}}$

Pu-239

Pu-239

U-234

$\mathrm{U}-234$

U-238

U-238

Am-241

Sr-90

Cs-137

H-3

K-40

\section{$13.8 \pm 5.7$}

$\S$

$23.4 \pm 1.8$

$\S$

$21.5 \pm 1.7$

$\S$

$1.56 \pm 1.00$

$2.49 \pm 0.78$

$295 \pm 12$

$\ddagger$

$356 \pm 21$

$$
\begin{gathered}
7.78 \pm 0.35 \\
\S \\
32.6 \pm 0.779 \\
\S \\
33.0 \pm 2.41 \\
\S \\
1.73 \pm 0.047 \\
3.30 \pm 0.330 \\
280 \pm 4.87 \\
\ddagger
\end{gathered}
$$$$
428 \pm 34.5
$$

1.77

$\S$

0.72

$\S$

0.65

$\S$

0.90

0.76

1.05

$\ddagger$

0.83

Note: ALR = Accu-Labs Research; EML = Environmental Measurements Laboratory.

"Units and results are as reported by DOE QAP. To convert to picocuries per gram ( $\mathrm{pCi} / \mathrm{g}$ ), multiply

Becquerels per kilogram $(\mathrm{Bq} / \mathrm{kg})$ by 0.37 .

'Units and results are as reported by DOE QAP. To convert to picocuries per liter ( $\mathrm{pCi} / \mathrm{L})$, multiply by

Becquerels per liter $(\mathrm{Bq} / \mathrm{L}) 3.7 \times 10$.

$\ddagger=$ not requested.

$\S=$ no result. 
APPENDIX G

ENVIRONMENTAL REGULATIONS AND STANDARDS 
G-2 


\section{CONTENTS}

Page

G.1 INTRODUCTION $\ldots \ldots \ldots \ldots \ldots \ldots \ldots \ldots \ldots \ldots \ldots$

\section{TABLES}

G-1 Derived Concentration Guides (DCGs) For Selected Radionuclides . . . . . G-6

G-2 Radiation Standards for Protection of the Public in the Vicinity of U.S. Department of Energy Facilities

G-3 Groundwater Monitoring Parameters Required by 40 CFR 265, Subpart F ............................. G

G-4 U.S. Environmental Protection Agency Interim Primary DrinkingWater Supply Parameters 
G-4 


\section{G.1 INTRODUCTION}

Radiation-protection standards for the public have been established by the U.S. Department of Energy (DOE) to protect public health. This is accomplished by limiting radiation doses (resulting from DOE operations) received by individuals residing in uncontrolled areas. These standards are based on the risk to members of the public. Environmental monitoring requirements for DOE operations are established in DOE Order 5400.1, General Environmental Protection Program (DOE 1988). Radiation protection standards are provided in DOE Order 5400.5, General Radiation Protection of the Public and the Environment (DOE 1990). DOE Order 5400.5 limits the annual effective dose equivalent (EDE) to any member of the public to 100 millirems per year (mrem/yr). This annual EDE should be estimated based on all DOE emission sources and all exposure pathways. DOE Order 5400.5 also contains the derived concentration guide (DCG) for concentrations of radionuclides in water and air that could be continuously consumed or inhaled (365 days/year) and not exceed the DOE primary radiation protection standard of $100 \mathrm{mrem} / \mathrm{yr}$ EDE. Table G-1 contains the DCGs pertinent to Sandia National Laboratories/New Mexico (SNL/NM) activities and to this report.

DOE facilities are also required to comply with U.S. Environmental Protection Agency (EPA) standards for radiation protection. On December 15, 1989, the EPA issued its final rule on National Emission Standards for Hazardous Air Pollutants (NESHAP) for radionuclides. This rule mandates that air emissions from DOE facilities shall not cause any individual of the public to receive in any year an EDE of greater than 10 mrem/year. Table G-2 summarizes the public radiation protection standards that are applicable to DOE facilities. In addition to these quantitative standards, the overriding DOE policy is that exposures to the public shall be maintained as low as reasonably achievable (ALARA).

Table G-3 lists the 40 CFR 265, Subpart F, parameters required for groundwater-monitoring analysis. Table G-4 shows the EPA interim primary drinking-water standards (40 CFR 265, Appendix III) for the groundwater-monitoring parameters. 
Table G-1. Derived Concentration Guides (DCGs) For Selected Radionuclides*

\begin{tabular}{|c|c|c|c|c|}
\hline \multirow[b]{2}{*}{ Nuclide } & \multicolumn{2}{|c|}{ Drinking Water } & \multicolumn{2}{|c|}{ Inhaled $\mathrm{Air}^{\dagger}$} \\
\hline & $\begin{array}{l}\text { DCG } \\
(\mu \mathrm{Ci} / \mathrm{L})\end{array}$ & $\begin{array}{c}\mathrm{f}, \\
\text { Value }\end{array}$ & $\begin{array}{c}\text { DCG } \\
\left(\mu \mathrm{Ci} / \mathrm{m}^{3}\right)\end{array}$ & $\begin{array}{l}\text { Solubility } \\
\text { Class }\end{array}$ \\
\hline Tritium (water) & $2 \mathrm{E}+00$ & -- & $1 E-01$ & -- \\
\hline Cesium-137 & $3 E-03$ & $1 E+00$ & 4E-04 & D \\
\hline Gross Alpha* & $15 \mathrm{E}-06$ & -- & - & -- \\
\hline Gross Beta ${ }^{\ddagger}$ & $3 \mathrm{E}-05$ & -- & - & -- \\
\hline Uranium $^{\S}$, total & $6 \mathrm{E}-04$ & -- & $6 \mathrm{E}-6$ & -- \\
\hline \multicolumn{5}{|c|}{$\begin{array}{l}\text { Note: } \mu \mathrm{Ci} / \mathrm{L}=\text { microcuries per liter; } \mu \mathrm{Ci} / \mathrm{m}^{3}=\text { microcuries per cubic meter. } \\
\text { "DOE Order } 5400.5 \text {, Chapter III (DOE } 1990) \text {. } \\
\text { 'DCG for tritium in air }\left(2 \times 10^{-1}\right) \text { is adjusted for skin absorption. } \\
\text { "EPA-570/9-76-003 (EPA 1976). } \\
\text { "A conversion from picocuries per liter }(\mathrm{pCi} / \mathrm{L}) \text { to micrograms per liter }(\mu \mathrm{g} / \mathrm{L}) \text { may be } \\
\text { made using } 1.3 \times 10^{-6} \text { picocuries per microgram }(\mathrm{pCi} / \mu \mathrm{g}) \text { for uranium as it exists in } \\
\text { drinking } \\
\text { water ( } 40 \mathrm{CFR} 141) \text {. }\end{array}$} \\
\hline
\end{tabular}


Table G-2. Radiation Standards for Protection of the Public in the Vicinity of U.S. Department of Energy Facilities

General Dose Limits

All Pathways*

The effective dose equivalent for any member of the public from all routine DOE operations ${ }^{\dagger}$ (natural background and medical exposures excluded) shall not exceed the values given below:

Effective Dose Equivalent $^{\ddagger}$

$\underline{\mathrm{mrem} / \mathrm{yr}} \underline{(\mathrm{mSv} / \mathrm{yr})}$

Primary limit

100

(1)

$\underline{\text { Air Pathway }}^{* *}$

Maximum offsite residence
Effective Dose Equivalent

$\underline{\operatorname{mrem} / \mathrm{yr}} \quad \underline{(\mathrm{mSv} / \mathrm{yr})}$

10

$(0.10)$

"DOE Order 5400.5, Chapters I and II (DOE 1990).

'Routine DOE operations means normal planned activities, including remedial actions and naturally occurring radionuclides released by DOE processes and operations.

${ }^{\ddagger}$ Effective dose equivalent (EDE) will be expressed in roentgen equivalent man (rem) (or millirem) with the corresponding value in sievert (or millisievert) in parentheses.

*40 CFR 61, Subpart H for radionuclides, National Emission Standard for Hazardous Air Pollutants (NESHAP). 
Table G-3. Groundwater Monitoring Parameters Required by 40 CFR 265, Subpart F*

Contamination
Indicator

$\mathrm{pH}$

Specific Conductivity

Total Organic Halogen (TOX)

Total Organic Carbon (TOC)
Groundwater

Quality

Chloride

Iron

Manganese

Phenol

Sodium

Sulfate
Appendix III $^{\dagger}$

Drinking Water Supply

Arsenic

Barium

Cadmium

Chromium

Fluoride

Lead

Mercury

Nitrate (as N)

Selenium

Silver

Endrin

Lindane

Methoxychlor

Toxaphene

2,4-D

2,4,5-TP Silvex

Radium

Gross Alpha

Gross Beta

Coliform Bacteria

Turbidity

"Resource Conservation and Recovery Act (40 CFR 265).

${ }^{\dagger} 40$ CFR 265, Appendix III. 
Table G-4. U.S. Environmental Protection Agency Interim Primary Drinking-Water Supply Parameters

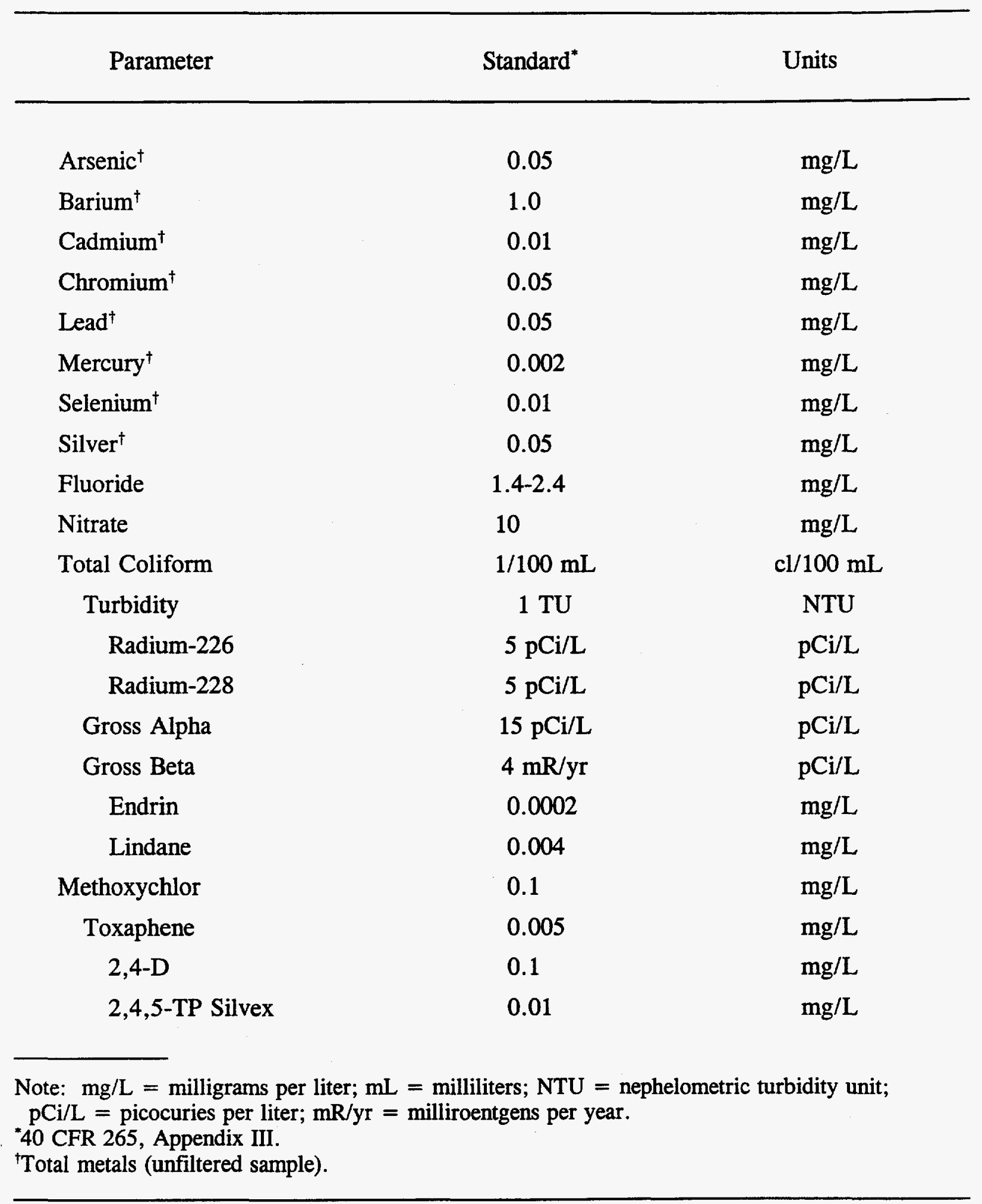




\section{REFERENCES}

DOE 1988: U.S. Department of Energy, "General Environmental Protection Program," DOE Order 5400.1, DOE, Washington, DC (1988; change 1, June 21, 1990).

DOE 1990: U.S. Department of Energy, Chapter I, "General Radiological Protection of the Public and the Environment;" Chapter II, "Requirements for Radiation Protection of the Public and the Environment;" and Chapter III, "Derived Concentration Guides for Air and Water," DOE Order 5400.5, DOE, Washington, DC (February 1990).

EPA 1976: U.S. Environmental Protection Agency, "USEPA National Interim Primary Drinking Water Regulations," EPA-570/9-76-003, EPA, Washington, DC (1976).

Resource Conservation and Recovery Act (RCRA) of 1976. Public Law 94-580, 1976, 90 Statute 2795.

10 CFR 1021, 1992. "National Environmental Policy Act Implementing Procedures," as revised April 24, 1992.

40 CFR 61, Subpart $\mathrm{H}$ for radionuclides. National Emission Standards for Hazardous Air Pollutants (NESHAP).

40 CFR 141, 1975. "National Primary Drinking Water Regulations," as amended January 15, 1992.

40 CFR 265, 1980. "Interim Status Standards for Owners and Operators of Hazardous Waste Treatment, Storage, and Disposal Facilities," as amended December 23, 1991. 


\section{APPENDIX H}

1994 ENVIRONMENTAL COMPLIANCE ACTIVITIES

AT THE KAUAI TEST FACILITY 
H-2 


\section{CONTENTS}

Page

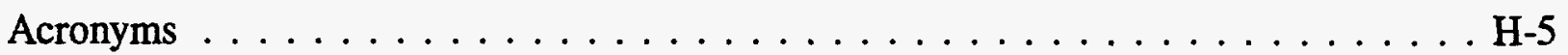

H.1 Introduction $\ldots \ldots \ldots \ldots \ldots \ldots \ldots \ldots \ldots \ldots \ldots \ldots \ldots \ldots$ H-7

H.1.1 Facilities and Operations $\ldots \ldots \ldots \ldots \ldots \ldots \ldots$ H-7

H.1.2 Geology and Hydrology $\ldots \ldots \ldots \ldots \ldots \ldots \ldots \ldots$ H-7

H.1.3 Biology and Population . . . . . . . . . . . . . . H-9

H.1.4 Meteorology . . . . . . . . . . . . . . . . . H-10

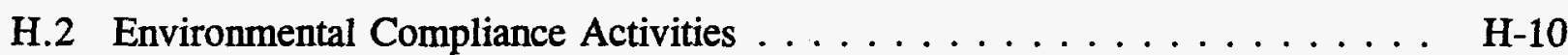

H.2.1 National Environmental Policy Act Compliance . . . . . . . . H H-10

H.2.2 Environmental Permits . . . . . . . . . . . . . . . H-11

H.2.3 1994 Release Reporting . . . . . . . . . . . . . . . . . H-12

H.2.4 Environmental Restoration Project Activities . . . . . . . . . H-12

H.2.5 Environmental Surveillance . . . . . . . . . . . . H-13

H.3 Environmental Monitoring and Mitigation Action Plan $\ldots \ldots \ldots$ H-18

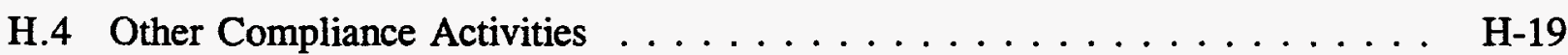

H.4.1 Spill Prevention Control and Countermeasure Plan . . . . . . . . . H-19

H.4.2 Toxic Substances Control Act . . . . . . . . . . . . . . . . H-19

\section{FIGURES}

H-1 Map of the Pacific Missile Range Facility and the

Adjacent Area . . . . . . . . . . . . . . . . . . . H-8

H-2 Soil Sampling Locations at the Main Compound and

Around the Kauai Test Facility $\ldots \ldots \ldots \ldots \ldots \ldots \ldots$ H-14

H-3 Sampling Locations at the Kokole Point Launch Complex $\ldots \ldots \ldots \ldots \ldots$ H-15

H-4 Off-Site Soil Sampling Locations $\ldots \ldots \ldots \ldots \ldots \ldots \ldots \ldots$ H-16

\section{TABLES}

H-1 Summary of 1994 Reportable Quantity Accidental Release Reporting . . . . . H-12

H-2 Individual Radiological Results for Soil Sampling at KTF in $1994 \ldots \ldots$ H-20

H-3 Individual Nonradiological Results for Soil Sampling at KTF in $1994 \ldots \ldots \ldots \ldots \ldots \ldots \ldots$. . . . . . . . . . . . . . . . . . H

H-4 Results of Replicate Sampling . . . . . . . . . . . . . . . H-26

H-5 Summary of Radiological Data for Soil Samples Collected in 1994 . . . . . . . H-29

H-6 Summary of Nonradiological Data for Soil Samples Collected at KTF in 1994

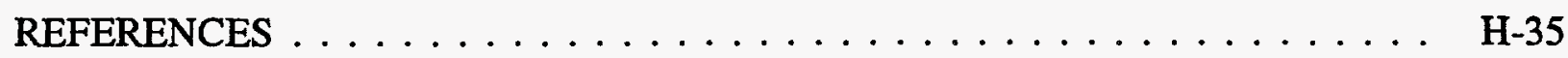


H-4 


\section{ACRONYMS}

$\begin{array}{ll}\text { Al } & \text { aluminum } \\ \text { Ba } & \text { barium } \\ \text { Be } & \text { beryllium } \\ \text { CERCLA } & \text { Comprehensive Environmental Response Compensation and Liability Act } \\ \text { cm/yr } & \text { centimeters per year } \\ \text { Co } & \text { cobalt } \\ \text { Cr } & \text { chromium } \\ \text { Cs-137 } & \text { cesium-137 } \\ \text { Cu } & \text { copper } \\ \text { DOD } & \text { U.S. Department of Defense } \\ \text { DOE } & \text { U.S. Department of Energy } \\ \text { DRMO } & \text { Defense Revitalization Marketing Office } \\ \text { EA } & \text { environmental assessment } \\ \text { EORC } & \text { Environmental Operations Record Center } \\ \text { EPA } & \text { U.S. Environmental Protection Agency } \\ \text { ER } & \text { Environmental Restoration } \\ \text { ES\&H } & \text { environment, safety, and health } \\ \text { Fe } & \text { iron } \\ \text { FONSI } & \text { finding of no significant impact } \\ \text { ft } & \text { feet } \\ \text { gal. } & \text { gallon } \\ \text { gpm } & \text { gallons per minute } \\ \text { HE } & \text { high explosives } \\ \text { hr } & \text { hour } \\ \text { ICP } & \text { inductively coupled plasma (method) } \\ \text { in./yr } & \text { inches per year } \\ \text { km } & \text { kilometers } \\ \text { KTF } & \text { Kauai Test Facility } \\ \text { m } & \text { meters } \\ \text { Mg } & \text { magnesium } \\ \text { mg/L } & \text { milligrams per liter } \\ \text { mi } & \text { miles } \\ \text { NESHAP } & \text { National Emission Standards for Hazardous Air Pollutants } \\ \text { Ni } & \text { nickel } \\ \text { NRC } & \text { National Response Center } \\ \text { NSPS } & \text { New Source Performance Standards } \\ \text { PA } & \text { Preliminary Assessment } \\ \text { Pb } & \text { lead } \\ \text { PBV } & \text { post-boost vehicle } \\ \text { PCB } & \text { polychlorinated biphenyl } \\ \text { PMRF } & \text { Pacific Missile Range Facility } \\ \text { PTO } & \text { permit-to-operate } \\ \text { RQ } & \text { reportable quantity } \\ & \end{array}$


SARA Superfund Amendments and Reauthorization Act

SDI Strategic Defense Initiative

SEA site evaluation accomplished

SI site inspection

SNL Sandia National Laboratories

SOP standard operating procedure

SPCC Spill Prevention Control and Countermeasure

Sr strontium

STARS Strategic Targeting System

SVOC semi-volatile organic compound

TAL target analyte list

TPH total petroleum hydrocarbons

TSCA Toxic Substances Control Act

USASSDC U.S. Army Space and Strategic Defense Command

UST underground storage tank

VOC volatile organic compound

$\mathrm{Zn} \quad$ zinc 


\section{H.1 INTRODUCTION}

Sandia National Laboratories (SNL) operates a rocket preparation and launch facility called the Kauai Test Facility (KTF) at the U.S. Navy's Pacific Missile Range Facility (PMRF), Barking Sands, for the U.S. Department of Energy (DOE). PMRF is located on the west side of the island of Kauai, Hawaii (Figure H-1). KTF is used to launch rockets in support of DOE missions, as well as other U.S. government projects (DOE 1992).

\section{H.1.1 Facilities and Operations}

SNL's KTF is located on the north part of PMRF near Nohili Point. The first facilities at KTF were constructed in the early 1960s to support the National Readiness Program. The most recent construction, completed in 1994, added four buildings to support DOE and Strategic Defense Initiative (SDI) launches.

KTF is used for testing rocket systems with scientific and technological payloads, advanced development of maneuvering reentry vehicles, scientific studies of atmospheric and exoatmospheric phenomena, and SDI programs. Nuclear devices have never been launched from KTF.

The KTF launcher field was originally designed to accommodate 40 launch pads, but only 15 were constructed. Of these, 11 have had their launchers removed. Beyond the implementation of portions of the original plan, two additional launch pads have been constructed: Pad 41 at Kokole Point, and Pad 42, the Strategic Targeting System (STARS) launch pad. The launcher field site has a number of permanent facilities used to support rocket operations and is configured to meet programmatic needs.

The administrative area of KTF, known as the Main Compound, is located in a fenced area near the North Nohili access road from PMRF. Within the fenced compound, a number of trailers and vans are interconnected with a network of concrete docks and covered walkways. The majority of these temporary facilities are used during operational periods to support field staff at KTF. In nonoperational periods, maintenance continues and dehumidifiers remain in operation. In addition, there are a number of permanent buildings, most of which are in use year-round to support and maintain KTF facilities (Helgesen 1990).

\section{H.1.2 Geology and Hydrology}

KTF and PMRF are located on the seaward margin of the broad Mana Coastal Plain of Kauai. This plain is composed of alluvium washed from uplands, calcareous and clayey lagoon deposits, sand dunes, and beach rock. The poorly consolidated deposits of the present plain were formed in a shallow lagoon behind an ancient beach ridge. Most of a large wetland was filled in and planted with sugar cane by 1936, leaving only some small areas of wetland near Mana, about 10,000 feet (ft) from KTF. 


\section{$P$ acific Oce a $n$}

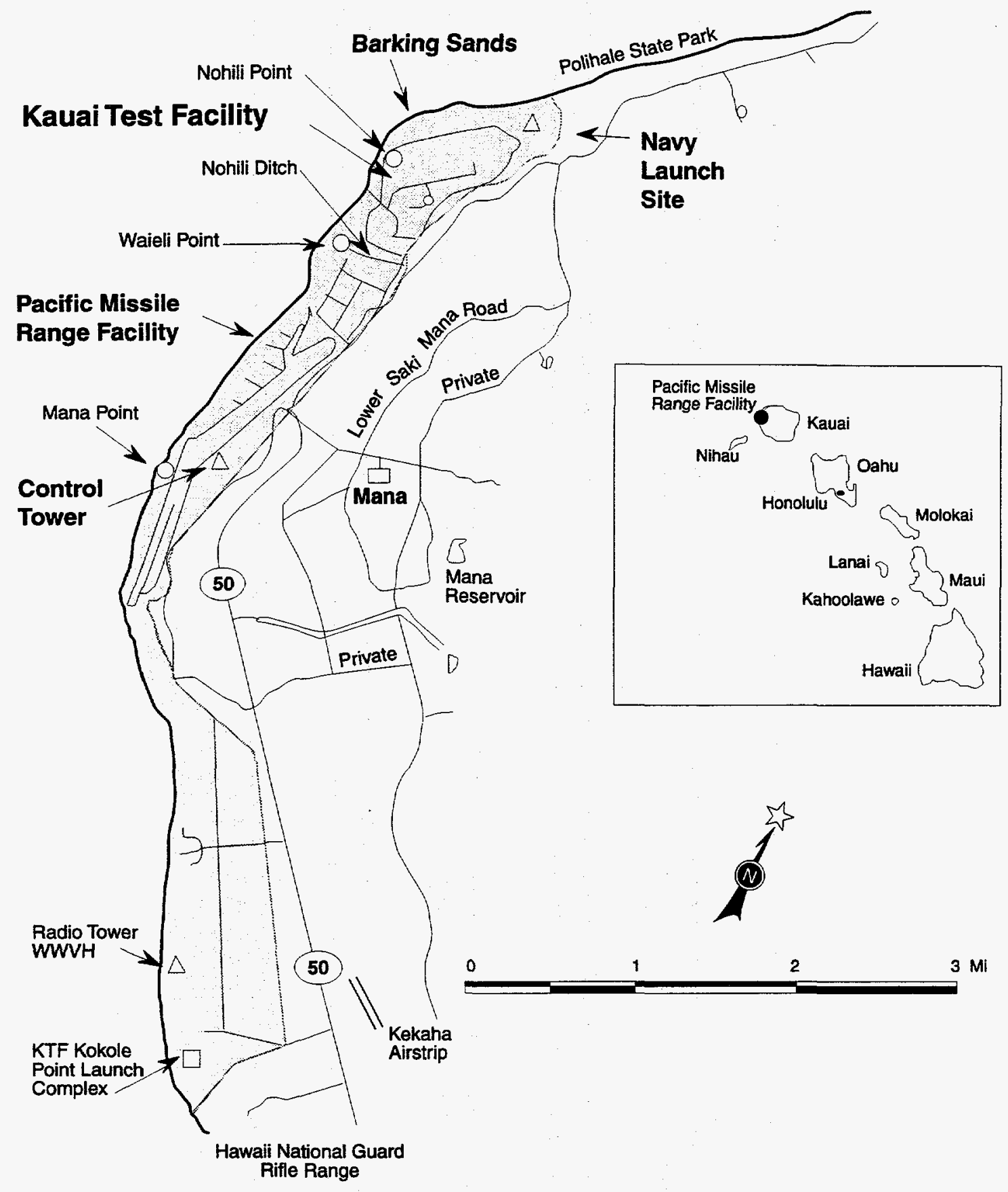

Figure H-1. Map of the Pacific Missile Range Facility (PMRF) and the Adjacent Area. The Kauai Test Facility (KTF) is to the north, near Nohili Point. 
KTF lies in the rain shadow of Mounts Kawaikini and Waialeale. Annual rainfall is approximately 20 inches per year (in./yr). There is no integrated surface drainage on the site. The sand is so permeable and its moisture-holding capacity so low that no drainage pattern has become established on the surface. Rain usually sinks into the sand and disappears, though during hard rains surface runoff is visible after the soil becomes saturated.

The Mana Coastal Plain is composed of a wedge of terrestrial and marine sediments overlying a volcanic basement. The basement rock forms an outcrop at the inland edge of the plain; its steep slope is a cliff formed during a former high-stand of the sea. The volcanic basement plunges below the plain at a dip of approximately 5 degrees and continues to the coast, where it is approximately $400 \mathrm{ft}$ deep.

The seaward edge of the plain is covered by fossil sand dunes formed when the sea level was lower than it is now. PMRF is located almost entirely on these dunes, which are now no higher than approximately $10 \mathrm{ft}$, except to the north of KTF, where they are $\leq 100 \mathrm{ft}$ high.

The three geological formations (bedrock, alluvium, and dunes) constitute hydraulically connected aquifers. The basement volcanics are highly permeable, containing brackish water floating on seawater. The overlying sediments act as a cap rock because of their low permeability; but although they are saturated, they are not exploitable as an aquifer because of their unfavorable hydraulic characteristics.

The dune sand aquifer, on which PMRF lies, has moderate hydraulic conductivity and reasonable porosity. It consists of a lens of brackish groundwater floating on seawater and is recharged by storm rainfall and seepage from the underlying sediments. The only record of an attempt to exploit this groundwater is of a well drilled for the Navy in 1974, 4 to 5 miles (mi) south of KTF. Drilled to a depth of $42 \mathrm{ft}$, the well encountered only fine sand and coral gravel, but when it was tested at 300 gallons per minute (gpm), it contained 2800 milligrams per liter $(\mathrm{mg} / \mathrm{L})$ chloride, which is too brackish for plants. This well is not being used (SNL 1986).

\section{H.1.3 Biology and Population}

The principal vegetation found on Kauai consists of two introduced shrub species: kiawe, a mesquite, and koahaole, a wild tamarind. Portions of the island are covered with nearly impenetrable thickets of kiawe and koahaole (DOE 1992). The land on which the present KTF facilities lie has been cleared of brush and has a thin cover of grasses and herbs. The sandy soil is barren and appears incapable of supporting agriculture unless it is improved by being mixed with organically rich soil, fertilized extensively, and irrigated.

No mammals or signs of mammals were encountered during a 1986 field survey (SNL 1986). However, it is likely that there may be populations of mice and rats. The endangered Hawaiian hoary bat (Lasiurus cinereus semotus) may also be occasionally found since there are breeding populations elsewhere on Kauai. 
Twenty-two species of birds are found on the range, as well as three more just outside the range (SNL 1986). These include five species native to Hawaii. There are also several species of waterfowl present during some portion of the year, although they were not seen during the 1986 survey.

The closest population center, Kekaha (population 3300), is $8 \mathrm{mi}$ from KTF. KTF employs 14 permanent on-site personnel; two are employed by SNL and the rest are SNL contractors. During operational periods when rocket launches occur, an additional 50 to 130 persons from the United States mainland are employed at KTF (DOE 1992).

\section{H.1.4 Meteorology}

Lying in the rain shadow of Mounts Kawaikini and Waialeale, KTF is sheltered from the predominant northeast tradewinds and is one of the driest sections of Kauai. Average annual rainfall at KTF is just over 20 in. and occurs mostly between October and April. Under normal conditions, winds are generally light and variable; abnormal conditions can result in gusty winds in excess of 30 knots from the south, west, or north. The mean monthly temperature is $70^{\circ} \mathrm{F}$, with maximums in the low $90 \mathrm{~s}$ and minimums in the mid-50s.

\section{H.2 ENVIRONMENTAL COMPLIANCE ACTIVITIES}

\section{H.2.1 National Environmental Policy Act Compliance}

For KTF, development of a comprehensive site-wide Environmental Assessment (EA), Kauai Test Facility Environmental Assessment, was completed in 1992 (DOE 1992). A finding of no significant impact (FONSI) was issued on July 17, 1992.

In completing this EA, several environmental surveys were carried out. Reports included the following:

- A Green Sea Turtle Survey Report - This survey found at least 32 green sea turtles (Chelonia mydas agassizi) at up to five locations at KTF. The study concluded that constructing an additional launch pad and conducting further launches similar to those conducted at KTF since 1962 probably will not have any quantifiable effects on green sea turtles residing in waters near KTF (IT 1990a).

- A Botanical Survey Report - This survey identified four major vegetation types at KTF and recommended that vehicles be kept off the beach and dunes. The report recommended moving the entire Ophioglossum concinnum colony (a Category 1 proposed endangered fern) to a compatible area within PMRF because of the colony's proximity to a beach access road and its location in a frequently-mowed kiawe/koahaole vegetation zone (IT 1990b).

- An Ornithological Survey Report - This survey determined relative densities of bird species and identified mammalian species at KTF (IT 1990c). 
- A Soil Sampling Report - This sampling was undertaken to delineate the extent and concentration of lead $(\mathrm{Pb})$, aluminum ( $\mathrm{Al})$, and beryllium $(\mathrm{Be})$ in the soil at $\mathrm{KTF}$ and to determine whether the concentrations threaten human health or the environment. The soil sampling results were used to estimate the potential for future soil contamination or human exposure from use of KTF as a launch facility (IT 1990d).

- Archaeological Survey and Sampling - This survey found no significant cultural resources on the surface at KTF, but subsurface testing within one area indicated a potential for subsurface cultural resource materials (Gonzalez and Berryman 1990).

One rocket (STARS M-2) was launched from KTF in 1994. The launch was covered by the KTF site-wide EA, published in July 1992 (DOE 1992), and the DOD STARS Environmental Impact Statement (EIS) published in February 1992 (DOD 1992). The STARS EIS is incorporated by reference into the KTF site-wide EA. STARS M-2 (Operation and Deployment Simulator) was launched on July 22, 1994. The missile was similar to the previous STARS missions but also contained a Post-Boost Vehicle (PBV). The mission demonstrated the missile's flight worthiness and its ability to operate the PBV. The STARS M-2 payload consisted of ten deployable test objects. These objects were successfully delivered on a ballistic trajectory from Hawaii to the broad ocean area near the Kwajalein Atoll. The mission was a success; all on-board systems functioned normally and all sensors acquired valid data. The information gathered will be applied to the development of a ballistic missile defense system.

\section{H.2.2 Environmental Permits}

Air - There are no New Source Performance Standards (NSPS), Prevention of Significant Deterioration (PSD), or National Emission Standards for Hazardous Air Pollutants (NESHAP) sources for the facility, and no air permits are held either by DOE for KTF or by the U.S. Department of Defense (DOD) for PMRF. However, the two electrical generators at KTF are permitted by the State of Hawaii under Permit-to-Operate (PTO) No. P-737-1591.

Water - Sanitary waste is treated on-site by a waste-water treatment system consisting of three septic tanks and one leach pit into brackish water. The limited quantities of sewage released from KTF do not impact any protected water. Periodic drainage of septic tanks is accomplished by State of Hawaii licensed contractors who dispose of wastes according to state procedures. The facility currently has three septic tanks on-site. The State of Hawaii does not require permits for septic tanks.

Solid Waste - In 1994, KTF became a "small quantity hazardous waste generator" under EPA Permit Number HI0000363309. All hazardous waste is disposed of through the Defense Revitalization Marketing Office (DRMO) in Honolulu. 


\section{H.2.3 1994 Release Reporting}

Reportable Quantity (RQ) information is required by the Comprehensive Environmental Response Compensation and Liability Act (CERCLA) and Superfund Amendments and Reauthorization Act (SARA), Title III. CERCLA requires that any release to the environment in any 24-hour (hr) period of any pollutant or hazardous substance in a quantity greater than or equal to the RQ be reported immediately to the National Response Center (NRC). However, if the release is "federally permitted" under CERCLA Section 101(10)(H), it is exempted from CERCLA reporting. This reporting exemption also applies to any federally permitted release under SARA, Title III.

There was one RQ release for KTF in 1994 (Table H-1). The release was planned as part of the mission for the STARS M-2 launch. A sounding rocket was launched by SNL/Hawaii (SNL/HI) from KTF. A small quantity of lead was included as an integral part of the explosive components utilized in the vehicle. The lead was released to the atmosphere by the application of linear shape charges in routine case cutting events.

Table H-1. Summary of 1994 Reportable Quantity Accidental Release Reporting

\begin{tabular}{llcccccc}
\hline $\begin{array}{l}\text { Event } \\
\text { Date }\end{array}$ & $\begin{array}{l}\text { SNL/HI } \\
\text { Location }\end{array}$ & $\begin{array}{c}\text { Hazardous } \\
\text { Material }\end{array}$ & $\begin{array}{c}\text { Quantity } \\
\text { (lb) }\end{array}$ & $\begin{array}{c}\text { RQ } \\
\text { (lb) }\end{array}$ & $\begin{array}{c}\text { Released } \\
\text { to }\end{array}$ & $\begin{array}{c}\text { NRC } \\
\text { No. }\end{array}$ & $\begin{array}{c}\text { Report } \\
\text { Date }\end{array}$ \\
\hline $07 / 22 / 94$ & KTF & Lead & 1.49 & 1 & Atmosphere & 251166 & $07 / 28 / 94$ \\
\hline
\end{tabular}

\section{H.2.4 Environmental Restoration Project Activities}

In January 1994, the SNL Enviromental Restoration (ER) Project submitted to the U.S. Environmental Protection Agency (EPA), Region IX, a CERCLA Preliminary Assessment (PA) report for KTF. A subsequent and more extensive Site Inspection (SI) field investigation was conducted at KTF during March and April 1994. The SI field investigation primarily involved the collection of samples at three potential chemical-release sites: the Photographic Laboratory Discharge Site and the Drum Rack Area within the Main Compound, and the adjacent Rocket Launcher Field. Samples of soil, soil vapor, groundwater, and storm water were collected to characterize these three potential release sites and various other locations around the Main Compound. Additionally, sediment and surface-water sampling was conducted along the offsite drainage ditch network. A total of 191 samples was collected. Analyses revealed that no significant amounts and/or concentrations of organic (volatile organic compounds [VOCs], semi-volatile organic compounds [SVOCs], total petroleum hydrocarbons [TPH], high explosives [HE], and herbicides) or inorganic (target analyte list [TAL] metals) compounds were present in soil at levels warranting remediation. No additional assessment or sampling 
is necessary for the KTF site. The SI report was submitted to EPA in May 1995 and recommends that the EPA apply a "site evaluation accomplished" (SEA) designation to KTF.

\section{H.2.5 Environmental Surveillance}

1994 Limited Soil Sampling - In July 1994, staff with the SNL Air Quality Department Environmental Surveillance Program collected a limited number of soil samples at KTF. The program objectives are to detect any potential releases and/or migration of contaminated material related to on-site operations to off-site locations, and to determine potential impacts (if any) of site-related activities to the off-site population and the surrounding environment.

The specific objective of the 1994 sampling was to provide limited baseline data for the radiological and nonradiological metal concentrations in the soil at KTF and in the soil around KTF. Due to limited resources, the sampling locations, the number of samples, and analyses performed were prioritized based on the following: (1) sampling areas where, if present, contamination would be expected to exist; (2) sampling areas where, if present, contamination would pose the greatest potential for impacts to workers and the environment; and (3) an analysis strategy that would provide a wide range of information.

Soil samples were collected off-site and on-site. Off-site sampling provided data that represent areas unaffected or unrelated to site activities. Results for samples collected from on-site locations were compared to the off-site data to assess the potential impact (if any) of site activities. All on-site samples were taken from locations of unrestricted access at KTF.

Sample Collection and Analysis - Soil samples were gathered in accordance with the activityspecific environment, safety, and health (ES\&H) Standard Operating Procedure (SOP) entitled Environmental Sampling Procedure (SNL 1992). All samples were analyzed for inductively coupled plasma (ICP) standard 20 stable metals, gross alpha, and gross beta, and by gamma spectroscopy. Only the gamma spectroscopy results for cesium-137 (Cs-137) are reported herein. The list of radionuclide results reported by gamma spectroscopy is lengthy. All results were reviewed; the complete list of gamma spectroscopy results are on file in the Environmental Operations Record Center (EORC) at SNL/New Mexico (SNL/NM).

Thirty-two samples were collected (including replicate samples) from KTF: 5 from around the Main Compound, 16 from "miscellaneous" locations on-site, and 11 samples from off-site. The five soil samples collected at the KTF Main Compound were taken from five locations along the security fence around the compound (Figure H-2). For the 16 miscellaneous samples, 14 soil sampling locations were selected from various areas at KTF (Figure H-2), including the Kokole Point Launch Complex (Figure H-3). Nine off-site soil sampling locations were selected (Figure H-4). Much of the area around the Barking Sands Missile Range is agricultural; the soil material of the agricultural areas differs from the sandy material of KTF. Off-site sampling locations only include areas with soil material similar to that found at KTF. 


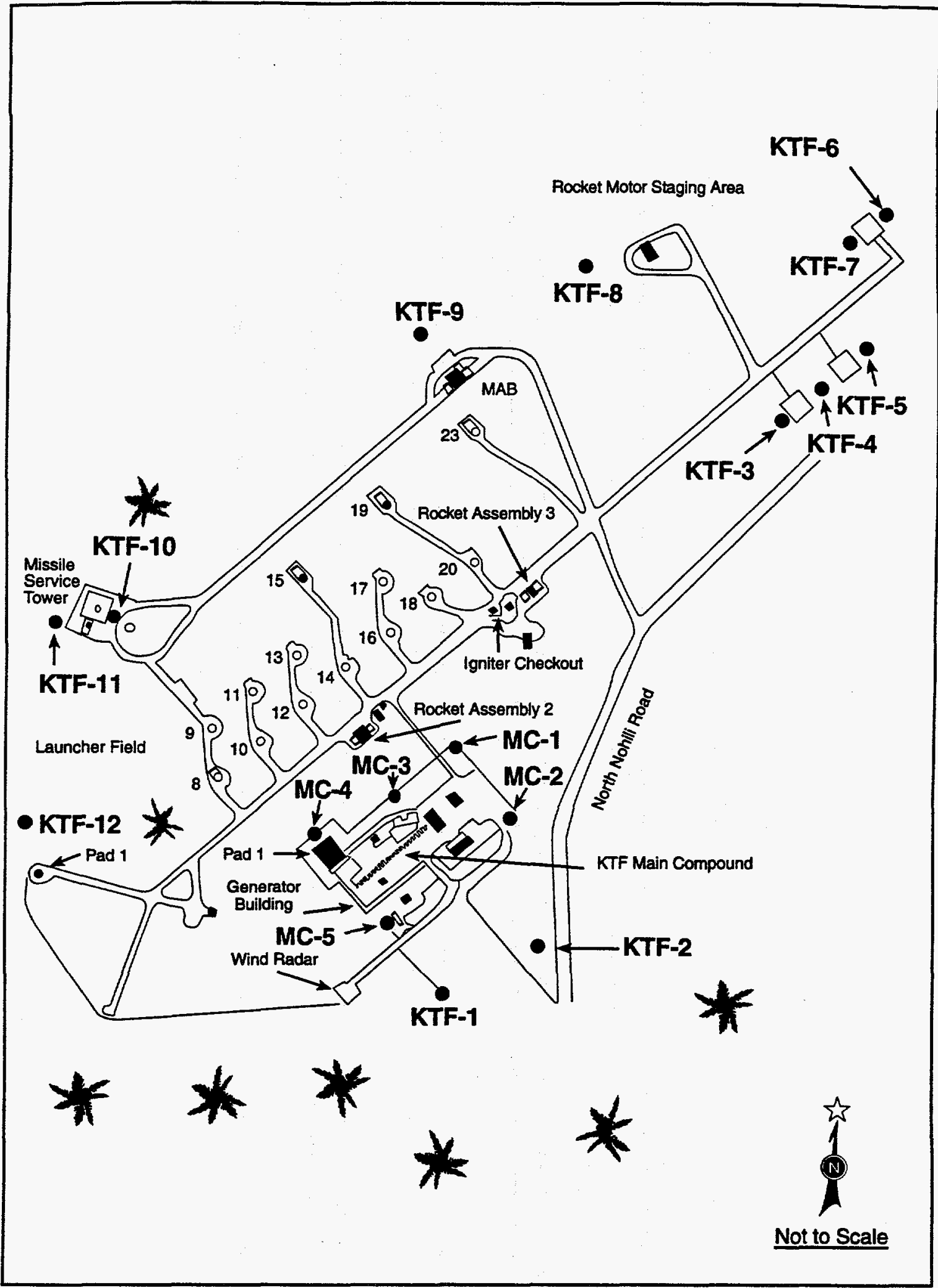

Figure H-2. Soil Sampling Locations at the Main Compound and Around the Kauai Test Facility 


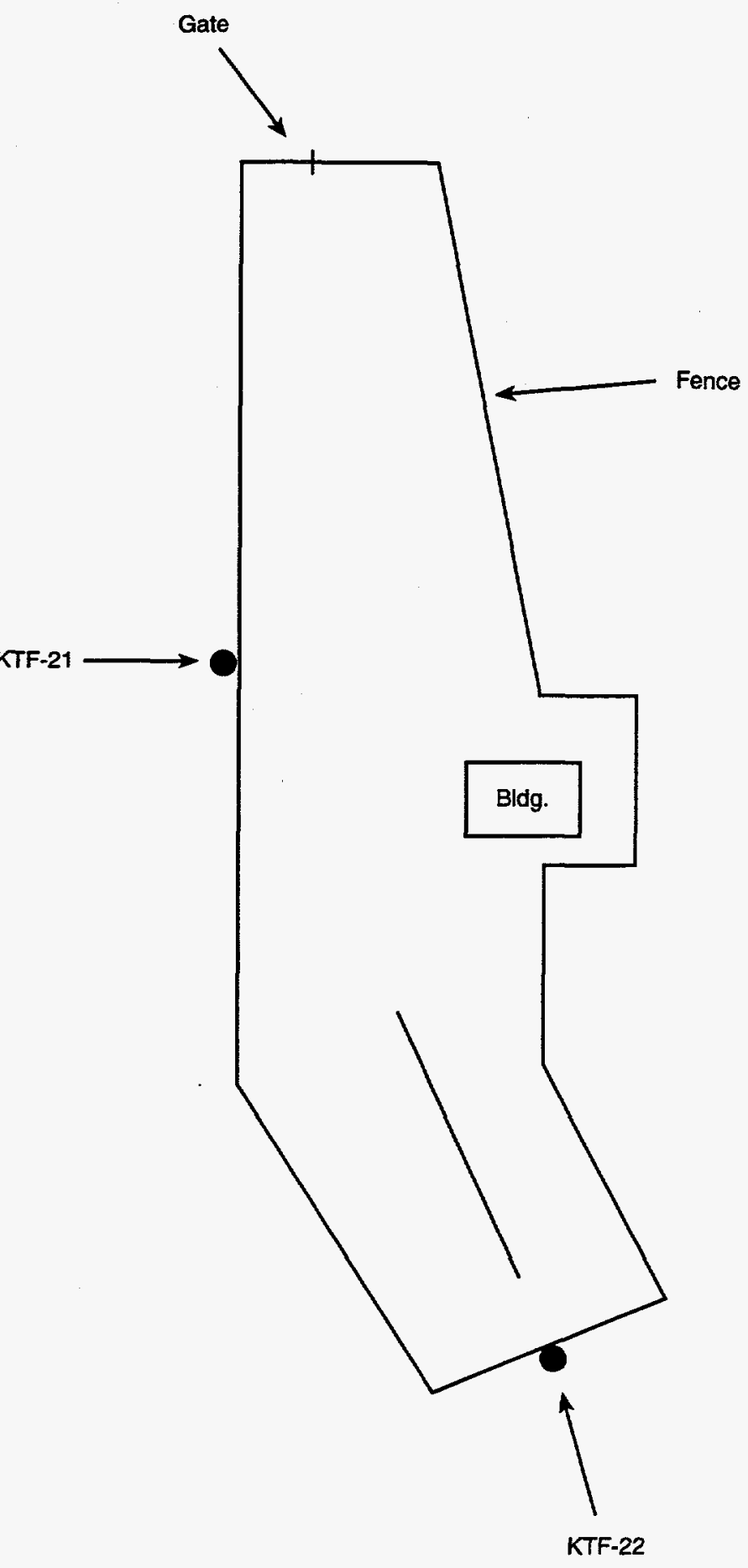

Figure H-3. Sampling Locations at the Kokole Point Launch Complex 


\section{Pacific Ocean}

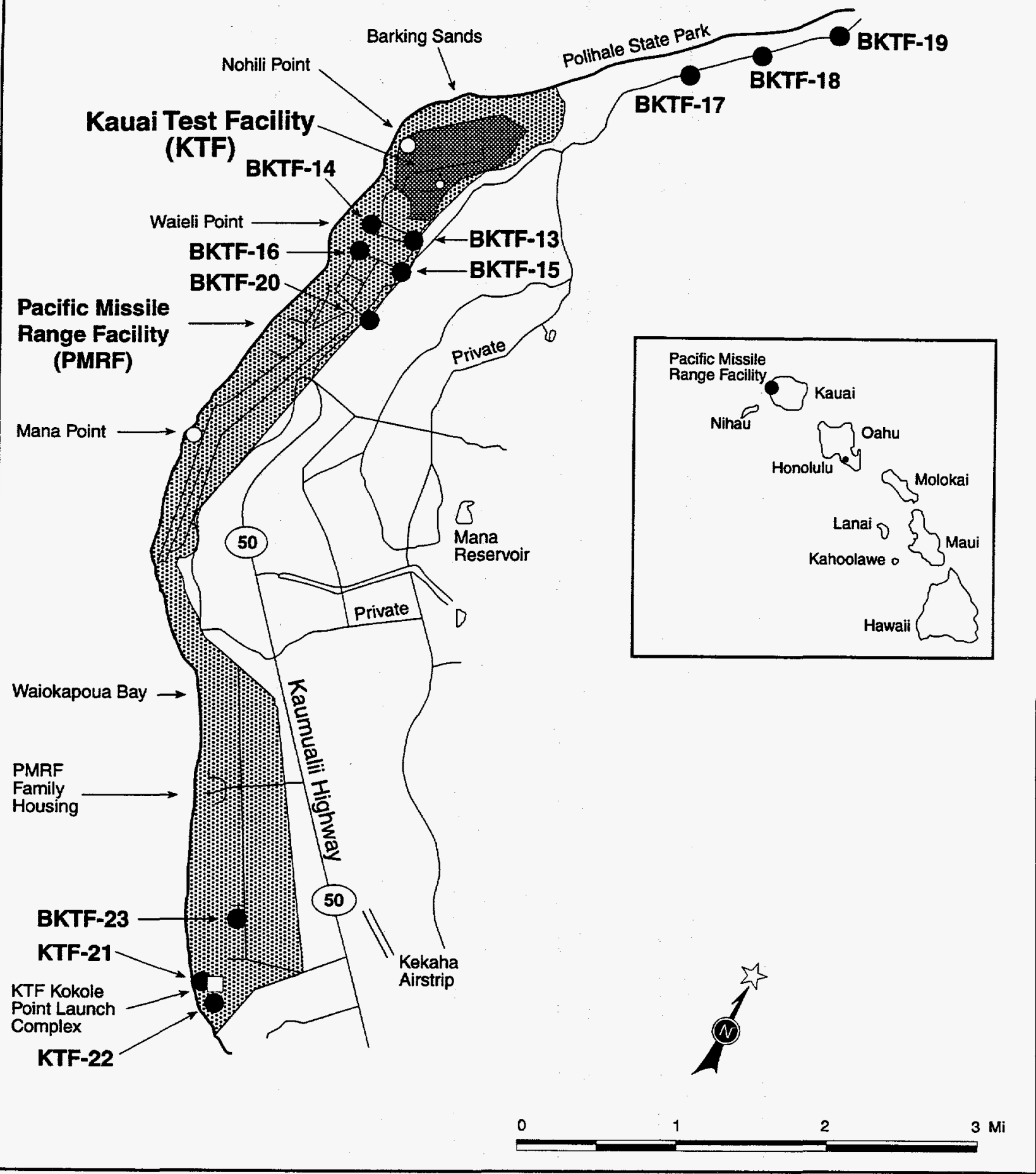

Figure H-4. Off-Site Soil Sampling Locations 
Results - Figures H-2, H-3, and H-4 show the soil sampling locations. Tables H-2 and H-3 report individual sample data. Less-than-detection values were set equal to the detection value for statistical calculations. In cases of replicate sampling, only the first sample collected (sample A) was used in summary calculations to avoid skewing summary data toward replicate sample data. Table H-4 summarizes the replicate sampling results.

For samples collected on-site, radiological and nonradiological results were compared to the upper 95 percent (mean plus two standard deviations) confidence limit and range of values of those samples collected off-site. Individual sample values greater than the upper 95 percent confidence interval and greater than the range of observed values were considered as potentially contaminated.

Historical information and process knowledge about the activities at KTF do not indicate the use or dispersal of radioactive material. Soil samples were collected from 19 on-site locations for radiological analysis. Table $\mathrm{H}-2$ includes all data from the radionuclide analysis of the soil samples; Table H-5 summarizes the results. Radiological results for samples collected from on-site locations were indistinguishable from the results for samples collected off-site. Soil sampling appears to confirm the lack of radionuclide contamination.

Table H-6 summarizes the nonradiological soil data. Considerable variation in off-site sample data was initially observed. A standard outlier test was performed on the off-site data set. Table H-3 includes all data; Table H-6 presents the summary statistics that exclude the statistical outliers. Future sampling should include further defining of the off-site concentrations of the metals of interest.

Five locations around the Main Compound were sampled: $\mathrm{MC}-1$ contained elevated zinc $(\mathrm{Zn})$ concentrations; MC-2 contained elevated barium $(\mathrm{Ba}), \mathrm{Pb}$, and $\mathrm{Zn}$ concentrations; MC-3 contained elevated strontium ( $\mathrm{Sr}$ ) and $\mathrm{Zn}$ concentrations; $\mathrm{MC}-4$ contained elevated $\mathrm{Zn}$ concentrations; and MC-5 contained elevated Sr concentrations.

Fourteen locations around KTF were sampled: KTF-1, KTF-10, KTF-21, and KTF-22 contained elevated $\mathrm{Zn}$ concentrations; KTF-2 contained elevated $\mathrm{Ba}$, chromium $(\mathrm{Cr})$, cobalt $(\mathrm{Co})$, iron $(\mathrm{Fe}), \mathrm{Pb}$, magnesium $(\mathrm{Mg})$, nickel $(\mathrm{Ni})$, and $\mathrm{Zn}$ concentrations; KTF-3 contained elevated $\mathrm{Cr}, \mathrm{Co}, \mathrm{Fe}, \mathrm{Mg}, \mathrm{Ni}$, and silica concentrations; KTF-4 contained elevated $\mathrm{Fe}$ and $\mathrm{Ni}$ concentrations; KTF- 5 contained elevated copper $(\mathrm{Cu}), \mathrm{Ni}$, and silica concentrations; KTF-8 and KTF-9 both contained elevated silica concentrations; and KTF-12 contained elevated $\mathrm{Cu}$ concentrations.

A total of 19 locations were sampled on-site. Eleven separate metals were elevated above offsite concentrations for at least one sampled location on-site. Zinc was elevated above off-site concentrations at nine locations, $\mathrm{Ni}$ at four, silica at four, $\mathrm{Fe}$ at three, $\mathrm{Ba}$ at two, $\mathrm{Pb}$ at two, $\mathrm{Cu}$ at two, $\mathrm{Mg}$ at two, $\mathrm{Cr}$ at two, $\mathrm{Co}$ at two, and $\mathrm{Sr}$ at two. 
Many of the elevated metals concentrations are only marginally above off-site concentrations, and only in a few locations. Due to the relatively small number (nine) of off-site sample locations and considering the natural variation in metals concentrations, this is not by itself surprising. What is of concern is the magnitude of the elevated concentrations and the frequency of occurrence in some cases. For example, $\mathrm{Zn}$ and $\mathrm{Ni}$ are elevated in many on-site locations. Many of these sample results show considerably greater concentrations than the offsite results. Results for $\mathrm{Zn}$ show elevated concentrations at seven locations at the KTF facility. $\mathrm{Zn}$ is also elevated at the two sampled locations at the Kokole Point Launch Complex, which is located a considerable distance from the main KTF facility. Several off-site sample locations exist between these two sampled areas; these samples do not exhibit $\mathrm{Zn}$ concentrations elevated to the magnitude of these on-site locations. Further analysis of the data is required.

\section{H.3 ENVIRONMENTAL MONITORING AND MITIGATION ACTION PLAN}

Pursuant to DOE Order 5400.1, General Environmental Protection Program (DOE 1988), a Kauai Test Facility Environmental Monitoring Plan (EMP) was published in 1992 (IT 1992). This EMP provides a description of planned and ongoing environmental activities at KTF and demonstrates compliance with regulatory requirements imposed by applicable federal, state, and local agencies. The EMP also supports DOE environmental management decisions for the facility.

The EMP (IT 1992) addressed activities such as rocket launches at KTF. Environmental monitoring of the 1994 STARS M-2 launch was consistent with requirements of the KTF EA (DOE 1992) and the STARS EIS (DOD 1992). A comprehensive monitoring program, similar in scope to the one implemented for the first STARS launch (FTU-1) on February 26, 1993, was conducted for the STARS M-2 except that no noise monitoring was performed.

As described in the STARS EIS, air samples were collected during the first demonstration launch (FTU-1) to validate the accuracy of the models used in the EIS and to evaluate compliance with federal and state standards. The instrumented monitoring program for the M2 launch, which included air quality, water, vegetation, and marine resources, was directed and coordinated by the U.S. Army Space and Strategic Defense Command (USASSDC) Environmental Office. All required state and federal agencies were contacted and sent results. The results showed that no adverse effects were caused by the launch and no federal or state standards were violated (DOD 1994). The Kauai Test Facility Mitigation Action Plan (Appendix D of the KTF EA [DOE 1992]) contains mitigation measures that are designed to reduce potential environmental impacts to minor levels. 


\section{H.4 OTHER COMPLIANCE ACTIVITIES}

\section{H.4.1 Spill Prevention Control and Countermeasure Plan}

SNL at KTF takes part in the PMRF Spill Prevention Control and Countermeasure (SPCC) Plan which provides support in the event of a diesel fuel spill from the 10,000-gallon (gal.) aboveground fuel tank inside the Main Compound (U.S. Navy 1991).

KTF has only one underground storage tank (UST) in its inventory (666C). This state-of-theart UST system was placed in service in August 1991 and is registered with the State of Hawaii as a DOE-owned SNL UST system.

\section{H.4.2 Toxic Substances Control Act}

Under the Toxic Substances Control Act (TSCA), oil-containing electrical and mechanical equipment and hydraulic fluid-containing systems must be assumed to be polychlorinated biphenyl (PCB) containing systems unless sampling and analysis show otherwise. The transformers on the KTF site have been tested and are free of PCBs. 
Table H-2. Individual Radiological Results for Soil Sampling at KTF in 1994

\begin{tabular}{|c|c|c|c|c|c|c|c|c|}
\hline Location & $\begin{array}{l}\text { Air Dry } \\
\text { Loss (\%) }\end{array}$ & $\underset{(\mu \mathrm{g} / \mathrm{g})}{\mathrm{U}_{\mathrm{tot}}}$ & $\begin{array}{l}\text { Gross Alpha } \\
(\mathrm{pCi} / \mathrm{g})\end{array}$ & $\begin{array}{c}\text { Gross Alpha } \\
\text { (pCi/g) } \\
\text { Error }\end{array}$ & $\begin{array}{l}\text { Gross Beta } \\
(\mathrm{pCi} / \mathrm{g})\end{array}$ & $\begin{array}{c}\text { Gross Beta } \\
\text { (pCi } / g) \\
\text { Error }\end{array}$ & $\begin{array}{l}\text { Cs-137 } \\
(\mathrm{pCi} / \mathrm{g})\end{array}$ & $\begin{array}{c}\text { Cs-137 } \\
\text { (pCi/g) } \\
\text { Error }\end{array}$ \\
\hline
\end{tabular}

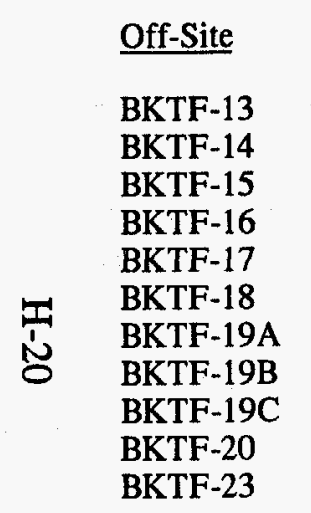

$\begin{array}{rl}<0.1 & 1.2 \\ 0.1 & 1.2 \\ 0.1 & 1.3 \\ <0.1 & 1.5 \\ <0.1 & 1.7 \\ <0.1 & 1.4 \\ <0.1 & 2.3 \\ <0.1 & 2.0 \\ <0.1 & 1.8 \\ <0.1 & 1.6 \\ 0.1 & 2.2\end{array}$

On-Site,

Main Compound

\begin{tabular}{|c|c|c|c|c|c|c|c|c|}
\hline MC-1 & 0.1 & 1.5 & 4 & 3 & 1 & 4 & ND & ND \\
\hline MC-2 & 0.1 & 1.8 & 5 & 3 & 2 & 4 & 0.04 & 0.02 \\
\hline MC-3 & 0.1 & 1.5 & 5 & 3 & -1 & 4 & 0.14 & 0.03 \\
\hline MC-4 & $<0.1$ & 1.6 & 1 & 3 & 3 & 4 & 0.04 & 0.02 \\
\hline MC-5 & 0.1 & 1.8 & 0 & 2 & 2 & 4 & ND & ND \\
\hline
\end{tabular}


Table H-2. Individual Radiological Results for Soil Sampling at KTF in 1994 (Concluded)

\begin{tabular}{|c|c|c|c|c|c|c|c|c|}
\hline Location & $\begin{array}{l}\text { Air Dry } \\
\text { Loss (\%) }\end{array}$ & $\begin{array}{c}\mathrm{U}_{\mathrm{tot}} \\
(\mu \mathrm{g} / \mathrm{g})\end{array}$ & $\begin{array}{l}\text { Gross Alpha } \\
\text { (pCi/g) }\end{array}$ & $\begin{array}{c}\text { Gross Alpha } \\
\text { (pCi/g) } \\
\text { Error }\end{array}$ & $\begin{array}{l}\text { Gross Beta } \\
(\mathrm{pCi} / \mathrm{g})\end{array}$ & $\begin{array}{c}\text { Gross Beta } \\
\text { (pCi/g) } \\
\text { Error }\end{array}$ & $\begin{array}{l}\mathrm{Cs}-137 \\
(\mathrm{pCi} / \mathrm{g})\end{array}$ & $\begin{array}{c}\text { Cs-137 } \\
\text { (pCi/g) } \\
\text { Error }\end{array}$ \\
\hline
\end{tabular}

Various Locations

\begin{tabular}{|c|c|c|c|c|c|c|c|c|}
\hline KTF-1 & 0.6 & 1.4 & 2 & 3 & 1 & 4 & 0.06 & 0.03 \\
\hline KTF-2 & 0.1 & 1.1 & 1 & 3 & 5 & 4 & 0.03 & 0.02 \\
\hline KTF-3 & 0.5 & 1.1 & 3 & 3 & 0 & 4 & 0.09 & 0.03 \\
\hline KTF-4 & 0.4 & 1.3 & 1 & 3 & 2 & 4 & 0.12 & 0.03 \\
\hline KTF-5 & 0.3 & 1.3 & 2 & 3 & 1 & 4 & ND & ND \\
\hline KTF-6 & 0.2 & 1.2 & 2 & 3 & 7 & 5 & 0.05 & 0.02 \\
\hline KTF-7 & 0.4 & 1.3 & -1 & 3 & 2 & 4 & 0.09 & 0.03 \\
\hline KTF-8 & 0.2 & 1.2 & 3 & 4 & -4 & 5 & ND & ND \\
\hline KTF-9 & 0.2 & 1.7 & 0 & 3 & 2 & 4 & ND & ND \\
\hline KTF-10A & 0.2 & 2.3 & 1 & 4 & 2 & 4 & ND & ND \\
\hline KTF-10B & 0.2 & 1.7 & 4 & 4 & -4 & 5 & ND & ND \\
\hline KTF-10C & 0.2 & 1.7 & -2 & 3 & 5 & 4 & ND & ND \\
\hline KTF-11 & 0.4 & 1.8 & -3 & 3 & 0 & 4 & ND & ND \\
\hline KTF-12 & 0.1 & 1.4 & 2 & 3 & -3 & 5 & ND & ND \\
\hline KTF-21 & $<0.1$ & 1.6 & -4 & 4 & 0 & 5 & ND & ND \\
\hline KTF-22 & $<0.1$ & 1.2 & 3 & 4 & 3 & 5 & ND & ND \\
\hline
\end{tabular}

Note: $\mu \mathrm{g} / \mathrm{g}=$ micrograms per gram; $\mathrm{pCi} / \mathrm{g}=$ picocuries per gram; $\mathrm{ND}=$ not detected. 
Table H-3. Individual Nonradiological Results (in $\mu \mathrm{g} / \mathrm{g}$ ) for Soil Sampling at KTF in 1994

\begin{tabular}{|c|c|c|c|c|c|c|c|c|c|c|c|}
\hline Location & $\begin{array}{l}\text { Aluminum } \\
\text { Total }\end{array}$ & $\begin{array}{c}\text { Barium } \\
\text { Total }\end{array}$ & $\begin{array}{l}\text { Beryllium } \\
\text { Total }\end{array}$ & $\begin{array}{l}\text { Cadmium } \\
\text { Total }\end{array}$ & $\begin{array}{l}\text { Calcium } \\
\text { Total }\end{array}$ & $\begin{array}{l}\text { Chromium } \\
\text { Total }\end{array}$ & $\begin{array}{c}\text { Cobalt } \\
\text { Total }\end{array}$ & $\begin{array}{c}\text { Copper } \\
\text { Total }\end{array}$ & $\begin{array}{l}\text { Iron } \\
\text { Total }\end{array}$ & $\begin{array}{l}\text { Lead } \\
\text { Total }\end{array}$ & $\begin{array}{c}\text { Magnesium } \\
\text { Total }\end{array}$ \\
\hline
\end{tabular}

\begin{tabular}{|c|c|c|c|c|c|c|c|c|c|c|c|}
\hline \multicolumn{12}{|c|}{ Off-Site } \\
\hline BKTF-13 & 7,500 & 8 & $<0.5$ & 0.7 & 180,000 & 86 & 30.0 & 14.0 & 22,000 & $<5$ & 52,000 \\
\hline BKTF-14 & 8,800 & 52 & $<0.5$ & 2.9 & 270,000 & 40 & 12.0 & 20.0 & 12,000 & $<5$ & 26,000 \\
\hline BKTF-15 & 6,400 & 14 & $<0.5$ & 4.2 & 220,000 & 67 & 23.0 & 17.0 & 18,000 & $<5$ & 43,000 \\
\hline BKTF-16 & 2,000 & $<5$ & $<0.5$ & 0.5 & 330,000 & 12 & 2.1 & 3.2 & 2,700 & $<5$ & 22,000 \\
\hline BKTF-17 & 3,600 & 10 & $<0.5$ & 1.8 & 300,000 & 37 & 9.8 & 4.9 & 8,700 & $<5$ & 32,000 \\
\hline BKTF-18 & 3,600 & 11 & $<0.5$ & 1.5 & 290,000 & 29 & 7.8 & 4.6 & 7,300 & $<5$ & 28,000 \\
\hline BKTF-19A & 1,500 & $<5$ & $<0.5$ & 1.5 & 300,000 & 32 & 8.7 & 2.2 & 6,900 & $<5$ & 33,000 \\
\hline BKTF-19B & 1,600 & $<5$ & $<0.5$ & $<0.5$ & 320,000 & 30 & 8.4 & 6.9 & 6,700 & $<5$ & 32,000 \\
\hline BKTF-19C & 1,500 & $<5$ & $<0.5$ & $<0.5$ & 320,000 & 32 & 8.8 & 2.8 & 6,800 & $<5$ & 32,000 \\
\hline BKTF-20 & 6,800 & 7 & $<0.5$ & $<0.5$ & 250,000 & 44 & 14.0 & 12.0 & 12,000 & $<5$ & 30,000 \\
\hline BKTF-23 & 6,800 & 12 & $<0.5$ & $<0.5$ & 320,000 & 46 & 6.8 & 8.5 & 8,100 & $<5$ & 18,000 \\
\hline \multicolumn{12}{|l|}{ On-Site, } \\
\hline MC-1 & 6,600 & 11 & $<0.5$ & 1.3 & 230,000 & 43 & 14.0 & 13 & 15,000 & $<5$ & 26,000 \\
\hline MC-2 & 7,100 & 31 & $<0.5$ & 1.1 & 220,000 & 58 & 16.0 & 22 & 20,000 & 110 & 28,000 \\
\hline MC-3 & 7,200 & 12 & $<0.5$ & 2.4 & 250,000 & 35 & 12.0 & 12 & 12,000 & $<5$ & 21,000 \\
\hline MC-4 & 6,500 & 6 & $<0.5$ & $<0.5$ & 230,000 & 39 & 13.0 & 9.8 & 13,000 & $<5$ & 26,000 \\
\hline MC-5 & 6,000 & 10 & $<0.5$ & $<0.5$ & 270,000 & 26 & 8.1 & 18 & 9,300 & $<5$ & 18,000 \\
\hline
\end{tabular}

Note: $\mu \mathrm{g} / \mathrm{g}=$ micrograms per gram; ICP $=$ inductively coupled plasma (method). 
Table H-3. Individual Nonradiological Results (in $\mu \mathrm{g} / \mathrm{g}$ ) for Soil Sampling at KTF in 1994 (Continued)

\begin{tabular}{|c|c|c|c|c|c|c|c|c|c|c|c|}
\hline Location & $\begin{array}{l}\text { Aluminum } \\
\text { Total }\end{array}$ & $\begin{array}{c}\text { Barium } \\
\text { Total }\end{array}$ & $\begin{array}{l}\text { Beryllium } \\
\text { Total }\end{array}$ & $\begin{array}{l}\text { Cadmium } \\
\text { Total }\end{array}$ & $\begin{array}{c}\text { Calcium } \\
\text { Total }\end{array}$ & $\begin{array}{c}\text { Chromium } \\
\text { Total }\end{array}$ & $\begin{array}{c}\text { Cobalt } \\
\text { Total }\end{array}$ & $\begin{array}{c}\text { Copper } \\
\text { Total }\end{array}$ & $\begin{array}{l}\text { Iron } \\
\text { Total }\end{array}$ & $\begin{array}{l}\text { Lead } \\
\text { Total }\end{array}$ & $\begin{array}{c}\text { Magnesium } \\
\text { Total }\end{array}$ \\
\hline
\end{tabular}

\section{Various Locations}

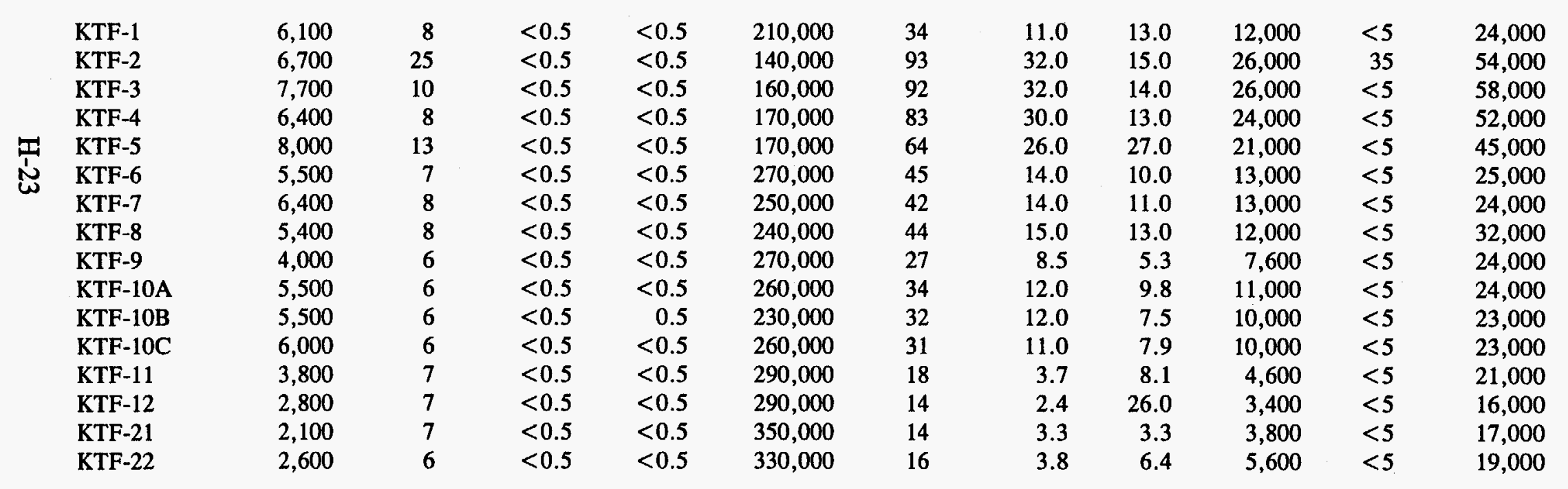

Note: $\mu \mathrm{g} / \mathrm{g}=$ micrograms per gram; ICP = inductively coupled plasma (method). 
Table H-3. Individual Nonradiological Results (in $\mu \mathrm{g} / \mathrm{g}$ ) for Soil Sampling at KTF in 1994 (Continued)

\begin{tabular}{|c|c|c|c|c|c|c|c|c|c|}
\hline Location & $\begin{array}{c}\text { Manganese } \\
\text { Total }\end{array}$ & $\begin{array}{l}\text { Nickel } \\
\text { Total }\end{array}$ & $\begin{array}{l}\text { Potassium } \\
\text { Total }\end{array}$ & $\begin{array}{c}\text { Silica-ICP } \\
\text { Total }\end{array}$ & $\begin{array}{c}\text { Silver } \\
\text { Total }\end{array}$ & $\begin{array}{l}\text { Strontium } \\
\text { Total }\end{array}$ & $\begin{array}{c}\text { Titanium } \\
\text { Total }\end{array}$ & $\begin{array}{l}\text { Vanadium } \\
\text { Total }\end{array}$ & $\begin{array}{l}\text { Zinc } \\
\text { Total }\end{array}$ \\
\hline
\end{tabular}

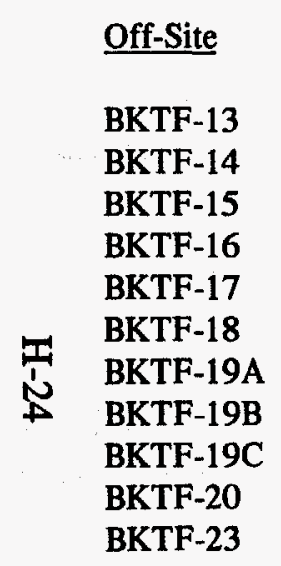

520
240
470
88
180
160
150
140
150
320
170

$\begin{array}{rr}520 & 430 \\ 97 & 780 \\ 310 & 500 \\ 21 & 110 \\ 130 & 60 \\ 94 & 110 \\ 130 & <50 \\ 120 & <50 \\ 120 & <50 \\ 160 & 250 \\ 55 & 690\end{array}$

460
1,900
150
190
520
1,100
140
200
290
580
34

$\begin{array}{ll}<0.5 & 2,000 \\ <0.5 & 2,300 \\ <0.5 & 2,100 \\ <0.5 & 2,400 \\ <0.5 & 2,600 \\ <0.5 & 2,500 \\ <0.5 & 2,800 \\ <0.5 & 2,800 \\ <0.5 & 2,800 \\ <0.5 & 2,400 \\ <0.5 & 2,600\end{array}$

$\begin{array}{ccr}640 & 27 & 35 \\ 910 & 25 & 24 \\ 540 & 26 & 30 \\ 160 & 7.9 & 14 \\ 330 & 12 & 11 \\ 330 & 12 & 10 \\ 120 & 7.2 & <10 \\ 130 & 6.9 & <10 \\ 130 & 7.1 & <10 \\ 520 & 21 & 26 \\ 440 & 18 & 26\end{array}$

On-Site,

Main Compound

\begin{tabular}{|c|c|c|c|c|c|c|c|c|}
\hline MC-1 & 290 & 140 & 210 & 780 & $<0.5$ & 2,900 & 590 & 23 \\
\hline MC-2 & 330 & 160 & 300 & 860 & $<0.5$ & 2,700 & 670 & 24 \\
\hline MC-3 & 260 & 97 & 190 & 680 & $<0.5$ & 3,100 & 560 & 21 \\
\hline MC-4 & 260 & 140 & 220 & 950 & $<0.5$ & 2,900 & 530 & 22 \\
\hline MC-5 & 220 & 71 & 150 & 340 & $<0.5$ & 3,100 & 560 & 20 \\
\hline
\end{tabular}

Note: $\mu \mathrm{g} / \mathrm{g}=$ micrograms per gram; ICP = inductively coupled plasma (method). 
Table H-3. Individual Nonradiological Results (in $\mu \mathrm{g} / \mathrm{g}$ ) for Soil Sampling at KTF in 1994 (Concluded)

\begin{tabular}{ccccccccc}
\hline & Manganese & Nickel & Potassium & Silica-ICP & Silver & Strontium & Titanium \\
Location & Total & Total & Total & Total & Total & $\begin{array}{c}\text { Vanadium } \\
\text { Total }\end{array}$ & $\begin{array}{c}\text { Zinc } \\
\text { Total }\end{array}$ & $\begin{array}{c}\text { Total } \\
\text { Total }\end{array}$ \\
\hline
\end{tabular}

Various Locations

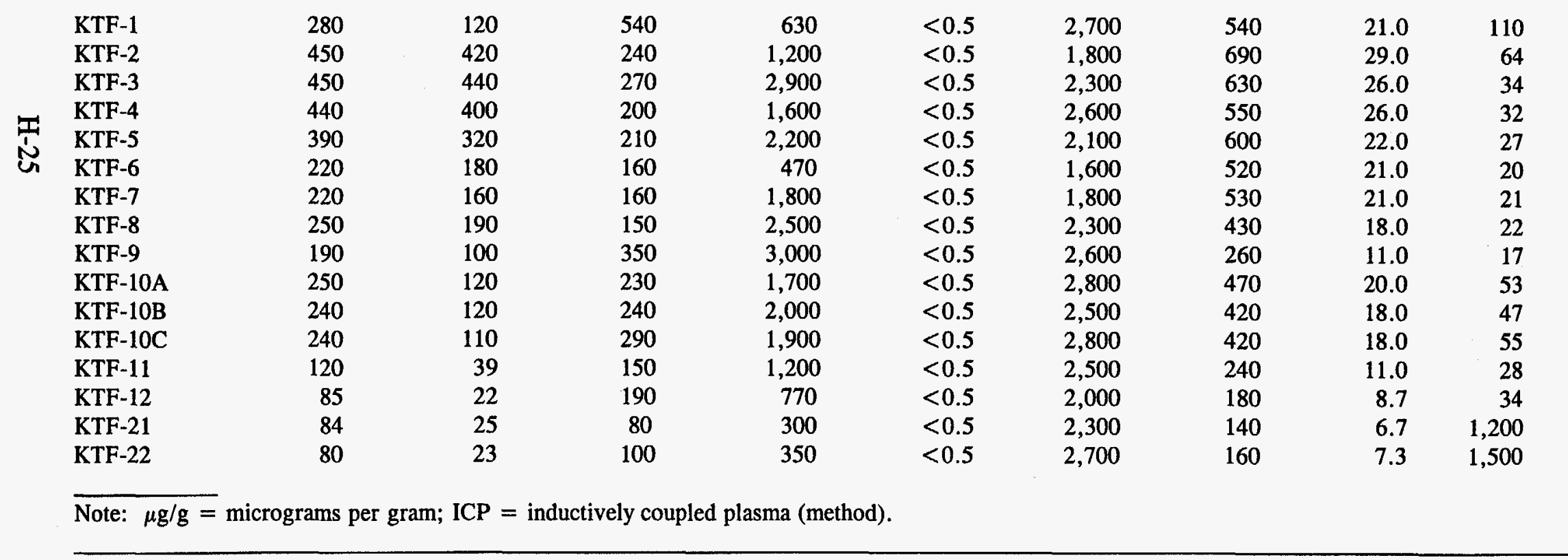


Table H-4. Results of Replicate Sampling (in $\mu \mathrm{g} / \mathrm{g}$ )

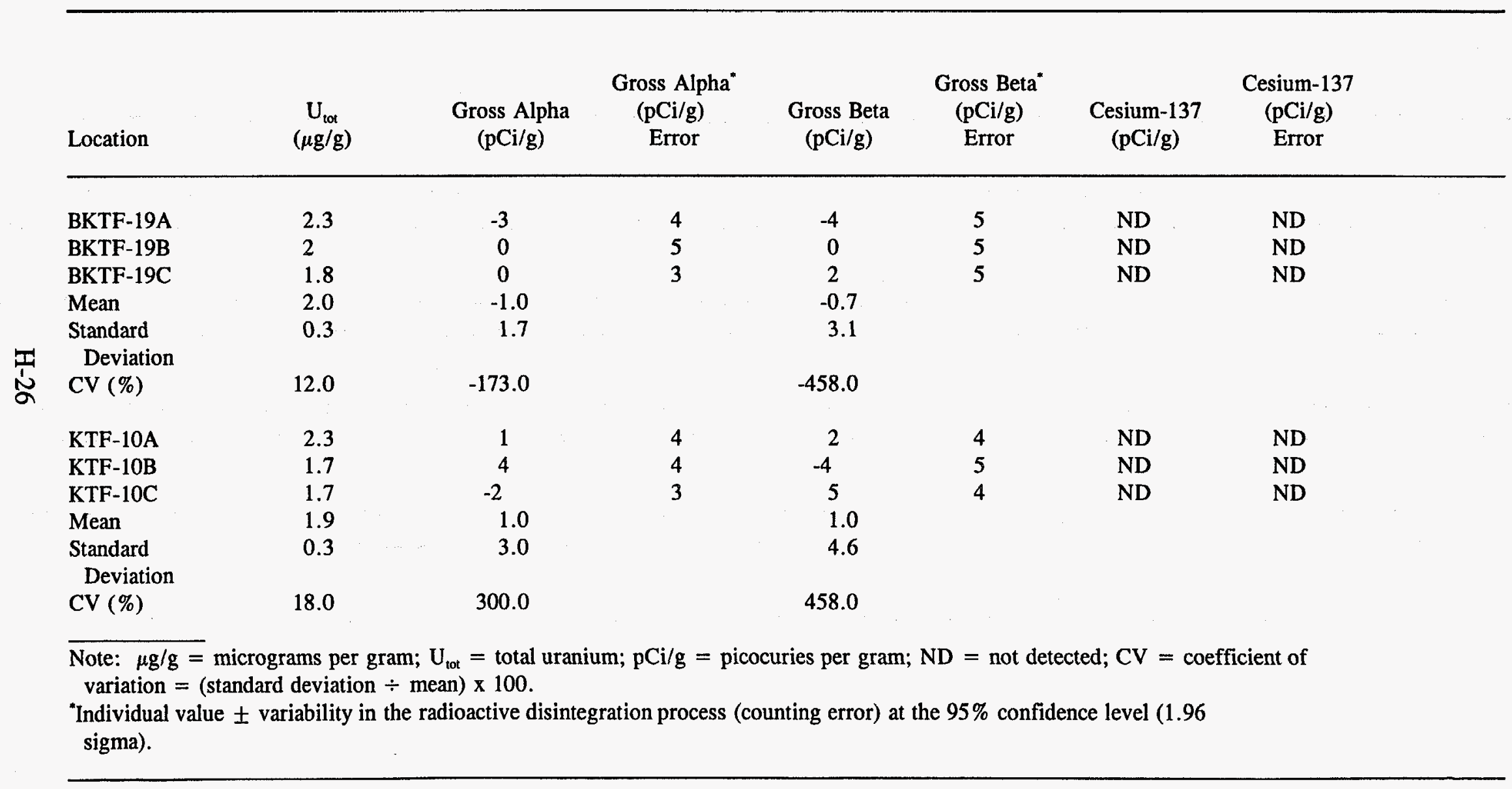


Table H-4. Results of Replicate Sampling (in $\mu \mathrm{g} / \mathrm{g}$ ) (Continued)

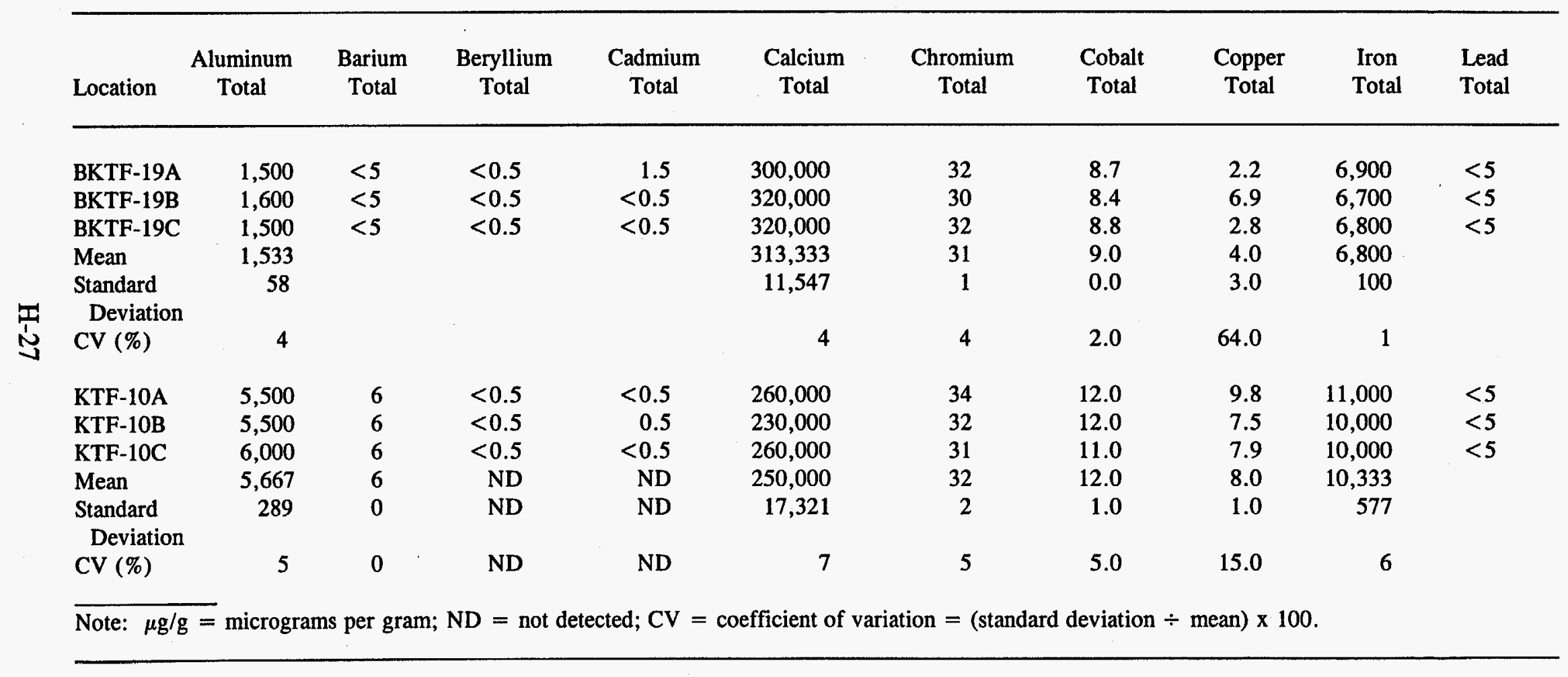


Table H-4. Results of Replicate Sampling (in $\mu \mathrm{g} / \mathrm{g}$ ) (Concluded)

\begin{tabular}{|c|c|c|c|c|c|c|c|c|c|c|}
\hline Location & $\begin{array}{c}\text { Magnesium } \\
\text { Total }\end{array}$ & $\begin{array}{c}\text { Manganese } \\
\text { Total }\end{array}$ & $\begin{array}{c}\text { Nickel } \\
\text { Total }\end{array}$ & $\begin{array}{l}\text { Potassium } \\
\text { Total }\end{array}$ & $\begin{array}{c}\text { Silica-ICP } \\
\text { Total }\end{array}$ & $\begin{array}{l}\text { Silver } \\
\text { Total }\end{array}$ & $\begin{array}{l}\text { Strontium } \\
\text { Total }\end{array}$ & $\begin{array}{c}\text { Titanium } \\
\text { Total }\end{array}$ & $\begin{array}{c}\text { Vanadium } \\
\text { Total }\end{array}$ & $\begin{array}{l}\text { Zinc } \\
\text { Total }\end{array}$ \\
\hline BKTF-19B & 32,000 & 140 & 120 & $<50$ & 200 & $<0.5$ & 2,800 & 130 & 6.9 & $<10$ \\
\hline BKTF-19C & 32,000 & 150 & 120 & $<50$ & 290 & $<0.5$ & 2,800 & 130 & 7.1 & $<10$ \\
\hline CV (\%) & 2 & 4 & 5 & & 36 & & 0 & 5 & 2 & \\
\hline KTF-10A & 24,000 & 250 & 120 & 230 & 1,700 & $<0.5$ & 2,800 & 470 & 20 & 53 \\
\hline KTF-10B & 23,000 & 240 & 120 & 240 & 2,000 & $<0.5$ & 2,500 & 420 & 18 & 47 \\
\hline KTF-10C & 23,000 & 240 & 110 & 290 & 1,900 & $<0.5$ & 2,800 & 420 & 18 & 55 \\
\hline
\end{tabular}

Note: $\mu \mathrm{g} / \mathrm{g}=$ micrograms per gram; ICP $=$ inductively coupled plasma (method); ND $=$ not detected; $\mathrm{CV}=$ coefficient of variation $=($ standard deviation $\div$ mean) $\times 100$. 
Table H-5. Summary of Radiological Data for Soil Samples Collected at KTF in 1994

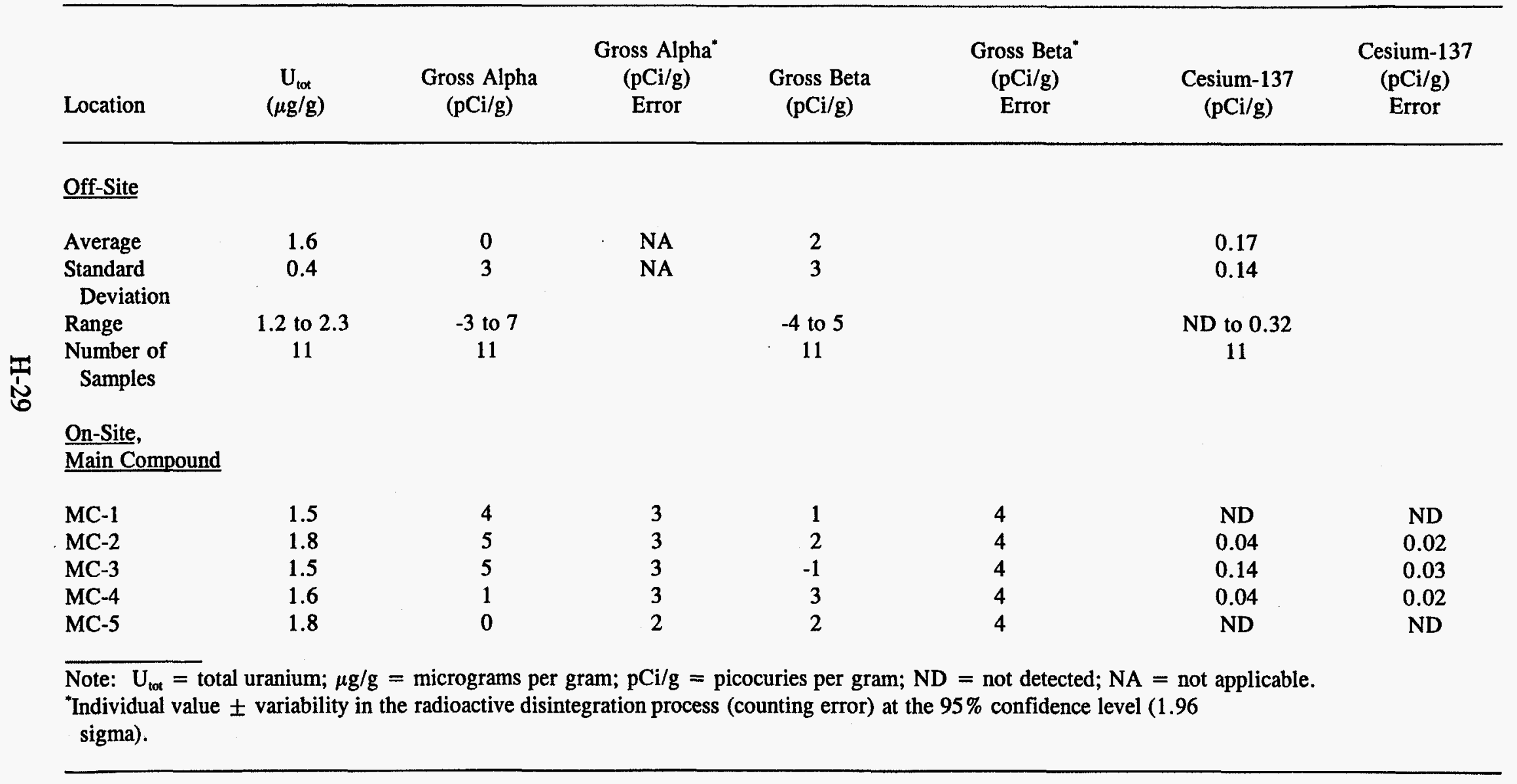


Table H-5. Summary of Radiological Data for Soil Samples Collected at KTF in 1994 (Concluded)

\begin{tabular}{|c|c|c|c|c|c|c|c|}
\hline Location & $\underset{(\mu \mathrm{g} / \mathrm{g})}{\mathrm{U}_{\mathrm{ta}}}$ & $\begin{array}{l}\text { Gross Alpha } \\
\text { (pCi/g) }\end{array}$ & $\begin{array}{c}\text { Gross Alpha* } \\
\text { (pCi/g) } \\
\text { Error }\end{array}$ & $\begin{array}{l}\text { Gross Beta } \\
(\mathrm{pCi} / \mathrm{g})\end{array}$ & $\begin{array}{c}\text { Gross Beta* } \\
\text { (pCi/g) } \\
\text { Error }\end{array}$ & $\begin{array}{l}\text { Cesium-137 } \\
(\mathrm{pCi} / \mathrm{g})\end{array}$ & $\begin{array}{c}\text { Cesium-137 } \\
\text { (pCi/g) } \\
\text { Error }\end{array}$ \\
\hline
\end{tabular}

\section{Various Locations}

\begin{tabular}{|c|c|c|c|c|c|c|c|}
\hline KTF-1 & 1.4 & 2 & 3 & 1 & 4 & 0.06 & 0.03 \\
\hline KTF-2 & 1.1 & 1 & 3 & 5 & 4 & 0.03 & 0.02 \\
\hline KTF-3 & 1.1 & 3 & 3 & 0 & 4 & 0.09 & 0.03 \\
\hline KTF-4 & 1.3 & 1 & 3 & 2 & 4 & 0.12 & 0.03 \\
\hline KTF-5 & 1.3 & 2 & 3 & 1 & 4 & ND & ND \\
\hline KTF-6 & 1.2 & 2 & 3 & 7 & 5 & 0.05 & 0.02 \\
\hline KTF-7 & 1.3 & -1 & 3 & 2 & 4 & 0.09 & 0.03 \\
\hline KTF-8 & 1.2 & 3 & 4 & -4 & 5 & ND & ND \\
\hline KTF-9 & 1.7 & 0 & 3 & 2 & 4 & ND & ND \\
\hline KTF-10A & 2.3 & 1 & 4 & 2 & 4 & ND & ND \\
\hline KTF-11 & 1.8 & -3 & 3 & 0 & 4 & ND & ND \\
\hline PAD-1 & 1.4 & 2 & 3 & -3 & 5 & ND & ND \\
\hline
\end{tabular}

Note: $\mathrm{U}_{\text {tot }}=$ total uranium; $\mu \mathrm{g} / \mathrm{g}=$ micrograms per gram; $\mathrm{pCi} / \mathrm{g}$ - picocuries per gram; ND $=$ not detected.

"Individual value \pm variability in the radioactive disintegration process (counting error) at the $95 \%$ confidence level (1.96 sigma). 
Table H-6. Summary of Nonradiological Data (in $\mu \mathrm{g} / \mathrm{g}$ ) for Soil Samples Collected at KTF in 1994

\begin{tabular}{|c|c|c|c|c|c|c|c|c|c|c|}
\hline Location & $\begin{array}{c}\text { Aluminum } \\
\text { Total }\end{array}$ & $\begin{array}{l}\text { Barium } \\
\text { Total }\end{array}$ & $\begin{array}{l}\text { Beryllium } \\
\text { Total }\end{array}$ & $\begin{array}{l}\text { Cadmium } \\
\text { Total }\end{array}$ & $\begin{array}{l}\text { Calcium } \\
\text { Total }\end{array}$ & $\begin{array}{l}\text { Chromium } \\
\text { Total }\end{array}$ & $\begin{array}{l}\text { Cobalt } \\
\text { Total }\end{array}$ & $\begin{array}{c}\text { Copper } \\
\text { Total }\end{array}$ & $\begin{array}{l}\text { Iron } \\
\text { Total }\end{array}$ & $\begin{array}{l}\text { Lead } \\
\text { Total }\end{array}$ \\
\hline \multicolumn{11}{|l|}{ Off-Site } \\
\hline Average & 5,200 & 8 & $<0.5$ & 1.60 & 273,000 & 44 & 13 & 9.6 & 11,000 & $<0.5$ \\
\hline $\begin{array}{l}\text { Standard } \\
\text { Deviation }\end{array}$ & 2,600 & 3 & ND & 1.3 & 49,000 & 22 & 9 & 6.4 & 6,000 & ND \\
\hline Range & $\begin{array}{c}1,500 \text { to } \\
8,000\end{array}$ & $\begin{array}{l}<5 \text { to } \\
148\end{array}$ & $\begin{array}{l}<0.5 \text { to } \\
<0.5\end{array}$ & $\begin{array}{c}<0.5 \text { to } \\
4.2\end{array}$ & $\begin{array}{c}180,000 \text { to } \\
330,000\end{array}$ & $\begin{array}{l}50 \text { to } \\
86\end{array}$ & $\begin{array}{l}2 \text { to } \\
30\end{array}$ & $\begin{array}{l}2.2 \text { to } \\
20.0\end{array}$ & $\begin{array}{c}2,7000 \text { to } \\
22,000\end{array}$ & $\begin{array}{l}<0.5 \text { to } \\
<0.5\end{array}$ \\
\hline $\begin{array}{c}\text { Number of } \\
\text { Samples }\end{array}$ & 9 & 9 & 9 & 9 & 9 & 9 & 9 & 9 & 9 & 9 \\
\hline \multicolumn{11}{|c|}{$\begin{array}{l}\text { On-Site, } \\
\text { Main Compound }\end{array}$} \\
\hline MC-1 & 6,600 & 11 & $<0.5$ & 1.3 & 230,000 & 43 & 14.0 & 13.0 & 15,000 & $<5$ \\
\hline MC-2 & 7,100 & 31 & $<0.5$ & 1.1 & 220,000 & 58 & 16.0 & 22.0 & 20,000 & 110 \\
\hline MC-3 & 7,200 & 12 & $<0.5$ & 2.4 & 250,000 & 35 & 12.0 & 12.0 & 12,000 & $<5$ \\
\hline MC-4 & 6,500 & 6 & $<0.5$ & $<0.5$ & 230,000 & 39 & 13.0 & 9.8 & 13,000 & $<5$ \\
\hline MC-5 & 6,000 & 10 & $<0.5$ & $<0.5$ & 270,000 & 26 & 8.1 & 18.0 & 9,300 & $<5$ \\
\hline
\end{tabular}


Table H-6. Summary of Nonradiological Data (in $\mu \mathrm{g} / \mathrm{g}$ ) for Soil Samples Collected at KTF in 1994 (Continued)

\begin{tabular}{|c|c|c|c|c|c|c|c|c|c|c|}
\hline Location & $\begin{array}{l}\text { Magnesium } \\
\text { Total }\end{array}$ & $\begin{array}{c}\text { Manganese } \\
\text { Total }\end{array}$ & $\begin{array}{c}\text { Nickel } \\
\text { Total }\end{array}$ & $\begin{array}{l}\text { Potassium } \\
\text { Total }\end{array}$ & $\begin{array}{c}\text { Silica-ICP } \\
\text { Total }\end{array}$ & $\begin{array}{c}\text { Silver } \\
\text { Total }\end{array}$ & $\begin{array}{l}\text { Strontium } \\
\text { Total }\end{array}$ & $\begin{array}{c}\text { Titanium } \\
\text { Total }\end{array}$ & $\begin{array}{c}\text { Vanadium } \\
\text { Total }\end{array}$ & $\begin{array}{l}\text { Zinc } \\
\text { Total }\end{array}$ \\
\hline
\end{tabular}

Off-Site

\begin{tabular}{|c|c|c|c|c|c|c|c|c|c|c|}
\hline Average & 32,000 & 260 & 98 & 330 & 397 & $<0.5$ & 2,400 & 440 & 17 & 21 \\
\hline $\begin{array}{l}\text { Standard } \\
\text { Deviation }\end{array}$ & 10,000 & 150 & 48 & 280 & 348 & ND & 250 & 250 & 8 & 10 \\
\hline Range & $\begin{array}{c}18,000 \text { to } \\
52,000\end{array}$ & $\begin{array}{c}88 \text { to } \\
520\end{array}$ & $\begin{array}{c}21 \text { to } \\
160\end{array}$ & $\begin{array}{l}50 \text { to } \\
780\end{array}$ & $\begin{array}{l}34 \text { to } \\
1,100\end{array}$ & $\begin{array}{c}<0.5 \text { to } \\
<0.5\end{array}$ & $\begin{array}{c}2,000 \text { to } \\
2,800\end{array}$ & $\begin{array}{c}120 \text { to } \\
910\end{array}$ & $\begin{array}{l}7 \text { to } \\
27\end{array}$ & $\begin{array}{c}10 \text { to } \\
35\end{array}$ \\
\hline $\begin{array}{l}\text { Number of } \\
\text { Samples }\end{array}$ & 9 & 9 & 7 & 9 & 9 & 9 & 9 & 9 & 9 & 9 \\
\hline \multicolumn{11}{|c|}{$\begin{array}{l}\text { On-Site, } \\
\text { Main Compound }\end{array}$} \\
\hline MC-1 & 26,000 & 290 & 140 & 210 & 780 & $<0.5$ & 2,900 & 590 & 23 & 290 \\
\hline MC-2 & 28,000 & 330 & 160 & 300 & 860 & $<0.5$ & 2,700 & 670 & 24 & 390 \\
\hline MC-3 & 21,000 & 260 & 97 & 190 & 680 & $<0.5$ & 3,100 & 560 & 21 & 660 \\
\hline MC-4 & 26,000 & 260 & 140 & 220 & 950 & $<0.5$ & 2,900 & 530 & 22 & 210 \\
\hline MC-5 & 18,000 & 220 & 71 & 150 & 340 & $<0.5$ & 3,100 & 560 & 20 & 35 \\
\hline
\end{tabular}

Note: $\mu \mathrm{g} / \mathrm{g}=$ micrograms per gram; $\mathrm{ND}=$ not detected; $\mathrm{ICP}=$ inductively coupled plasma (method). 
Table H-6. Summary of Nonradiological Data (in $\mu \mathrm{g} / \mathrm{g}$ ) for Soil Samples Collected at KTF in 1994 (Continued)

\begin{tabular}{|c|c|c|c|c|c|c|c|c|c|c|}
\hline Location & $\begin{array}{l}\text { Aluminum } \\
\text { Total }\end{array}$ & $\begin{array}{c}\text { Barium } \\
\text { Total }\end{array}$ & $\begin{array}{l}\text { Beryllium } \\
\text { Total }\end{array}$ & $\begin{array}{l}\text { Cadmium } \\
\text { Total }\end{array}$ & $\begin{array}{l}\text { Calcium } \\
\text { Total }\end{array}$ & $\begin{array}{c}\text { Chromium } \\
\text { Total }\end{array}$ & $\begin{array}{l}\text { Cobalt } \\
\text { Total }\end{array}$ & $\begin{array}{c}\text { Copper } \\
\text { Total }\end{array}$ & $\begin{array}{l}\text { Iron } \\
\text { Total }\end{array}$ & $\begin{array}{l}\text { Lead } \\
\text { Total }\end{array}$ \\
\hline
\end{tabular}

\section{$\underline{\text { Various Locations }}$}

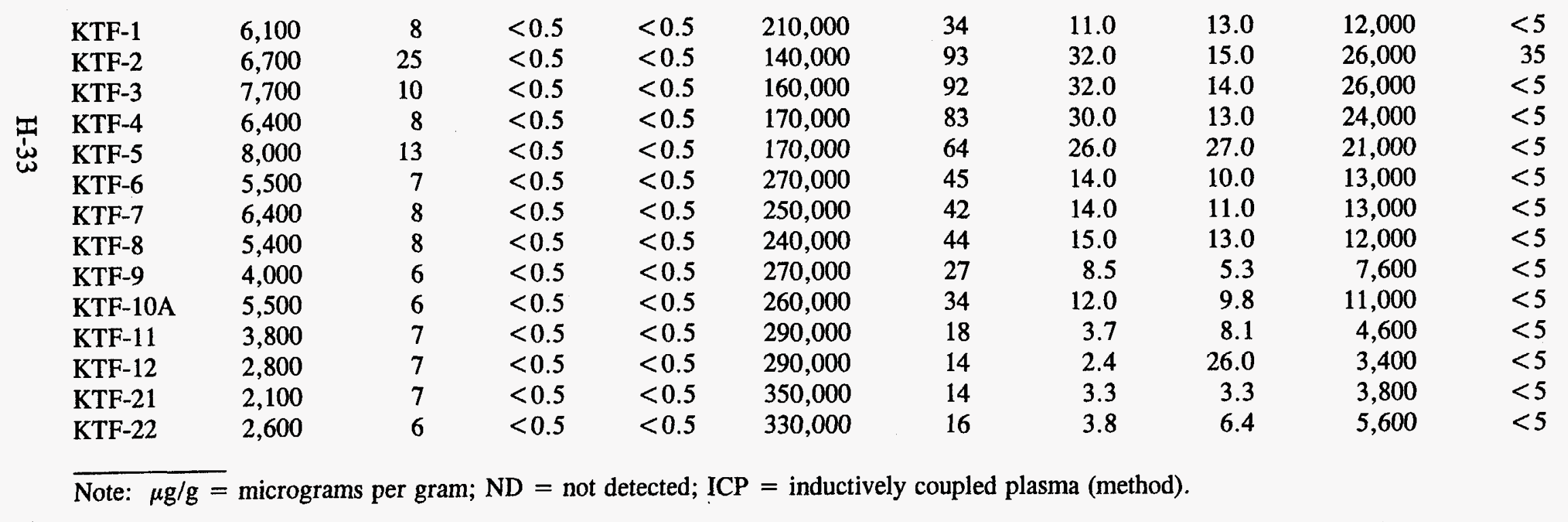


Table H-6. Summary of Nonradiological Data (in $\mu \mathrm{g} / \mathrm{g}$ ) for Soil Samples Collected at KTF in 1994 (Concluded)

\begin{tabular}{|c|c|c|c|c|c|c|c|c|c|c|}
\hline Location & $\begin{array}{l}\text { Magnesium } \\
\text { Total }\end{array}$ & $\begin{array}{c}\text { Manganese } \\
\text { Total }\end{array}$ & $\begin{array}{l}\text { Nickel } \\
\text { Total }\end{array}$ & $\begin{array}{l}\text { Potassium } \\
\text { Total }\end{array}$ & $\begin{array}{l}\text { Silica-ICP } \\
\text { Total }\end{array}$ & $\begin{array}{l}\text { Silver } \\
\text { Total }\end{array}$ & $\begin{array}{l}\text { Strontium } \\
\text { Total }\end{array}$ & $\begin{array}{l}\text { Titanium } \\
\text { Total }\end{array}$ & $\begin{array}{l}\text { Vanadium } \\
\text { Total }\end{array}$ & $\begin{array}{l}\text { Zinc } \\
\text { Total }\end{array}$ \\
\hline
\end{tabular}

Various Locations

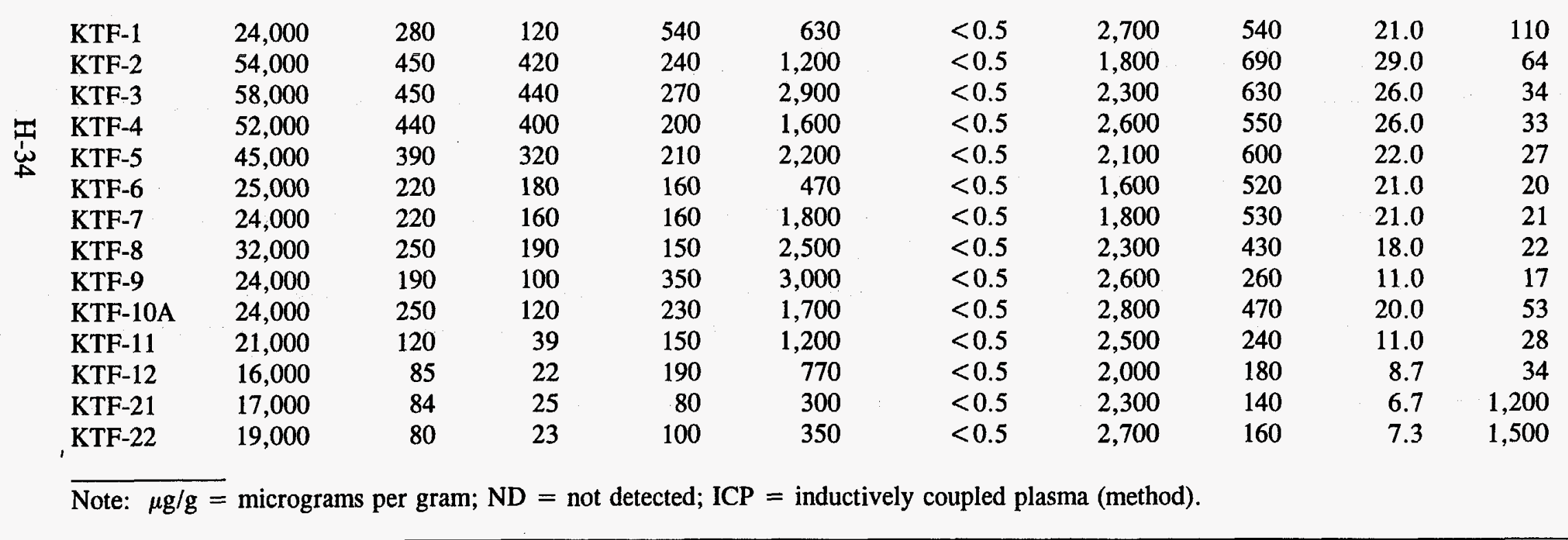




\section{REFERENCES}

DOD 1994: U.S. Department of Defense, "Ambient Air Quality Assessment No. 43-21N3DD-94, Strategic Target System, Operational and Deployment Experiments Simulator Missile Launch, Pacific Missile Range Facility, Kauai Test Facility, Barking Sands, Kauai, Hawaii, 6-25 July 1994," U.S. Army Environmental Hygiene Agency, Department of Defense.

DOD 1992: "Final Environmental Impact Statement for the Strategic Target System," Volumes I through III, U.S. Army Strategic Defense Command, Department of Defense (May 1992).

Comprehensive Environmental Reponse, Compensation and Liability Act (CERCLA) of 1980, as amended. Title 40 U.S.C. 9601.

DOE 1988: U.S. Department of Energy, "General Environmental Protection Program," DOE Order 5400.1, DOE, Washington, DC (1988; change 1, June 21, 1990).

DOE 1992: U.S. Department of Energy Albuquerque Operations Office (DOE/AL), "Kauai Test Facility Environmental Assessment, " DOE/EA-0492, DOE/AL, Albuquerque, NM (1992).

Gonzalez and Berryman 1990: Gonzalez, T., and J. Berryman, "Archaeological Survey and Testing, Department of Energy, Kauai Test Facility," prepared for Sandia National Laboratories, Albuquerque, NM (1990).

Helgesen 1990: Helgesen, R. F., "Safety Assessment for the Kauai Test Facility at Barking Sands, Kauai, " SAND89-2548, Sandia National Laboratories, Albuquerque, NM (1990).

IT 1990a: IT Corporation, "A Survey of the Green Sea Turtle Population Fronting the Kauai Test Facility, Pacific Missile Range, Barking Sands, Kauai: An Analysis of Potential Impacts with Implementation of the Strategic Defense Initiative" prepared for Sandia National Laboratories, Albuquerque, NM (1990).

IT 1990b: IT Corporation, "Botanical Survey of the Kauai Test Facility Site, Barking Sands, Kauai, Hawaii, " prepared for Sandia National Laboratories, Albuquerque, NM (1990).

IT 1990c: IT Corporation, "Ornithological Survey Report of the Kauai Test Facility Site, Barking Sands, Kauai, Hawaii," prepared for Sandia National Laboratories, Albuquerque, NM (1990). 
IT 1990d: IT Corporation, "Soil Sampling Program for Sandia National Laboratories, Kauai Test Facility, Kauai, Hawaii," prepared for Sandia National Laboratories, Albuquerque, NM (1990).

IT 1992: IT Corporation, "Sandia National Laboratories Kauai Test Facility Environmental Monitoring Plan, " prepared for Sandia National Laboratories, Albuquerque, NM (1992).

SNL 1986: Sandia National Laboratories, "Environmental Report, Proposed IRBS Facilities, Kauai Test Facility, " prepared by Sandia National Laboratories, Albuquerque, NM, for the DOE (1986).

SNL 1992: Sandia National Laboratories, "Environmental Sampling Procedure," SP471991, Sandia National Laboratories, Albuquerque, NM (November 19, 1992).

Superfund Amendments and Reauthorization Act (SARA) of 1986. Title III, Section 313, "Toxic Chemical Release Reporting."

Toxic Substances Control Act (TSCA) of 1976. U.S.C. \$2601 et seq.

U.S. Navy 1991: U.S. Navy, "Spill Prevention Control and Countermeasure Plan, Pacific Missile Range Facility," Pacific Division, Naval Facilities Engineering Command, Pearl Harbor, HI (February 1991). 
U.S. Department of Energy (80)

Kirtland Area Office (KAO)

Environment, Safety, Health, and Compliance Branch

P.O. Box 5400

Albuquerque, NM 87185

U.S. Department of Energy/HQ, (3) Office of Environmental Policy and Assistance (EH-41)

1000 Independence Ave. SW

Washington, DC 20585

U.S. Department of Energy/HQ, (2)

Office of Research, Development and Testing Facilities (DP-13)

1000 Independence Ave. SW

Washington, DC 20585

U.S. Department of Energy/HQ, (1)

Office of Environmental

Oversight (EM-22)

1000 Independence Ave. SW

Washington, DC 20585

U.S. Department of Energy/HQ, (2)

Office of Southwestern Area

Programs (EM-45)

1000 Independence Ave. SW

U.S. Department of Energy (3)

Albuquerque Operations Office, EPD

P.O. Box 5400

Albuquerque, NM 87185-5400

New Mexico Environment Department (1)

c/o DOE-KAO-ESHCB

P.O. Box 5400

Albuquerque, NM 87185-5400

Albuquerque City Environmental

Services (1)

400 Marquette Ave. NW

Albuquerque, NM 87117
Captain Robert C. Viramontes (1)

2000 Wyoming Blvd.

377 ABW/EMP

KAFB, NM 87117-5606

Director (1)

Inhalation Toxicology Research Institute P.O. Box 5800

Albuquerque, NM 87185

Environmental Protection Agency (1)

Headquarters Office

401 M Street, SW

Washington, DC 20460

Environmental Protection Agency (1)

Region VI Office

1445 Ross Ave.

Dallas, TX 75202-2733 


\section{SANDIA NATIONAL LABORATORIES, INTERNAL DISTRIBUTION}

5 (MS 0100) Document Processing, 7613-2 for DOE/OSTI

1 (MS 0141) C. B. Hall, 11300

1 (MS 0141) R. J. Park, 11300

1 (MS 0141) T. A. Vandenberg, 11300

1 (MS 0167) K. Kuhlmann, 12621

1 (MS 0167) A. Stotts, 12630

1 (MS 0407) P. Yourick, 7311

1 (MS 0617) G. L. West, 2701

1 (MS 0619) Print Media, 12615

1 (MS 0651) J. A. Pigg, 7711

1 (MS 0658) R. G. Hay, 2723

1 (MS 0658) C. Nelson, 9819-1

1 (MS 0875) A. O. Bendure, 7258

1 (MS 0875) D. Finnegan, 7313

2 (MS 0875) T. A. Wolff, 7258

5 (MS 0899) Technical Library, 13414

1 (MS 1064) J. Lewis, 7001

1 (MS 1067) A. N. Blackwell, 7000

1 (MS 1067) G. E. Chavez, 7002

1 (MS 1303) J. R. Guth, 7573

1 (MS 1305) N. A. Durand, 7576

1 (MS 1305) J. A. Fernandez, 7574

1 (MS 1307) B. A. Botsford, 7577

1 (MS 1307) J. G. Yeager, 7572

35 (MS 1309) Records Center and 7500 Library, 7512

1 (MS 1310) E. Conway, 7571

2 (MS 1311) T. A. Culp, 7575

1 (MS 1311) H. A. Hwang, 7575

7 (MS 1311) R. Sanchez, 7575

2 (MS 1311) L. J. Shyr, 7575

1 (MS 1311) S. J. Ward, 7511

1 (MS 1315) T. E. Blejwas, 7500

1 (MS 1315) D. Rohde, 7501

1 (MS 1347) W. B. Cox, 7581

1 (MS 1347) F. B. Nimick, 7582

1 (MS 1331) B. Jenkins, 7513

1 (MS 1348) A. Maese, 7512

1 (MS 1350) F. Lauffer, 7584

1 (MS 1350) D. L. Stermer, 7584

1 (MS 9018) Central Technical Files, 8523-2 